Portland State University

PDXScholar

5-4-1995

\title{
A Hydrologic Analysis of Government Island, Oregon
}

Scott Gregory Bittinger

Portland State University

Follow this and additional works at: https://pdxscholar.library.pdx.edu/open_access_etds

Part of the Geology Commons

Let us know how access to this document benefits you.

Recommended Citation

Bittinger, Scott Gregory, "A Hydrologic Analysis of Government Island, Oregon" (1995). Dissertations and Theses. Paper 4851.

https://doi.org/10.15760/etd.6727

This Thesis is brought to you for free and open access. It has been accepted for inclusion in Dissertations and Theses by an authorized administrator of PDXScholar. Please contact us if we can make this document more accessible: pdxscholar@pdx.edu. 
An abstract and thesis of scott Gregory Bittinger for the Master of Science in Geology presented May 4, 1995 and accepted by the thesis committee and the department.

COMMITTEE APPROVALS :
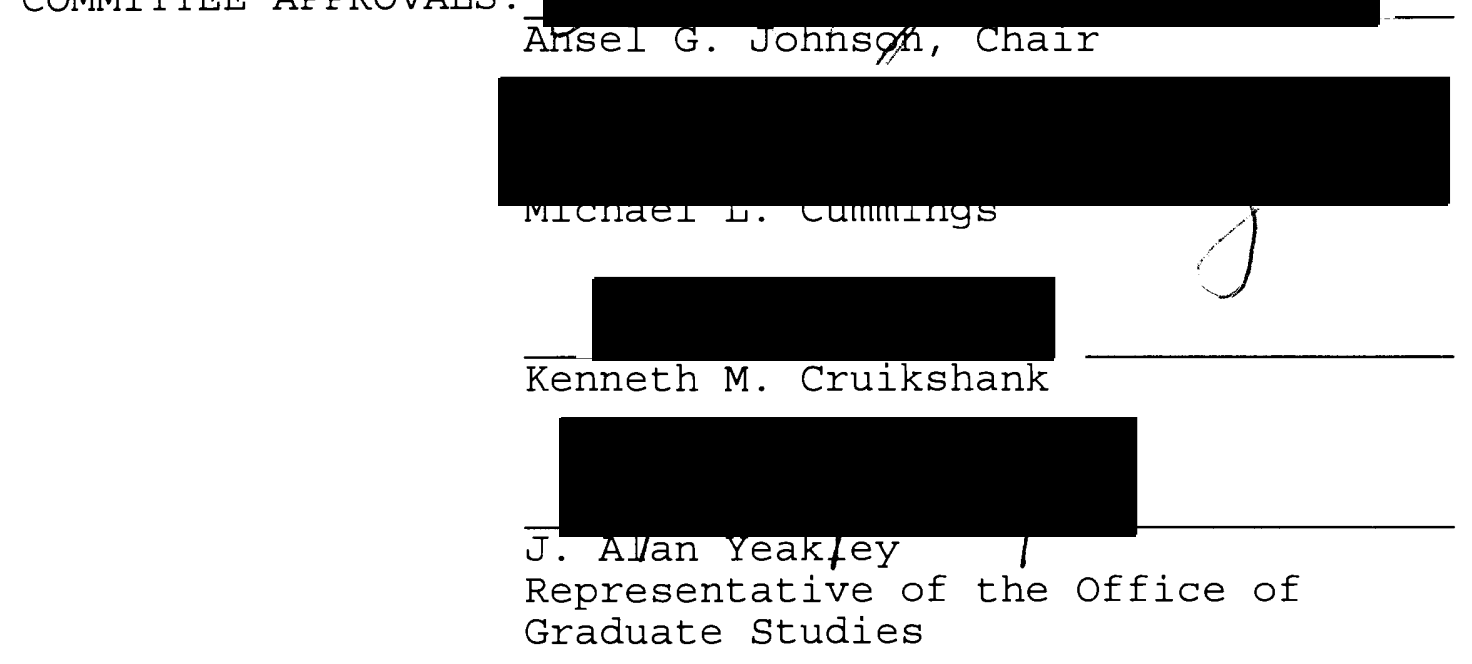

DEPARTMENT APPROVAL

yarvin H. Beeson, chair

(Department of Geology

ACCEPTED FOR PORTLAND STATE UNIVERSITY BY THE LIBRARY

by
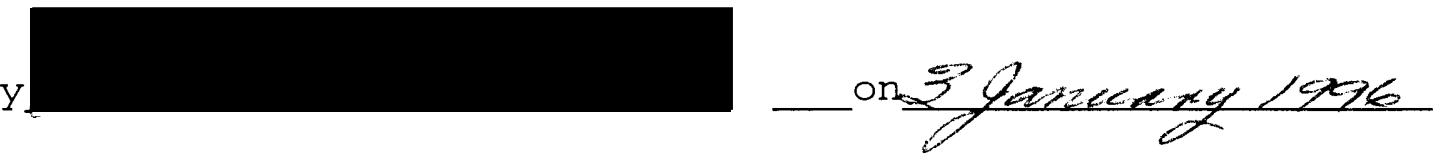


\section{ABSTRACT}

An abstract of the thesis of Scott Gregory Bittinger for the Master of Science in Geology presented May 4, 1995.

Title: A Hydrologic Analysis of Government Island, Oregon.

Government Island, located in the Columbia River approximately $16 \mathrm{~km}$ (10 $\mathrm{mi})$ upstream of the confluence with the Willamette River, is a wetland mitigation site prompted by expansion of the southwest quadrant of Portland International Airport. The purpose of the study is to predict water levels in two enclosed lowland areas, Jewit Lake and Southeast Pond, based on levels of the Columbia River, precipitation, and evapotranspiration. Mitigation is intended to convert $1.13 \mathrm{~km}^{2}$ (237 acres) of seasonally flooded wetland to $1.27 \mathrm{~km}^{2}$ (267 acres) of semi-permanently flooded wetland and seasonally flooded wetland.

Flooding of the wetland is most likely to occur December through January and May through early June when Columbia River water levels at Government Island exceed

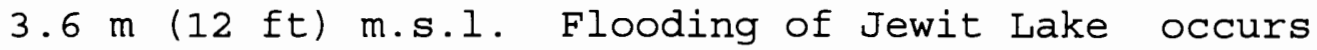
through a channel connecting the wetland to the columbia River.

A groundwater model (MODFLOW) was parameterized to 
simulate the hydrology of the wetland. Observations of the subsurface stratigraphy in 25 soil pits, bucket auger cores, and during installation of water monitoring devices were used to estimate thickness and lateral extent of a confining unit that overlies an aquifer. Climatological data for 1994 and water levels were entered into MODFLOW to calibrate rates of water movement through the subsurface. Periods of drying for Jewit Lake and Southeast Pond were predicted based on precipitation and actual evapotranspiration rates expected to be present in the study area between June and December.

Results of groundwater modeling show that Jewit Lake will maintain surface water above $3.6 \mathrm{~m}$ (12 ft) in most years. Southeast Pond is expected to dry annually as mitigation is unlikely to change the hydrology of Southeast Pond.

Groundwater modeling predicted the types of wetlands present at different elevations by evaluating periods of drying within the wetland using the U.S. Fish and Wildlife Service classification of wetlands method. Results suggest that Jewit Lake will be converted to semipermanently flooded wetland below $3.6 \mathrm{~m}$ (12 ft) in elevation. Southeast Pond will remain a seasonally flooded wetland as a result of mitigation. 
A HYDROLOGIC ANALYSIS OF GOVERNMENT ISLAND, OREGON

\author{
by
}

Scott Gregory Bittinger

A thesis submitted in partial fulfillment of the requirements for the degree of

\author{
MASTER OF SCIENCE \\ in \\ GEOLOGY
}

\author{
Portland State University \\ 1995
}




\section{ACKNOWLEDGEMENTS}

I would like to thank PSU faculty members Ansel Johnson, Michael Cummings, and Kenneth Cruikshank for their advice and extensive amount of time invested in this project. Time and assistance by Stewart Ashbaugh, Greg Briggs, Janine Boer, Taryn Eddy, Rand Fisher, Doann Hamilton, Chris Humphrey, Jim Martin, Brian Petersen, Michael Pollock, Sherry Spencer, Susan Stucker, Christy Vockler, Ken Walsh, and Jennifer Whitebread are greatly appreciated

I would like to thank the Port of Portland for selecting the Center for Science Education at PSU to study and monitor the Government Island wetlands mitigation site and for the funding provided to PSU. 
PAGE

ACKNOWLEDGEMENTS ...................... i

TABLE OF CONTENTS ........................ i

LIST OF TABLES........................... iv

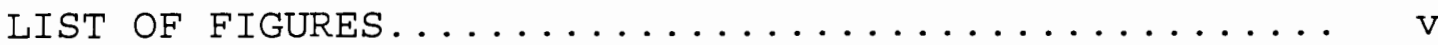

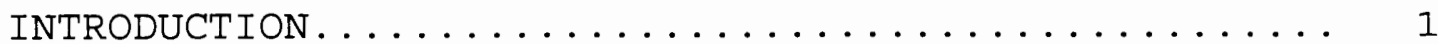

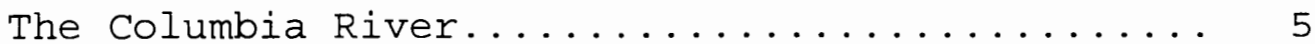

Late Pleistocene/Holocene geology............. 8

Historical changes on Government Island......... 11

PRESENT WETLAND CONDITIONS ON GOVERNMENT ISLAND...... 13

HYDROGEOLOGY OF THE GOVERNMENT ISLAND WETLAND . . . . . . 22

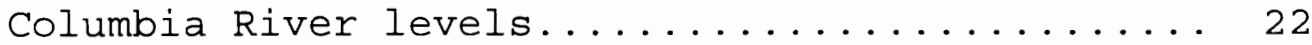

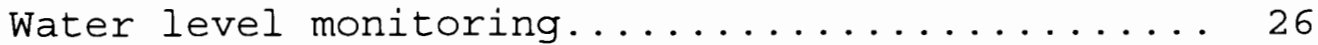

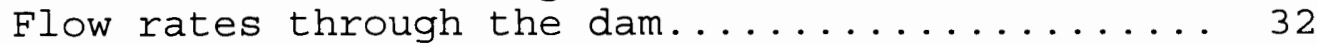

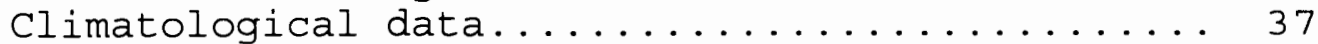

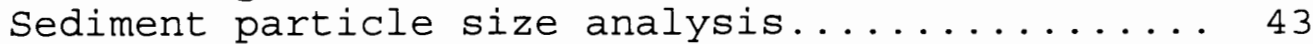

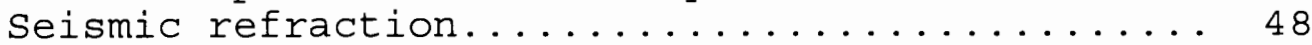

Summary of factors affecting the hydrogeology of

the Government Island mitigation site......... 51

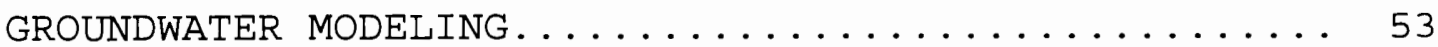

GROUNDWATER MODEL DESIGN................ 53

Stratigraphic representation in the

groundwater model................. 53

Evapotranspiration in the groundwater model 62

Calibration of the groundwater model..... 66

RESULTS OF GROUNDWATER MODELING............ 71

Climate as a variable in groundwater

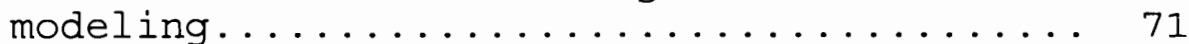

Hydraulic conductivity of the confining

unit as a variable in groundwater modeling. 80

Aquifer transmissivity as a variable in

groundwater modeling............... 86

Predictions of site conditions based on groundwater modeling.............. 86

Summary of the groundwater model design parameters and the results of groundwater

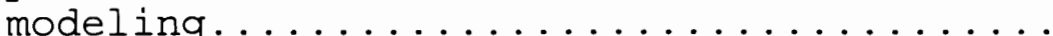

DISCUSSION OF HYDROLOGY .................... 94 
TABLE OF CONTENTS (Continued)

DISCUSSION OF EXPECTED WETLAND CONDITIONS FOLLOWING

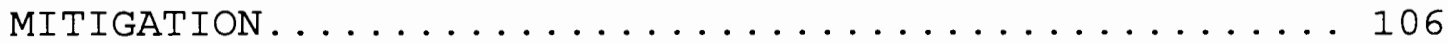

RECOMMENDATIONS FOR FUTURE WORK AND IMPROVEMENTS TO

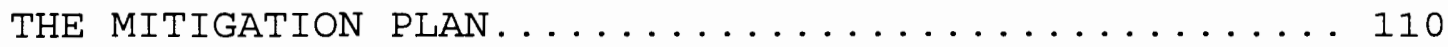

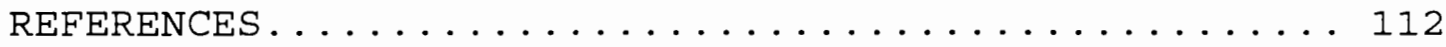

APPENDICES

1. HYDROGRAPHS OF THE COLUMBIA RIVER FROM 1973

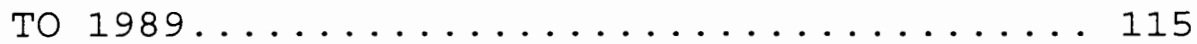

2. PARTICLE SIZE DISTRIBUTIONS......... 133

3. SEISMIC REFRACTION DATA............ 149

4. STRATIGRAPHIC COLUMNS............. 160 
I Approximate water depths in Southeast Pond between October $23 \mathrm{rd}$ and October

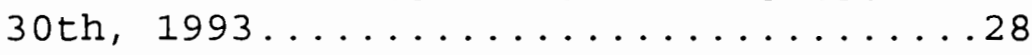

II Government Island water levels......29

III The volume of water in Jewit Lake and Southeast Pond at lake levels between

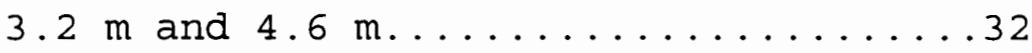

IV Flow rates through the dam as water flowed into Jewit Lake in January and February of 1995...................

$\mathrm{V}$ The grain size percentages for 15 samples collected on Government Island.................. 47

VI Seismic refraction on Government Island; May 7th and 8th, 1994......51

VII Approximate elevations of the aquifer top at the locations shown in Figure

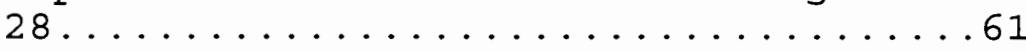

VIII Actual and modeled water levels on Government Island for February, March,

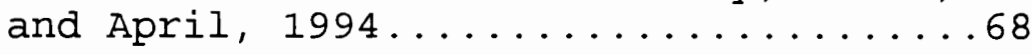

IX Simulation identifying months where water is absent in Jewit Lake and Southeast Pond for years when flooding occurs through the spillway channel...................76

$\mathrm{X}$ Summary of the variables used in MODFLOW to simulate the hydrogeology of Government Island.............93 


\section{FIGURE}

\section{LIST OF FIGURES}

1. Location of the Portland International

PAGE

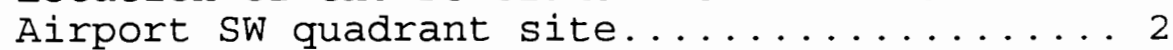

2. Map showing Government Island, and the

Portland, Oregon and Vancouver, Washington

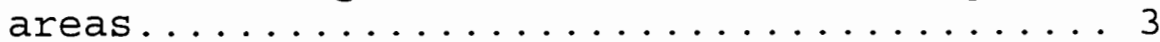

3. Map of Government Island, Oregon..........4

4. The stages of the development of a braid in a laboratory flume river..............

5. Geologic cross section based on drill holes across the I-205 bridge...............10

6. Modern monthly adjusted flow of the Columbia River at Vancouver, Washington and at the

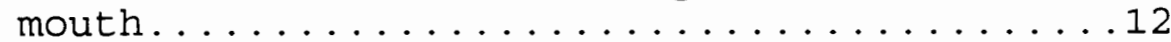

7. A one foot contour map of the mitigation site........................... 14

8. The Government Island mitigation site dam...15

9. Map of the predicted wetland areas resulting

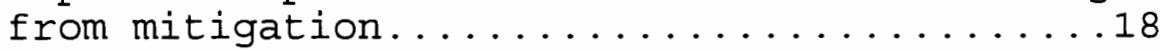

10. River stage at Government Island in 1993...23

11. River stage at Government Island in 1994...24

12. Mean Columbia River elevation at Government

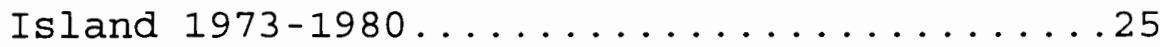

13. Locations of water monitoring points......30

14. Volume of water in Jewit Lake at water levels between $3.2 \mathrm{~m}(10.5 \mathrm{ft})$ and $4.6 \mathrm{~m}$

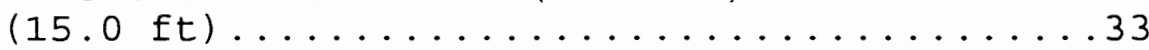

15. Volume of water in Southeast Pond at water levels between $3.5 \mathrm{~m}$ ( $11.5 \mathrm{ft}$ ) and $4.6 \mathrm{~m}$

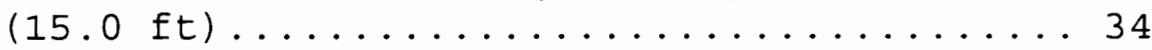

16. River level, Jewit Lake level, and Southeast Pond level from November 1, 1994 to February

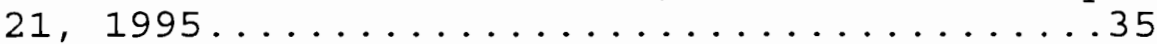




\section{LIST OF FIGURES (continued)}

FIGURE

17. Time required to raise Jewit Lake from $3.6 \mathrm{~m}$ (12 ft) to $4.6 \mathrm{~m}$ (15 ft) based on flow rates through the dam in January and February,

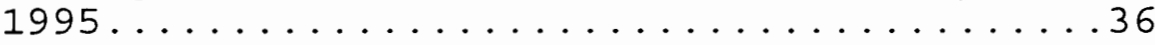

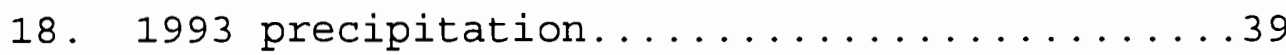

19. 1994 precipitation...................40

20. 1993, 1994, and average monthly evapotranspiration in Vancouver, washington.41

21. Evapotranspiration and lake evaporation for selected days in June, 1994...........44

22. Hydrometer sampling site locations.......46

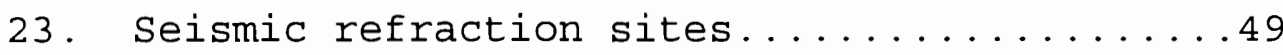

24. MODFLOW node grid. Each node is $152 \mathrm{~m}$ by 152 m $(500 \mathrm{ft}$ by $500 \mathrm{ft}) \ldots \ldots \ldots \ldots \ldots$

25. Schematic diagram of cross section $A-A^{\prime}$ as entered into MODFLOW.................55

26. Location of Jewit Lake and Southeast Pond in MODFLOW at elevations above $3.6 \mathrm{~m}$ (12 ft)...56

27. Locations of Jewit Lake and Southeast Pond in MODFLOW at elevations between 3.3 and 3.6 $\mathrm{m}(11$ and $12 \mathrm{ft}) \ldots \ldots \ldots \ldots \ldots$

28. Locations where the aquifer was located during fieldwork................60

29. Cross section $A-A^{\prime} \ldots \ldots \ldots \ldots . \ldots . \ldots 63$

30. Cross section $B-B^{\prime} \ldots \ldots \ldots \ldots 64$

31. Site locations used for cross section

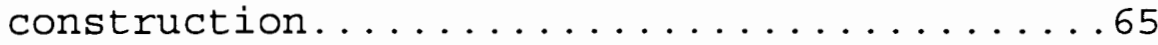

32. Evapotranspiration as a function of head...67

33. Precipitation, evapotranspiration, and groundwater infiltration from June through December with average precipitation and evapotranspiration rates.............72 


\section{LIST OF FIGURES (continued)}

FIGURE

34. Precipitation, evapotranspiration, and

PAGE groundwater infiltration from June through December with above average precipitation and below average evapotranspiration rates..73

35. Precipitation, evapotranspiration, and groundwater infiltration from June through December with below average precipitation and above average evapotranspiration rates..74

36. Water levels in Jewit Lake from June through December with variable rates of precipitation in years when no flooding occurs through the spillway channel......77

37. Water levels in Southeast Pond from June through December with variable rates of precipitation in years when no water flows overland from Jewit Lake to flood Southeast Pond....................78

38. Monthly evapotranspiration entered into

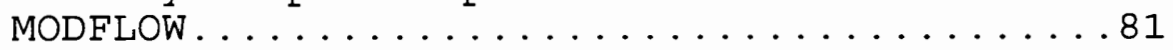

39. Variations in Southeast Pond water levels from June 1, 1994 to September 1, 1994 using hydraulic conductivity values given for silts.....................84

40. Variations in Jewit Lake water levels from June through November using hydraulic conductivity values given for silts.......85

41. Variations in Jewit Lake water levels from June through November using transmissivity values given for sands.............87

42. Variations in Southeast Pond water levels from June through November using transmissivity values given for sands.....88

43. Jewit Lake levels from May 31st to December 31st with average precipitation..........89

44. Southeast Pond levels from May 31 st to December 31 st with average precipitation...90 


\section{LIST OF FIGURES (continued)}

FIGURE

45. Zone of higher hydraulic conductivity at

seismic refraction station $\mathrm{G}-9 \ldots \ldots . \ldots 98$

46. Locations of stratigraphic columns that were not used for cross section

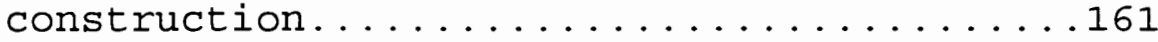




\section{INTRODUCTION}

Wetlands are vital ecosystems that provide habitat for wildlife, recharge of groundwater systems, and temporary storage of water during periods of high discharge. Concern over loss of wetlands prompted the U.S. Congress to include provision $404 \mathrm{~b}$ in the Clean water Act of 1980 (Experimental Laboratory, 1987). This provision requires no net loss of wetlands and allows development of new wetlands as a mitigation where existing wetlands have been destroyed or modified. Expansion of the southwest quadrant of Portland International Airport (Figure 1) by the Port of Portland prompted development of a mitigation site on Government Island in the Columbia River.

Government Island is a $9.5 \mathrm{~km}^{2}(2000$ acre) (SRI, 1991a) alluvial river bar located between river mile 111.5 and 117.5 of the Columbia River, approximately $8 \mathrm{~km}$ (5 mi) east of Portland, Oregon (Figure 2). The island is owned and managed by the Port of Portland. One square kilometer (237 acres) selected as the mitigation site (Figure 3) is to be modified from seasonally flooded wetlands to a combination of semi-permanently flooded and seasonally flooded wetlands. Site modifications to produce the desired results included construction of a dam at the end of a channel that connects Jewit Lake, the largest area subject to seasonal flooding, and the Columbia River. In 
order to attain the desired mitigation, the hydrology of Government Island plays a critical role. In June, 1993, a program of field observations was implemented to obtain

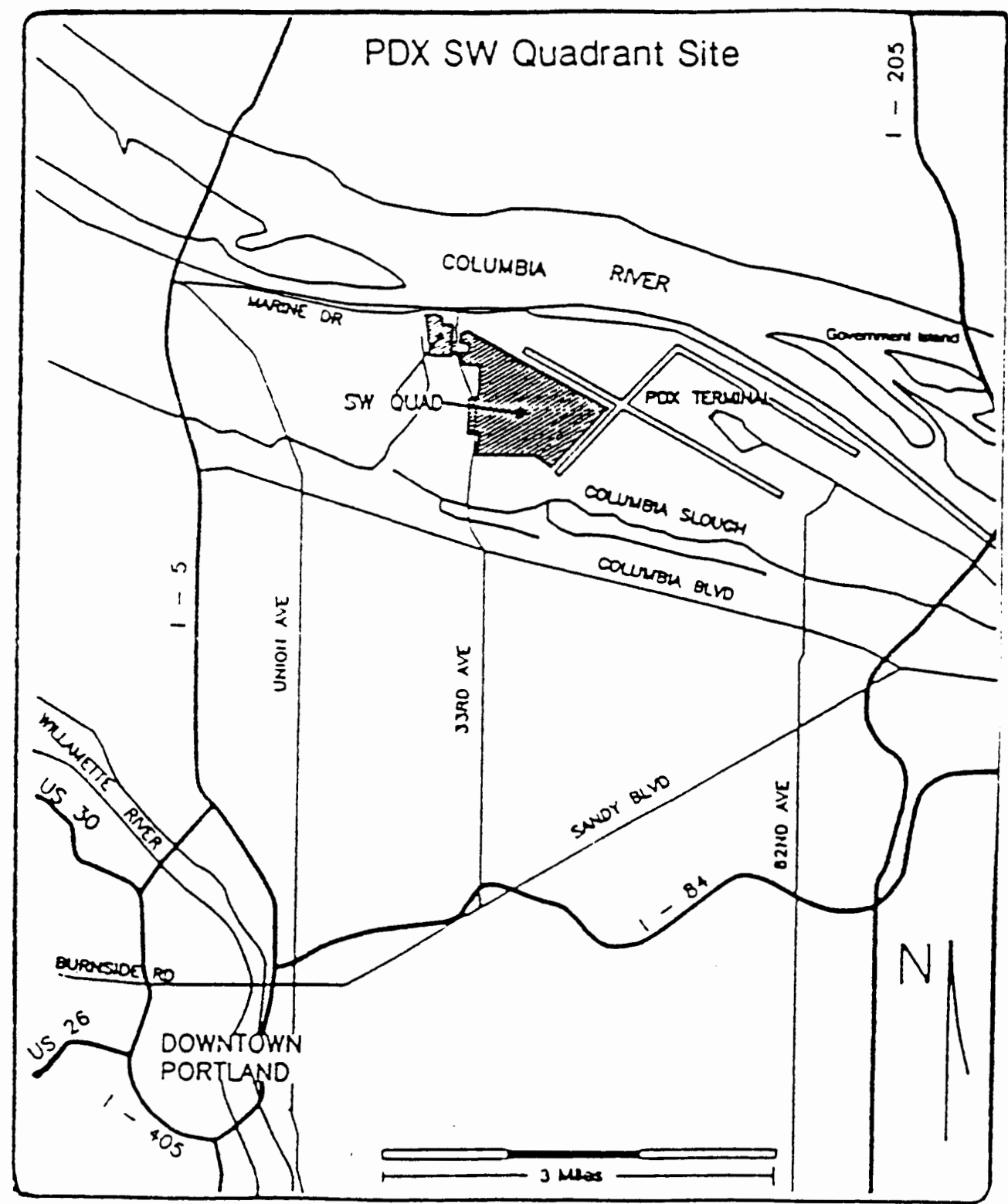

Figure 1. Location of the Portland International Airport SW quadrant site (SRI, 1991a). 


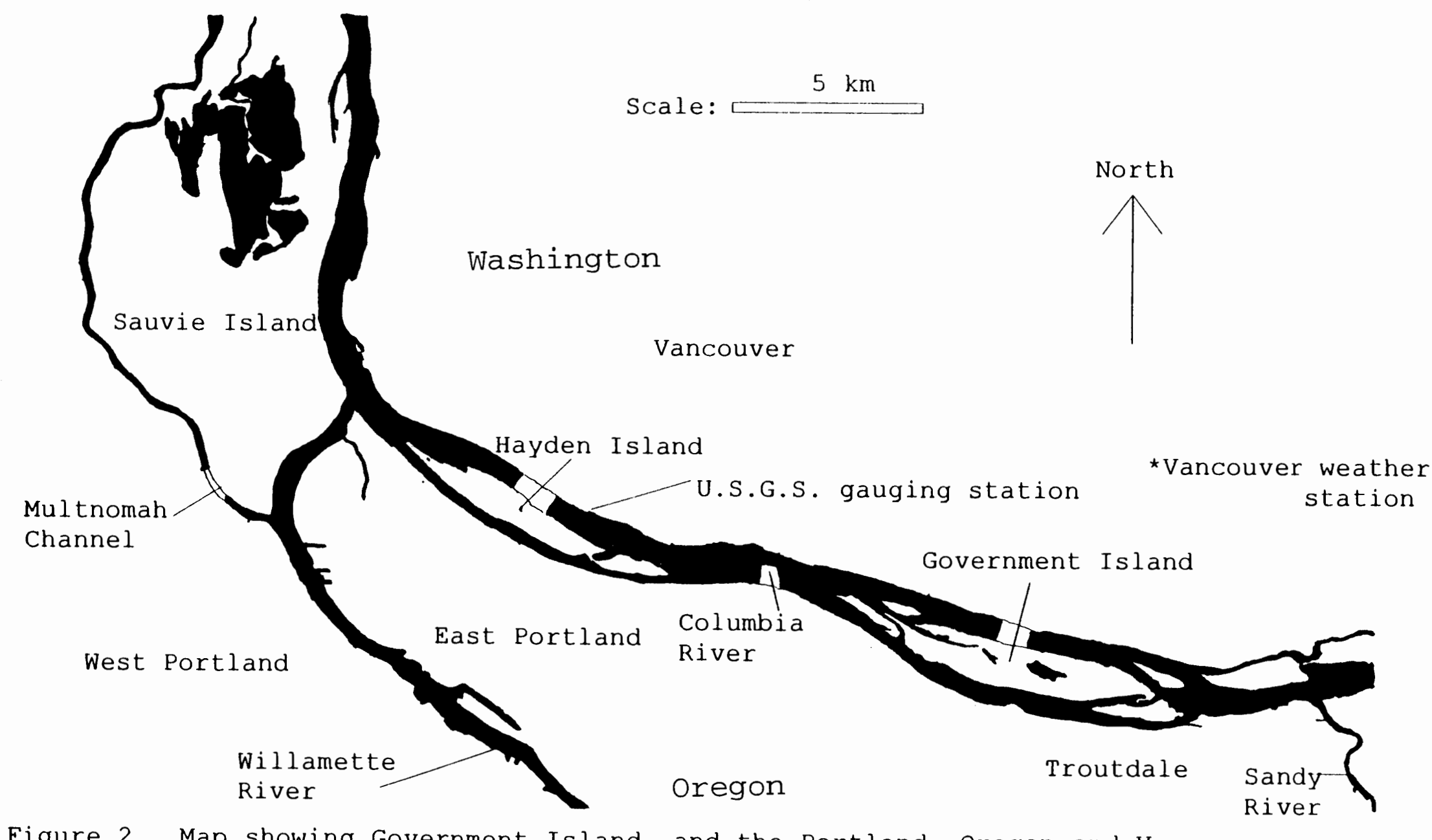
Figure 2. Map showing Government Island, and the Portland, Oregon and Vancouver,
Washington areas. 


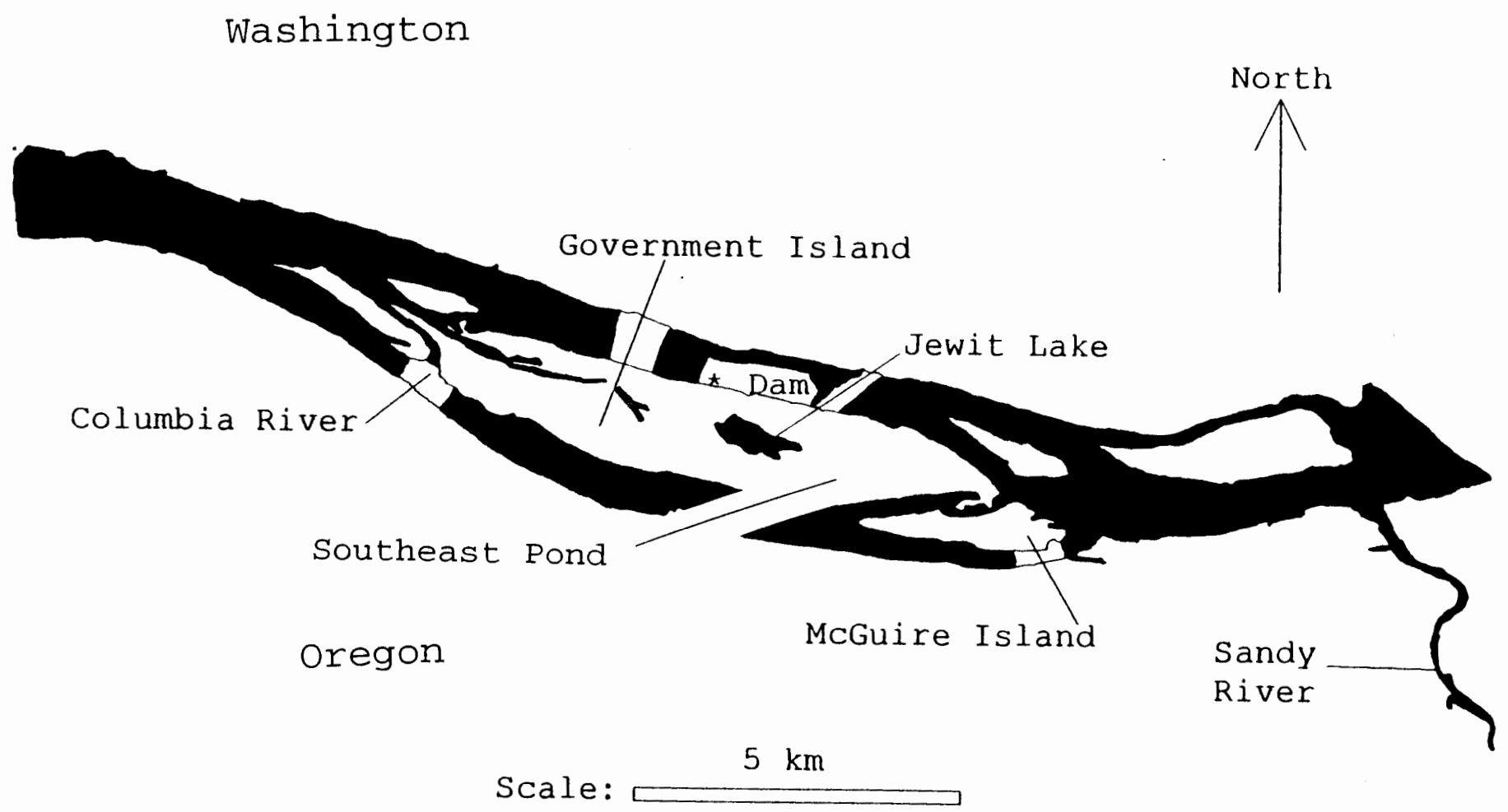

Figure 3. Map of Government Island, Oregon. 
data for development of a groundwater model for the site. Data collection continued during the next 20 months until the end of February, 1995. These data were gathered from Jewit Lake, Southeast Pond, and monitoring points within the study area. The groundwater model relates the water levels of Jewit Lake and Southeast Pond to levels of the Columbia River, precipitation, and evapotranspiration.

\section{The Columbia River}

The drainage basin of the Columbia River covers an area of $660,480 \mathrm{~km}^{2}\left(245,765 \mathrm{mi}^{2}\right)$. The Columbia River has a mean annual flow rate of approximately $6,800 \mathrm{~m}^{3} / \mathrm{s}$ $\left(240,139 \mathrm{ft}^{3} / \mathrm{s}\right)$ (Simenstad and others, 1990). Construction of hydroelectric dams beginning in 1937 altered the natural rates and timing of river stage events (Sherwood and others, 1990). Maximum flow rates of the Columbia River are now significantly smaller than peak flow rates prior to dam construction. Land tracts adjacent to and within the Columbia River were once seasonally inundated by the spring flooding of the Columbia River. Since flow rates are now restricted, much of this land area is no longer inundated on a yearly basis.

The Lower Columbia River, where Government Island is located, is a braided river characterized by channel 
division around alluvial islands. The growth of an island begins by the deposition of a channel bar due to sorting and deposition of the coarser fractions of the bedload which locally cannot be transported. The channel bar grows downstream and in height by continued deposition, forcing water into the flanking channels, which, to carry the flow, deepen and cut laterally into the original banks (Figure 4). Such deepening locally lowers the water surface and the central bar emerges as an island stabilized by vegetation (Leopold and Wolman, 1957).

Figure 4 shows the stages of the development of a braid in a laboratory flume experiment performed by Leopold and Wolman (1957). Comparison of a flume river to a natural river is based on the principle that processes occurring on a small scale are similar to those that occur on a large scale. This model does not consider changes in flow rates that rivers experience. The landforms found in the Lower Columbia River (Figure 2) resemble those formed in flume experiments (Figure 4). Continual shifting of channels builds a heterogenous bar consisting of patches of materials of different size and degrees of sorting (Leopold and Wolman, 1957).

Channel bar sediments in the Lower Columbia River are likely to have a particle size distribution that is coarser than fine sand since coarser fractions of the 

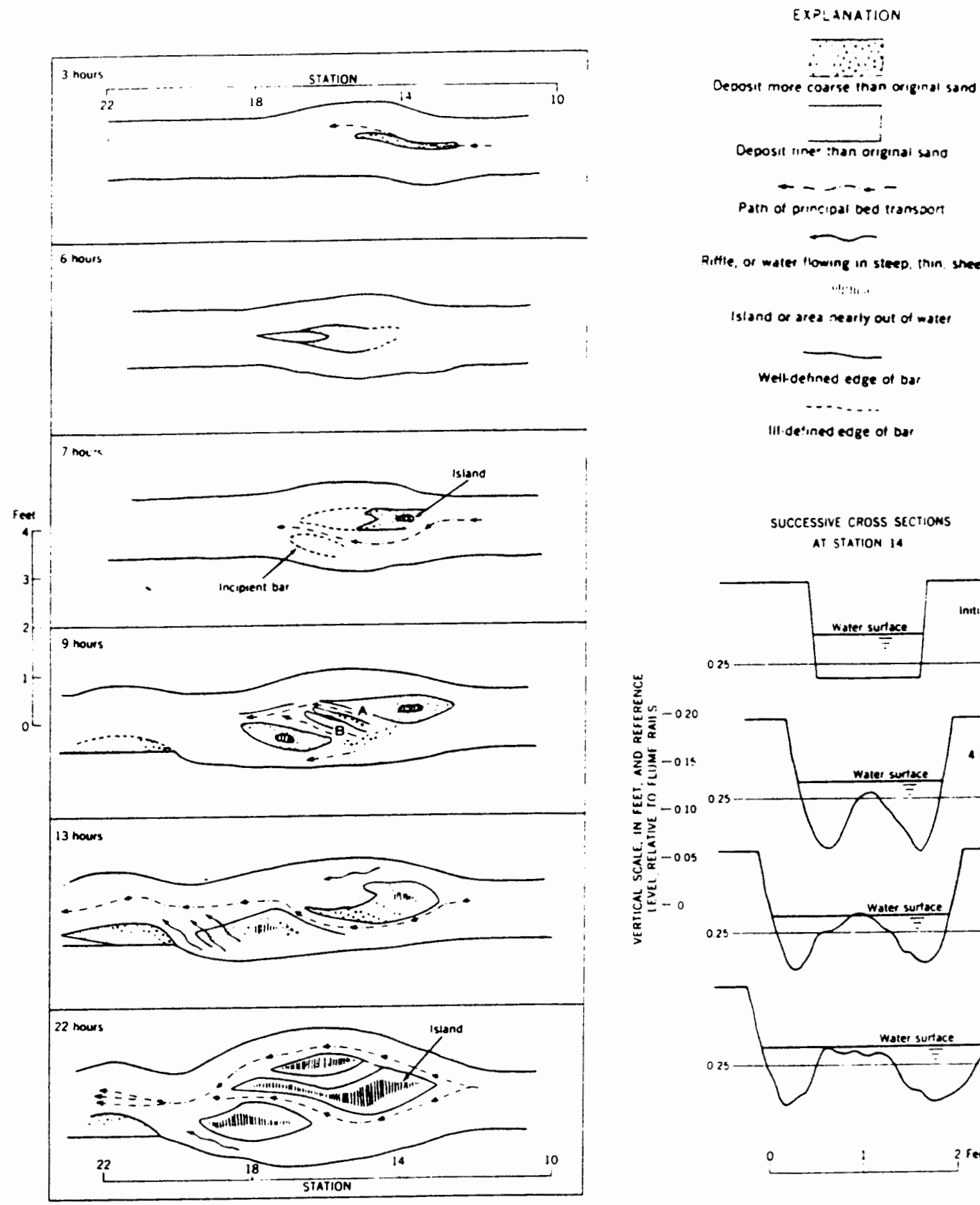

sland or area nearly out of water

Wettofined edge of bar

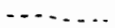

III. detined eoge of bes

SUCCESSIVE CROSS SECTIONS AT STATION 14
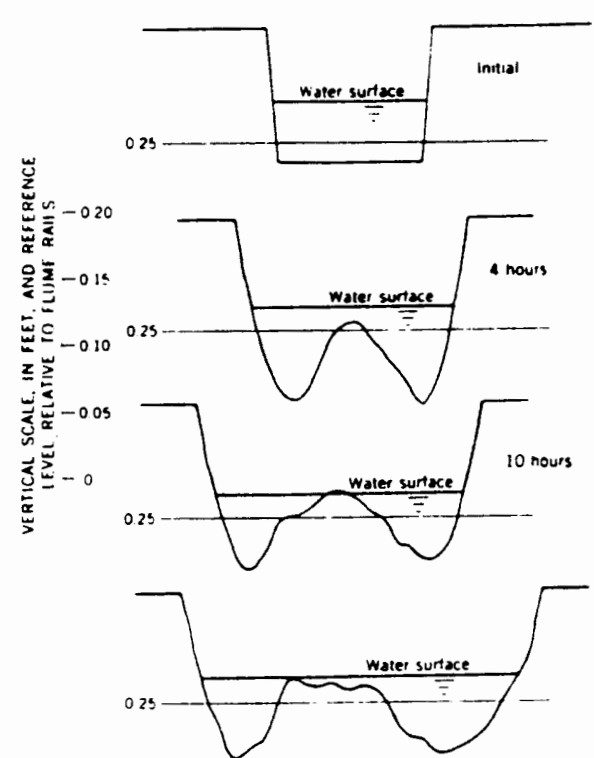
2 Feet

Figure 4. The stages of development of a braid in a laboratory flume experiment (Leopold and Wolman, 1957). 
bedload are more difficult to transport. Holocene sediments in the Lower Columbia River Basin are dominantly fine sands (Gates, 1994).

\section{Late Pleistocene/Holocene Geology}

Between 15,300 years and 12,700 years B.P. (Wait,, 1985) catastrophic flooding occurred in the Columbia River Valley. These floods occurred periodically as glacial Lake Missoula slowly filled and catastrophically emptied its waters. Each filling of Lake Missoula contained over $2100 \mathrm{~km}^{3}\left(500 \mathrm{mi}^{3}\right)$ of water. Within a few weeks, up to $1590 \mathrm{~km}^{3}$ (380 $\left.\mathrm{mi}^{3}\right)$ of water would break away an ice dam and flow towards the Columbia River valley at velocities of 49-8I kph (30-50 mph) (Allen and others, 1986). The flood waters scoured the Columbia River valley between 40 and 100 times (Waitt, 1985). The last great flood inundated the Portland basin to an elevation of $130 \mathrm{~m}(400$ ft) 12,700 years ago (Allen and others, 1986).

In latest Pleistocene time, sea level began to rise as continental ice sheets and polar ice caps began melting. During Holocene time the lower Columbia basin began infilling with sediment. Sea level rise has the same general sedimentologic effect as damming a river (Gates, 1994). The river adjusts to a higher base level by aggrading sediments in an upstream direction. It was 
during this aggradation that Government Island evolved as an alluvial island in the columbia River channel.

In the Portland area, the Troutdale Formation and the Sandy River Mudstone form the basal contact of the post Missoula Flood deposits of the lower Columbia River (Gates, 1994). A cross section across the west end of Government Island based on drill holes for the I-205 Glen Jackson Bridge (Figure 5) constructed by Gates (1994) shows the alluvial Troutdale Formation contact ranges between $-24 \mathrm{~m}(-80 \mathrm{ft}) \mathrm{m.s.l}$. beneath the northern channel of the Columbia River to $-55 \mathrm{~m}$ (-180 ft) m.s.l. beneath the Oregon shoreline of the Columbia River (Figure 5) (Gates, 1994). Beneath the Oregon shoreline of the Columbia River, the Troutdale Formation pinches out. The pinchout of the Troutdale Formation occurs at a $24 \mathrm{~m}$ (80 ft) scour channel cut into the upper sandy River Mudstone Formation (Gates, 1994). It is unknown whether this channel eroded during the Missoula floods or is a feature formed by the early Holocene Columbia River.

Government Island is part of the Horseshoe geomorphic surface of Multnomah County, Oregon (Parsons and Green, 1982). The Horseshoe surface is one of low relief and includes the stream channel and associated features (point bar deposits, channel fillings, and abandoned meanders). The surface is generally underlain by coarse-grained or 


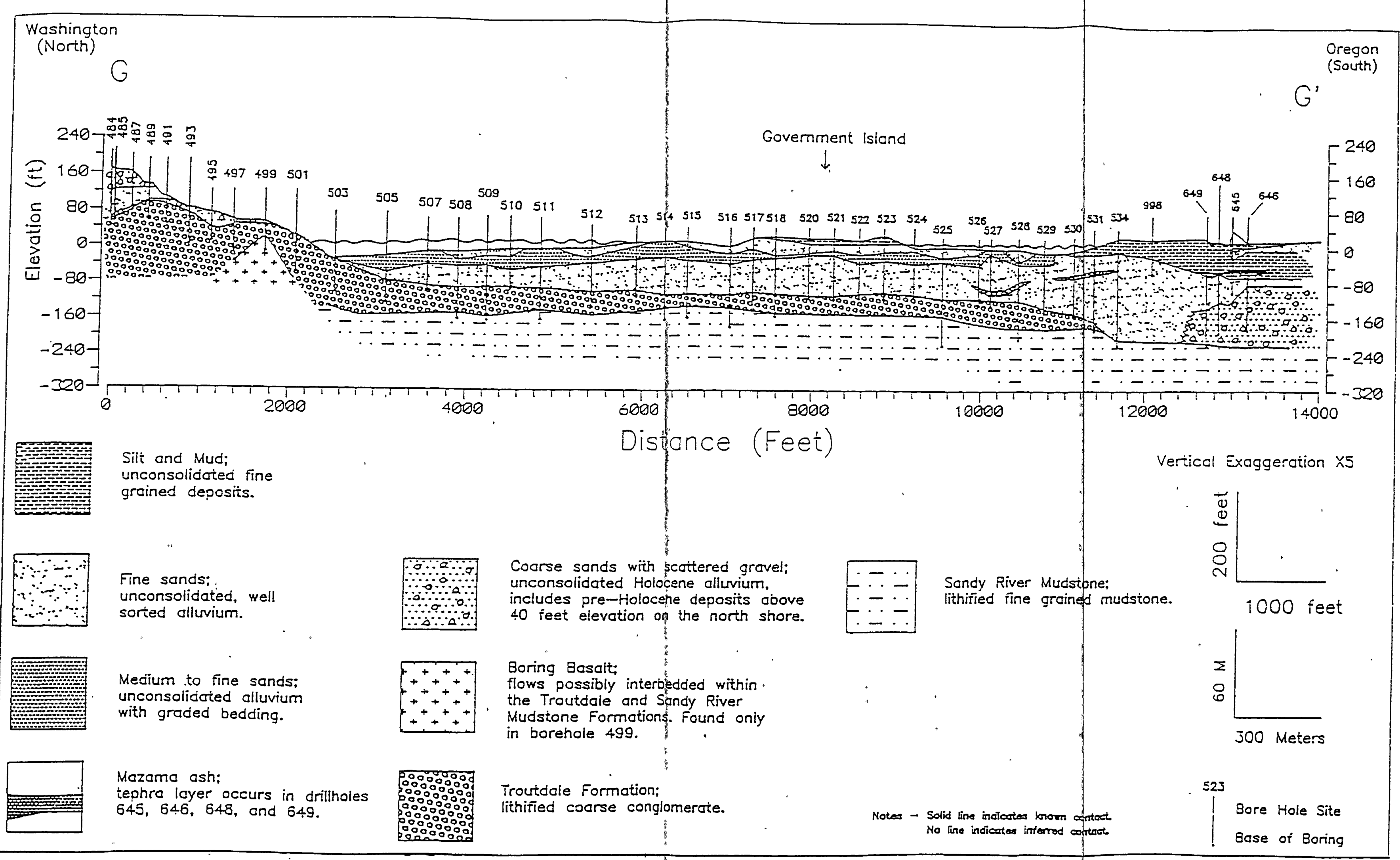

Figure 5. Geologic cross section based on drill holes across the I-205 bridge (Gates, 1994). 
moderately coarse-grained alluvium. Elevations are generally less than $6 \mathrm{~m}(20 \mathrm{ft})$.

Soils of the Horseshoe surface are too young to show well developed weathering horizons on Government Island. Four soils; the Rafton, Sauvie, Faloma silt loams and the Pilchuck sand, are present (Soil Survey Staff, 1983). The Rafton, Sauvie, and Faloma silt loams are distinguished by vegetation, elevation, thickness of organic horizons, depth to mottles, the presence or absence of gleying, and the amount of time annually that water is present at the ground surface (Soil Survey Staff, 1992).

\section{Historical changes on Government Island}

Following construction of hydroelectric dams on the Columbia River beginning in 1937, the hydrology of Government Island changed. Hydroelectric dams store water at all times of the year, modifying the length and level of peak river flows. The decreased level of peak river flows prevents Government Island from being inundated with water on an annual basis. Estimates of unregulated average discharges of the Columbia River from 1969 through 1982 based on river level data are given in Figure 6 (Sherwood and others, 1990). Unregulated runoffs are approximated by adjusting for monthly reservoir storage. Figure 6 shows that highest average monthly river flows 
would occur in April, May, and June if flow rates were unregulated.

Inspection of aerial photographs show that trees became established on Government Island following construction of hydroelectric dams on the Columbia River. Annual flooding of Government Island prior to regulation of river flows likely prevented trees from becoming established.

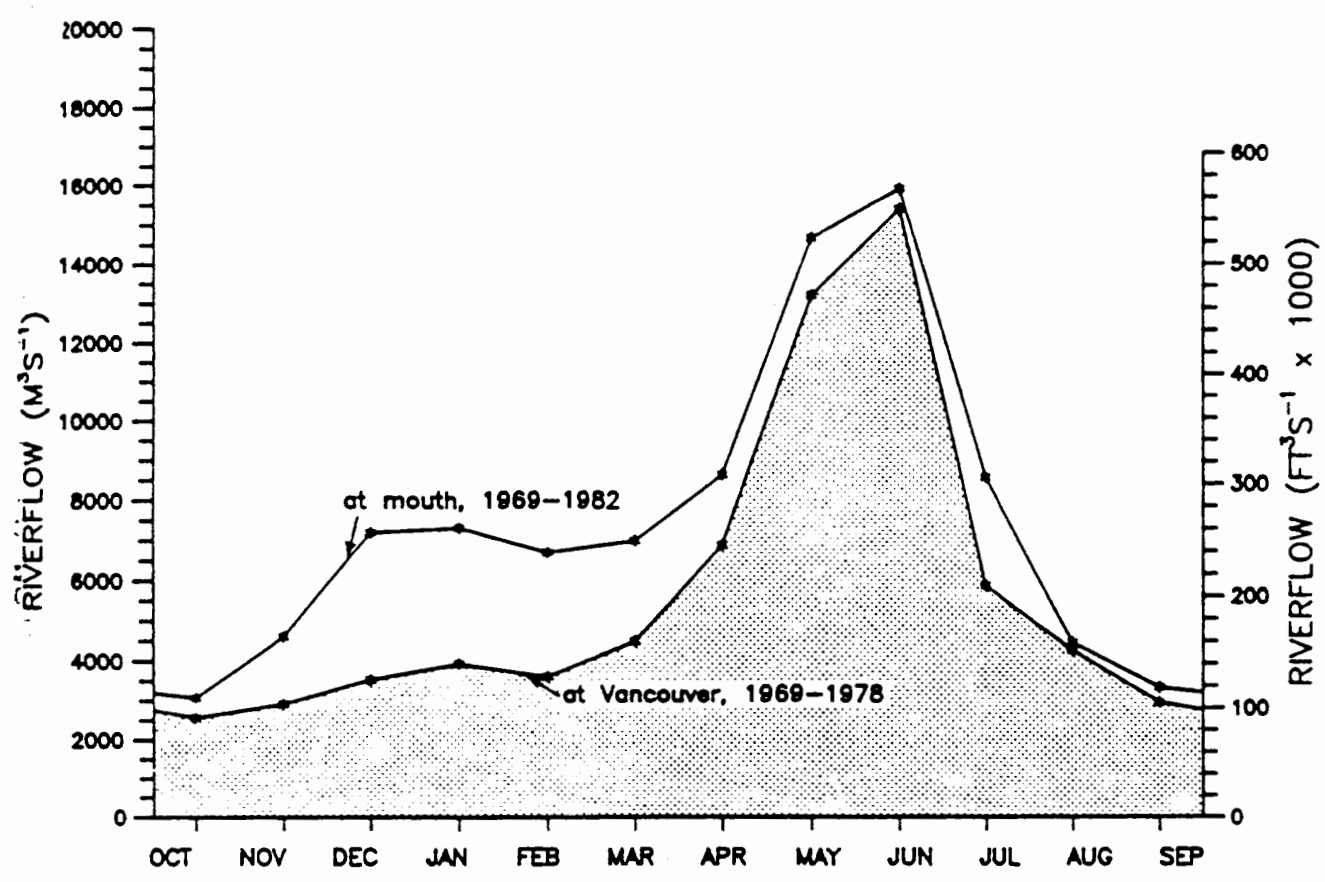

Figure 6. Modern monthly mean adjusted flow of the Columbia River at Vancouver, Washington and at the mouth. Monthly flows have been averaged for the period 1969-1982 and adjusted for reservoir storage to approximate natural runoff conditions (Sherwood and others, 1990). 


\section{PRESENT WETLAND CONDITIONS ON GOVERNMENT ISLAND}

Figure 7, prepared by Oakley Engineering Inc. (1992), shows the mitigation areas selected for this study. A channel was excavated between 1937 and 1945 between the north channel of the Columbia River and the northwest edge of Jewit Lake (Figure 7). The original purpose of this channel was to drain Jewit Lake in the summer months to allow grazing and agriculture. The channel is now being used to flood Jewit Lake during peak flow events of the Columbia River. A dam that allows water to flow into Jewit Lake was constructed in October of 1993 by the Port of Portland at the mouth of the channel to retain water in Jewit Lake and prevent fish from entering Jewit Lake. A schematic diagram of the inside face of the dam is shown in Figure 8. The dam allows water to flow through springloaded gates when the Columbia River reaches an elevation at Government Island between 3.6 and $4.7 \mathrm{~m} \mathrm{(12} \mathrm{and} \mathrm{15.3}$ ft) m.s.l. The spring loaded gates close themselves when the Columbia River drops below the water level in Jewit

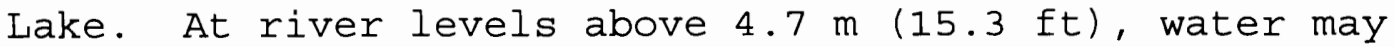
flood Jewit lake by flowing through an open spillway grating. If Jewit Lake reaches a level above $4.7 \mathrm{~m}(15.3$ ft), water will flow back out into the Columbia River through the open spillway grating. Thus the dam can maintain a maximum water level of $4.7 \mathrm{~m}(15.3 \mathrm{ft})$ in Jewit Lake. 


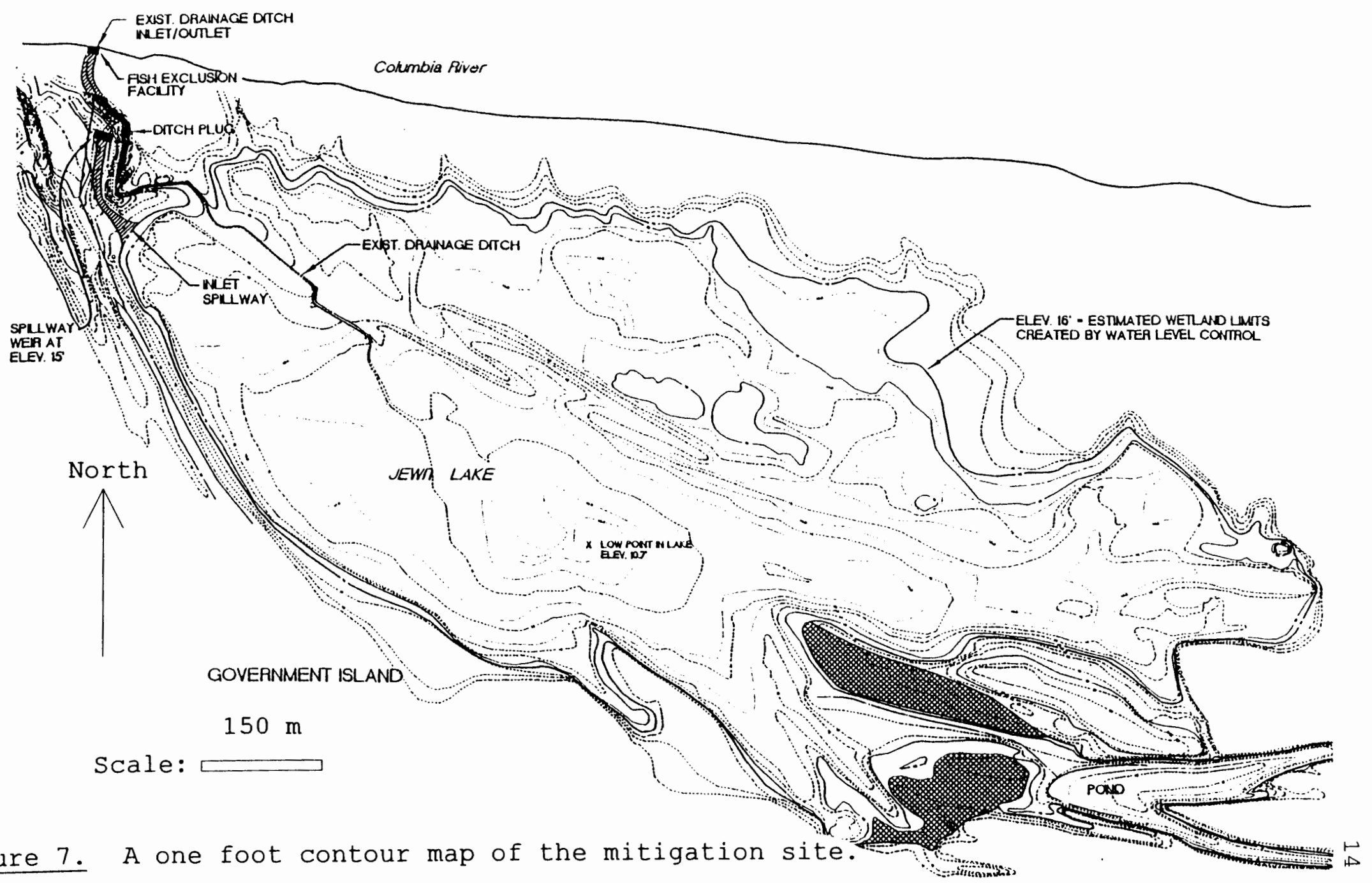


$7.2 \mathrm{~mm} . \mathrm{s} .1$.

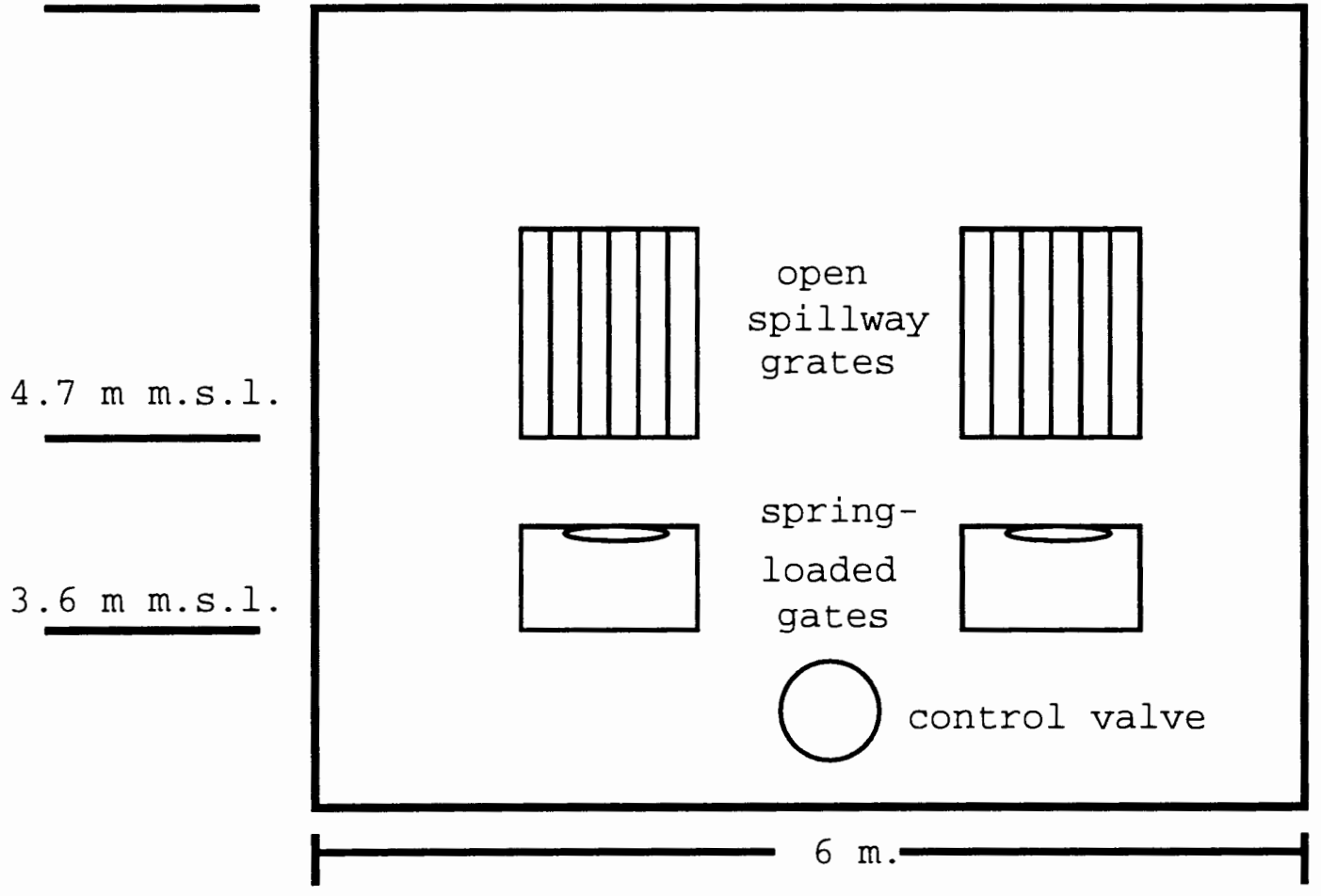

Figure 8. Government Island mitigation site dam. This view is facing north (downstream) from the spillway channel. 
Jewit Lake and Southeast Pond (labeled 'Pond' in Figure 7), are ephemeral lakes which contain water 3 to 10 months of the year depending on levels of the Columbia River, precipitation, and evapotranspiration. The spillway weir and inlet spillway shown in Figure 7 have not been constructed. The ditch plug shown in Figure 7 was placed in the channel in 1992. The ditch plug was used to hold water in Jewit Lake before the dam at the mouth of the channel was constructed. The ditch plug was removed in November of 1993 following completion of the dam.

Modification of the Government Island wetland from seasonally flooded wetlands to a combination of semipermanently flooded and seasonally flooded wetlands should change the times of the year that surface water is present in the Government Island wetland. Seasonally flooded wetlands in the Government Island area should contain water early in the growing season (approximately May through July) and have dry conditions late in the growing season (approximately August through October). Semipermanently flooded wetlands in the Government Island area should contain water throughout the growing season (approximately May through October) in most years (Cowardin and others, 1979, Soil Survey Staff, 1983). According to the U.S. Fish and Wildlife Service 
Classification of Wetlands in the United States, the study area on Government Island satisfies criteria for the palustrine system at the broadest level of the classification hierarchy (Cowardin and others, 1979). Palustrine wetlands may be situated shoreward of lakes, river channels, or estuaries; on river floodplains; in isolated catchments; or on slopes. They may also occur as islands in lakes or rivers.

Palustrine emergent and palustrine forested are the two classes of wetland found in the study area. Approximately $0.77 \mathrm{~km}^{2}$ (161 acres) of palustrine emergent wetland and $0.36 \mathrm{~km}^{2}(76$ acres $)$ of palustrine forested wetland are present within the pre-mitigated study area (Galen and others, 1992). The mitigation plan of Galen and others (1992) indicates that $1.07 \mathrm{~km}^{2}$ (225 acres) of persistent emergent wetland and $0.20 \mathrm{~km}^{2}$ (42 acres) of forested wetland are expected to be present following 5 years of mitigation. Figure 9 shows where the palustrine emergent and palustrine forested wetland are expected to be located following mitigation. The persistent emergent wetland is expected to contain a submergent plant community $\left(0.34 \mathrm{~km}^{2}, 73\right.$ acres $)$ and an emergent plant community $\left(0.72 \mathrm{~km}^{2}, 152\right.$ acres).

The emergent wetland subclass of the palustrine emergent class is characterized by erect, rooted, 


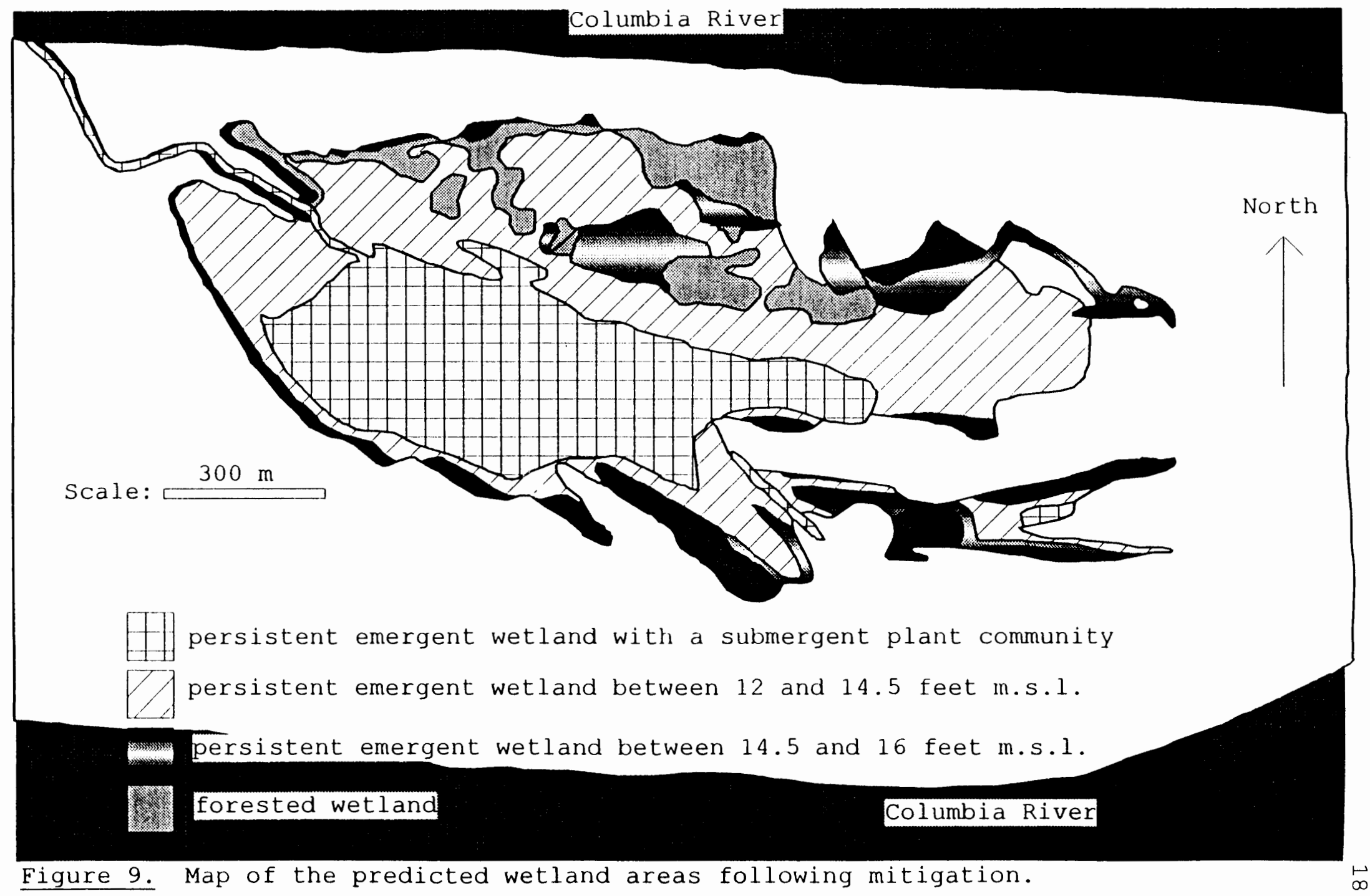


herbaceous hydrophytes, excluding mosses and lichens. The wetlands on Government Island are dominated by Calamagrostis A. (reed canary grass), a perennial herbaceous species that is not native to Oregon. Reed canary grass is not a hydrophyte because it grows in wetland and non-wetland conditions (S. Spencer, personal communication, 1995). Even though reed canary grass is not a hydrophyte, $0.77 \mathrm{~km}^{2}$ (161 acres) have been delineated as persistent emergent wetland (SRI, 1991b, Galen and others, 1992). Plant associations and soil characteristics were used to delineate the Government Island wetland.

A submergent plant community is expected to be present between elevations of 3.2 and $3.6 \mathrm{~m}(10.5$ and 12 ft) as a result of mitigation (Galen and others, 1992). Submergent plants lie entirely beneath the water surface except for flowering parts in most species (Cowardin and others, 1979). Periodic drying of the lakes below $3.6 \mathrm{~m}$ (12 ft) was expected to effect the submergent plant community. The submergent plant community is expected to tolerate periodic drying of the lakes. Lake levels are expected to remain above $3.6 \mathrm{~m}(12 \mathrm{ft})$ in most years after mitigation (Oakley, 1992, Galen and others, 1992).

Persistent emergent plant communities are expected to exist between 3.6 and $4.9 \mathrm{~m} \mathrm{(12} \mathrm{and} 16 \mathrm{ft}$ ) in elevation. 
The plant communities between 3.6 and $4.4 \mathrm{~m}$ (12 and 14.5 ft) are expected to differ from the plant communities between 4.4 and $4.9 \mathrm{~m} \mathrm{(14.5}$ and $16 \mathrm{ft}$ ) in elevation. Eleocharis R. Br. (spikerush), Scirpus L. (bulrush), Bidens L. (beggars tick), Sagittaria L. (wapato), and Typha L. (cattail) (Hitchcock and Cronquist, 1973) are expected to become the dominant plant species between 3.6 and $4.4 \mathrm{~m}$ (12 and $14.5 \mathrm{ft}$ ) in elevation, with surface water present 6-12 months of the year. Herbaceous hydrophyte grasses are expected to be present between 4.4 and $4.9 \mathrm{~m} \mathrm{(14.5}$ and $16 \mathrm{ft})$ in elevation. Surface water is expected to be present 6 months of the year to a maximum depth of $0.5 \mathrm{~m}$ ( $1.5 \mathrm{ft}$ ) following mitigation (Galen and others, 1992).

Sections of Jewit Lake and Southeast Pond are nonpersistent emergent wetlands because at times of the year there is no emergent vegetation. This type of wetland is found below about $3.8 \mathrm{~m}(12.5 \mathrm{ft})$. The areas within the lakes that have surface water present for the greatest amount of time during the year are nonpersistent emergent wetlands. Centunculus minimus (S. Spencer, personal communication, 1995), an emergent vascular plant, grows in these areas following lake drying during the growing season. C. minimus is an annual mudflat species that must germinate each year. C. minimus will not 
germinate in standing water and does not occur in the presence of surface water. The presence of $C$. minimus below $3.8 \mathrm{~m}$ ( $12.5 \mathrm{ft}$ ) indicates that perennial surface water must not have been present in the study area prior to site mitigation.

Areas within the Government Island wetland that support trees are classified as forested wetlands. Forested wetland is characterized by woody vegetation that is $6 \mathrm{~m}$ (19 ft) or taller. Salix lasiandra (Pacific Willow) and Populus trichocarpa (Black Cottonwood) (Arno, 1977) are the dominant species in the Government Island forested wetland. These species are characteristic of the broad-leaved deciduous subclass of forested wetland.

Water regimes of wetlands are defined in terms of the growing season since periods of flooding in the dormant season may have little influence on the development of plant communities. The growing season in the Government Island area is from late spring through early fall (soil Survey staff, 1983). The entire Government Island wetland area has a seasonally flooded water regime prior to mitigation. Seasonally flooded wetlands have surface water present for extended periods early in the growing season, but water is absent by the end of the growing season in most years. 


\section{HYDROGEOLOGY OF THE GOVERNMENT ISLAND MITIGATION SITE}

\section{Columbia River Levels}

The elevations (m.s.l.) of the Columbia River were obtained from the U.S. Geological Survey gaging station in Vancouver, Washington at river mile 106.5 (Figure 2). An average river gradient of $0.07 \mathrm{~m} / \mathrm{km}(0.38 \mathrm{ft} / \mathrm{mi})$ (Don Oakley, personal communication, 1993) was added to river stage measurements to adjust for the level of the river at Government Island (river mile 115.5).

Hydrographs of the daily maximum river stage of the Columbia River at Government Island were constructed for 1993 and 1994 (Figures 10 and 11). The elevations of the Columbia River allow one to predict the flooding of Jewit Lake through the dam. A minimum river stage of $3.6 \mathrm{~m}$ (12.0 ft) m.s.1. is necessary for water to reach Jewit Lake through the mitigation site dam (Figure 8). Figure 12 shows the 7 year daily average of the Columbia River elevation at Government Island between 1973 and 1980 . From Figure 12, the time of year when flooding of Jewit Lake is likely to occur can be determined by locating the time of the year when river levels are highest. Flooding of Jewit Lake is most likely to occur in December, January, May, and June. Hydrographs of the Columbia River from 1973 to 1989 are presented in Appendix 1. 


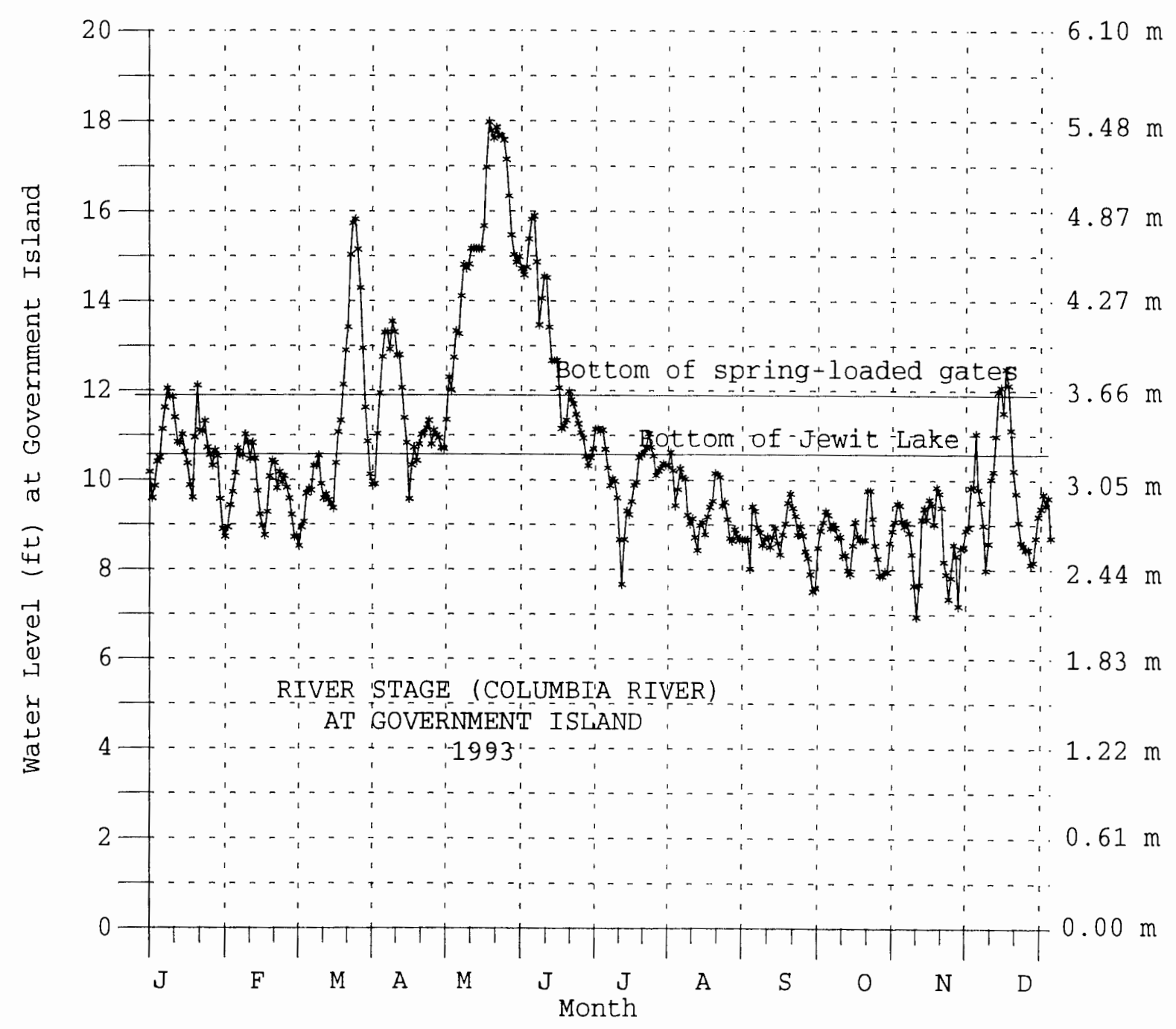

Figure 10. River stage at Government Island in 1993. 


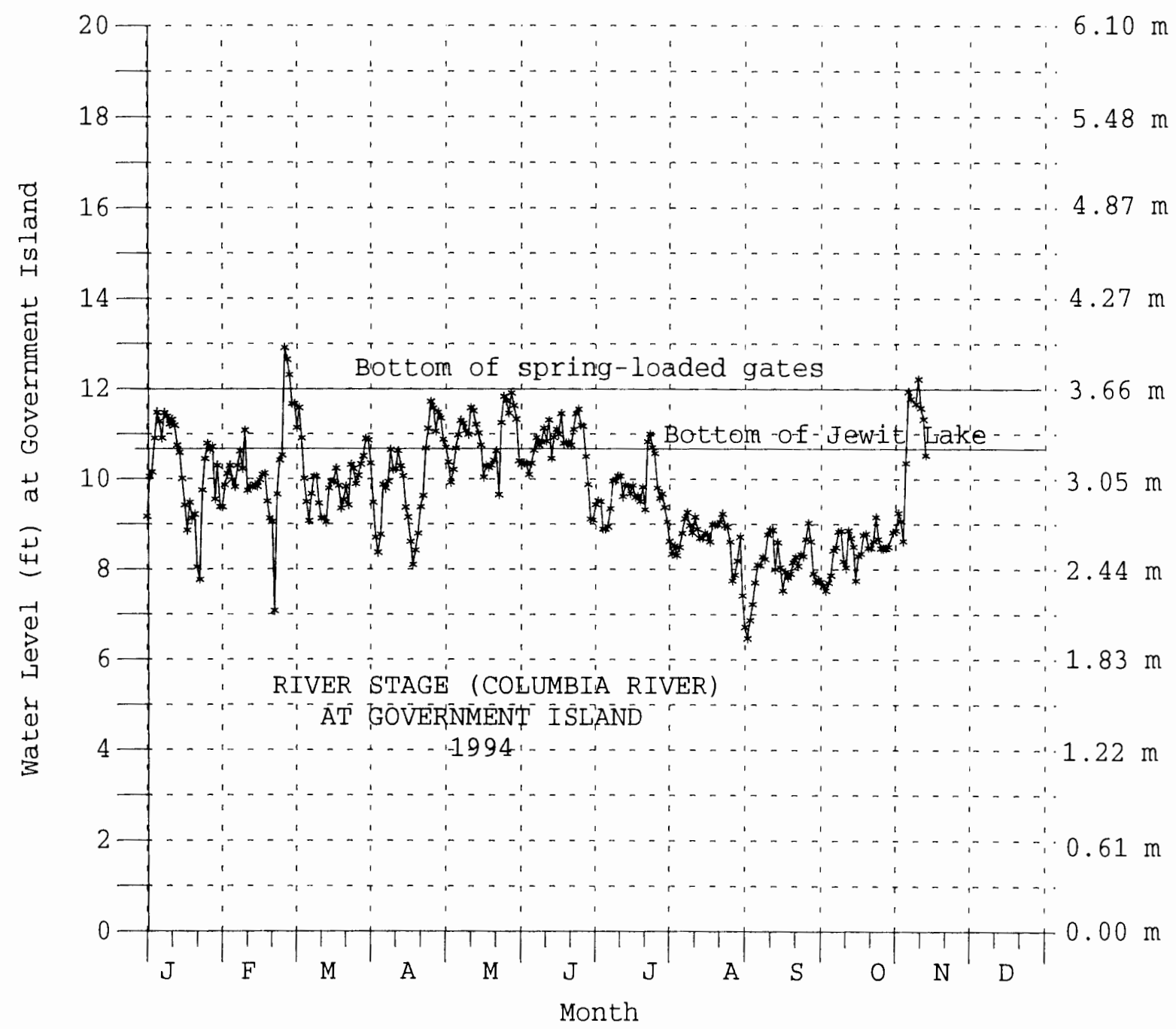

Figure 11. River stage at Government Island in 1994. 


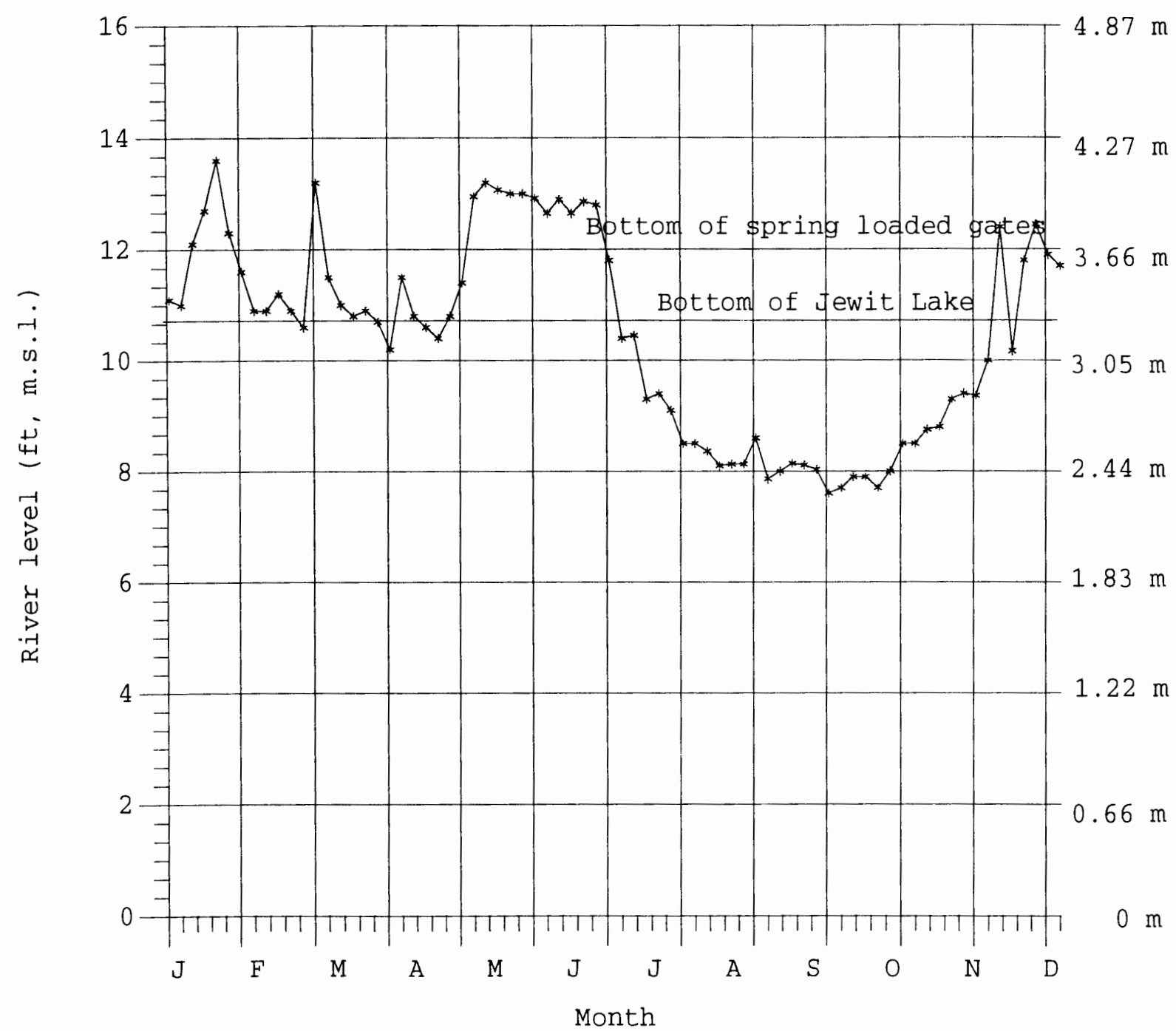

Figure 12. Mean Columbia River elevation at Government Island 1973-1980. 


\section{Water Level Monitoring}

Water levels throughout the study area were monitored in order to observe fluctuations during the study. Each monitoring point was surveyed to a $0.03 \mathrm{~m}(0.1 \mathrm{ft})$ accuracy so water elevations would be known at each point. Locations of monitoring points are shown in Figure 13. From these measurements, variations in water levels and the direction of slope of the water table can be determined. Water level measurements were compared to Columbia River levels, precipitation, and evapotranspiration so that the processes responsible for water table fluctuation could be assessed.

Water level measurements were also used to approximate the hydraulic conductivity of the sediments in Southeast Pond. Table I records the water depths in Southeast Pond between October 23, 1993 and October 30, 1993. Southeast Pond water levels decreased at an average rate of $0.12 \mathrm{ft} /$ day between October 23, 1993 and October 30, 1993. The infiltration rate is $3.0 \mathrm{~cm} /$ day 10.10 $\mathrm{ft} /$ day) when an evapotranspiration rate of $0.61 \mathrm{~cm} /$ day (0.02 ft/day) is subtracted from the rate at which water levels decreased. The evapotranspiration rate of 0.61 $\mathrm{cm} /$ day $(0.02 \mathrm{ft} /$ day) was measured at a weather station in Vancouver, Washington. Using Darcy's law

$$
V_{h}=-K(\delta h / \delta I)
$$


where $v_{h}$ is the specific discharge, $\delta \mathrm{h} / \delta \mathrm{l}$ is the hydraulic gradient, and $\mathrm{K}$ is the hydraulic conductivity, the hydraulic conductivity of the sediments underlying Southeast Pond can be approximated from infiltration rates if the hydraulic gradient remains constant. The hydraulic gradient present at Government Island will remain constant if Columbia River levels remain constant. Figure 10 shows that Columbia River levels remained at a nearly constant level of $2.7 \mathrm{~m} \mathrm{(8.9} \mathrm{ft)} \mathrm{in} \mathrm{August,} \mathrm{September,} \mathrm{and} \mathrm{October}$ of 1993. The hydraulic gradient at Government Island is determined by subtracting the head of the Columbia River $(2.7 \mathrm{~m}, 8.9 \mathrm{ft})$ from water levels in Southeast Pond (3.7 $\mathrm{m}$, $12 \mathrm{ft})$. By approximating the bottom elevation of the confining unit underneath Southeast Pond at $1.6 \mathrm{~m}$ (5 ft), the thickness of the confining unit is approximately $2.1 \mathrm{~m}$ ( $7 \mathrm{ft})$. By substituting values of $0.9 \mathrm{~m}(3.1 \mathrm{ft})$ for $\delta \mathrm{h}$ and $2.1 \mathrm{~m}$ (7 ft) for $\delta 1$, the hydraulic gradient is 0.45 . By substituting 0.45 for $\delta \mathrm{h} / \delta 1$ in Darcy's law, the hydraulic conductivity is $6.7 \mathrm{~cm} /$ day $(0.22 \mathrm{ft} /$ day $)$.

Table II contains water level elevations at monitoring points in the mitigation site during 1994. Figure 13 shows the location of these monitoring points. Values in Table II are given in feet, m.s.l. If no water was present at a monitoring point, the point is labeled 'dry'. If the water level was not measured, the point is 
Table I

Approximate water depths in Southeast pond between October $23 r d$ and October 30 th, 1993.

Date

10-23-93

$10-26-93$

$10-27-93$

$10-28-93$

$10-30-93$
Water Depth

$\begin{array}{rl}\frac{\mathrm{Cm}}{25.4} & \text { in } \\ 10.2 & 10 \\ 6.4 & 2.5 \\ 5.0 & 2 \\ 1.3 & 0.5\end{array}$

labeled '?'. If a monitoring point had not been established at the date shown, ' $\mathrm{n} / \mathrm{a}$ ' appears in Table II. Monitoring points 11, 12, 13, 32, 33, 34, and 40 (Figure 13) are used to constrain water elevations in the Jewit Lake area. In February through June, the water elevations in the Jewit Lake area were highest in the lake, and equal to or lower than the lake level in the monitoring points surrounding Jewit Lake. At monitoring points 23, 25, and 26 (Figure 13), the water table was consistently higher than at any of the other monitoring points. Subsurface water elevations in the Jewit Lake area are not known July to November because the water table fell below the depths of all of the monitoring devices. The water monitoring devices extend $1 \mathrm{~m}$ ( $3.3 \mathrm{ft})$ below the ground surface. The location of the water table in the vicinity of southeast Pond is poorly constrained during 1994 since only the Southeast Pond staff gauge and monitoring point 20 are present in that area. 
Table II

Government Island water levels

\begin{tabular}{|c|c|c|c|c|c|c|c|c|c|c|c|c|c|}
\hline \multicolumn{14}{|c|}{ Monitoring } \\
\hline point & $2 / 6 / 94$ & $3 / 6 / 94$ & $4 / 2 / 94$ & $4 / 3 / 94$ & $4 / 10 / 94$ & $5 / 7 / 94$ & $5 / 8 / 94$ & $5 / 20 / 94$ & $6 / 10 / 94$ & $7 / 8 / 94$ & $8 / 16 / 94$ & $10 / 30 / 94$ & $12 / 21 / 94$ \\
\hline$\# 11$ & dry & 11.05 & 10.46 & 10.4 & 10.99 & dry & dry & dry & dry & dry & dry & dry & 12.88 \\
\hline$\# 12$ & $\mathrm{n} / \mathrm{a}$ & $\mathrm{n} / \mathrm{a}$ & 10.74 & 10.6 & 11.23 & $?$ & dry & dry & dry & dry & dry & dry & 12.69 \\
\hline$\# 13$ & 10.82 & 11.93 & 10.76 & 10.66 & 11.37 & ary & dry & dry & dry & dry & dry & dry & $?$ \\
\hline$\# 20$ & dry & 11.86 & dry & dry & dry & $?$ & 11.2 & dry & dry & dry & dry & dry & $?$ \\
\hline$\# 23$ & 14.26 & 15.35 & 15.18 & 15.16 & 15.59 & 13.72 & 13.6 & dry & dry & dry & dry & dry & $?$ \\
\hline$\# 25$ & $d r y$ & 16.51 & 16.29 & 16.26 & 16.97 & dry & dry & dry & dry & dry & dry & dry & 17.32 \\
\hline$\# 26$ & 15.54 & 17.48 & 16.54 & 16.5 & 17.42 & dry & dry & dry & dry & dry & dry & dry & 17.78 \\
\hline$\# 30$ & $\mathrm{n} / \mathrm{a}$ & $n / a$ & $n / a$ & $\mathrm{n} / \mathrm{a}$ & $?$ & dry & $?$ & dry & dry & dry & dry & dry & dry \\
\hline$\# 31$ & $\mathrm{n} / \mathrm{a}$ & $\mathrm{n} / \mathrm{a}$ & $\mathrm{n} / \mathrm{a}$ & $n / a$ & 12.03 & 11.76 & $?$ & 11.46 & dry & dry & dry & dry & 16.45 \\
\hline$\# \quad 32$ & $n / a$ & $\mathrm{n} / \mathrm{a}$ & $\mathrm{n} / \mathrm{a}$ & $\mathrm{n} / \mathrm{a}$ & 11.09 & $?$ & 10.34 & dry & dry & dry & dry & dry & 13.59 \\
\hline$\# 33$ & $n / a$ & $n / a$ & $\mathrm{n} / \mathrm{a}$ & $\mathrm{n} / \mathrm{a}$ & 11.35 & $?$ & 9.48 & 9.2 & dry & dry & dry & ary & 12.81 \\
\hline$\# 34$ & $\mathrm{n} / \mathrm{a}$ & $\mathrm{n} / \mathrm{a}$ & $\mathrm{n} / \mathrm{a}$ & $n / a$ & $?$ & $?$ & 12 & 12.15 & $?$ & dry & dry & dry & dry \\
\hline$\# 35$ & $\mathrm{n} / \mathrm{a}$ & $\mathrm{n} / \mathrm{a}$ & $\mathrm{n} / \mathrm{a}$ & $\mathrm{n} / \mathrm{a}$ & $?$ & $?$ & dry & dry & $?$ & dry & dry & dry & $?$ \\
\hline$\# 38$ & $\mathrm{n} / \mathrm{a}$ & $\mathrm{n} / \mathrm{a}$ & $n / a$ & $n / a$ & $\mathrm{n} / \mathrm{a}$ & $\mathrm{n} / \mathrm{a}$ & $\mathrm{n} / \mathrm{a}$ & $\mathrm{n} / \mathrm{a}$ & $\mathrm{n} / \mathrm{a}$ & dry & 5.5 & 5.5 & $?$ \\
\hline$\# \quad 39$ & $n / a$ & $\mathrm{n} / \mathrm{a}$ & $n / a$ & $n / a$ & $\mathrm{n} / \mathrm{a}$ & $\mathrm{n} / \mathrm{a}$ & $\mathrm{n} / \mathrm{a}$ & $\mathrm{n} / \mathrm{a}$ & $\mathrm{n} / \mathrm{a}$ & dry & 5.5 & dry & $?$ \\
\hline$\# \quad 40$ & $\mathrm{n} / \mathrm{a}$ & $\mathrm{n} / \mathrm{a}$ & $\mathrm{n} / \mathrm{a}$ & $n / a$ & $n / a$ & $\mathrm{n} / \mathrm{a}$ & $\mathrm{n} / \mathrm{a}$ & $\mathrm{n} / \mathrm{a}$ & $n / a$ & dry & 4 & 4.5 & 8.5 \\
\hline Jewit & dry & 11.21 & 11.67 & 11.62 & 11.66 & dry & dry & dry & dry & $d r y$ & dry & dry & 11.71 \\
\hline \multicolumn{14}{|l|}{ Lake } \\
\hline S.E. & $\mathrm{n} / \mathrm{a}$ & 13.1 & 12.67 & 12.6 & 12.85 & 12 & 12 & $?$ & dry & dry & dry & dry & $?$ \\
\hline Pond & & & & & & & & & & & & & \\
\hline
\end{tabular}




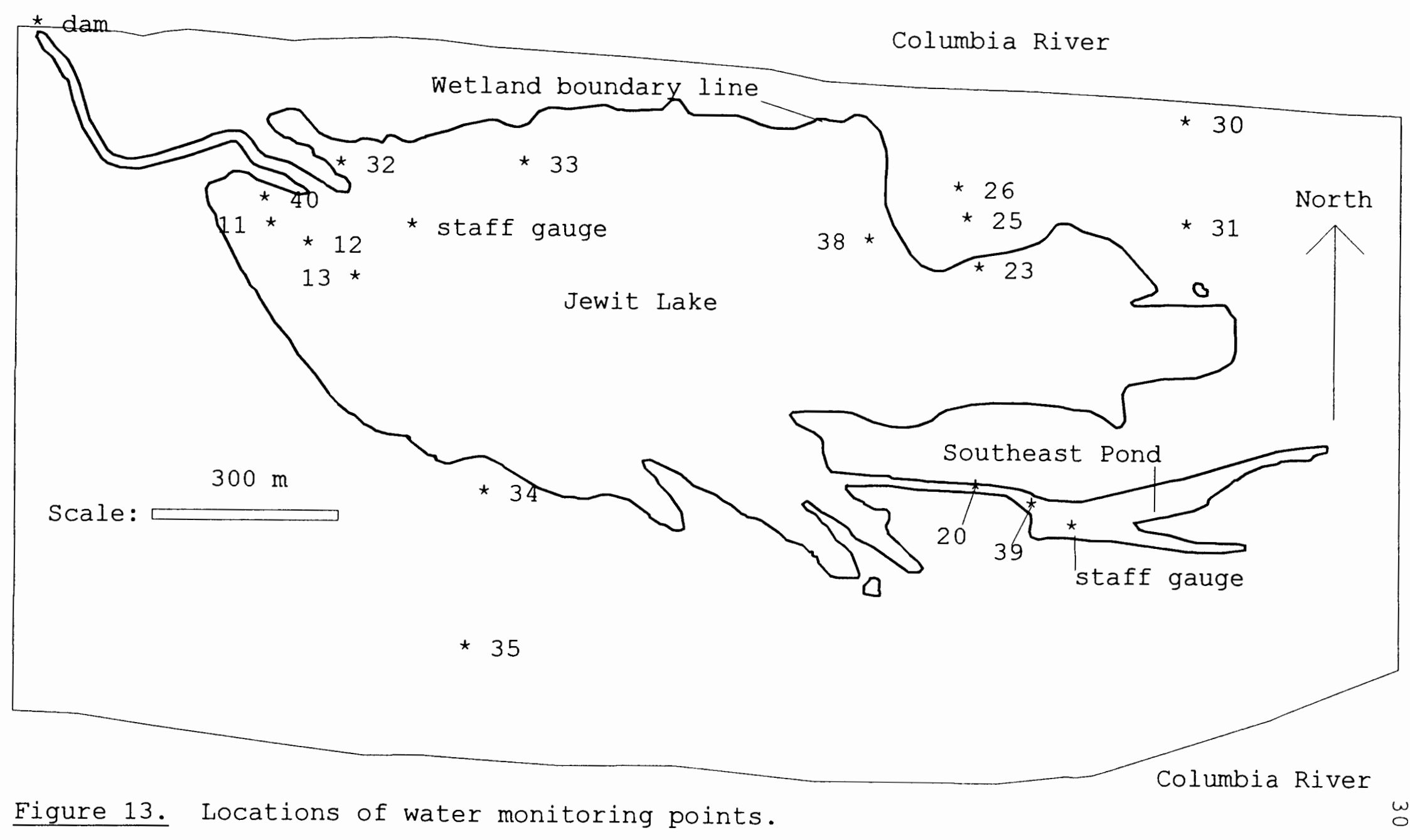


To estimate the volume of water in Jewit Lake and Southeast Pond, a topographic map (Oakley Engineering Inc., 1992) was analyzed at the $3.3,3.6,4.0,4.3$, and $4.6 \mathrm{~m}(11,12,13,14$, and $15 \mathrm{ft})$ contours. Areas within each contour were obtained using a planimeter. Volume estimates of the amount of water contained between lake levels of 3.2 and $4.6 \mathrm{~m} \mathrm{(10.5} \mathrm{and} 15.0 \mathrm{ft})$ are given in Table III. The cumulative volumes of water in Jewit Lake and Southeast Pond with increasing water levels are shown in Figures 14 and 15. Figure 14 shows that the volume of water in Jewit Lake increases with lake level at a lesser rate between 3.2 and $3.6 \mathrm{~m}(10.5 \mathrm{ft}$ and $12 \mathrm{ft}$ ) than between 3.6 and $4.6 \mathrm{~m} \mathrm{(12} \mathrm{ft} \mathrm{and} 15 \mathrm{ft}$ ). This occurs because the surface area of the lake increases with lake level at a lesser rate below $3.6 \mathrm{~m}$ (12 ft) than above 3.6 $m$ (12 ft). Figure 15 shows that the volume of water in Southeast Pond increases with lake level at a greater rate between 3.6 and $4.0 \mathrm{~m} \mathrm{(12}$ and $13 \mathrm{ft}$ ) than between 4.0 and $4.6 \mathrm{~m}$ ( 13 and $15 \mathrm{ft}$ ). This occurs because the surface area of the lake increases with lake level at a greater rate below $4.0 \mathrm{~m}$ (13 ft) than above $4.0 \mathrm{~m}$ (13 ft). 
Table III

The volume of water in Jewit Lake and Southeast Pond at lake levels between 3.2 and $4.6 \mathrm{~m} \mathrm{m.s.l}$.

\section{Lake level}

$3.2 \mathrm{~m}(10.5 \mathrm{ft})$

$3.3 \mathrm{~m}(11.0 \mathrm{ft})$

$3.4 \mathrm{~m}(11.5 \mathrm{ft})$

$3.6 \mathrm{~m}(12.0 \mathrm{ft})$

$3.8 \mathrm{~m}(12.5 \mathrm{ft})$

$4.0 \mathrm{~m}(13.0 \mathrm{ft})$

$4.1 \mathrm{~m}(13.5 \mathrm{ft})$

$4.3 \mathrm{~m}$ ( $14.0 \mathrm{ft})$

$4.5 \mathrm{~m}$ (14.5 ft)

$4.6 \mathrm{~m}(15.0 \mathrm{ft})$

\begin{tabular}{c} 
Jewit Lake $\left(\mathrm{m}^{3}\right)$ \\
\hline 1290 \\
3646 \\
25195 \\
62404 \\
115560 \\
184857 \\
269139 \\
367636 \\
480440 \\
607974
\end{tabular}

Southeast Pond $\left(\mathrm{m}^{3}\right)$
350

2325

5649

9875

14707

20294

26737

\section{Flow rates through the dam}

Figure 16 shows the level of the Columbia River at Government Island from November of 1994 to February of 1995. From January 14th to January 21st, the Columbia River raised Jewit Lake $15 \mathrm{~cm}$ ( 6 in) as water flowed through the spring loaded gates on the dam. From February 1st to February 4 th and February 20 th to February 22nd, flow through the dam occurred through the spring loaded gates and the open spillway grates.

The total volume of water present in Jewit Lake at different lake levels can be used to estimate flow rates through the dam. Table IV shows the flow rates through the dam for peak events (Figure 16) in January and February of 1995. Figure 17 shows estimates of the amount of time required to fill Jewit Lake from 3.6 to $4.6 \mathrm{~m}(12$ to $15 \mathrm{ft}$ ) based on flow rates through the dam in January 


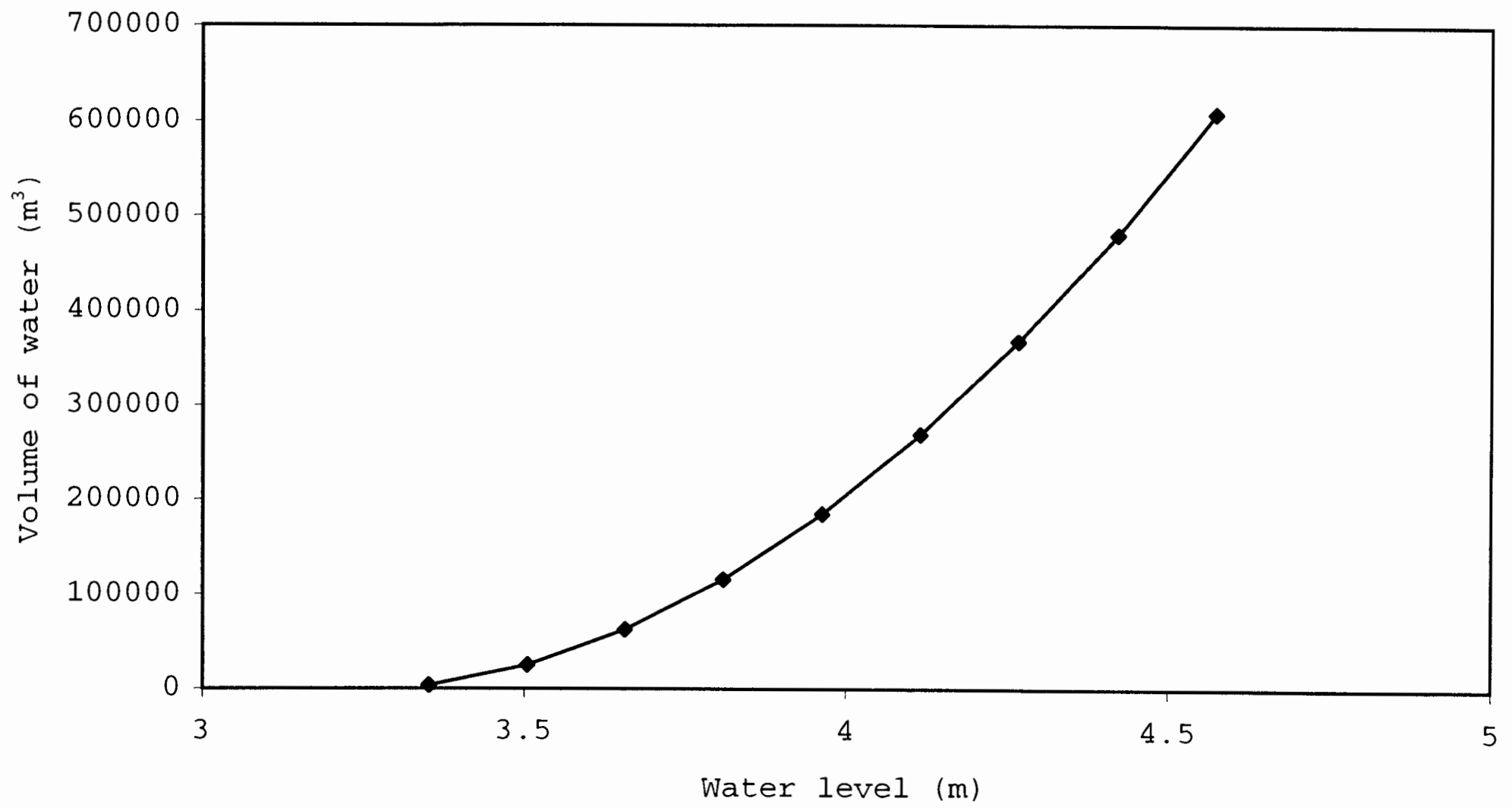

Figure 14. Volume of water in Jewit Lake at water levels between $3.2 \mathrm{~m}(10.5 \mathrm{ft})$ and $4.6 \mathrm{~m}(15.0 \mathrm{ft})$. 


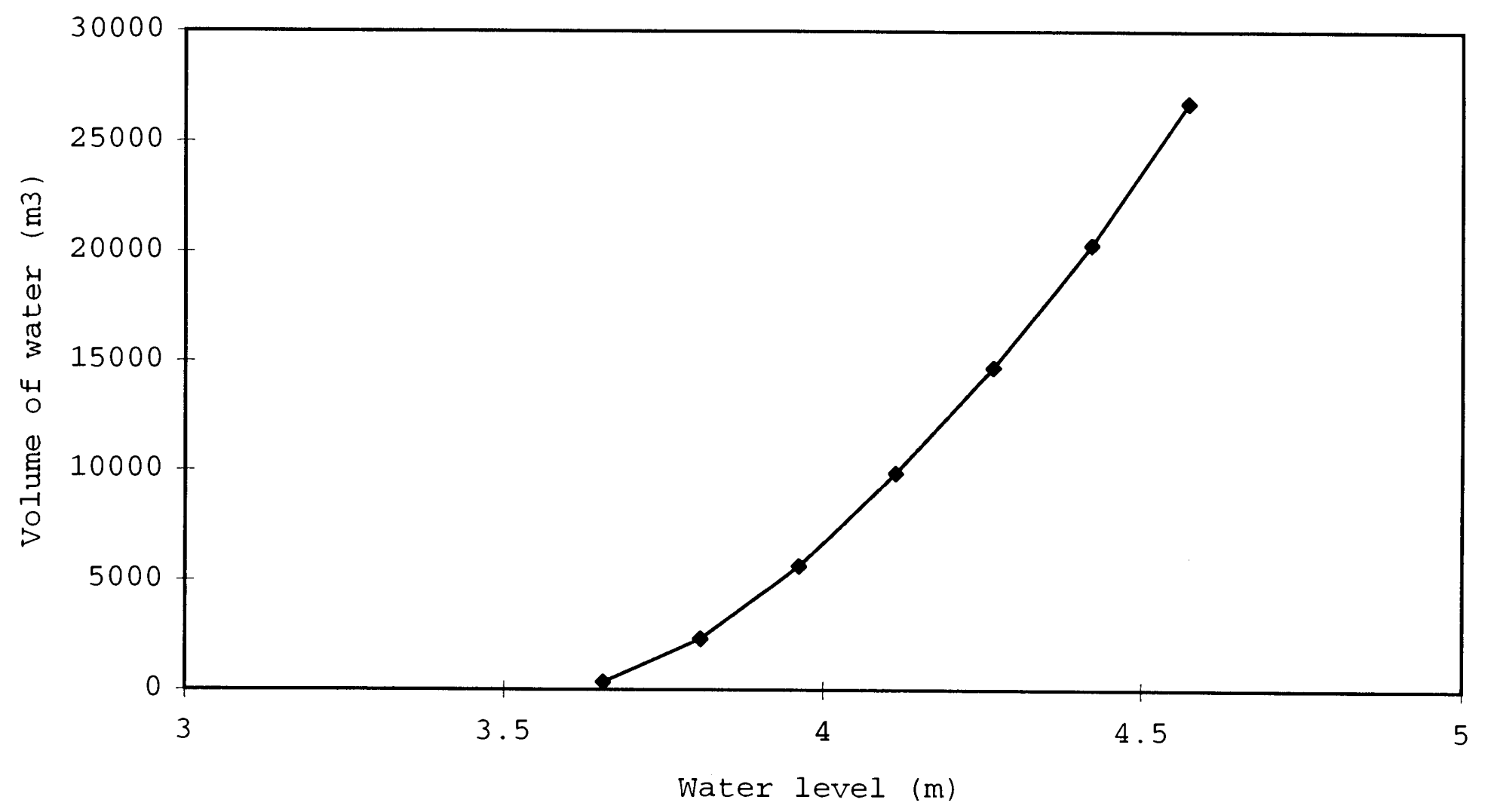

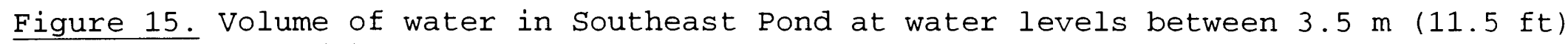
and $4.6 \mathrm{~m}(15.0 \mathrm{ft})$. 


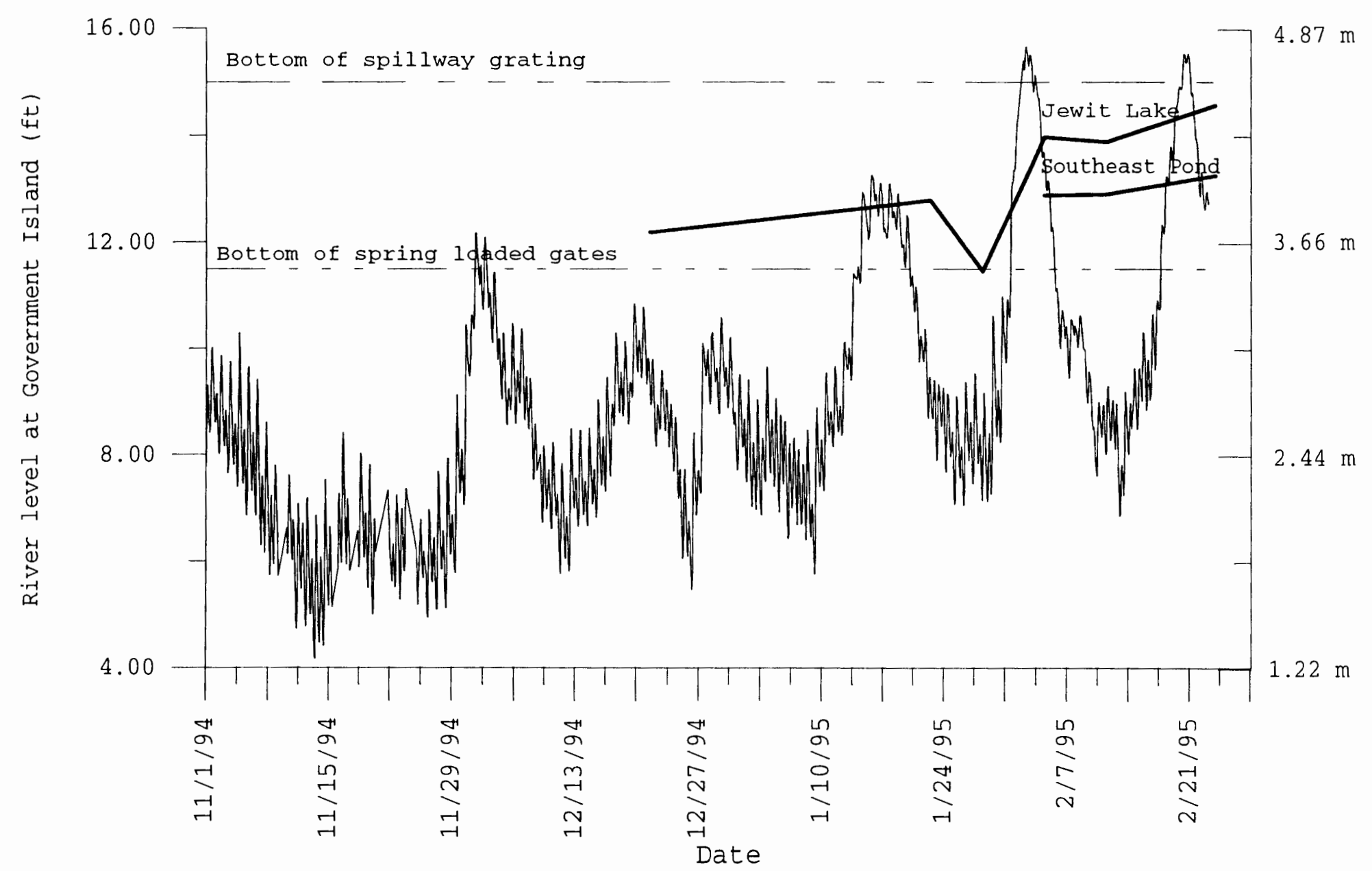

Figure 16. River level, Jewit Lake level, and Southeast Pond level from November 1, 1994 to February $21,1995$. 


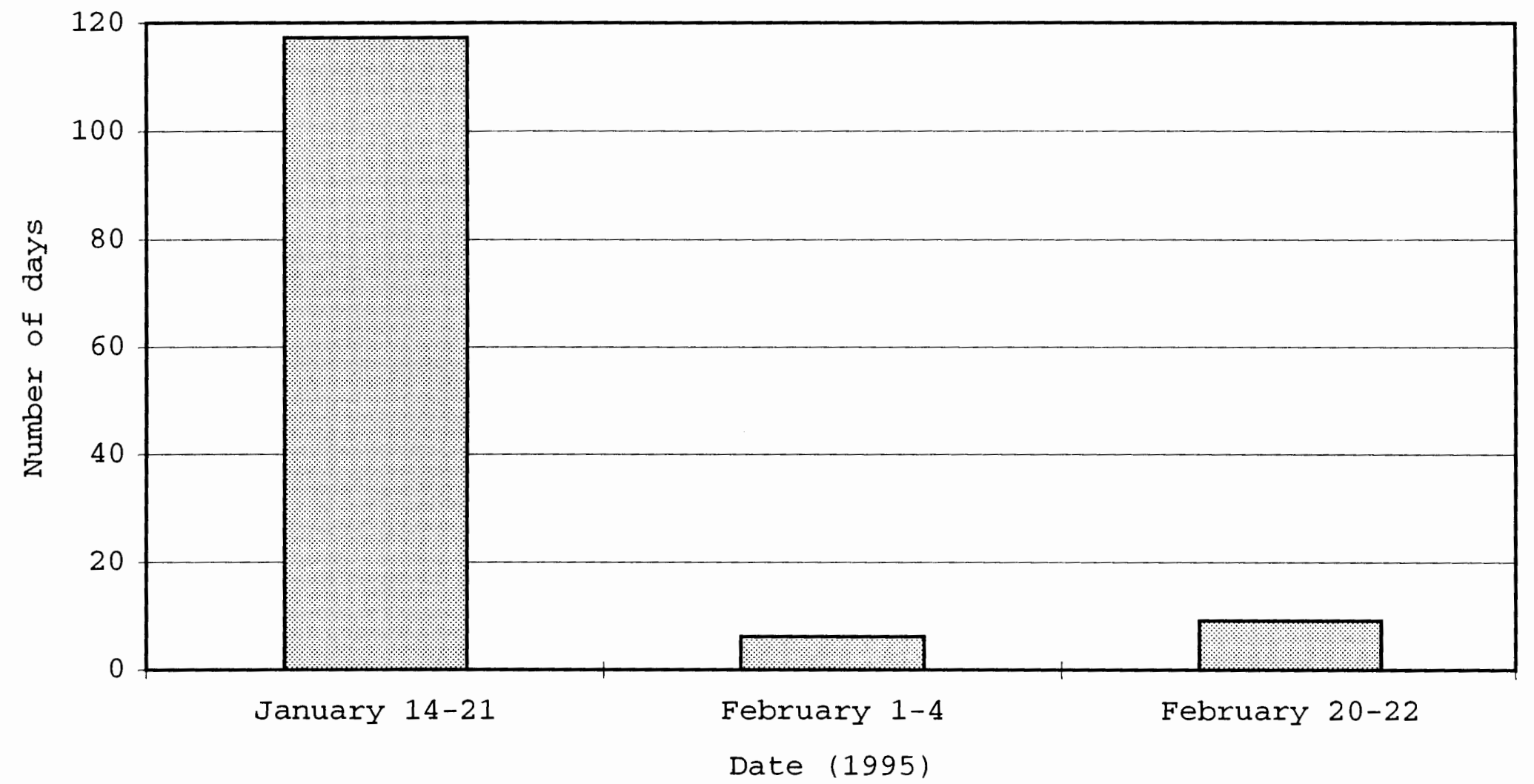

Figure 17. Time required to raise Jewit Lake from $3.6 \mathrm{~m}$ (12 ft) to $4.6 \mathrm{~m}$ (15 ft) based on flow rates through the dam in January and February, 1995. 
and February of 1995. Figure 17 shows that less time is required to fill Jewit Lake as flow rates through the dam increase.

Table IV

Rates of flow through the dam as water flowed into Jewit Lake in January and February, 1995.

Flow rate through the

$\frac{\text { Date of peak event }}{1-14 \text { to } 1-21} \frac{\left(\text { dam }\left(\mathrm{m}^{3} / \text { day }\right)\right.}{1363}$

$2-1$ to $2-4$

$2-20$ to $2-22$
25265

22084
Lake levels (m)

3.7 to 3.9

3.6 to 4.3

4.3 to 4.4

\section{Climatological Data}

Daily precipitation and evapotranspiration values were obtained from a weather station in east Vancouver, Washington. The weather station is located approximately $3 \mathrm{~km}$ (2 $\mathrm{mi})$ north of the study area. The weather station is operated by the Irrigation Management District of Vancouver. Daily precipitation was also obtained from the National weather Service at Portland International Airport, approximately $8 \mathrm{~km}$ ( $5 \mathrm{mi}$ ) west of the study area. Daily precipitation in 1993 and 1994 was averaged between the Vancouver weather station and the National Weather Service station to determine precipitation on Government Island. Historical average monthly precipitation for the Portland area was obtained from the National Weather Service. Monthly 1993 and 1994 precipitation and 
historical monthly average precipitation are shown in Figures 18 and 19. The Vancouver weather station has an incomplete precipitation record for some months. Precipitation data are necessary for this study because precipitation onto Government Island adds water into Jewit Lake and Southeast Pond.

Evapotranspiration rates are necessary to estimate evapotranspiration loss. Figure 20 shows monthly 1993 , 1994, and average actual evapotranspiration at the Vancouver weather station. Average evapotranspiration was determined by averaging evapotranspiration data collected from 1991 to 1994. Figure 20 indicates that evapotranspiration rates were below average during the summer months of 1993 and above average during the summer months of 1994. The data collected from the Vancouver weather station for the study do not contain the parameters necessary to determine the method used by the weather station to determine evapotranspiration by the methods given in Dunne and Leopold (1978) and Chow (1964). The Vancouver weather station reports measurements of relative humidity, wind velocity, solar radiation, precipitation, minimum daily temperature, maximum daily temperature, and evapotranspiration. The Thornthwaite method of determining evapotranspiration (Chow, 1964) and Penman's energy balance of small pans and shallow lakes 


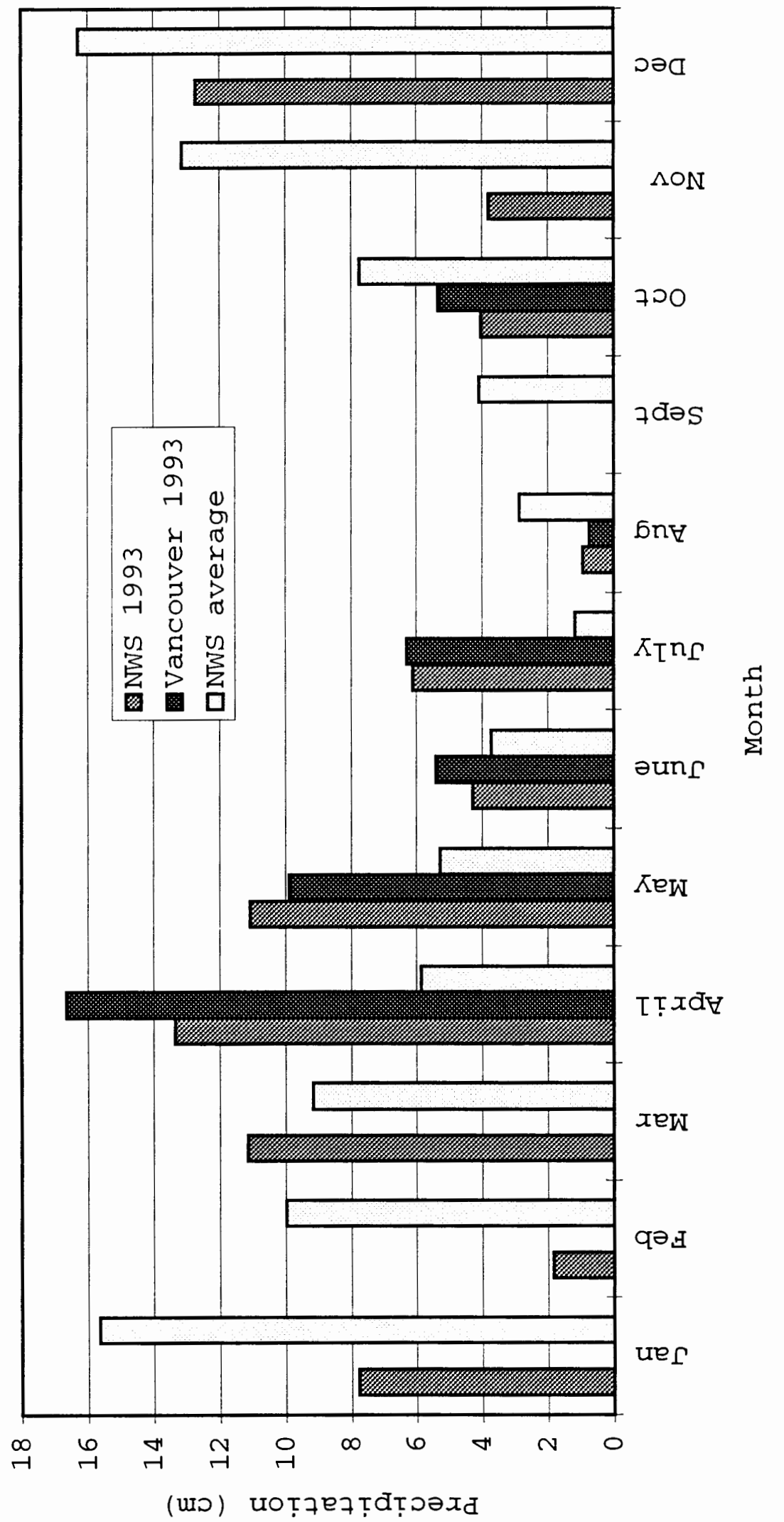

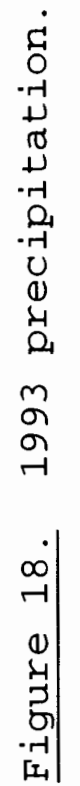




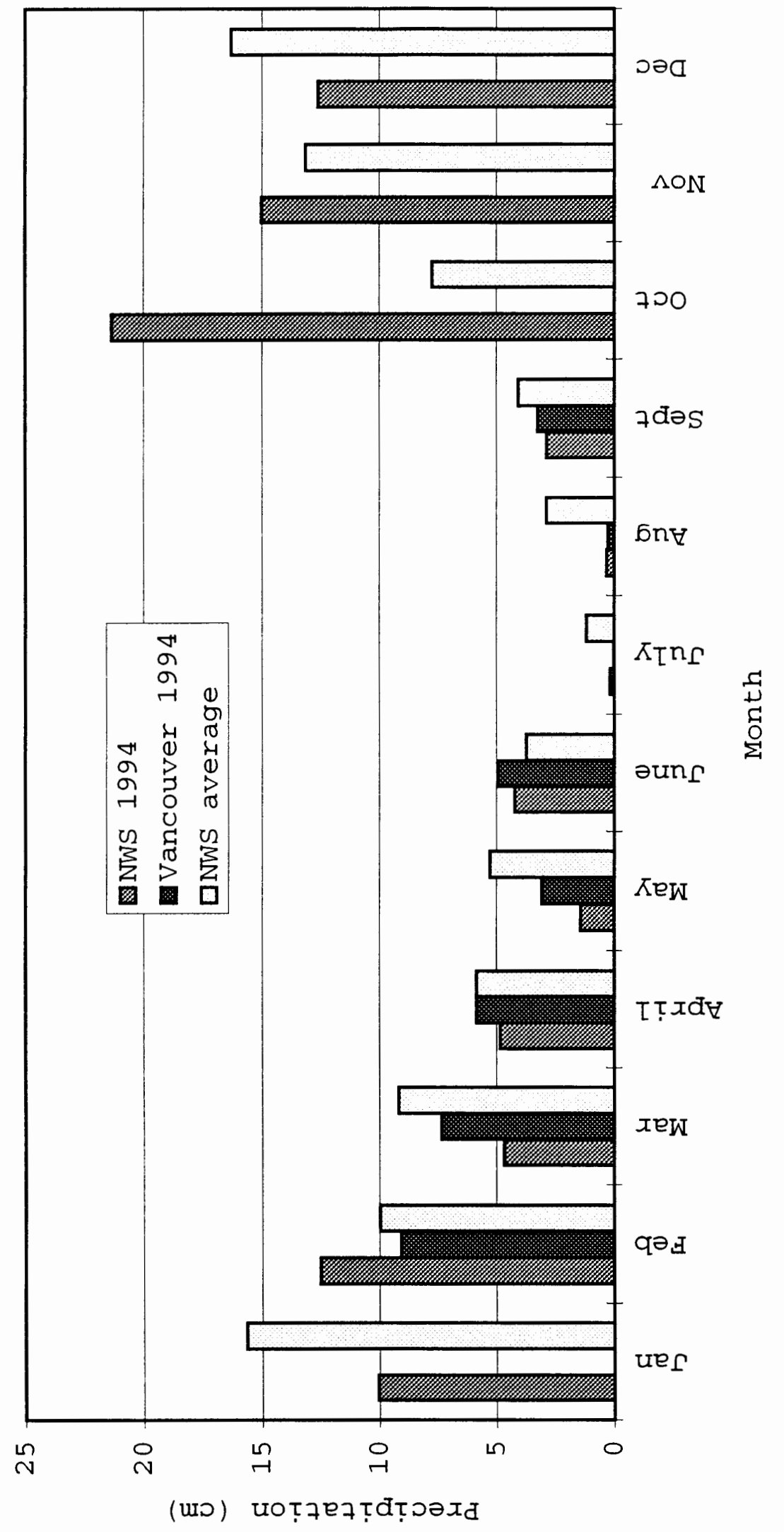

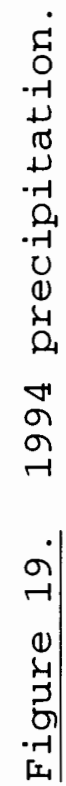




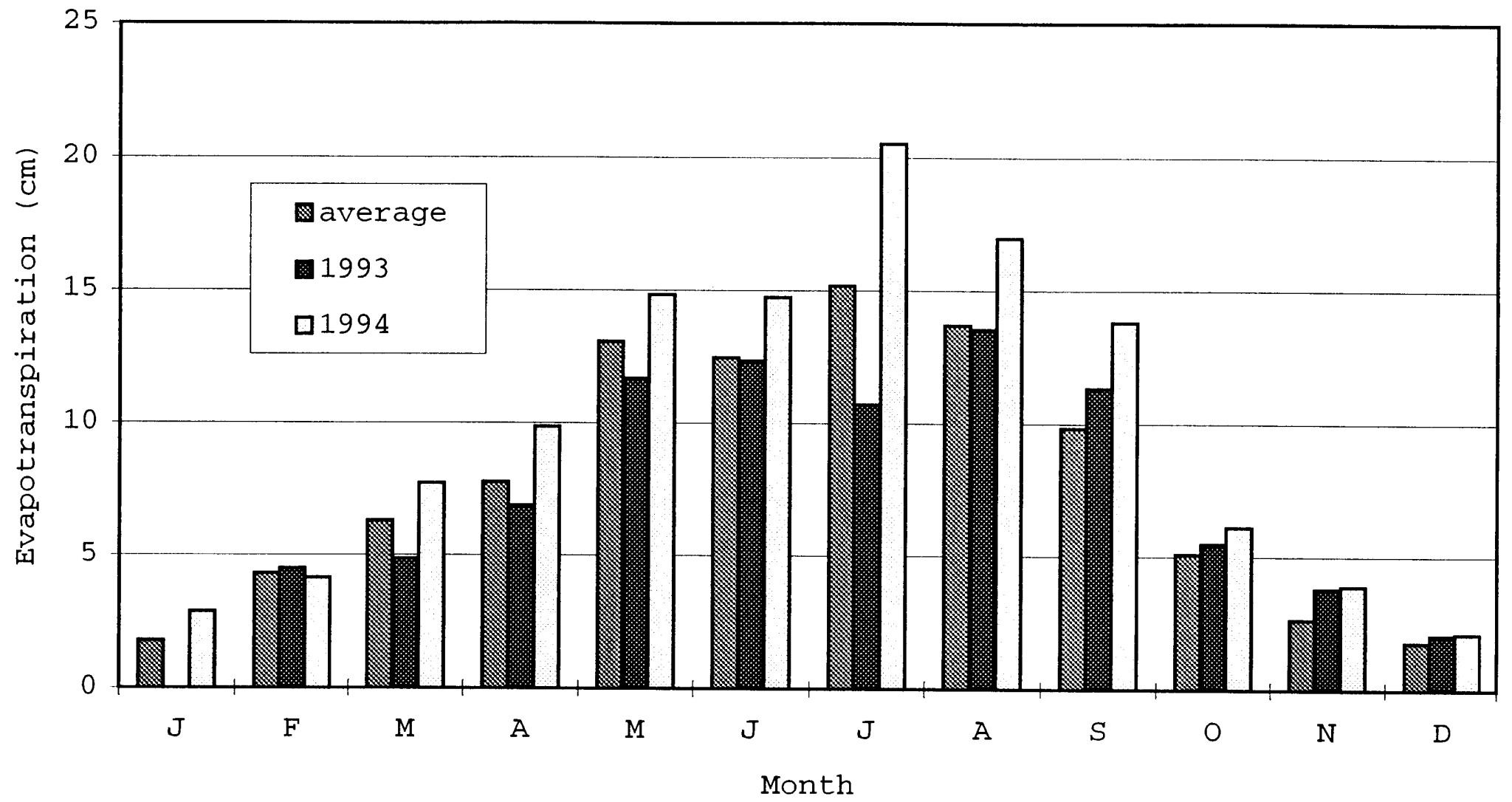

Figure 20. 1993, 1994, and average monthly evapotranspiration in Vancouver, Washington. 
method of calculating evaporation (Dunne and Leopold, 1978) are the methods that can be used to estimate water loss to the atmosphere using the data collected from the Vancouver weather station. The formula

$$
U=1.6 *(10 * t / T E)^{a}
$$

where $U$ is evapotranspiration in cm/day, $t$ is mean monthly temperature $\left({ }^{\circ} \mathrm{F}\right), \mathrm{TE}$ is Thornthwaite's temperature efficiency index, and $a$ is a heat index coefficient, is used to calculate evapotranspiration using the Thornthwaite method. The values obtained from calculations using the Thornthwaite method are approximate because the $t$ and $\mathrm{TE}$ parameters require mean daily and monthly temperatures, respectively. Mean temperatures were estimated by averaging daily maximum and minimum temperatures. The formula

$$
E_{0}=\left[(\boldsymbol{\delta} / \lambda) H+E_{a}\right] /(\boldsymbol{\delta} / \lambda)+1
$$

where $E_{0}$ is the evaporation rate in $\mathrm{cm} / \mathrm{day}, \delta / \lambda$ is Penman's dimensionless parameter for various temperatures, $\mathrm{H}$ is net radiation in units of $\mathrm{cm} / \mathrm{day}$, and $\mathrm{E}_{\mathrm{a}}$ is a term describing the contribution of mass transfer to evaporation, is used to calculate evaporation. Penman's dimensionless parameter for various temperatures 
represents a function relating windspeed, vapor pressure of the water surface, and vapor pressure of the air to evaporation rate. The terms $\delta$ and $\lambda$ are not defined in Dunne and Leopold (1978). Figure 21 shows evapotranspiration reported from the Vancouver weather station, evapotranspiration calculated using the Thornthwaite equation from data collected at the Vancouver weather station, and evaporation at the Vancouver weather station for selected days in June of 1994. Figure 21 indicates that evapotranspiration rates were higher than lake evaporation rates for the days shown in Figure 21. Figure 21 shows that calculations of evapotranspiration using the Thornthwaite method are consistently higher than calculations of evapotranspiration by the Vancouver weather station. Values for evapotranspiration reported by the Vancouver weather station were used to represent evapotranspiration on Government Island.

\section{Sediment Particle Size Analysis}

Samples were selected for particle size analysis based on field observations of sediment in soil pits, during bucket auger excavations, and during the installation of water monitoring devices. Observations were made at depths of 1.0 to $3.2 \mathrm{~m} \mathrm{(3} \mathrm{to} 10 \mathrm{ft})$, depending on the instrument used to expose the subsurface. 


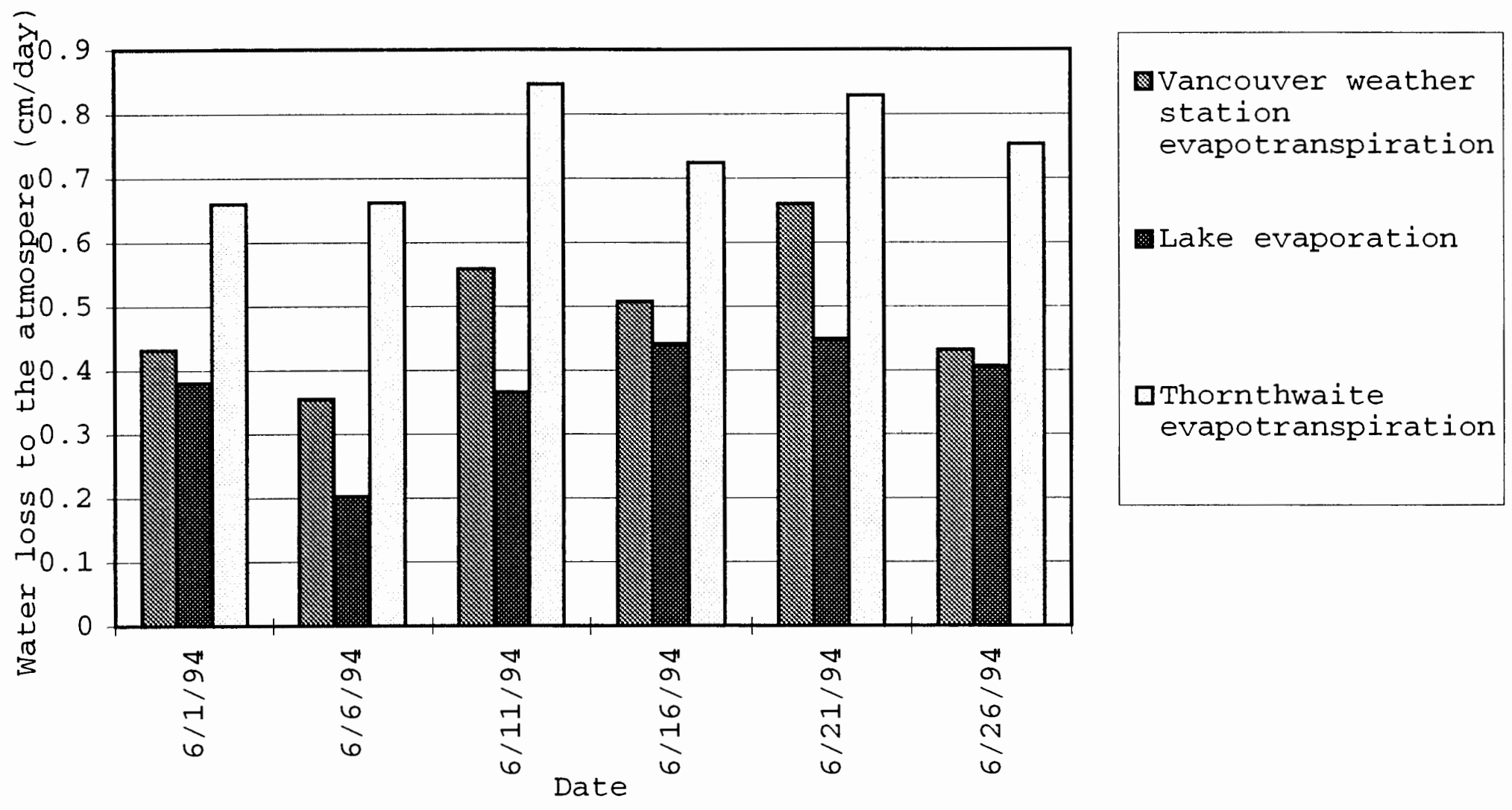

Figure 21. Evapotranspiration and lake evaporation for selected days in June, 1994. 
On the basis of visual inspection, the finest grain-size fraction at each site was sampled since vertical groundwater flow is controlled by the lowest conductivity layer. Locations of sampling sites are shown in Figure 22. Stratigraphic columns at the sampling sites and the location in the stratigraphic column where the sample was collected are given in Appendix 4. Sampling sites were selected to assess the variability in the grain-size distribution of the low conductivity layers and to determine whether the low conductivity layers had a grainsize distribution that could be related to topography or a geomorphic feature. Samples 1, 8, 9, and 15 were collected from the nonpersistent emergent wetland at sites

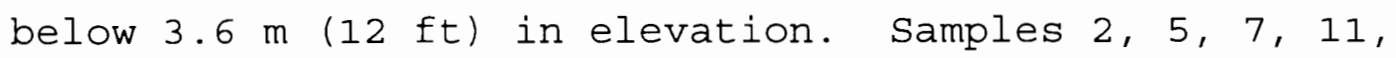
12, and 14 were collected from the persistent emergent wetland at sites between 3.6 and $4.9 \mathrm{~m}$ (12 and $16 \mathrm{ft}$ ) in elevation. Samples 3,4, 6, 10, and 13 were collected outside the wetland area. Sediments were analyzed using the hydrometer method of Day (1965). The percentages of sand, silt, clay, and colloids/organic matter are shown in Table V. The Udden-Wentworth grain size scale for clastic sediments was used to define the size ranges for the sand, silt, and clay. The amount of organic matter/colloids were not determined experimentally. The cumulative percentages of sand, silt and clay were subtracted from 


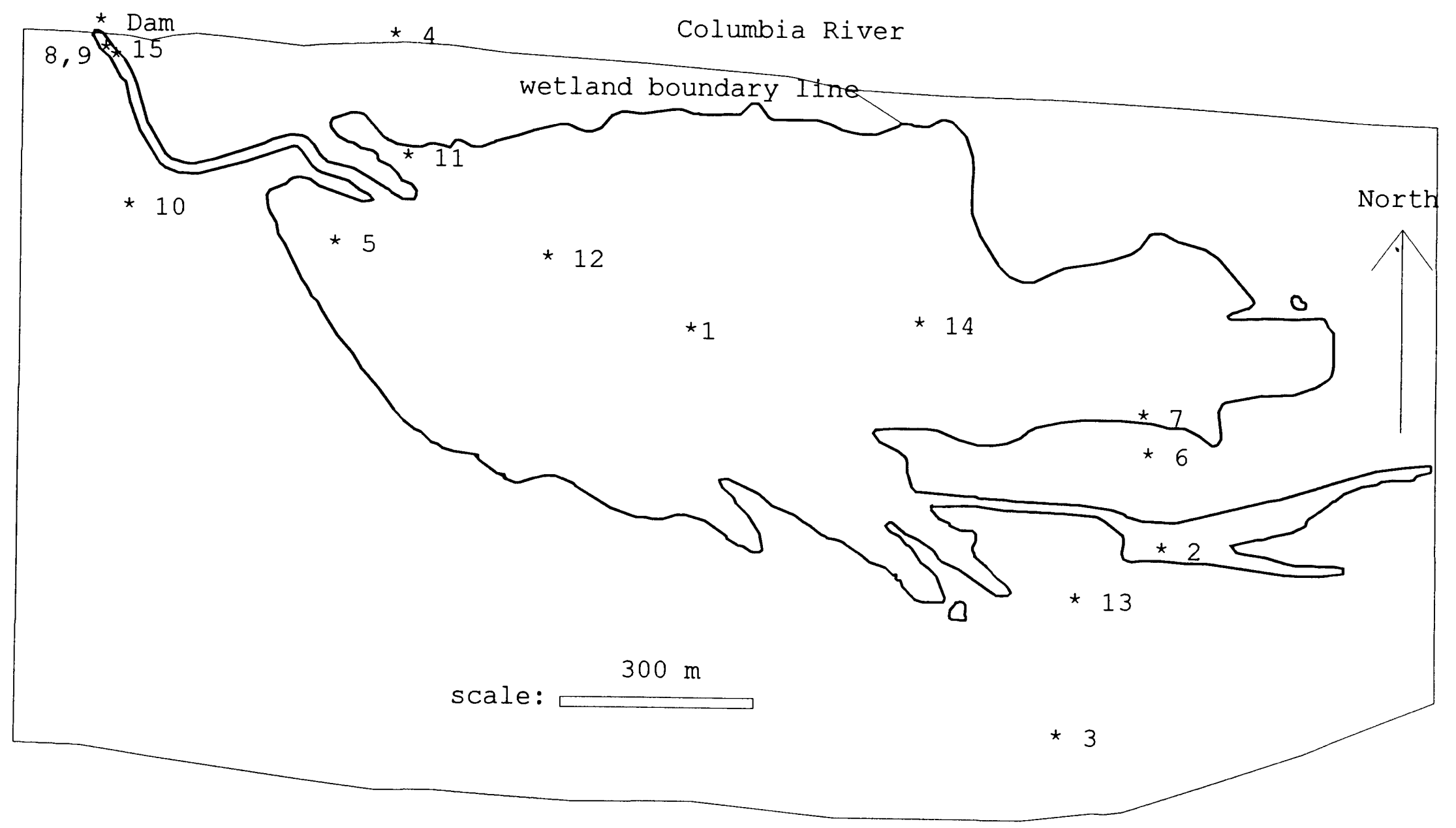

Columbia River

Figure 22. Hydrometer sampling site locations. 
100 percent of the mass of the sample to determine the percentage of organic matter/colloids. Graphs showing particle size distribution for each sample are presented in Appendix 2 .

The data indicate that a pattern in the particle size distribution relative to topography is not present. The sample from Southeast Pond (sample 2) contains 4 percent more clay than any other sample analyzed. Samples 1 through 14 are silt loams and sample 15 is a loam (Soil Survey Staff, 1992).

\section{Table V}

The grain size percentages for 15 samples collected on Government Island. Sand size material is larger than $0.0625 \mathrm{~mm}$, silt size material is between $0.0625 \mathrm{~mm}$ and $0.004 \mathrm{~mm}$, and clay size material is smaller than $0.004 \mathrm{~mm}$.

SAMPLE $\div$ SAND $\frac{\circ S I L T}{2}$ CLAY $\%$ ORGANICS/COLLOIDS Samples collected from the nonpersistent emergent wet land

\begin{tabular}{rrrrr}
\hline 1 & 1 & 74 & 14 & 11 \\
8 & 1 & 56 & 19 & 24 \\
9 & 4 & 76 & 8 & 12 \\
15 & 39 & 46 & 3 & 12
\end{tabular}

Samples collected from the persistent emergent wetland

\begin{tabular}{rllll}
\hline 2 & 1 & 67 & 23 & 10 \\
5 & 1 & 69 & 14 & 16 \\
7 & 3 & 65 & 18 & 14 \\
11 & 1 & 70 & 17 & 12 \\
12 & 0 & 64 & 16 & 20 \\
14 & 3 & 67 & 17 & 13
\end{tabular}

Samples collected from outside the wetland area

\begin{tabular}{rrrrr}
\hline 3 & 0 & 78 & 15 & 7 \\
4 & 0 & 66 & 17 & 17 \\
6 & 4 & 66 & 17 & 13 \\
10 & 4 & 72 & 14 & 14 \\
13 & 12 & 70 & 10 & 8
\end{tabular}




\section{Seismic Refraction}

Seismic refraction is used to identify boundary and density contrast conditions of subsurface units (Telford and others, 1990). In this study, seismic refraction was used to identify the depth to the water table on May 7 th and 8th, 1994. The water table is delineated from nonsaturated strata by its higher velocity signal. Five east-west transects were performed (Stations G-1, G-5, G9, G-13, and G-14) (Figure 23). Receiver distances were set at $1.0,2.0,4.0$, and $5.0 \mathrm{~m}$ spacings to obtain the optimum signals. Table VI shows the elevation of the water table based upon interpretation of the seismic refraction data and known depths of the water table from field observations at monitoring points and in soil pits. The fourth column in Table VI compares the depth to the water table determined by seismic refraction to the depth of the water table seen in soil pits and monitoring points. At each station, the water table was calculated to be deeper using seismic refraction data than was determined by visual observation of the water table in soil pits and monitoring points. Visual observation indicates that the water table is lowest in elevation in the topographically lowest areas (stations G-5, G-9, and Southeast Pond) and highest in the upland areas (G-1 and G-13). Seismic refraction data indicate that the water 


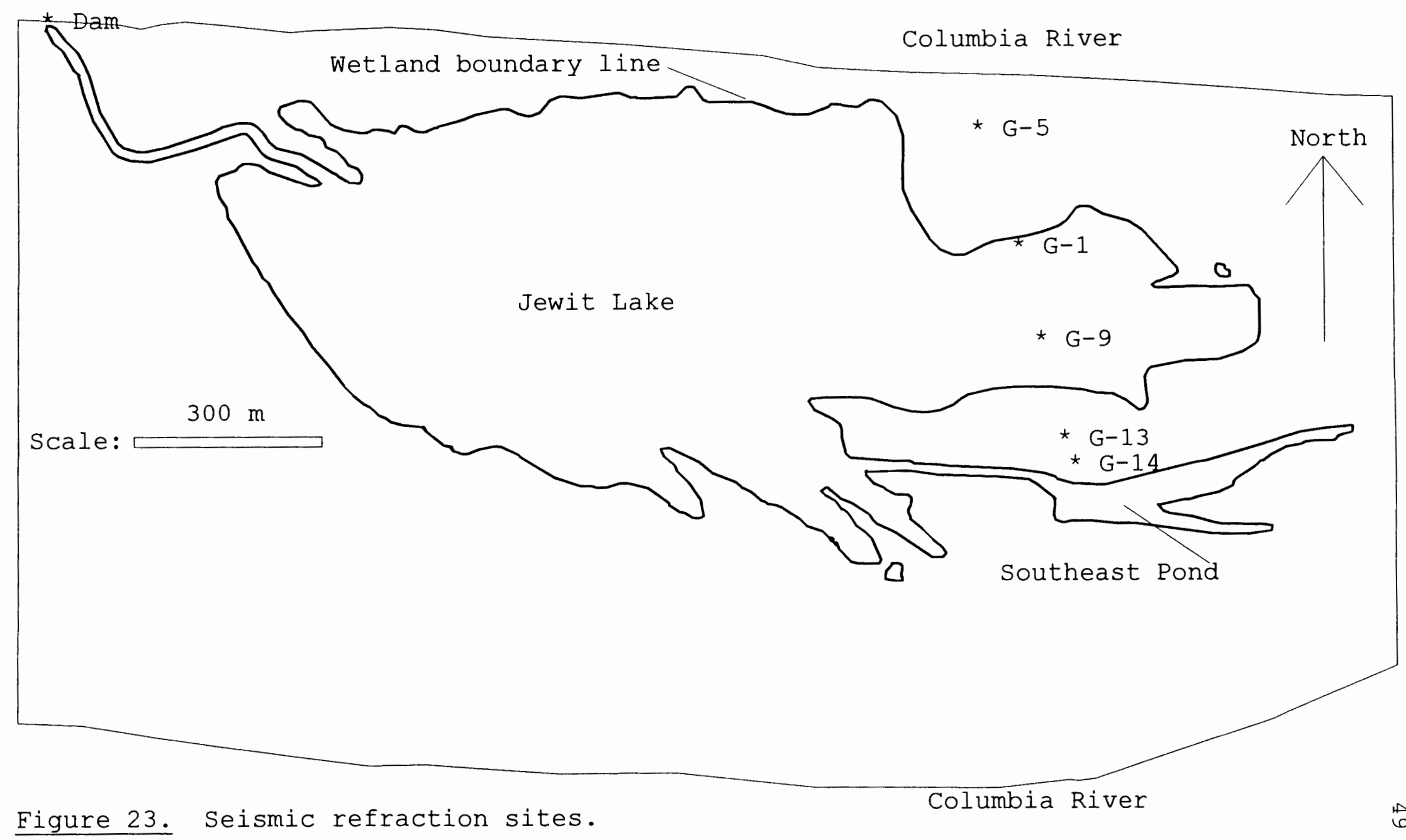


table is independent of topography with the exception of station G-9. Receiver reception time data and selected graphs of the plotted data are given in Appendix 3. Using the refraction data for station $\mathrm{G}-13$, the seismic wave velocity in the unsaturated sediments is $212.5 \mathrm{~m} / \mathrm{s}$ and the seismic wave velocity in the saturated sediments is 1562.5 $\mathrm{m} / \mathrm{s}$.

The discrepancy between seismic refraction data and visual observation of the water table may be caused by changes in the amount of water present in the sediments. Sand lenses located beneath the water table may refract the seismic signal since the amount of water present in the intergranular pore space of sand may be higher than the amount of water in the intergranular pore space of silt and clay. If sand lenses refract the seismic signals, the elevation of the water table could be inaccurate if the water table is located above the refractor. 
Table VI

Seismic Refraction on Government Island; May 7th and 8th, 1994. Distances are in meters.

\begin{tabular}{|c|c|c|c|c|}
\hline & $\begin{array}{l}\text { STATION } \\
\text { ELEVATION }\end{array}$ & $\begin{array}{l}\text { REFRACTOR } \\
\text { DEPTH }\end{array}$ & $\begin{array}{l}\text { KNOWN } \\
\text { DEPTH }\end{array}$ & $\begin{array}{l}\text { WATER TABLE } \\
\text { ELEVATION* }\end{array}$ \\
\hline $\begin{array}{l}\text { G-1 west } \\
(1-m \text { spacing })\end{array}$ & 4.9 & 1.44 & 0.710 & $3.42 / 4.11$ \\
\hline $\begin{array}{l}\text { G-5 west } \\
\text { (5-m spacing) }\end{array}$ & 6.2 & 3.34 & 1.88 & $2.88 / 4.40$ \\
\hline $\begin{array}{l}\text { G- } 5 \text { west } \\
\text { ( } 2-\mathrm{m} \text { spacing) }\end{array}$ & 6.2 & 3.23 & 1.88 & $2.99 / 4.40$ \\
\hline $\begin{array}{l}\text { G-9 spacing } \\
(5-m \text { spacing })\end{array}$ & 4.0 & 1.80 & 1.27 & $2.22 / 2.75$ \\
\hline $\begin{array}{l}\text { G-13 spacing } \\
\text { (4-m spacing) }\end{array}$ & 7.6 & 3.72 & & 3.85 \\
\hline $\begin{array}{l}\text { G-14 } \\
(4-m \text { spacing) }\end{array}$ & 5.6 & unclear & & \\
\hline $\begin{array}{l}\text { G-14 } \\
(2-\mathrm{m} \text { spacing })\end{array}$ & 5.6 & unclear & & \\
\hline Southeast Pond & & & & 3.71 \\
\hline $\begin{array}{l}\text { * In table VI, } \\
\text { of the water ta } \\
\text { subtracting the } \\
\text { elevation. The } \\
\text { field observati } \\
\text { station elevati }\end{array}$ & $\begin{array}{l}\text { there are } \\
\text { able. The } \\
\text { e depth to } \\
\text { e second nu } \\
\text { ion depths } \\
\text { ion. }\end{array}$ & $\begin{array}{l}2 \text { numbers } \\
\text { first numbe } \\
\text { the refract } \\
\text { umber is obt } \\
\text { to the wate }\end{array}$ & $\begin{array}{l}\text { showing tl } \\
\text { er is obt } \\
\text { tor from } \\
\text { tained by } \\
\text { er table. }\end{array}$ & $\begin{array}{l}\text { he elevation } \\
\text { ained by } \\
\text { the station } \\
\text { subtracting } \\
\text { from the }\end{array}$ \\
\hline
\end{tabular}

\section{Summary of factors affecting the hydrogeology of the Government Island mitigation site}

The Columbia River must reach a minimum elevation of $3.6 \mathrm{~m}$ (12 ft) for water to reach Jewit Lake through the dam and channel. Columbia River levels above $4.7 \mathrm{~m}$ (15.3 ft) fill Jewit Lake approximately 15 to 20 times faster than when Columbia River levels are below $4.7 \mathrm{~m}$ (15.3 ft) because water is able to flow through the open spillway grating and the spring loaded gates on the dam. Flooding 
of Jewit Lake is most likely to occur in December, January, May, and June. The hydraulic conductivity of the Southeast Pond sediments is approximately $6.7 \mathrm{~cm} /$ day $(0.22$ ft/day). Precipitation and evapotranspiration affect water levels on Government Island. A pattern in the particle size distribution relative to topography is not present. 


\section{GROUNDWATER MODELING \\ GROUNDWATER MODEL DESIGN}

MODFLOW, a groundwater modeling program developed by the U.S. Geological Survey in 1976 (MCDonald and Harbaugh, 1984), was used to simulate the hydrology of Government. Island. PREMOD, a preprocessor for MODFLOW, was used to enter all data into the groundwater model. A 15 node by 10 node matrix (Figure 24) was used to represent the study area. Each node is $152.4 \mathrm{~m}$ by $152.4 \mathrm{~m}$ (500 ft by $500 \mathrm{ft}$ ), covering $23,225 \mathrm{~m}^{2}\left(250,000 \mathrm{ft}^{2}\right)$.

Stratigraphic representation in the groundwater model

The groundwater model was designed as a 4 layer problem, with a confining unit overlying an aquifer. Layers 1, 2, and 3 represent the confining unit and Jewit Lake and Southeast Pond respectively; layer 4 represents the aquifer. Figure 25 is a schematic diagram of the groundwater model design. The thickness of the confining unit was approximated using a $0.61-\mathrm{m}(2-\mathrm{ft})$ contour map of the site (SRI, 1991b). Areas with higher elevations are assumed to have a thicker confining unit than areas at lower elevations. Layers 1 and 2 were designed to accomodate fluctuations in the area of Jewit Lake with changes in lake levels. At elevations above $3.6 \mathrm{~m}$ (12 ft), Jewit Lake is represented by 31 nodes (Figure 26). At elevations between 3.3 and $3.6 \mathrm{~m}$ (11 and $12 \mathrm{ft}$ ), Jewit 


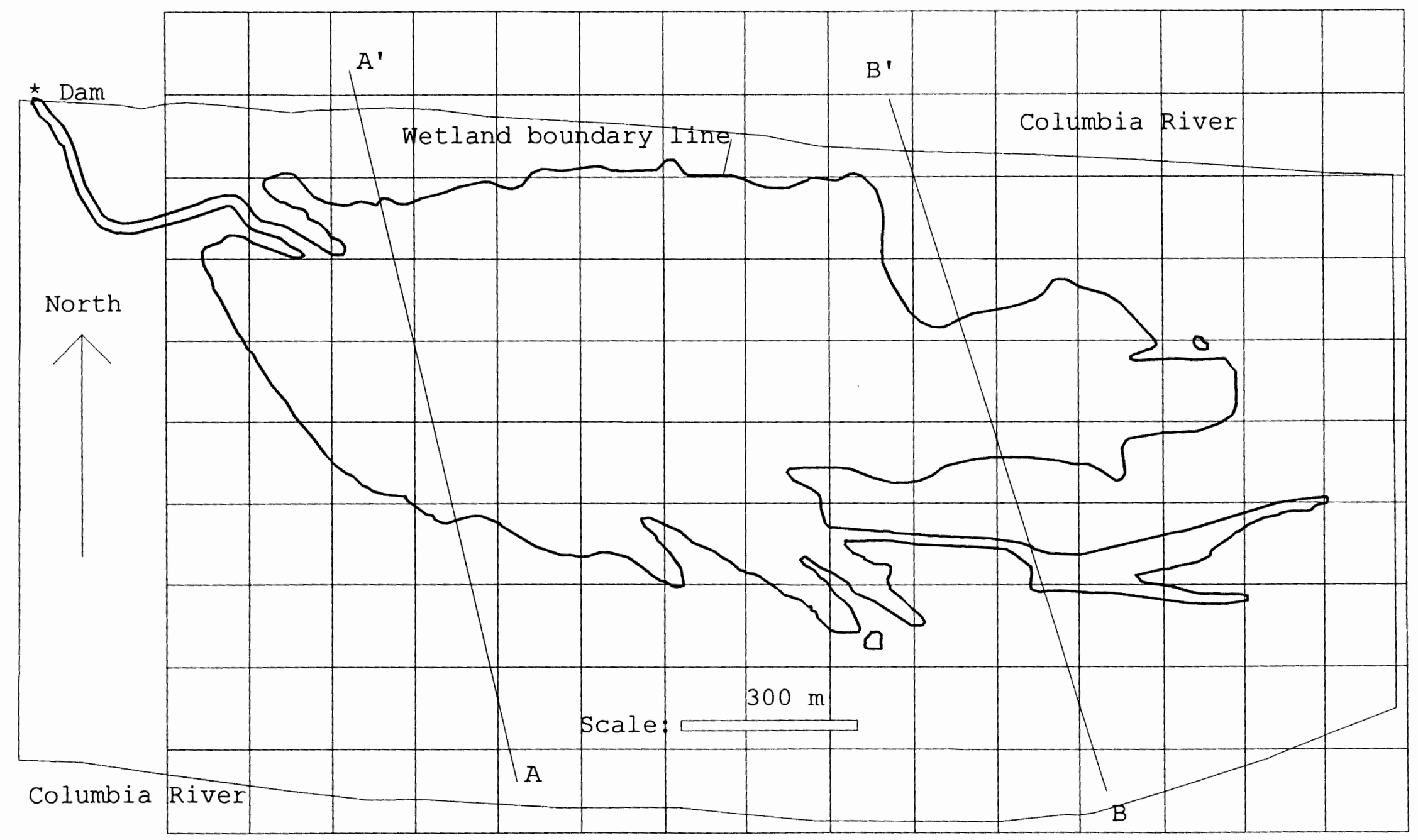

Figure 24. MODFLOW node grid. Each node is $152 \mathrm{~m}$ by $152 \mathrm{~m}$ (500 ft by $500 \mathrm{ft}$ ). Lines $\overrightarrow{A-A^{\prime}}$ and $B^{\prime}-B^{\prime}$ represent cross section (Figures 30 and 31 ) locations. 

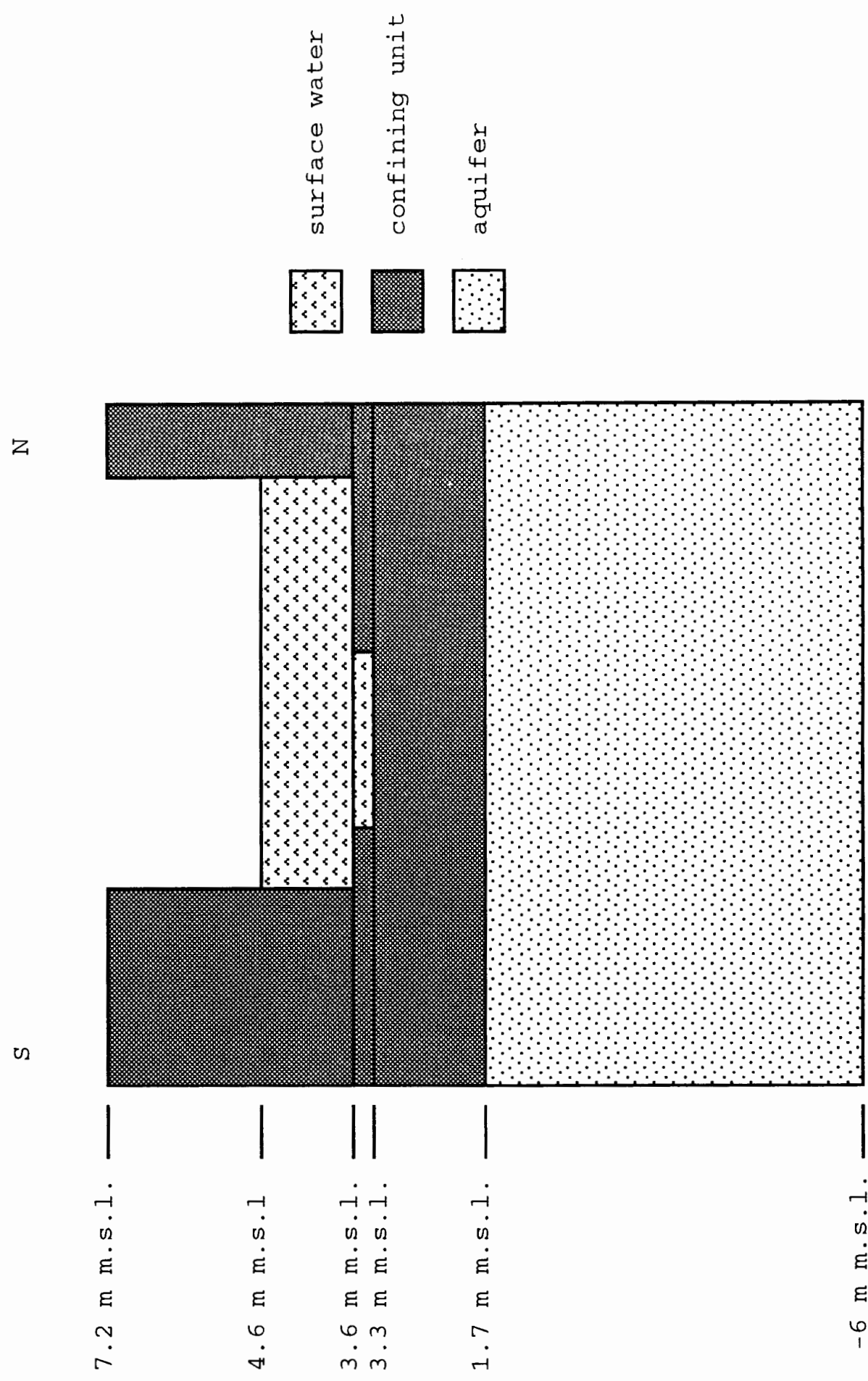

3
0
0
0
0
0
0

号

D 


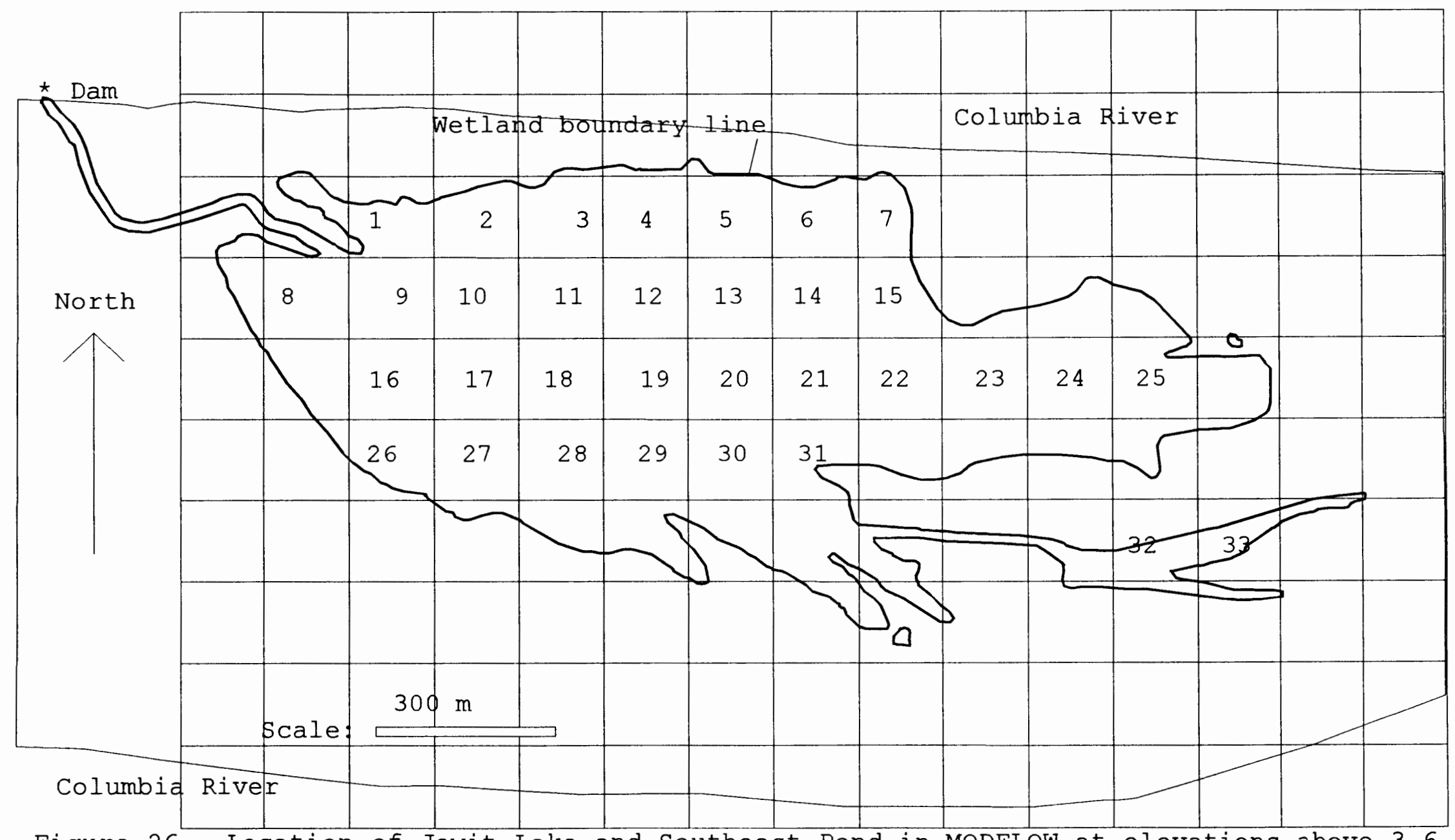

Figure 26. Location of Jewit Lake and Southeast Pond in MODFLOW at elevations above 3.6 $\mathrm{m}(12 \mathrm{ft})$. Numbers represent nodes containing Jewit Lake and Southeast Pond in MODFLOW above $3.6 \mathrm{~m}(12 \mathrm{ft})$. 
Lake is present in 7 nodes (Figure 27). Southeast Pond is represented by 2 nodes at all water levels. Nodes that fall partially within the wetland boundary line were included or omitted from the lake area based on elevation. Nodes containing elevations predominantly below $4.9 \mathrm{~m}$ (16 ft) in elevation were included in the lake area. Nodes containing elevations predominantly above $4.9 \mathrm{~m}$ (16 ft) in elevation were not included in the lake area. Surface water is represented in a node as an unconfined aquifer with 100 percent porosity and a hydraulic conductivity of $30,400 \mathrm{~m} /$ day $\left(10^{6} \mathrm{ft} /\right.$ day $)$. This hydraulic conductivity value was used because PREMOD recommends that hydraulic conductivity values not exceed $30,400 \mathrm{~m} /$ day $\left(10^{6} \mathrm{ft} /\right.$ day $)$. The remaining nodes in layers 1 and 2 have the same hydraulic conductivities as layer 3 .

Layer 3 is a heterogeneous confining unit composed of silt and clay layers, sand lenses, and a one node coarse-grained sand and gravel deposit. The unit has thicknesses of 1.7 to $6.1 \mathrm{~m}$ (5 to $20 \mathrm{ft}$ ), depending on the elevation of the land surface. Since layers in MODFLow cannot overlap vertically, variations in thickness within a layer must be controlled mathematically. This is done in MODFLOW using the VCONT parameter. VCONT is defined as the hydraulic conductivity divided by the thickness of the layer. By varying the VCONT parameter, the layer is 


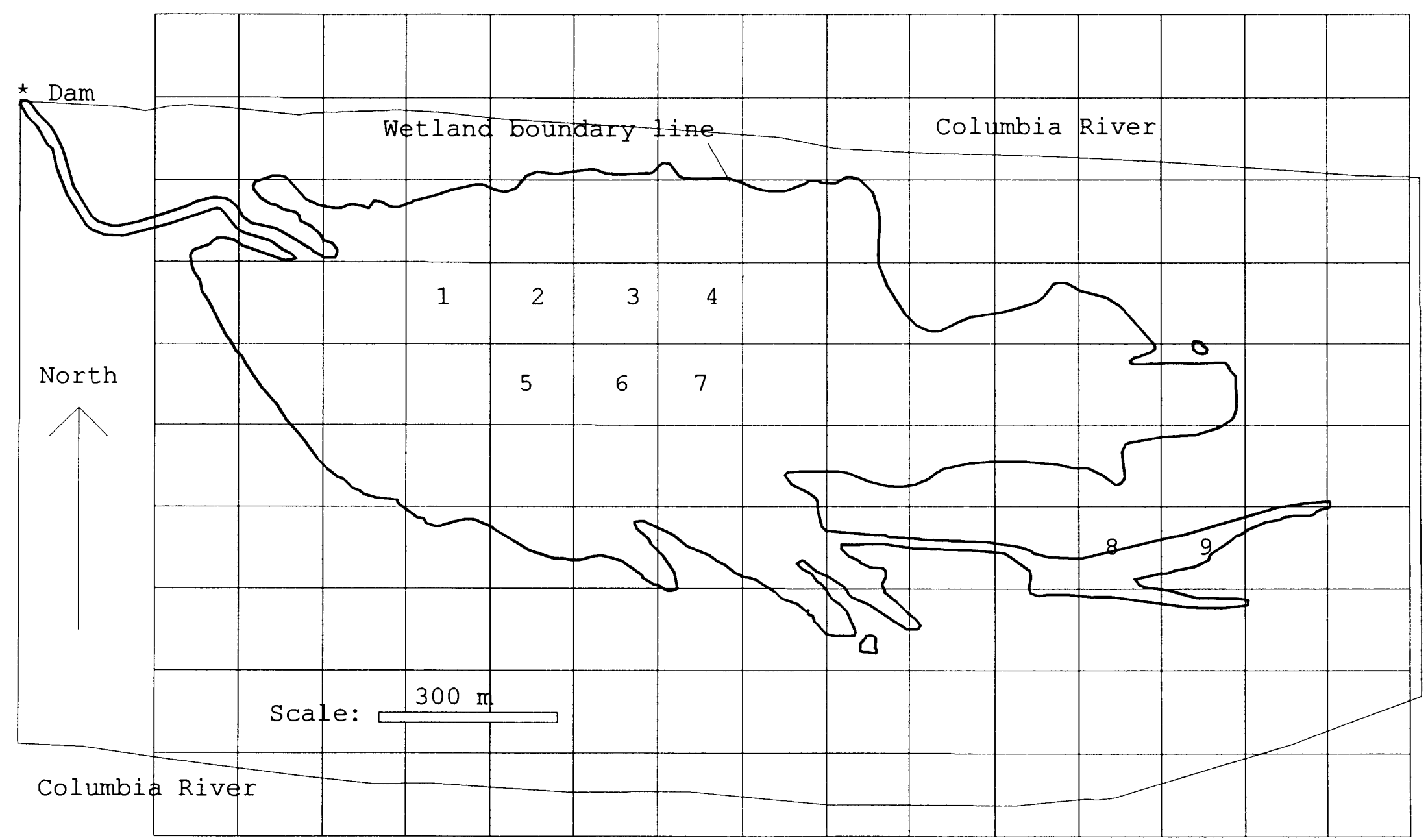

Figure 27. Locations of Jewit Lake and Southeast Pond in MODFLOW at elevations between 3.3 and $3.6 \mathrm{~m}$ (11 and $12 \mathrm{ft}$ ). Numbers represent nodes of Jewit Lake and Southeast Pond in MODFLOW between 3.3 and $3.6 \mathrm{~m}$ (11 and $12 \mathrm{ft}$ ). 
distorted in the vertical direction to account for changes in the thickness of the unit. Such distortion causes the vertical dimension to vary at each cell within a layer. Variations in the VCONT values of layer 3 control the thickness of the entire confining unit. Despite heterogeneities, the confining unit was modeled as one layer in the groundwater model because groundwater flow is expected to be vertical through the unit. Vertical groundwater flow rates are controlled by the zone of lowest hydraulic conductivity in the unit. Water cannot flow through zones of higher hydraulic conductivity in the vertical direction at any velocity different than the velocity that water flows through the lowest conductivity zone. Sand lenses interbedded within the silt and clay have little influence on the rate of water movement through the unit because the silt and clay layers surrounding the sand layers have lower hydraulic conductivities than the sands.

The top of the aquifer was assigned a uniform elevation of $1.7 \mathrm{~m}$ ( $5 \mathrm{ft}$ ) m.s.l. The approximate elevation of the top of the aquifer is known from 1 excavation in Southeast Pond, 4 excavations in Jewit Lake, and 2 monitoring points (38 and 40) that penetrate the unit (Figure 28). These observations were made on November 11th, 1993, July 8th, 1994, and August 16th, 1994 


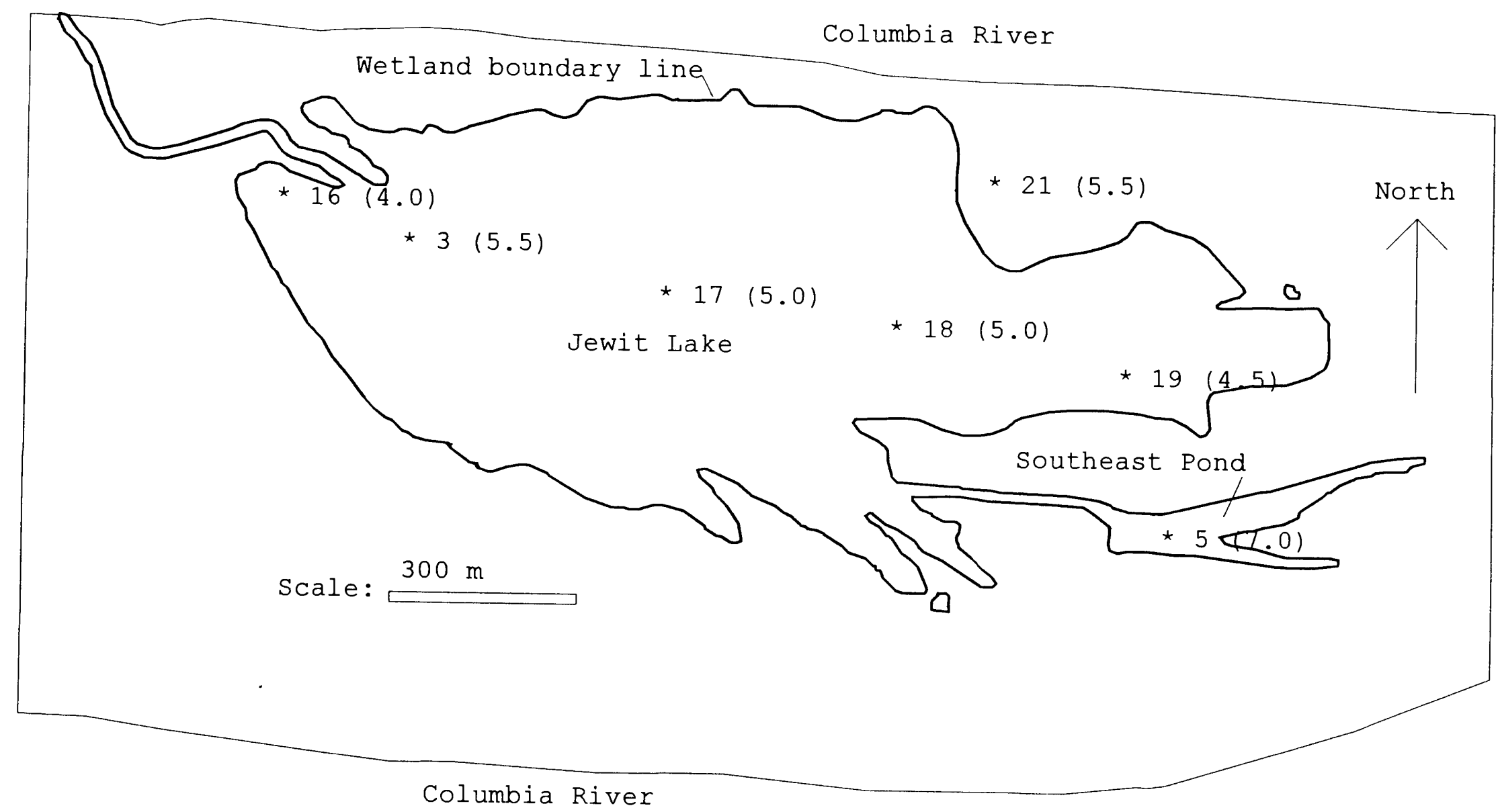

Figure 28. Locations where the aquifer was located during fieldwork. A stratigraphic column of each point is given in Appendix 4. Elevations of each point are shown in parentheses (ft, m.s.l.). 
respectively. The approximate elevations of the top of the aquifer at the points in Figure 28 are shown in Table VII. Stratigraphic columns of the points shown in Figure 28 are given in Appendix 4. Deviations from the $1.7 \mathrm{~m}$ (5 ft) m.s.l. elevation for the top of the aquifer are expected and accepted as reasonable error.

Table VII

Approximate elevations of the aquifer top at the locations shown in Figure 28.

$\frac{\text { Monitoring Point }}{6}$

3

17

18

19

21

5

Mean
Approximate Aquifer Top Elevation

\begin{tabular}{c} 
m (m.S.1.) \\
\hline 1.2 \\
1.7 \\
1.5 \\
1.5 \\
1.4 \\
1.7 \\
$\underline{2.1}$
\end{tabular}

4.0

5.5

5.0

5.0

4.5

5.5

$\frac{7.0}{5.2}$

Although the aquifer was modeled as a homogeneous, isotropic layer, it is unlikely that these conditions are present beneath the confining unit. Coarse-grained sands and gravels are likely to be interbedded with finergrained sediments. Groundwater flow is likely to occur predominantly through the zones of highest hydraulic conductivity; thus groundwater flow is not likely to be uniform throughout the unit. The aquifer was modeled as homogenous and isotropic because variability within the 
aquifer is poorly constrained. The elevation of the top of the aquifer is known only in topographically low areas. The elevation that was assigned to represent the top of the aquifer is biased since the top elevation of the aquifer is not well constrained in upland areas. It is not known whether the aquifer is continuous throughout the island.

Figures 29 and 30 are cross sections showing the stratigraphy of the mitigation site. Figure 31 shows the location of the cross sections and the sites used for construction of the cross sections. Appendix 4 contains the stratigraphic columns used in construction of the cross sections. The location of the top of the aquifer shown in Figures 29 and 30 has been inferred in the areas where it was not located. Stratigraphic columns for points that were not used for these cross sections and a map showing the location of these points are given in Appendix 4. Elevations were taken from a $0.61-m$ (2-ft) contour interval map of the study area (SRI, 1991b).

\section{Evapotranspiration in the groundwater model}

Evapotranspiration was entered into MODFLOW using data collected from the Vancouver weather station. MODFLOW uses an evapotranspiration rate versus depth function (Figure 32) to determine evapotranspiration from 


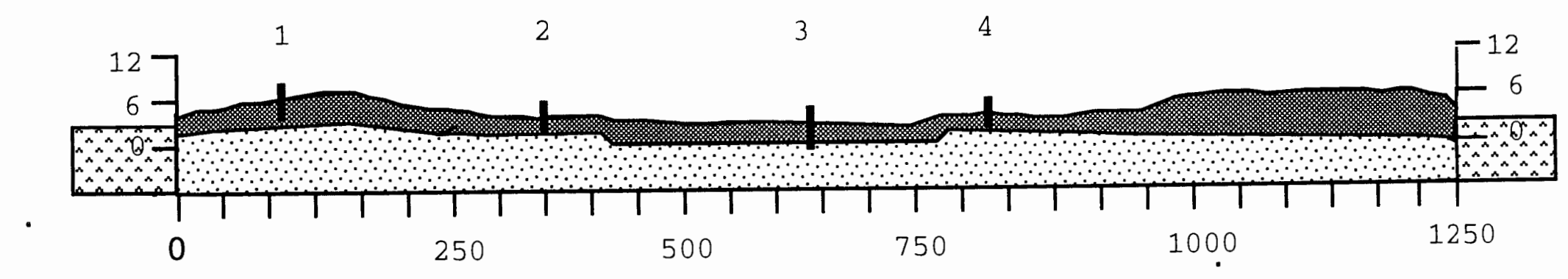

Figure 29. Cross section $A-A^{\prime}$. The location of cross section $A-A$ is $g$ iven in Figure 31. Distances are in meters. Vertical exageration $=7$. 


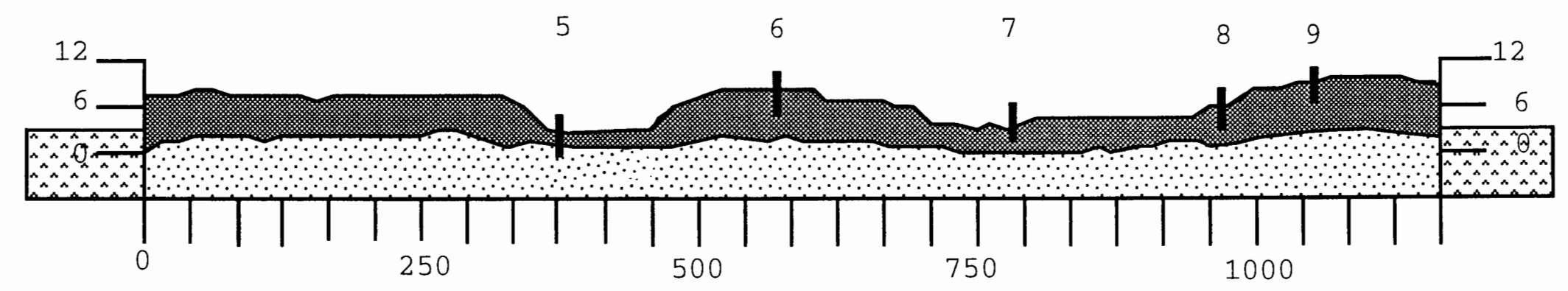

Figure 30. Cross section B-B'. The location of cross section $B-B^{\prime}$ is given in Figure 31. Distances are in meters. Vertical exageration $=7$. 


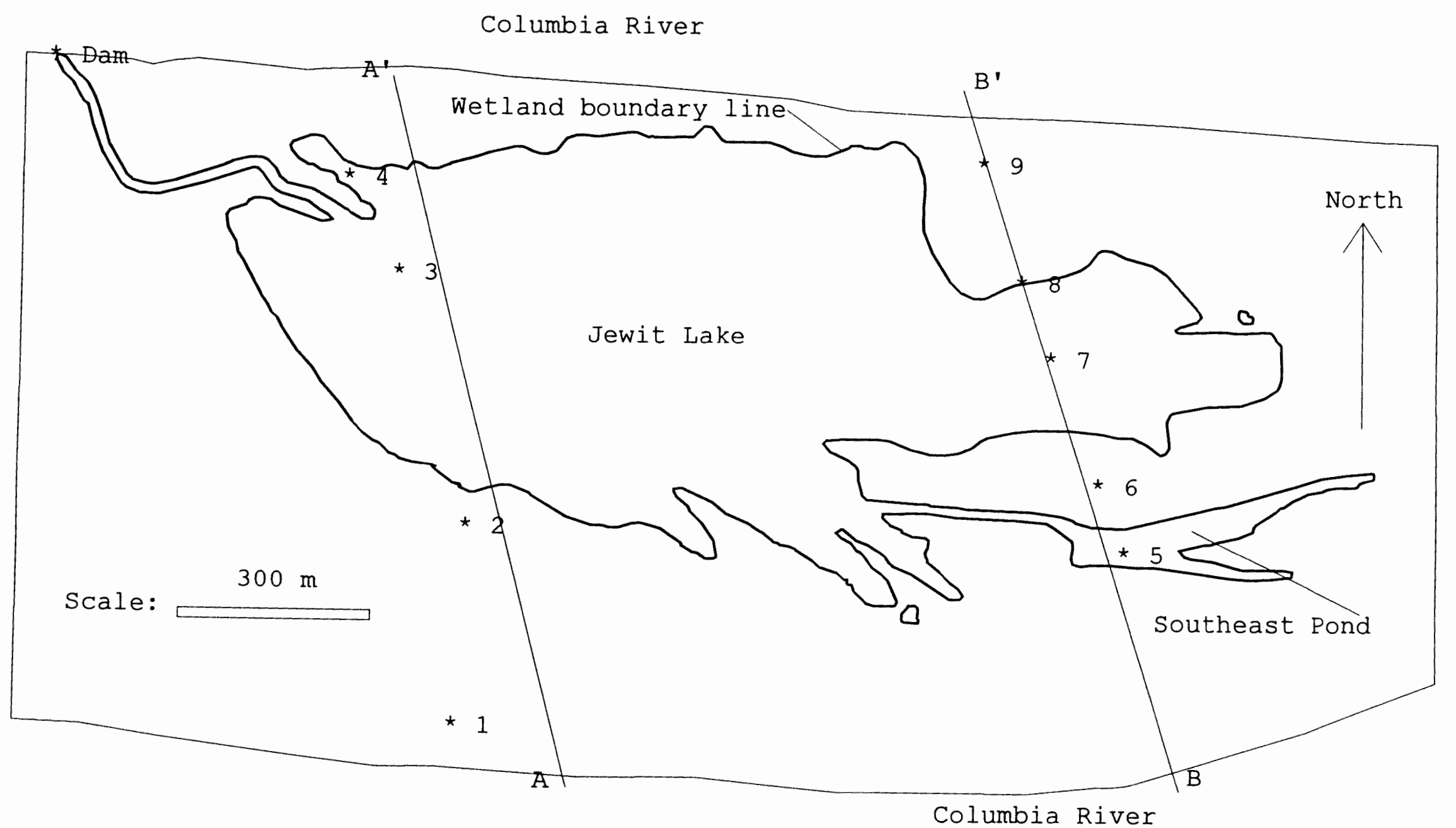

Figure 31. Site locations used for cross section construction. 
a node. Figure 32 shows that maximum evapotranspiration decreases with depth from a specified surface elevation in MODFLOW. The approximate elevation of the ground surface was entered as the elevation from which maximum evapotranspiration occurs in the groundwater model. Evapotranspiration from surface water occurs at the maximum evapotranspiration rate because surface water is located above the elevation of the ground surface. An extinction depth of $1.7 \mathrm{~m}$ (5 ft) was used because plant roots were observed extending from the ground surface to this depth.

\section{Calibration of the groundwater model}

The groundwater model was calibrated using water levels (Table II) collected at monitoring points in February, March, and April of 1994. Water levels given in Table II were compared to water levels in the groundwater model at the appropriate nodes to ensure that water levels in the groundwater model were similar to actual water levels. Precipitation and evapotranspiration were entered into MODFLOW using actual data collected from the National Weather Service and the Vancouver weather station for February, March and April of 1994. Table VIII shows actual water levels collected in February, March, and April of 1994 and water levels obtained in the groundwater 


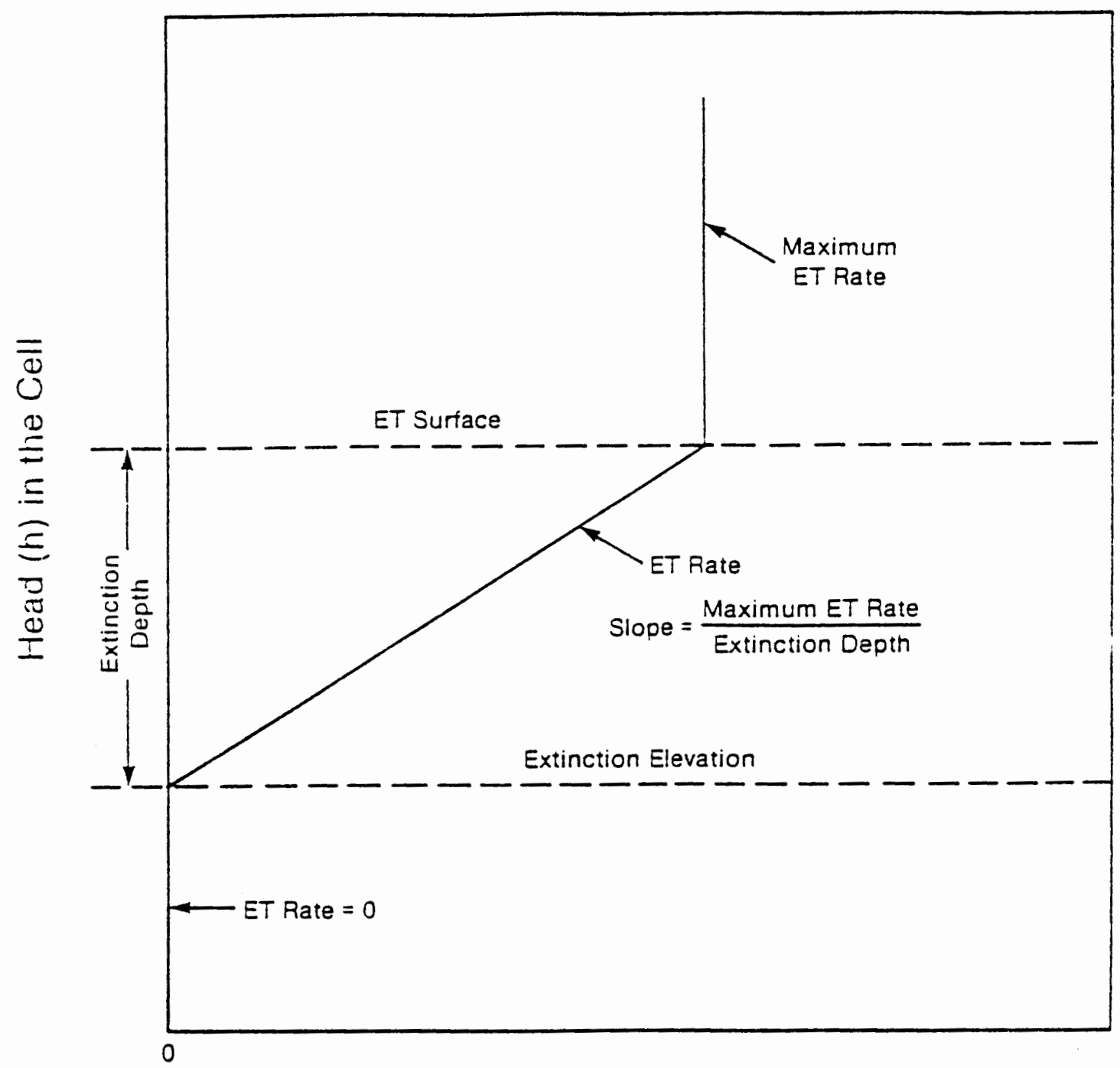

Evapotranspiration ( $E T$ )

Figure 32. Evapotranspiration as a function of head (MCDonald and Harbaugh, 1984). 
Table VIII

Actual and modeled water levels on Government Island for February, March, and April, 1994.

\begin{tabular}{|c|c|c|c|c|c|c|c|c|c|c|}
\hline \multicolumn{4}{|c|}{ Field data (also given in Table II) } & & & \multirow{2}{*}{\multicolumn{4}{|c|}{$\begin{array}{l}\text { Modeling results in the node } \\
\text { containing the monitoring point }\end{array}$}} & \\
\hline & & & & & & & & & & \\
\hline monitoring point & $2 / 6 / 94$ & $3 / 6 / 94$ & $4 / 2 / 94$ & $4 / 3 / 94$ & $4 / 10 / 94$ & Feb-94 & Mar-94 & Apr-94 & & \\
\hline \#11 & dry & 11.05 & 10.46 & 10.4 & 10.99 & 10.98 & 11.4 & 11.92 & & \\
\hline$\# 12$ & $\mathrm{n} / \mathrm{a}$ & $\mathrm{n} / \mathrm{a}$ & 10.74 & 10.6 & 11.23 & 10.98 & 11.4 & 11.92 & & \\
\hline$\# 13$ & 10.82 & 11.93 & 10.76 & 10.66 & 11.37 & 11.04 & 11.4 & 11.97 & & \\
\hline$\# 20$ & dry & 11.86 & dry & dry & dry & 11.28 & 11.32 & 11.75 & & \\
\hline$\# 23$ & 14.26 & 15.35 & 15.18 & 15.16 & 15.59 & 12.25 & 11.3 & 11.37 & & \\
\hline$\# 25$ & dry & 16.51 & 16.29 & 16.26 & 16.97 & 12.25 & 11.3 & 11.37 & & \\
\hline$\# 26$ & 15.54 & 17.48 & 16.54 & 16.5 & 17.42 & 12.25 & 11.3 & 11.37 & & \\
\hline$\# 30$ & $\mathrm{n} / \mathrm{a}$ & $\mathrm{n} / \mathrm{a}$ & $\mathrm{n} / \mathrm{a}$ & $\mathrm{n} / \mathrm{a}$ & $?$ & 11.7 & 10.86 & 11.06 & & \\
\hline$\# 31$ & $\mathrm{n} / \mathrm{a}$ & $n / a$ & $\mathrm{n} / \mathrm{a}$ & $n / a$ & 12.03 & 11.09 & 11.26 & 11.6 & & \\
\hline$\# 32$ & $\mathrm{n} / \mathrm{a}$ & $\mathrm{n} / \mathrm{a}$ & $\mathrm{n} / \mathrm{a}$ & $n / a$ & 11.09 & 10.91 & 11.15 & 11.46 & & \\
\hline$\# 33$ & $n / a$ & $\mathrm{n} / \mathrm{a}$ & $\mathrm{n} / \mathrm{a}$ & $\mathrm{n} / \mathrm{a}$ & 11.35 & 10.99 & 11.14 & 11.39 & & \\
\hline Jewit Lake & dry & 11.21 & 11.67 & 11.62 & 11.66 & 11.3 & 11.71 & 11.58 & & \\
\hline staff gauge & & & & & & & & & & \\
\hline Southeast Pond & $\mathrm{n} / \mathrm{a}$ & 13.1 & 12.67 & 12.6 & 12.85 & 11.65 & 13.4 & 12.94 & & \\
\hline staff gauge & & & & & & & & & & \\
\hline
\end{tabular}


model node where the appropriate water level was observed. Table VII shows that water levels obtained in the groundwater model are mostly within $20 \mathrm{~cm}$ ( 8 in) of water levels observed at monitoring points. Water levels observed at monitoring points 23,25 , and 26 ( 1 node) were consistently 1 to $1.3 \mathrm{~m}$ (3 to $4 \mathrm{ft}$ ) higher than water levels obtained in groundwater modeling. Hydraulic conductivities in the node containing monitoring points 23,25 , and 26 were not altered so that modeling results would match actual water levels. Changes to the hydraulic conductivity and VCONT values in the node containing monitoring points 23,25 , and 26 caused unreasonable water levels to be present when the groundwater model was run from June through December.

Water levels from May 1994 to December 1994 were not used to calibrate the groundwater model because observations of the water table could not be made at many of the monitoring points. Water table levels fell below observable depths at many of the monitoring points. Jewit Lake water levels were not modeled from May 1994 through December 1994 because running the groundwater model with beginning lake levels of $3.5 \mathrm{~m}$ ( $11.5 \mathrm{ft}$ ) would cause the nodes in layer 1 to go to no-flow (inactive).

Precipitation cannot enter the model and evapotranspiration cannot leave the model if the nodes in 
layer 1 go to no-flow. Water levels in the groundwater model would be inaccurate if the groundwater model was run using actual data from June of 1994. In 1994, Jewit Lake had a level of $3.5 \mathrm{~m}(11.5 \mathrm{ft})$ at the end of May. The Columbia River in 1994 (Figure 11) maintained levels in January through september that were lower than any year between 1973 and 1989. Precipitation in January through September was below average and evapotranspiration rates were above average. Water levels from May 1994 through December 1994 were chosen to represent the minimum amount of water that will be present May through December in any year at Government Island.

Inspection of hydrographs between 1973 and 1989 (Appendix 1, Figure 12) indicate that peak flows of the Columbia River at Government Island usually occur in December through January and May through June. One aspect of groundwater modeling of the study area focused on flooding of the island during peak flow events and the levels of water retained after flooding as a function of time. A river elevation greater than $3.6 \mathrm{~m}(12.0 \mathrm{ft})$ m.s.l. is required to flood Jewit Lake through the dam (Figure 8) and the spillway channel. This is known from an observation of the Jewit Lake level at the staff gauge on January 22, 1995. On January 22, 1995, Jewit Lake was filling and draining as the level of the Columbia River 
fluctuated throughout the day. A maximum water level of $4.7 \mathrm{~m}$ ( 15.3 ft) m.s.I. can be retained in Jewit Lake by the dam once the Columbia River receeds following a highflow event.

\section{RESULTS OF GROUNDWATER MODELING}

\section{Climate as a variable in groundwater modeling}

The MODFLOW program was used to model lake levels for the months of June through December. The model was run by entering the beginning lake levels, Columbia River level, precipitation, and evapotranspiration. Changes in lake levels were observed at 30 day intervals. Figures 33, 34, and 35 show precipitation, evapotranspiration, and groundwater infiltration from June through December with average precipitation and evapotranspiration; 50 percent above average precipitation and 25 percent below average evapotranspiration; and 50 percent below average precipitation and 25 percent above average evapotranspiration, respectively. Figures 18 and 19 show that 1993 and 1994 monthly precipitation rates are usually within 50 percent of the National weather service monthly average precipitation. Figure 20 shows that 1993 and 1994 monthly evapotranspiration rates are usually within 25 percent of the monthly average evapotranspiration at the 


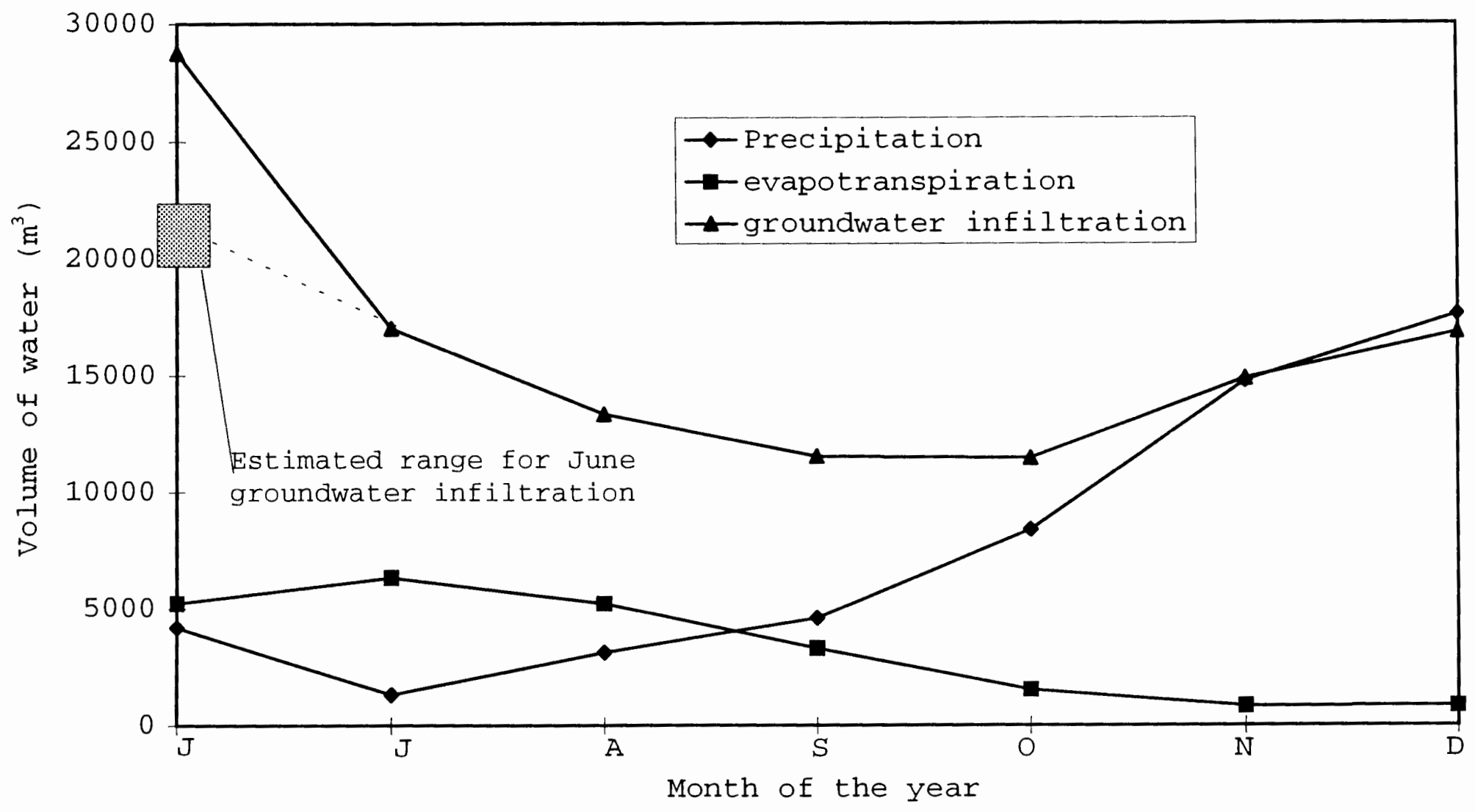

Figure 33. Precipitation, evapotranspiration, and groundwater infiltration from June through December with average precipitation and evapotranspiration rates. 


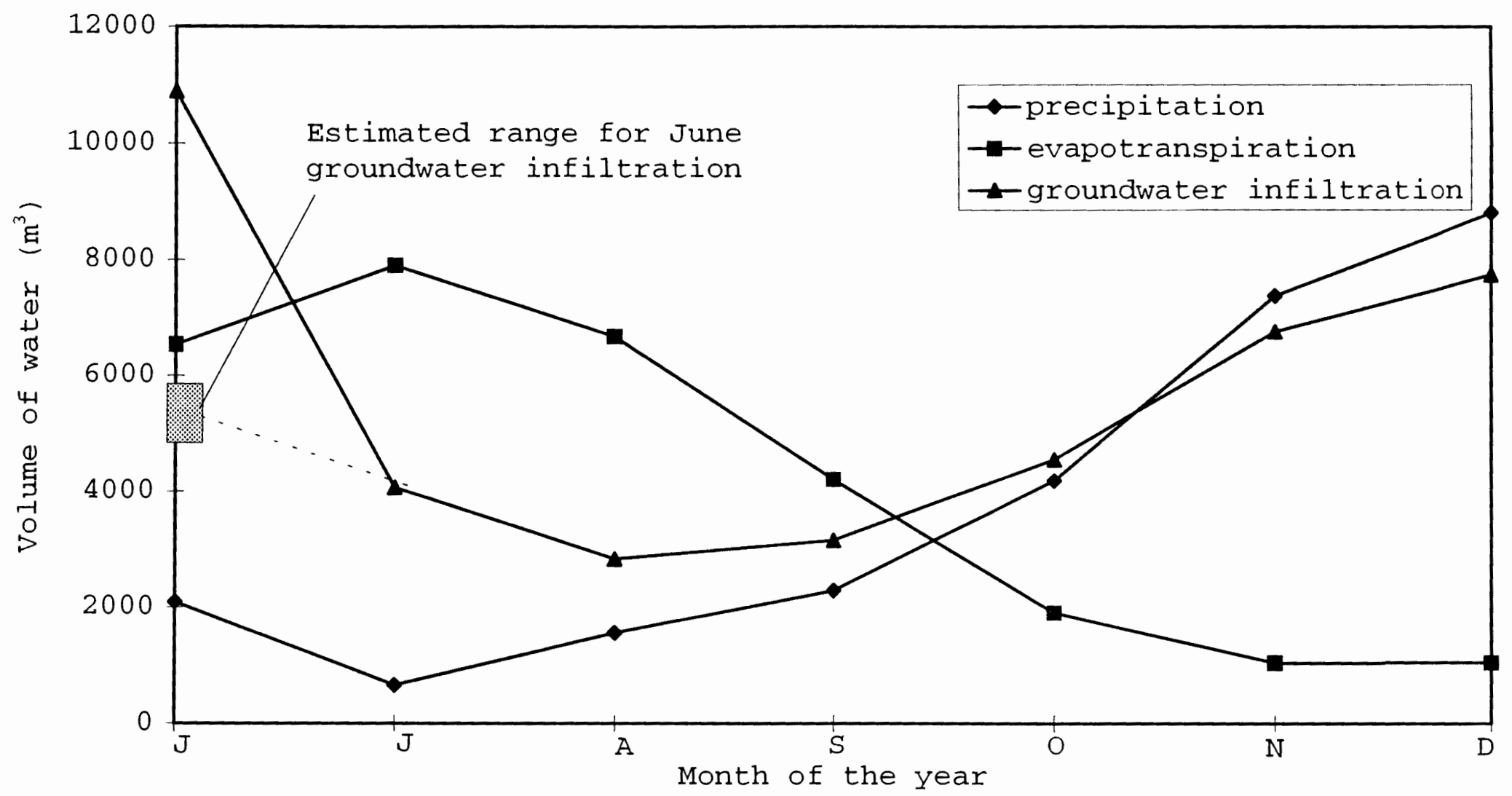

Figure 34. Precipitation, evapotranspiration, and groundwater infiltration from June through December with above average precipitation and below average evapotranspiration rates. 


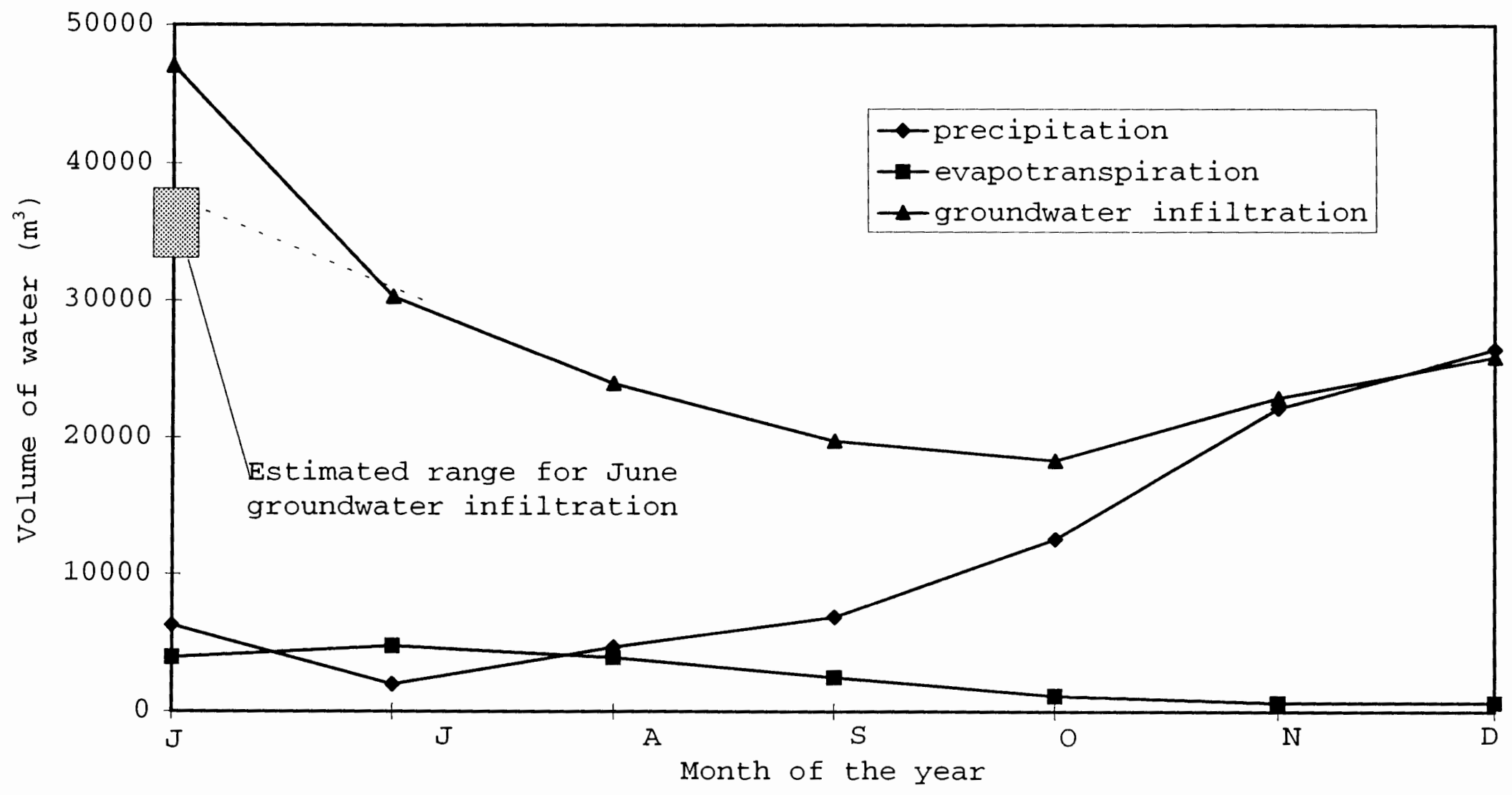

Figure 35. Precipitation, evapotranspiration, and groundwater infiltration from June through December with below average precipitation and above average evapotranspiration rates. 
Vancouver weather station. Figures 33, 34, and 35 show that the amount of groundwater infiltration is dependent upon rates of precipitation and evapotranspiration. The groundwater infiltration curves are inaccurate for the month of June because water flows into storage during the first iteration of each modeling simulation to achieve an equilibrium condition in the model. Figures 33, 34, and 35 show approximations of groundwater infiltration for the month of June. June groundwater infiltration is approximated by extrapolating the slope of the line representing groundwater infiltration for July and August to the $y$-axis. The shaded rectangle in Figures 33, 34, and 35 represents an estimation of the range for June groundwater infiltration.

Groundwater modeling of the site is used to determine the length of time that water will be absent from Jewit Lake and Southeast Pond when lake levels of $4.0,4.3$ and $4.6 \mathrm{~m}$ (13, 14 and $15 \mathrm{ft})$ occur following late May/early June flooding of the study area (Table IX). Table IX shows periods of drying in Jewit Lake and Southeast Pond based on modeling. Columbia River levels are maintained at a level of approximately $2.9 \mathrm{~m}$ (9.5 ft) m.s.l. during the summer months in most years (Appendix 1). Thus the groundwater model is set up to examine the time for Jewit Lake and Southeast Pond to dry keeping the Columbia River 
Table IX

Simulation identifying months where water is absent in Jewit Lake and Southeast Pond for years when flooding occurs through the spillway channel.

MAY 31 LAKE LEVEL PRECIPITATION JEWIT LAKE SE POND

$\begin{array}{llll}4.0 \mathrm{~m} & \text { AVERAGE } & \text { AUG. -DEC. } & \text { AUG. OCT. } 15 \\ 4.0 \mathrm{~m} & \text { ABOVE AVERAGE } & \begin{array}{l}\text { AUG. 15- } \\ \text { NOV. 15 }\end{array} & \begin{array}{l}\text { AUG. 15- } \\ \text { SEPT. }\end{array} \\ 4.0 \mathrm{~m} & \text { DOUBLE } & \begin{array}{l}\text { SEPT. } \\ \text { OCT. } 15\end{array} & \text { NONE } \\ 4.3 \mathrm{~m} & \text { NONE } & \text { OCT. - } & \text { SEPT. - } \\ 4.3 \mathrm{~m} & \text { AVERAGE } & \text { OCT. } & \text { OCT. } \\ 4.3 \mathrm{~m} & \text { ABOVE AVERAGE } & \text { NONE } & \text { NONE } \\ 4.6 \mathrm{~m} & \text { NONE } & \text { OCT. - } & \text { SEPT. - } \\ 4.6 \mathrm{~m} & \text { BELOW AVERAGE } & \text { OCT. - } & \text { OCT. 15- } \\ & & \text { NOV 30 } & \text { NOV. 15 } \\ 4.6 \mathrm{~m} & \text { AVERAGE } & \text { NONE } & \text { NONE }\end{array}$

level at $2.9 \mathrm{~m}$ (9.5 ft) m.s.l. Precipitation rates, evapotranspiration rates, and beginning lake levels were used as variables in the MODFLOW program based on actual data given in Figures 18, 19, and 20 and Table II.

Predictions of the times of the year that water will be absent from Jewit Lake and Southeast Pond are shown in Table IX and Figures 36 and 37. In Table IX, simulations that receive no precipitation indicate an indefinite ending time for the drying period. This occurs because 


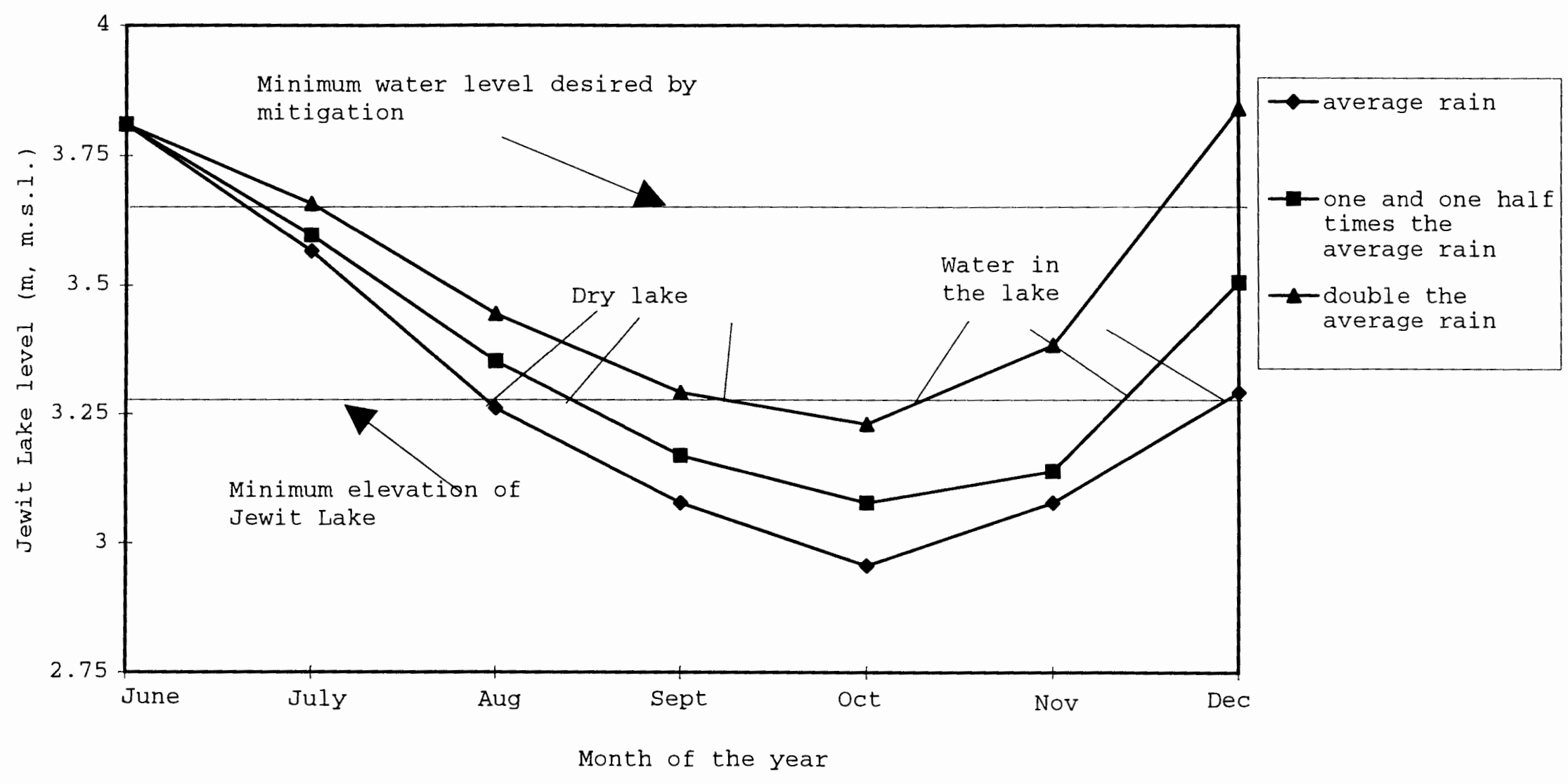

Figure 36. Water levels in Jewit Lake from June through December with variable rates of precipitation in years when no flooding occurs through the spillway channel. 

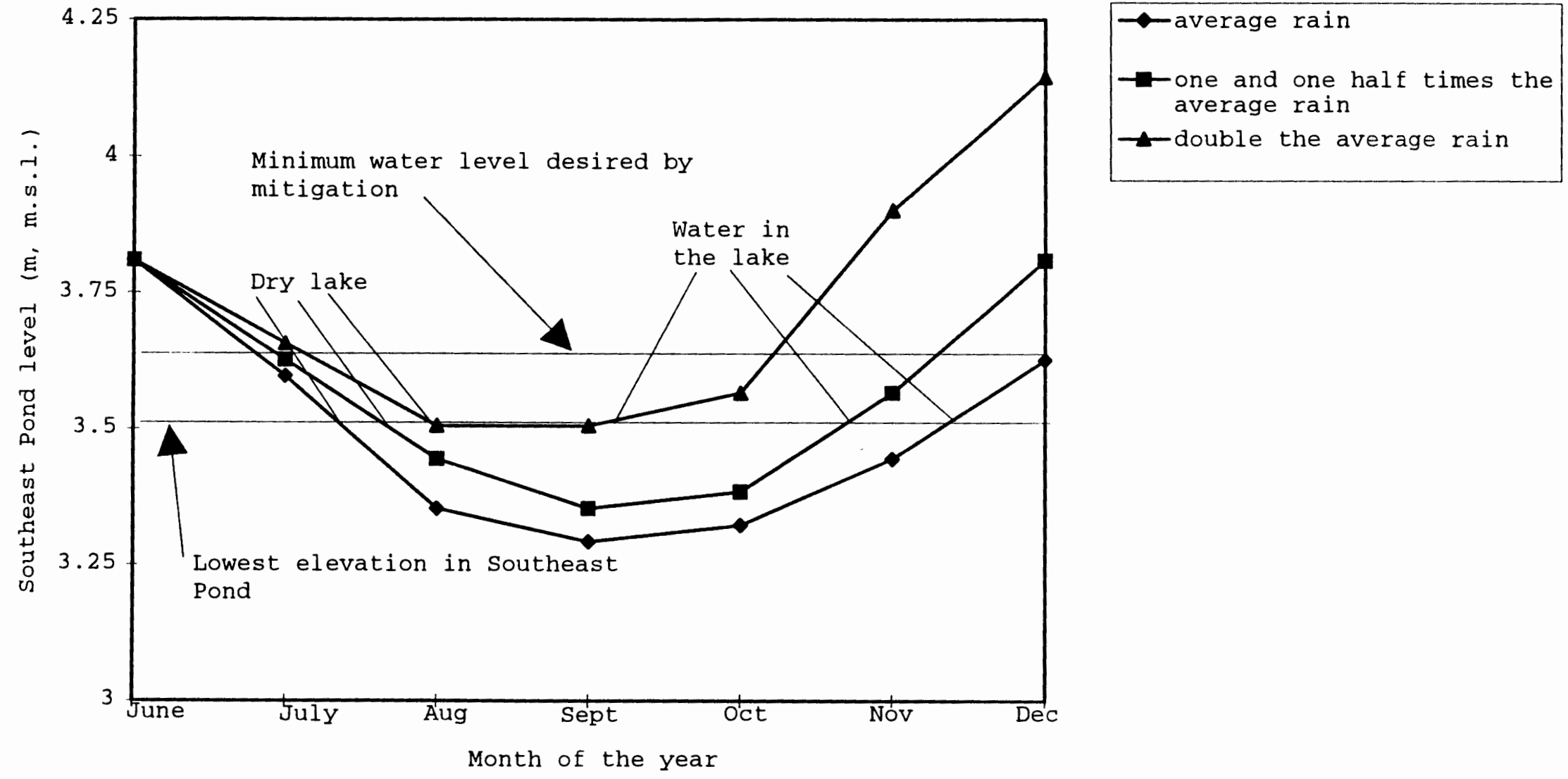

Figure 37. Water levels in Southeast Pond from June through December with variable rates of precipitation in years when no water flows overland from Jewit Lake to Southeast Pond. 
Columbia River levels are lower than the lowest point in Jewit Lake and Southeast Pond. Jewit Lake and Southeast Pond decrease in water level without receiving water from precipitation or the Columbia River.

The Columbia River may not reach an elevation above $3.8 \mathrm{~m}(12.5 \mathrm{ft}) \mathrm{m} . \mathrm{s} .1$. in the months of May or June. If this is the case, then Jewit Lake will not be flooded through the spillway channel. A beginning lake level of $3.8 \mathrm{~m}$ (12.5 ft) m.s.l. was modeled receiving average, above average, and twice the average precipitation in the months of June through December. A lake level of $3.8 \mathrm{~m}$ (12.5 ft) was chosen because Jewit Lake reached a level of $3.8 \mathrm{~m}$ (12.5 ft) in 1994 (Table II) though no flooding through the spring loaded gates occurred. The purpose of modeling lake levels that have not received water through the spillway channel was to determine the length of time that rainfall alone could prevent Jewit Lake or southeast Pond from drying. Results indicate that drying will occur in both lakes in years when flooding through the spillway channel does not occur (Figures 36 and 37). Higher rates of precipitation decrease the amount of time that dry conditions are present in the lakes.

Water leaves the groundwater model by infiltration into the aquifer which flows to the Columbia River and by evapotranspiration. Evapotranspiration rates were altered 
depending upon the amount of rainfall being modeled. Above average and below average evapotranspiration rates were estimated to be 25 percent above and below, respectively, average evapotranspiration rates in Vancouver, Washington. When above average rainfall for a month was being simulated, below average evapotranspiration rates were used. When below average or no rainfall conditions were being simulated, above average evapotranspiration rates were used. Figure 38 shows the monthly evapotranspiration used in groundwater modeling. Figure 20 indicates that the summer of 1993 had below average evapotranspiration and the summer of 1994 had above average evapotranspiration. Comparison of Figure 20 with Figure 38 indicates that the 25 percent variation from average evapotranspiration is a reasonable approximation of the variability in evapotranspiration that is expected to occur at Government Island.

\section{Hydraulic conductivity of the confining unit as a variable in groundwater modeling}

Samples analyzed for particle size distribution indicate that the confining unit is predominately silt, with clay, fine sand, colloids, and organic matter (Table V). Sample 15 was collected from a disturbed area behind the dam (Figure 22) and is not indicative of the composition of the confining unit. The confining unit was 


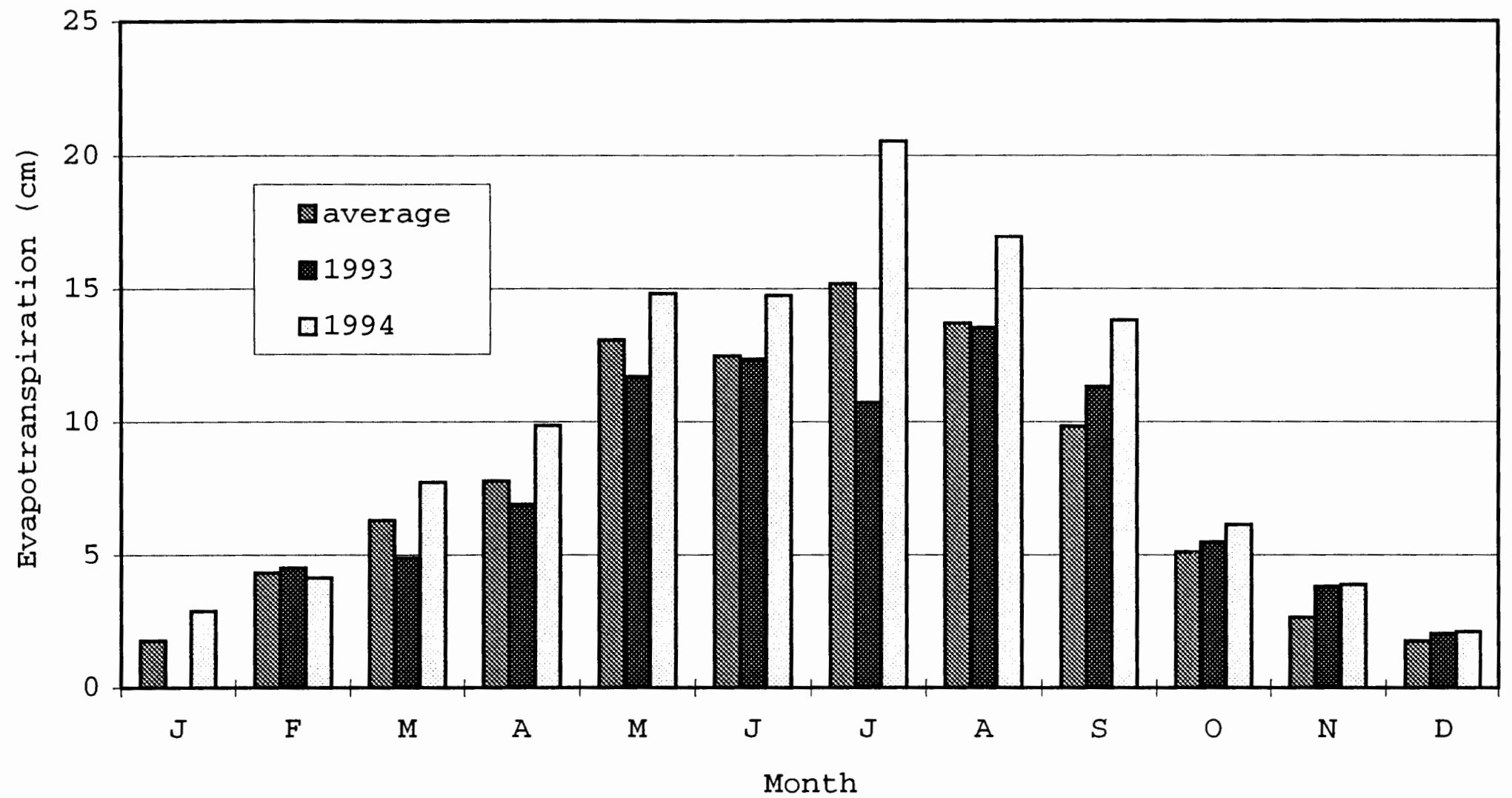

Figure 38. Monthly evapotranspiration entered into MODFLOW. 
modeled using a hydraulic conductivity of $15.2 \mathrm{~cm} /$ day $(0.5$ ft/day) for all of the nodes except 3. The conductivity of the confining unit at southeast Pond ( 2 nodes) was approximated at $6.1 \mathrm{~cm} /$ day $(0.2 \mathrm{ft} /$ day $)$. Sediments underlying Southeast Pond ( 2 nodes) contain 4 percent more clay than any other sample analyzed from the confining unit (Table V). Variations in the hydraulic conductivity of the confining unit outside of southeast Pond was not attempted as samples may not represent the lowest conductivity zone in the layer at the sampling site. A sand and gravel layer of unknown lateral extent located approximately $40 \mathrm{~m}$ ( $131 \mathrm{ft}$ ) west of Southeast Pond was assigned one node in the MODFLOW grid. The sand and gravel layer was assigned one node because no other sand and gravel layers were located in vicinity of southeast Pond. A conductivity value of $30.5 \mathrm{~m} /$ day $(100 \mathrm{ft} /$ day) was assigned to the sand and gravel layer based on the values of hydraulic conductivity given for gravels in (Freeze and Cherry, 1979).

The hydraulic conductivity of the confining unit was estimated at $15.2 \mathrm{~cm} /$ day $(0.5 \mathrm{ft} /$ day $)$ because Southeast Pond maintained surface water in October of 1993 (Table I) when Jewit Lake was dry; thus the confining unit at Southeast Pond has a lower hydraulic conductivity than the remainder of the confining unit. A hydraulic conductivity 
of $15.2 \mathrm{~cm} /$ day $(0.5 \mathrm{ft} /$ day) is in the upper-value range of hydraulic conductivities given for silts in Freeze and Cherry (1979).

Figure 39 shows modeling results of Southeast Pond levels from June 1, 1994 through September 1, 1994 using hydraulic conductivity values of $6 \mathrm{~cm} /$ day $(0.2 \mathrm{ft} /$ day), $2.7 \mathrm{~cm} /$ day $(0.09 \mathrm{ft} /$ day $)$ and $0.4 \mathrm{~cm} /$ day $(0.013 \mathrm{ft} /$ day $)$. Figure 39 is used to validate the hydraulic conductivity value of $0.2 \mathrm{ft} /$ day used in modeling for the 2 nodes representing Southeast Pond. Lake levels are highest as hydraulic conductivity values are decreased (Figure 39).

In order to assess the effect of the hydraulic conductivity of the confining unit on lake levels, values of $2.7 \mathrm{~cm} /$ day $(0.09 \mathrm{ft} /$ day $)$ and $0.4 \mathrm{~cm} /$ day $(0.013 \mathrm{ft} /$ day $)$ were used in the groundwater model for the hydraulic conductivity of the confining unit. These values are in the middle and lower value range, respectively, of hydraulic conductivities for silts (Freeze and Cherry, 1979). Average precipitation and evapotranspiration are held constant as hydraulic conductivity values are altered. Figure 40 shows Jewit Lake levels based on modeling from the end of June through November. Figure 40 shows that lake levels are highest when the hydraulic conductivity of the confining unit is decreased. 


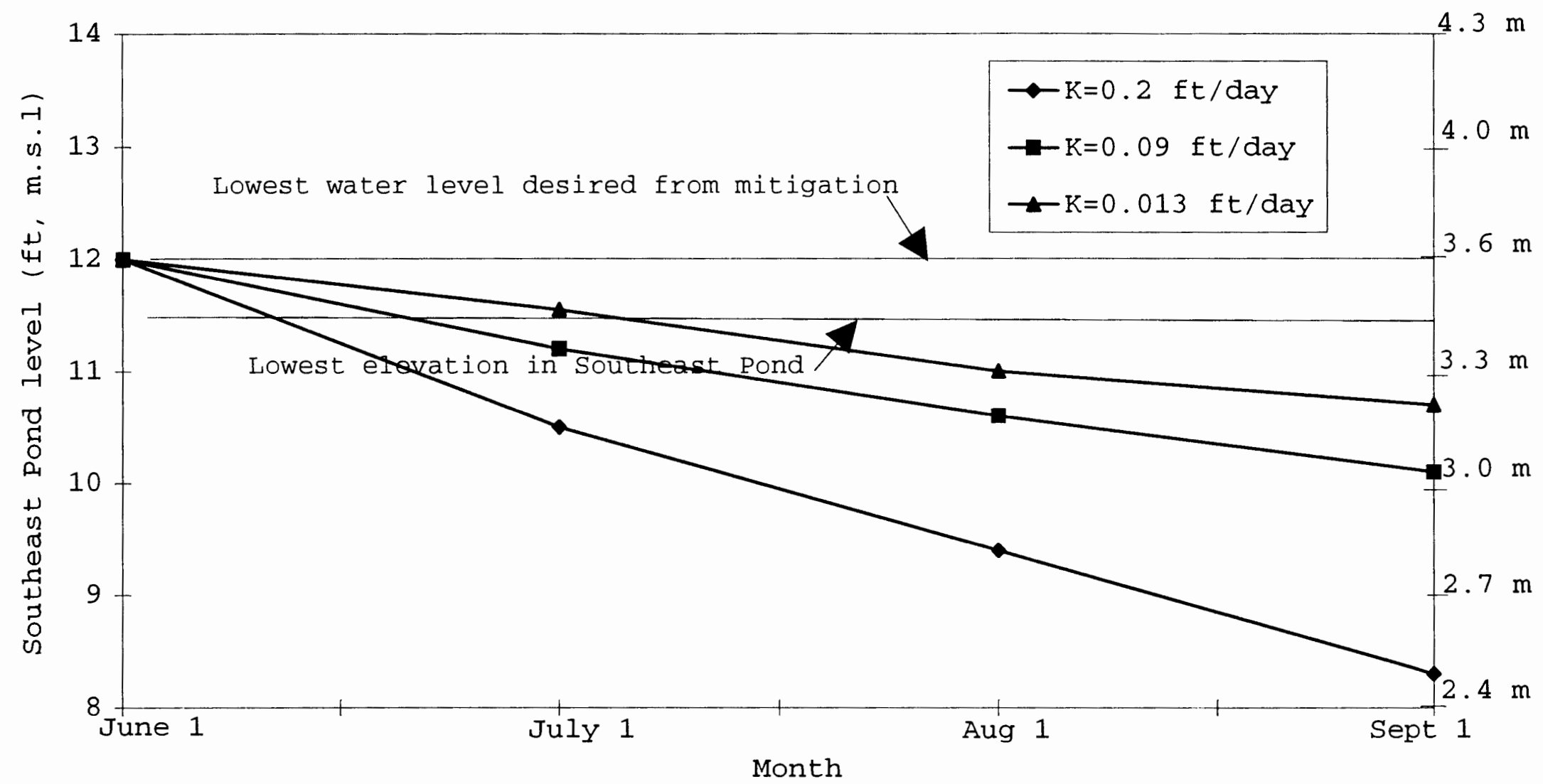

Figure 39. Variations in Southeast Pond water levels from June 1,1994 to September 1, 1994 using hydraulic conductivity values given for silts (Freeze and Cherry, 1979). 


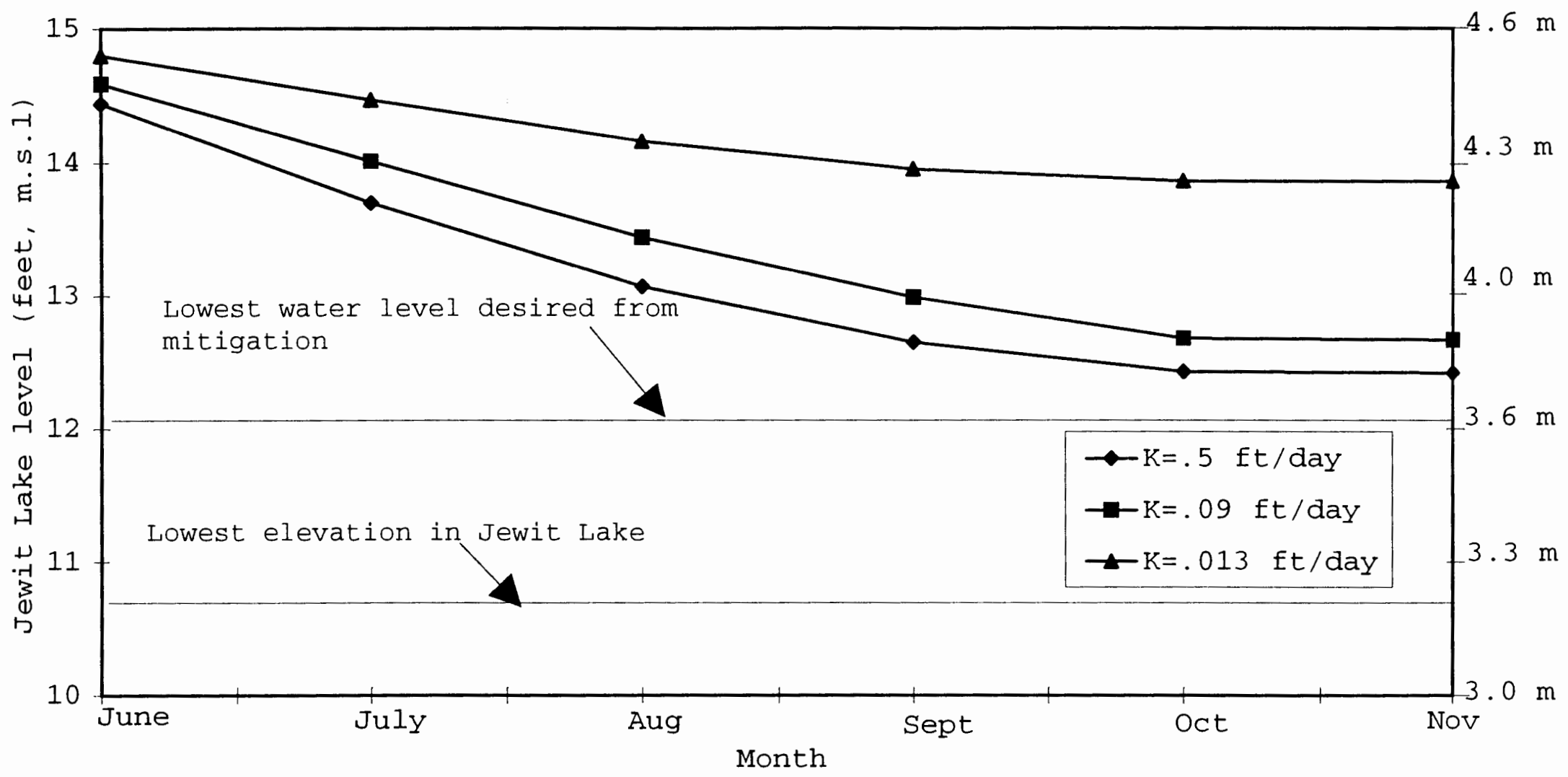

Figure 40. Variations in Jewit Lake water levels from June through November using hydraulic conductivity values given for silts (Ereeze and Cherry, 1979). 


\section{Aquifer transmissivity as a variable in groundwater} modeling

The effect of aquifer transmissivity on lake levels was modeled by using values of $259 \mathrm{~m} /$ day, $2590 \mathrm{~m} /$ day, and $25900 \mathrm{~m} /$ day $(850 \mathrm{ft} /$ day, $8500 \mathrm{ft} /$ day, and $85000 \mathrm{ft} /$ day $)$ for aquifer transmissivity. These values were derived from the lower, middle, and upper range of values, respectively, of the hydraulic conductivity for sands (Freeze and Cherry, 1979). A hydraulic conductivity of $0.5 \mathrm{ft} /$ day was used for the confining unit as the values of transmissivity were changed. Figures 41 and 42 show water levels in Jewit Lake and Southeast Pond from June through December using transmissivity values of $259 \mathrm{~m} /$ day, $2590 \mathrm{~m} /$ day, and $25900 \mathrm{~m} /$ day $(850 \mathrm{ft} /$ day, $8500 \mathrm{ft} /$ day, and $85000 \mathrm{ft} /$ day). Lake levels are highest when the values of transmissivity are lowest (Figures 41 and 42 ). Site monitoring in 1993 through 1995 indicates that water levels in Jewit Lake and Southeast Pond are most likely to approach water levels obtained using a transmissivity value of $2590 \mathrm{~m} /$ day (8500 ft/day).

\section{Predictions of the site conditions based on modeling results}

Figures 43 and 44 show the levels of Jewit Lake and Southeast Pond from May 31 to December 31 based on modeling. A hydraulic conductivity of $15.2 \mathrm{~cm} /$ day 10.5 ft/day) and a transmissivity value of $2590 \mathrm{~m} /$ day $(8500$ 


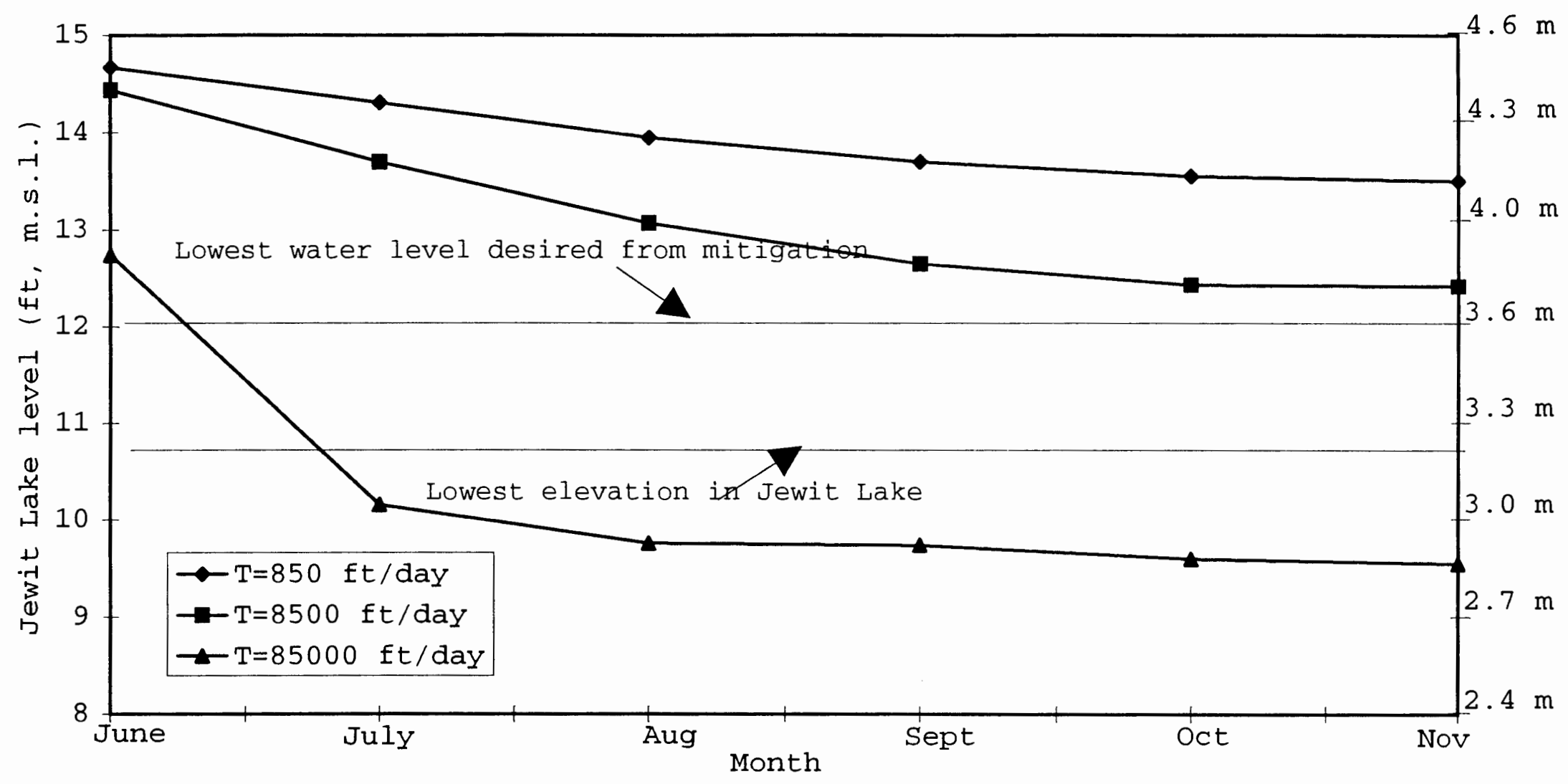

Figure 41. Variations in Jewit Lake water levels from June through November using transmissivity values given for sands (Freeze and Cherry, 1979). 


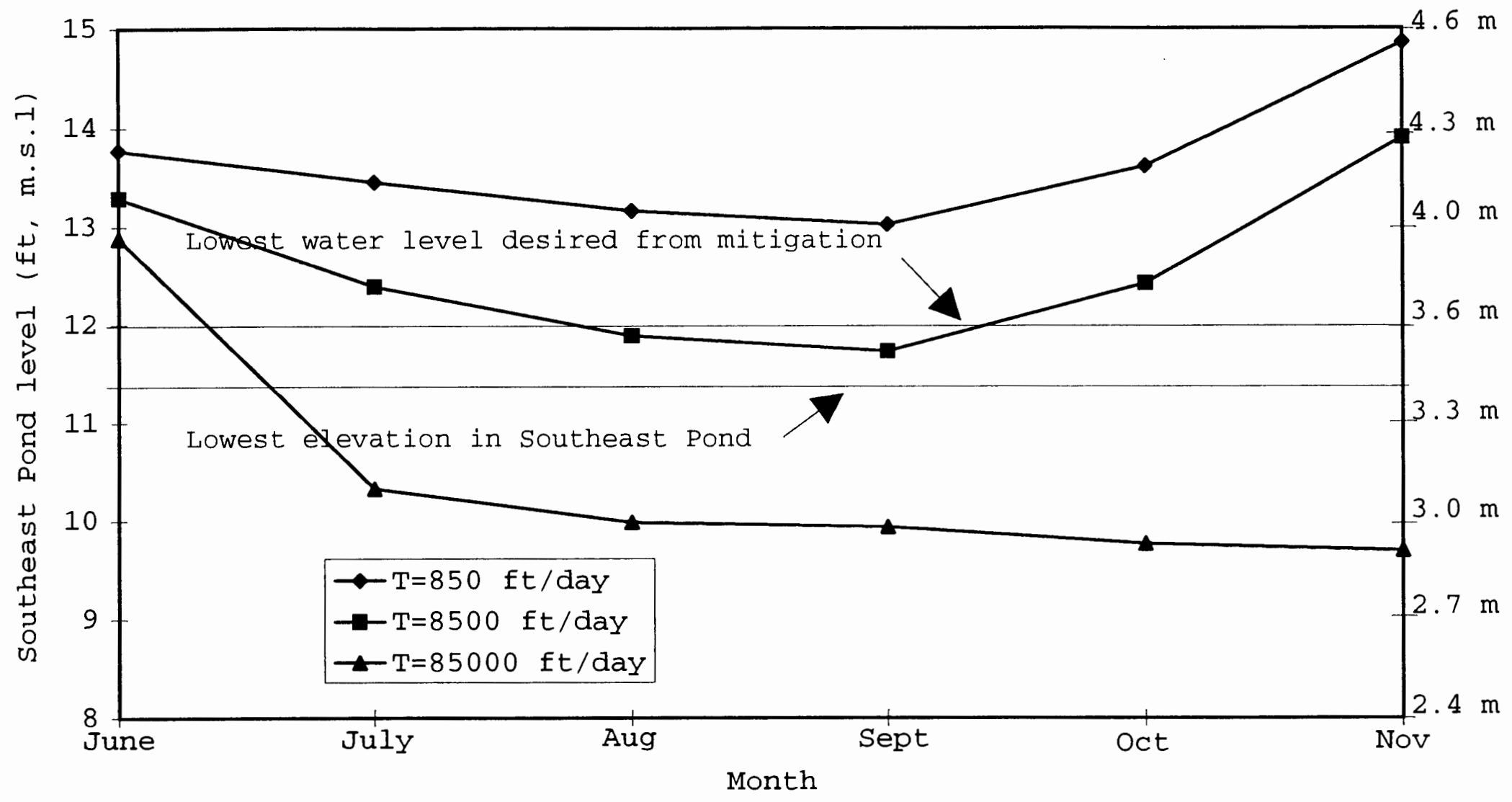

Figure 42. Variations in Southeast Pond water levels from June through November using transmissivity values given for sands (Freeze and Cherry, 1979). 


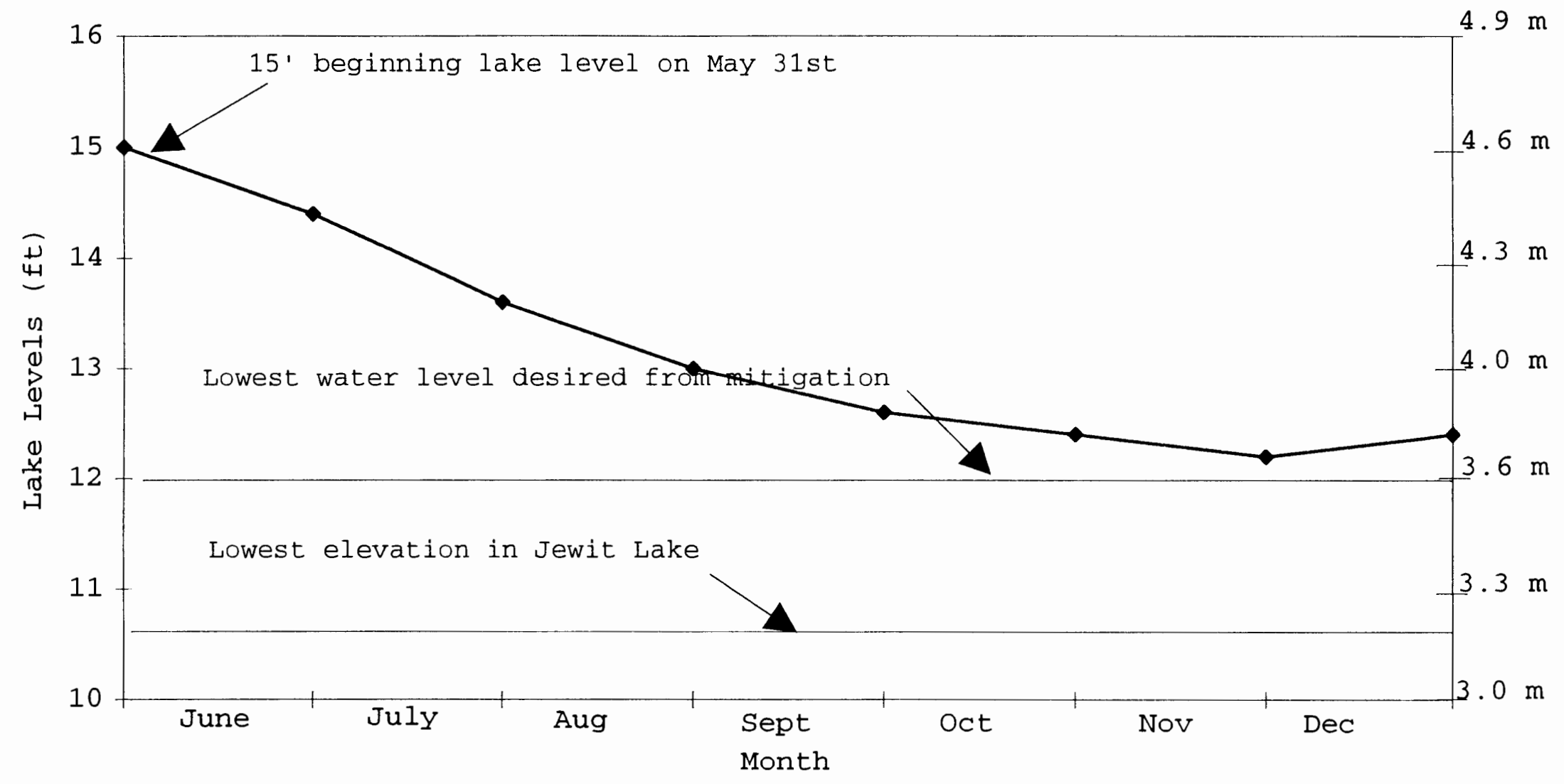

Figure 43. Jewit Lake levels from May 31 to December 31 with average precipitation. 


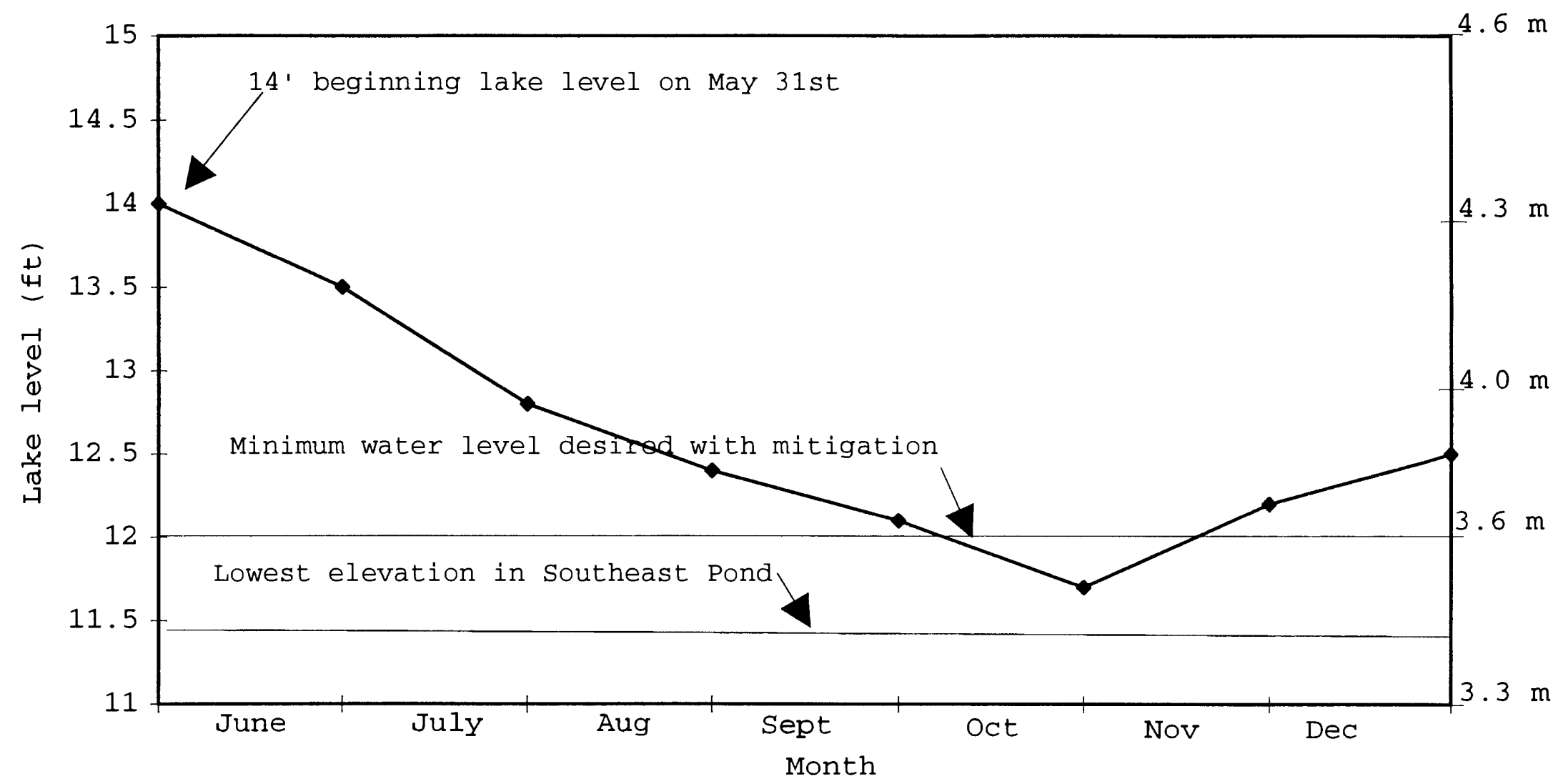

Figure 44. Southeast Pond levels from May 31 to December 31 with average precipitation. 
ft/day) were used for the confining unit and aquifer parameters, respectively. Beginning lake levels of $4.6 \mathrm{~m}$ (15 ft) and $4.3 \mathrm{~m} \mathrm{(14} \mathrm{ft)} \mathrm{are} \mathrm{shown} \mathrm{for} \mathrm{Jewit} \mathrm{Lake} \mathrm{and}$ Southeast Pond respectively. At a beginning water level of $4.6 \mathrm{~m}$ (15 ft) on May 31, Jewit Lake is not expected to dry. At a beginning water level of $4.3 \mathrm{~m}$ (14 ft), Southeast Pond is expected to dry during October.

\section{Summary of the groundwater model design parameters and the results of groundwater modeling}

The groundwater model was designed as a 4 layer problem, with a confining unit overlying an aquifer. Layers 1, 2, and 3 represent the confining unit and Jewit Lake and Southeast Pond, respectively; layer 4 represents the aquifer. Precipitation and evapotranspiration were entered into the groundwater model to simulate the response of lake levels to climatalogical factors expected to occur on Government Island. Water level measurements in February, March, and April 1994 were compared with modeling results so that the groundwater model could be calibrated against real data. Hydraulic conductivity and transmissivity values of the confining unit and the aquifer were altered to assess the variability in lake levels with changes in these parameters. Decreasing values of hydraulic conductivity and transmissivity in the confining unit increases water levels in Jewit Lake and 
Southeast Pond. For a fixed set of hydraulic parameters, water leaves the study area by evapotranspiration and groundwater infiltration in volumes dependent upon rates of precipitation and evapotranspiration. Modeling indicates that with average precipitation and evapotranspiration, Jewit Lake must reach a level of $4.6 \mathrm{~m}$ (15 ft) during the spring flooding of the Columbia River to ensure that water levels in Jewit Lake do not drop below $3.6 \mathrm{~m}$ (12 ft) during the summer months. Modeling indicates that with average precipitation and evapotranspiration, Southeast Pond must exceed a water level of $4.3 \mathrm{~m} \mathrm{(14} \mathrm{ft)} \mathrm{in} \mathrm{the} \mathrm{spring} \mathrm{months} \mathrm{to} \mathrm{ensure} \mathrm{that}$ water levels in Southeast Pond do not drop below $3.6 \mathrm{~m}$ (12 ft) during the summer months. 
Table X

Summary of the variables used in MODFLOW to simulate the hydrogeology of Government Island.

Node dimensions: $152.4 \mathrm{~m}$ by $152.4 \mathrm{~m}$

Confining unit thickness: 1.7 to $6.1 \mathrm{~m}$

Aquifer thickness: $7.5 \mathrm{~m}$

Aquifer transmissivity: $259 \mathrm{~m} /$ day, $2590 \mathrm{~m} /$ day, $25900 \mathrm{~m} /$ day

Confining unit hydraulic conductivity (Southeast Pond): 6 $\mathrm{cm} /$ day, $2.7 \mathrm{~cm} /$ day, $0.4 \mathrm{~cm} /$ day

Confining unit hydraulic conductivity (all nodes except Southeast Pond): $15 \mathrm{~cm} /$ day, $2.7 \mathrm{~cm} /$ day, $0.4 \mathrm{~cm} /$ day

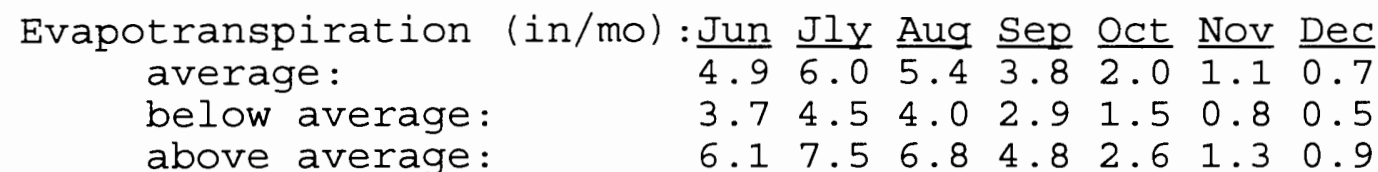

Precipitation: (in/mo): Jun Jly Aug sep oct Nov Dec

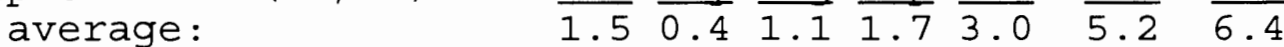

below average: $\quad \begin{array}{llllllll}0.7 & 0.2 & 0.5 & 0.8 & 1.5 & 2.6 & 3.2\end{array}$

$\begin{array}{llllllll}\text { above average: } & 2.2 & 0.6 & 1.6 & 2.6 & 4.5 & 7.8 & 9.6\end{array}$

double the average: $\quad \begin{array}{llllllllll}3.0 & 0.8 & 2.2 & 3.4 & 6.0 & 10.4 & 12.8\end{array}$ 


\section{DISCUSSION OF HYDROLOGY}

Flooding of Jewit Lake through the spillway channel can occur between December and June, depending upon the timing of water release from the Columbia-Snake River dam system. Between 1973 and 1989, each year that the Columbia River exceeded $4.7 \mathrm{~m}(15.3 \mathrm{ft})$ in elevation in December or January, the Columbia River also exceeded 4.7 $\mathrm{m}$ (15.3 ft) in elevation in May or June. Approximately once every three years, river levels exceed 4.7 (15.3 ft) m.s.l. during February, March, or April, thus flooding Jewit Lake.

Table IV shows estimates of inflow rates which occurred through the dam in January and February of 1995 based on the volume of water present in Jewit Lake following high river stages (Figure 16). Water from the peak flows occurring on February 1st through February 4 th and February 20th through February 22nd flowed through the open spillway grates and the spring loaded gates. Water from the January 14th through January 21st peak flow event flowed only through the spring loaded gates. The rate of water flow through the dam was approximately 15 to 20 times higher when water flow occurred through the spillway grates as well as the spring loaded gates than when water flow occurred only through the spring loaded gates. Thus when the Columbia River exceeds 4.7 meters $(15.3 \mathrm{ft}$ ) in elevation at Government Island, the level of Jewit Lake 
will increase much faster than when the Columbia River is between 3.6 and $4.7 \mathrm{~m} \mathrm{(12} \mathrm{and} 15.3 \mathrm{ft}$ ) elevation at Government Island.

By examining the spatial distribution of hydraulic head at observation points throughout the study area, the direction of groundwater flow can be determined. If head is higher near the Columbia River than the interior of the island, groundwater flow is towards the interior of the island. If head is higher in the interior of the island than near the Columbia River, groundwater flow is from the interior of the island towards the Columbia River. Through aquifers, groundwater flow is predominately horizontal, with a small vertical component, while through confining units, groundwater flow is predominantly vertical, with a small horizontal component (Freeze and Cherry, 1979).

Maximum river levels on the Columbia River occur in May or June in most years (Figure 12, Appendix 1). Water can be retained in Jewit Lake to a maximum level of $4.7 \mathrm{~m}$ (15.3 ft), creating head differences of up to $1.8 \mathrm{~m}(5.8$ ft) between the lake levels maintained by the spillway channel dam and the level of the Columbia River. Since the filled lake and pond each lose water to the aquifer that flows to the Columbia River, the water table must slope away from the interior of the island towards the 
Columbia River. The slope of the water table decreases as the lake levels decrease since the head difference between the lakes and the river at $2.9 \mathrm{~m}(9.5 \mathrm{ft})$ is lower.

Seismic refraction data collected on May 7 th and 8 th, 1994 (Table VI) show that the water table was nearly flat in the north-south direction during the time of the refraction study. The seismic refraction data show that the water table was sloping gently towards the interior of the island. The Columbia River changed little in level in the month prior to the seismic refraction study. Figure 11 shows that Columbia River levels varied only $0.61 \mathrm{~m}$ (2 ft) in elevation from approximately April 15th to May 7th and 8 th, when the seismic refraction study was done. The water table should flatten in response to nearly constant Columbia River levels and be approximately the same elevation as the Columbia River. Rainfall recharge allows the water table to be located above the minimum level maintained by the Columbia River (McDonald and Harbaugh, 1984).

Differences between field observations of the water table and refraction depths are attributed to the heterogeneity of the sediments and the velocity differences in the sediments. The water table at station

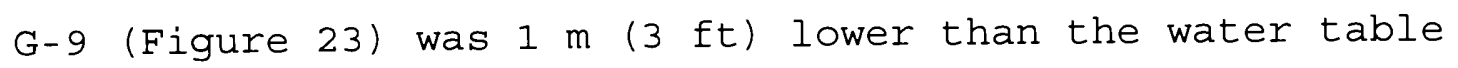
at any of the other stations (Table VI). This suggests 
that the sediments underlying this station may have a higher conductivity than the sediments at the other stations (Figure 45). Figure 45 shows that a zone of higher hydraulic conductivity may cause the elevation of the water table to be lower in the vicinity of station G-9 than at the other stations. A zone of higher hydraulic conductivity would likely be sandy material deposited within the Government Island channel bar. The extent of this zone of higher conductivity is unknown.

Figure 10 shows that the Columbia River reached a

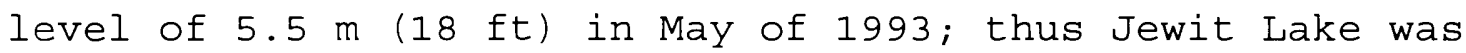
flooded. Jewit Lake was dry in early October of 1993. The ditch plug (Figure 4) held water in Jewit Lake prior to construction of the dam in October of 1993. By estimating the elevation of the top of the ditch plug, the maximum level of Jewit Lake in 1993 can be estimated. The top of the ditch plug is estimated to have an elevation of $4.3 \mathrm{~m}$ (14 ft). It is unknown when drying of Jewit Lake occurred in 1993. Jewit Lake was dry on October 23rd, 1993 .

It is not known if Southeast Pond received overland flow from Jewit Lake in 1993. If Southeast Pond did receive overland flow from Jewit Lake in 1993, the drying date of southeast Pond in 1993 permits an estimation of when drying could occur in future years. A drying date in 


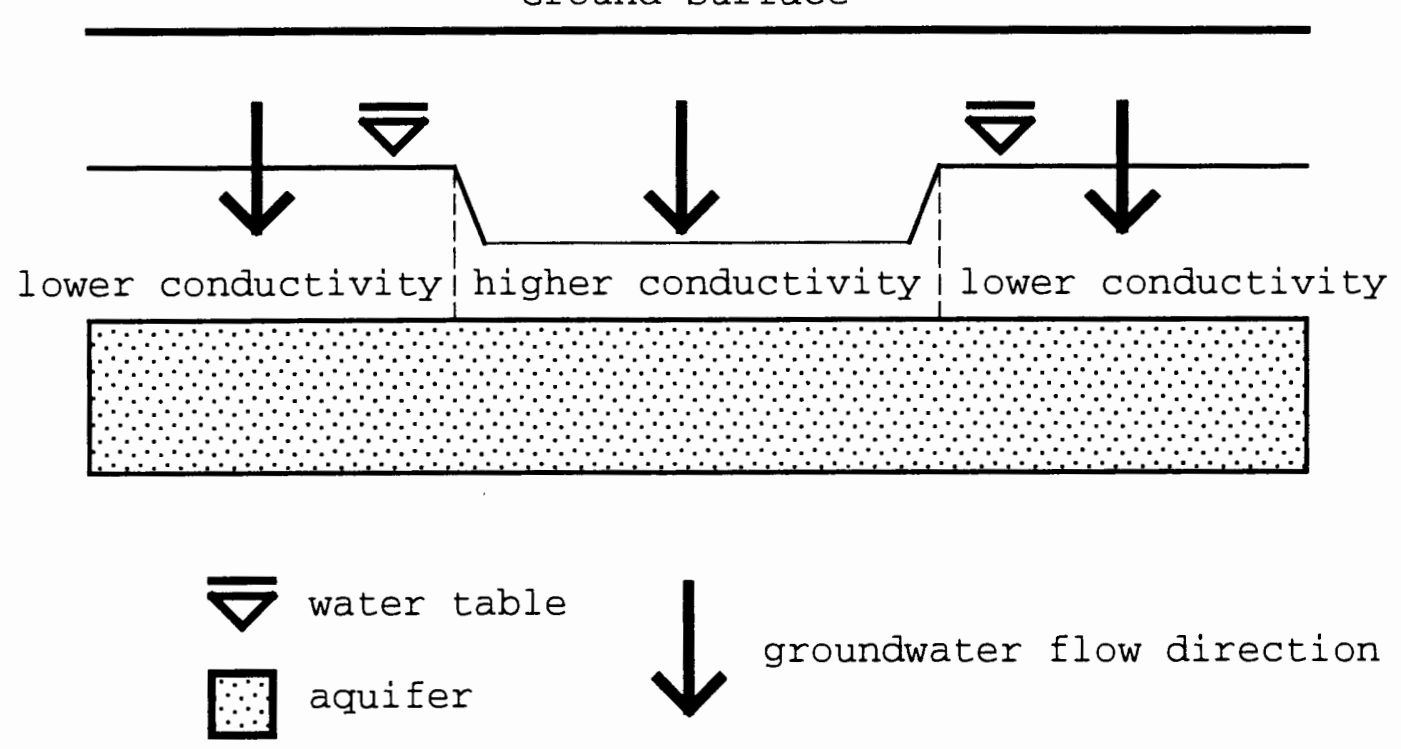

Figure 45. A zone of higher hydraulic conductivity at seismic refraction station G-9 (Figure 23). 
October or early November can be predicted based on a drying date of October $30 t h$ in 1993.

The Columbia River did not flood Jewit Lake through the channel in 1994. Thus all of the water in Jewit Lake and Southeast Pond were derived from precipitation and groundwater. Water levels in Southeast Pond were higher than water levels in Jewit Lake throughout 1994 (Table II). The observation that water levels in Southeast Pond were higher than water levels in Jewit Lake were used to determine that infiltration rates are higher in Jewit Lake than in southeast Pond. Jewit Lake should have maintained surface water longer into the fall of 1993 than southeast Pond if infiltration rates in the lakes were equal since the bottom elevation of Jewit Lake is lower than the bottom elevation of Southeast Pond. Since infiltration rates into the sediments of Southeast Pond are lower than infiltration rates into Jewit Lake, the hydraulic conductivity of the southeast Pond sediments must be lower than the hydraulic conductivity of the Jewit Lake sediments.

Groundwater modeling was used to determine if Jewit Lake and Southeast Pond would maintain surface water throughout the growing season in years when flooding of the lake does not occur. Figures 36 and 37 indicate that drying will occur in both lakes when flooding through the 
dam does not occur. Figures 36 and 37 show that drying times will fluctuate depending on precipitation rates entered into the groundwater model. Analysis of hydrographs of the Columbia River (Appendix 1) indicates that the Columbia River did not reach $4.7 \mathrm{~m}$ (15.3 ft) in elevation at Government Island in only 2 of the 16 years between 1973 and 1989. The Columbia River reached $3.6 \mathrm{~m}$ (12 ft) in elevation every year between 1973 and 1989. In 1994 (Figure 11), the Columbia River did not reach 3.6 (12 ft) in elevation, thus no flooding of Jewit Lake occurred. In 1994, Jewit Lake dried in May and Southeast Pond dried in June. It is unlikely that water will be absent from Jewit Lake and southeast Pond in future years for the length of time that it was absent in 1994 because the Columbia River maintained higher levels in the 16 years prior to implementation of mitigation and 1994 had below average precipitation. 1994 levels of the Columbia River were extremely low and are not expected to occur often in the future.

The length of time that water is absent from the lakes depends upon the amount of precipitation occurring at Government Island and the level of the lakes at the beginning of the summer months. The years that the Columbia River does not reach $3.6 \mathrm{~m} \mathrm{(12} \mathrm{ft)} \mathrm{in} \mathrm{elevation}$ at Government Island are likely to be years when below 
average precipitation occurs in the Columbia River drainage basin. Therefore, summer months with above average or twice the average precipitation would not be expected to occur on Government Island in years when the Columbia River drainage basin recieves below average precipitation.

The groundwater model was run using beginning lake levels of $4.0,4.3$, and $4.6 \mathrm{~m}(13,14$, and $15 \mathrm{ft})$. The lake and pond recieve variable amounts of precipitation and undergo variable rates of evapotranspiration beginning June 1st. Results of modeling (Table IX) indicate that surface water will remain in Jewit Lake and southeast Pond when lake levels of $4.5 \mathrm{~m}$ ( $14.7 \mathrm{ft}$ ) are reached in May and average precipitation and evapotranspiration rates occur. Drying will occur for one month at the end of the growing season when May lake levels reach $4.3 \mathrm{~m}$ (14 ft) in elevation and average precipitation and evapotranspiration rates occur. Unless twice the average precipitation occurs in the summer months, dry conditions of greater than one month during the growing season will occur in both lakes when the lakes do not reach a level of 4.3 (14 ft) in May.

1994 water level observations (Table II) indicate that Jewit Lake will dry before Southeast Pond when flooding through the spillway channel does not occur. 
Jewit Lake would be dry for longer periods of time than indicated in Table IX if drying of Jewit Lake occurs before drying of Southeast Pond. If water leaves Jewit Lake and Southeast Pond at the same rate, Jewit Lake would be expected to contain water longer each year than Southeast Pond due to the elevation differences of the bottom of the lakes. In order for water levels to be lower in Jewit lake than Southeast Pond, water must leave Jewit Lake at a faster rate than water leaves Southeast Pond. In modeling, this would occur if the hydraulic conductivity and VCONT of the confining unit under Jewit Lake were increased or if the transmissivity of the aquifer underlying Jewit Lake were increased.

In 1994, Jewit Lake and Southeast Pond had different water levels, indicating that the hydrology of the lakes are independent of each other. Water level measurements (Table II) indicate that water in Jewit Lake and Southeast Pond infiltrate at different rates; thus the rates of groundwater flow through the subsurface sediments are different. The transmissivity of the underlying aquifer connecting to the Columbia River is assumed to be homogenous since very little is known about the aquifer. Differences in the hydraulic conductivity and the VCONT parameters of the confining unit in MODFLOW allow Southeast Pond and Jewit Lake to retain different water 
levels. The different water levels observed in the lakes may not solely be caused by a difference in the hydraulic conductivity of the confining unit. Variations in the transmissivity of the underlying aquifer may be contributing to differences in water levels of Jewit Lake and Southeast Pond. The different levels in the lakes may indicate that the aquifer is not continuous throughout the island.

Precipitation which directly falls onto surface water increases the lake to a level directly proportional to the amount of water which falls on the lake. Water that falls onto the ground surface infiltrates into the soil through intergranular pore space or flows overland. Since water occupies only intergranular pore space in the ground, precipitation can raise the elevation of a subsurface water table much more than when the water table is above the ground surface. As the water table rises in elevation, more of this water is exposed above ground as surface water. Therefore, a given amount of precipitation has a greater effect on the elevation of the water table in the subsurface than when the water table is above the ground surface.

In February of 1994 through May of 1994, water levels in southeast Pond were higher than water levels in Jewit Lake. Since the ground surface of Southeast Pond is 
higher than the ground surface in Jewit Lake, the water table remains in the subsurface to a higher elevation in Southeast Pond. Thus the water table is likely to be higher in Southeast Pond than Jewit Lake if rainfall is the source of water for both lakes.

Figures 33,34 , and 35 show precipitation, evapotranspiration, and groundwater infiltration from June through December under variable rates of precipitation. These figures indicate that as precipitation increases, groundwater infiltration increases and as evapotranspiration increases, groundwater infiltration decreases. When precipitation is average or above average and evapotranspiration is average or below average, the amount of water leaving the model by groundwater infiltration is at least double the amount of water leaving the model by evapotranspiration. More water leaves the model by evapotranspiration in June, July, August, and september than by groundwater infiltration when precipitation is below average and evapotranspiration is above average. Figures 33,34 , and 35 suggest that the climate in June through December affects how much water enters and leaves the study area by precipitation and evapotranspiration, respectively; thus influencing the amount of water available for groundwater infiltration. Comparison of the periods of drying given for Jewit 
Lake and Southeast Pond in Table IX indicate that precipitation has a greater influence on the water level of Southeast Pond than the water level of Jewit Lake. This is because the sediments underlying southeast Pond have a lower hydraulic conductivity than the sediments underlying Jewit Lake. The modeling results given in Table IX show that dry conditions within the lakes end before January. An average of $28 \mathrm{~cm}(11 \mathrm{in})$ of precipitation (Figures 18 and 19) occurs in November and December, contributing water to the lakes. Following a period of drying, surface water should be present in the lakes in November or December of an average precipitation year. 


\section{DISCUSSION OF EXPECTED WETLAND CONDITIONS FOLLOWING MITIGATION}

The data given in Appendix 1 show that flooding through the spillway grating would have occurred in 14 of 16 years between 1973 and 1989. Based on observations of the filling rates of Jewit Lake in February of 1995, Jewit Lake levels above $4.2 \mathrm{~m}$ (14 ft) are expected to occur in most years. The results given in Table IX indicate that surface water will be present in Jewit Lake from late spring to early fall in most years. Jewit Lake will have a semipermanently flooded water regime following mitigation in the $0.34 \mathrm{~km}^{2}$ (72 acres) below $3.8 \mathrm{~m}$ (12 ft) in elevation if surface water is present from late spring to early fall in most years.

Prior to mitigation, water flow from the columbia River into Jewit Lake was uninhibited above the elevation of the ditch plug $(4.3 \mathrm{~m}, 14 \mathrm{ft})$. The presence of Centunculus minimus (Sherry Spencer, personal communication, 1995) in Southeast Pond indicates that neither flooding of Southeast Pond or high rates of summer precipitation have maintained water in Southeast Pond throughout the growing season in the past. Following mitigation, flow rates into Jewit Lake are restricted to flow through the dam. Southeast Pond is less likely to recieve overland flow from Jewit Lake following mitigation since a longer period of time is needed to flood Jewit Lake to a level of $4.7 \mathrm{~m}$ (15.4 ft). Therefore Southeast 
Pond will maintain a seasonally flooded water regime. Galen and others (1992) predicted that a submergent plant community would develop in $0.34 \mathrm{~km}^{2}(72$ acres) of Jewit Lake and Southeast Pond below an elevation of $3.8 \mathrm{~m}$ (12 ft). Occasional drying of the lakes at the end of the growing season was expected to affect this plant community. Annual drying of Southeast Pond will prevent a submergent plant community from establishing itself in that area. A submergent plant community could become established in Jewit Lake as a result of mitigation even though drying is expected to occur in some years. The nonpersistent emergent wetland that is currently present in Jewit Lake should undergo changes in its plant community as a result of mitigation.

Galen and others (1992) indicate that spikerush, bulrush, beggars tick, wapato, and cattail will become dominant plant species between 3.8 and 4.4 (12 and 14.5 ft) in elevation if surface water is present 6-12 months of the year above $3.8 \mathrm{~m}(12 \mathrm{ft})$. The persistent emergent wetland between elevations of 3.8 and $4.4 \mathrm{~m}$ (12 and 14.5 ft) will not meet the requirement of 6-12 months of inundated conditions in years when flooding through the spillway gates does not occur. Surface water will be present 0-3 months of the year when this occurs. When flooding through the spillway grates does occur, surface 
water will be present 3 to 12 months of the year depending on elevation of flooding. The persistent emergent plant communities are more likely to become established between 3.8 and $4.0 \mathrm{~m}$ ( 12 and $13 \mathrm{ft}$ ) in elevation because standing water will be present for longer periods of time. The persistent emergent plant communities should not be successful between 4.1 and $4.4 \mathrm{~m}(13.5$ and $14.5 \mathrm{ft})$ in elevation since surface water is not expected to be present 6-12 months of the year.

Surface water cannot be expected to be present for 6 months of the year in areas with elevations between 4.4 and $4.9 \mathrm{~m}$ ( 14.5 and $16 \mathrm{ft})$. Using the rates of flow through the dam given in Figure 17, a minimum of 7 days is required to raise Jewit Lake to $14.5 \mathrm{ft}$. Surface water may not reach these levels in years when flooding occurs through the spillway grating and will not reach these levels when flooding does not occur through the spillway grating. The potential for herbaceous hydrophytes to become established in areas with elevations between 4.4 and $4.9 \mathrm{~m}(14.5$ and $16 \mathrm{ft})$ is low.

Galen and others (1992) indicate that $0.16 \mathrm{~km}^{2}(34$ acres) of forested wetland will be converted to persistent emergent wetland following mitigation. Surface water inundation 6 to 12 months of the year is expected to eliminate the present tree community between the 
elevations of 3.6 to $4.1 \mathrm{~m}$ (12 to $13.5 \mathrm{ft}$ ) in elevation. Persistent emergent wetland may not replace the forested wetland present between 4.1 and $4.4 \mathrm{~m}$ (13.5 and $14.5 \mathrm{ft}$ ) as Pacific Willow trees may continue to occupy these areas. Approximately $0.10 \mathrm{~km}^{2}$ (22 acres) of forested wetland are located between 4.1 and $4.6 \mathrm{~m}$ ( 14.5 and $16 \mathrm{ft}$ ) and approximately $0.06 \mathrm{~km}^{2}$ (12 acres) of forested wetland are located between 3.6 and $4.4 \mathrm{~m}(12$ and $14.5 \mathrm{ft}$ ). Thus only 0.06 of the $0.1 \mathrm{~km}^{2}$ (12 of the 34 acres) of forested wetland are likely to be replaced by persistent emergent wetland. 


\section{RECOMMENDATIONS FOR FUTURE WORK AND IMPROVEMENTS TO THE MITIGATION PLAN}

Improvements to the groundwater model presented in this study could be made if the sedimentology of the island were better understood. Identification of the geomorphic features and the lateral extent of these features will improve the understanding of how the island developed and how it behaves hydrologically. With this understanding, a more detailed groundwater model could be constructed to account for the variablity in conditions. The node spacing for additional groundwater modeling could be decreased so that smaller areas of particular interest could be modeled with more precision. Many of the fluvial geomorphic features examined in the study area were not accounted for in this study because they only represented a small area of an individual node in the groundwater model.

More numerous water level measurements would allow determination of hydrologic conditions in areas whose depositional histories are different. At 3 to $6.1 \mathrm{~m}$ (10 to $20 \mathrm{ft}$ ) deep monitoring points, it could be determined how much the water level in the aquifer changes with fluctuations of the Columbia River. The approximate relationship of the water table and the level of the Columbia River could be determined.

A substantial quantity of water leaves Government Island by evapotranspiration. Improved understanding of 
the difference in evapotranspiration rates from wetland and nonwetland areas would improve the understanding of the water balance of the study area.

The forested wetland occurs in distinctly linear trends and clusters that do not always follow changes in elevation. Much can be learned from the vegetation in this site because of the niche that each plant occupies. Forested wetands may occur where shallow subsurface drainage within sediments is higher than the drainage in the non-forested wetland. Trees in the Government Island wetland may occur at hydrologic boundaries caused by changes in sediment composition in the shallow subsurface. In order to maintain perennial surface water in Southeast Pond, modifications to the mitigation plan need to be developed. Southeast Pond could be connected to Jewit Lake so that Southeast Lake would recieve water at levels of flooding below the current $15.5 \mathrm{ft}$ barrier. Pumping of water into Southeast Pond could be effective in maintaining perennial surface water in Southeast Pond. Plant communities need to be monitored closely in order to determine if the desired submerged species become established in Jewit Lake despite periodic drying. 


\section{REFERENCES}

Allen, J.E., Burns, M., and Sargent, S.C., 1986, Cataclysyms on the Columbia. Timber Press Publishing Co., Portland, Oregon. $211 \mathrm{p}$.

Arno, S.F., 1977, Northwest Trees. The Mountaineers, seattle, Washington. $222 \mathrm{p}$.

Chow, V.T., 1964, Handbook of Applied Hydrology. McGrawHill, San Francisco, California, 1453 p.

Cowardin, L.M., Carter, V., Golet, F.C., and LaRoe, E.T., 1979, Classification of wetlands and deepwater

habitats of the United States. U.S. Fish and Wildife Service publ., $131 \mathrm{p}$.

Day, P.R., 1965, Particle fractionation and particle size analysis, in Black, C.A. ed., Methods of soil analysis, part 1, Madison, Wisconsin, American Society of Agronomy, Series in Agronomy, Number 9, p. 545-567.

Dunne, T., and Leopold, L., 1978, Water in environmental planning. W.H. Freeman Co., New York, New York. 818 p.

Experimental Laboratory, 1987, Corps of Engineers wetlands delineation manual. Technical Report Y-87-1. U.S. Army Engineer Waterways Experiment Station, Vicksburg, Mississippi, $100 \mathrm{p}$.

Freeze, R.A., and Cherry, J.A., 1979, Groundwater. Prentice Hall Publishing Co., Englewood Cliffs, New Jersey. $604 \mathrm{p}$.

Galen, C., Fishman, P., and Smith, D., 1992, Habitat evaluation of the Port of Portland PDX SW quadrant wetland fill site and Government Island mitigation site: Submitted to the Port of Portland, Portland, OR. Fishman Environmental Services, Portland, OR. 12 $\mathrm{p}$.

Gates, E.B., 1994, The Holocene sedimentary framework of the Lower Columbia River: Unpublished M.S. Thesis, Portland State University, Portland OR. $210 \mathrm{p}$.

Hitchcock, C.L., and Cronquist, A., 1973, Flora of the Pacific Northwest. University of Washington Press, Seattle, Washington. $730 \mathrm{p}$. 
Leopold, L.B., and Wolman, M.G., 1957, Physiographic and hydraulic studies of rivers; River channel Patterns: Braided, Meandering, and Straight. U.S. Geological Survey Professional Paper 282-B, p. 39-53.

McDonald, M., and Harbaugh, A., 1984, A modular threedimensional finite-difference ground-water flow model. U.S. Department of Interior publ., Reston, Virginia. $528 \mathrm{p}$.

Oakley Engineering, 1992, Jewit Lake Hydrology: Submitted to the Port of Portland, Portland, OR. Oakley Engineering, Portland, OR., $89 \mathrm{p}$.

Parsons, R.B. and Green, G.L. 1982, Geomorphic surfaces and soils in Multnomah County, U.S. Department of Agriculture/Soil Conservation Service publ., $33 \mathrm{p}$.

SRI, 1991a, Assessment of Wetland Mitigation Opportunity for Proposed Wetland Fill Associated with Development of the Southwest Quadrant Site at Portland International Airport: Submitted to the Port of Portland, Portland, Or. SRI, Lake Oswego, OR., 41 p.

SRI, 1991b, Wetland determination and delineation for the Jewit Lake area, Government Island, Portland, OR.: Submitted to the Port of Portland, Portland, OR. SRI, Lake Oswego, OR., $16 \mathrm{p}$.

Sherwood, C.R., Jay, D.A., Harvey, R.B., Hamilton, P., and Simenstad, C.A., 1990, Historical changes in the Columbia River Estuary: Progress in Oceanography, $v$. 25, p. 15-79.

Simenstad, C.A., Small, L.F., McIntire, C.D., Jay, D.A., and Sherwood, C.R., 1990, An introduction to the Columbia River esturary: Brief history, prior studies, and the role of the CREDDP studies: Progress in Oceanography, v. 25, p. 175-210.

Soil Survey Staff, 1983, Soil Survey of Multnomah County, Oregon. U.S. Department of Agriculture, $225 \mathrm{p}$.

Soil Survey Staff, 1992, Keys to Soil Taxonomy. Pocahontas Press, Blacksburg, Virginia, $531 \mathrm{p}$.

Telford, W.M., Geldhart, L.P., and Sheriff, R.E., 1990, Applied Geophysics. Cambridge University Press, 770 $\mathrm{p}$. 
Waitt, R.B. Jr., 1985, Case for periodic jokulhaulps from Pleistocene glacial Lake Missoula: Geological Society of America Bulletin, v. 96, p. 1271-1286. 


\section{Appendix 1}

Appendix 1 contains hydrographs of the Columbia River from 1973 to 1989 (from Oakley, 1992). Levels of the Columbia River were recorded at the U.S. Geological Survey gauging station in Vancouver, Washington (Figure 2). River elevations at Vancouver have been adjusted to approximate the river elevations at Government Island by adding $0.38 \mathrm{ft} / \mathrm{mi}$ to the water level readings. 
Jewit Lake Hydrologic Analysis

\section{Estimated Lake Levels Based on 1973 River Data}

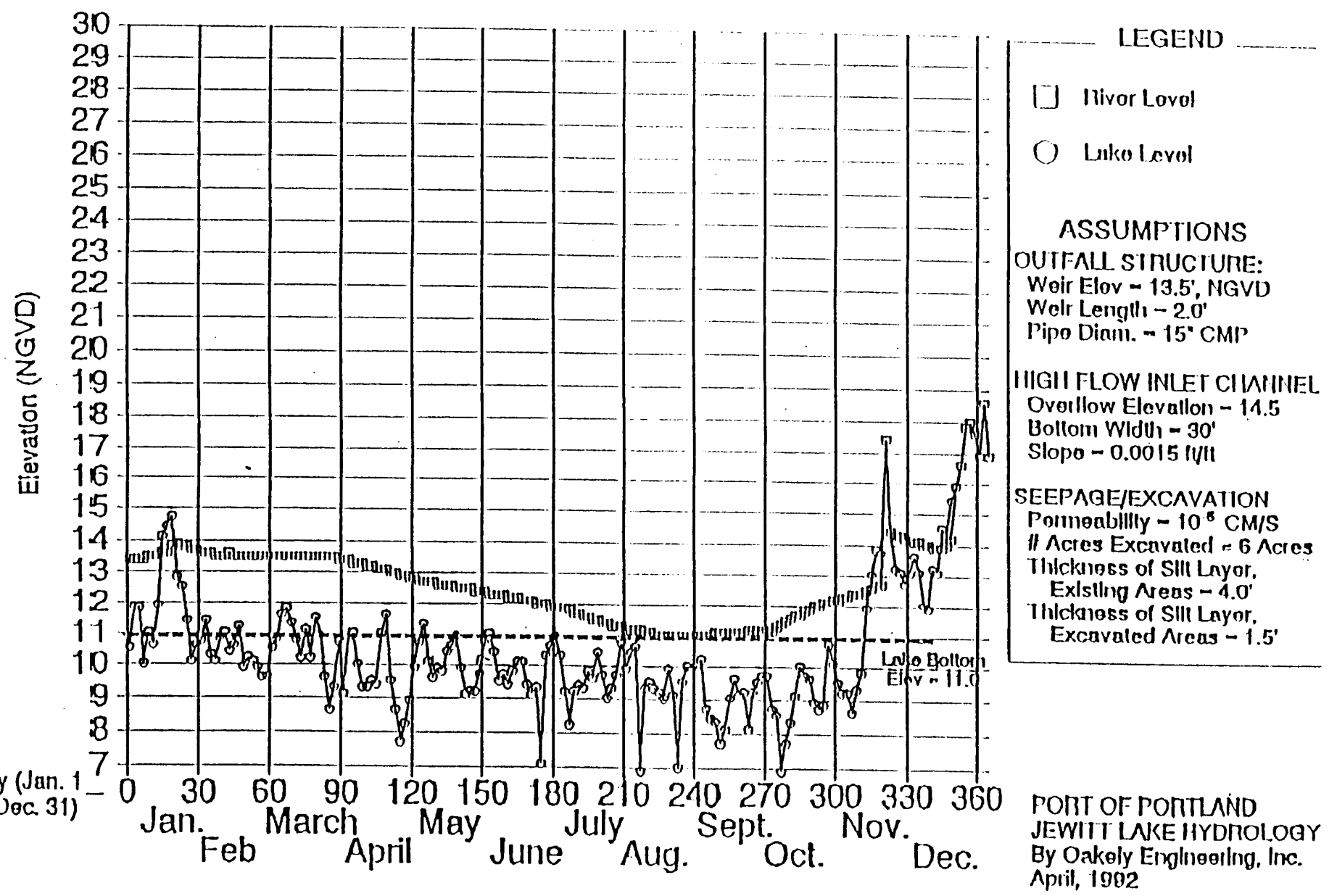




\section{Jewil Lake Hydrologic Analysis}

\section{Estimated Lake Levels Based on 1974 River Data}

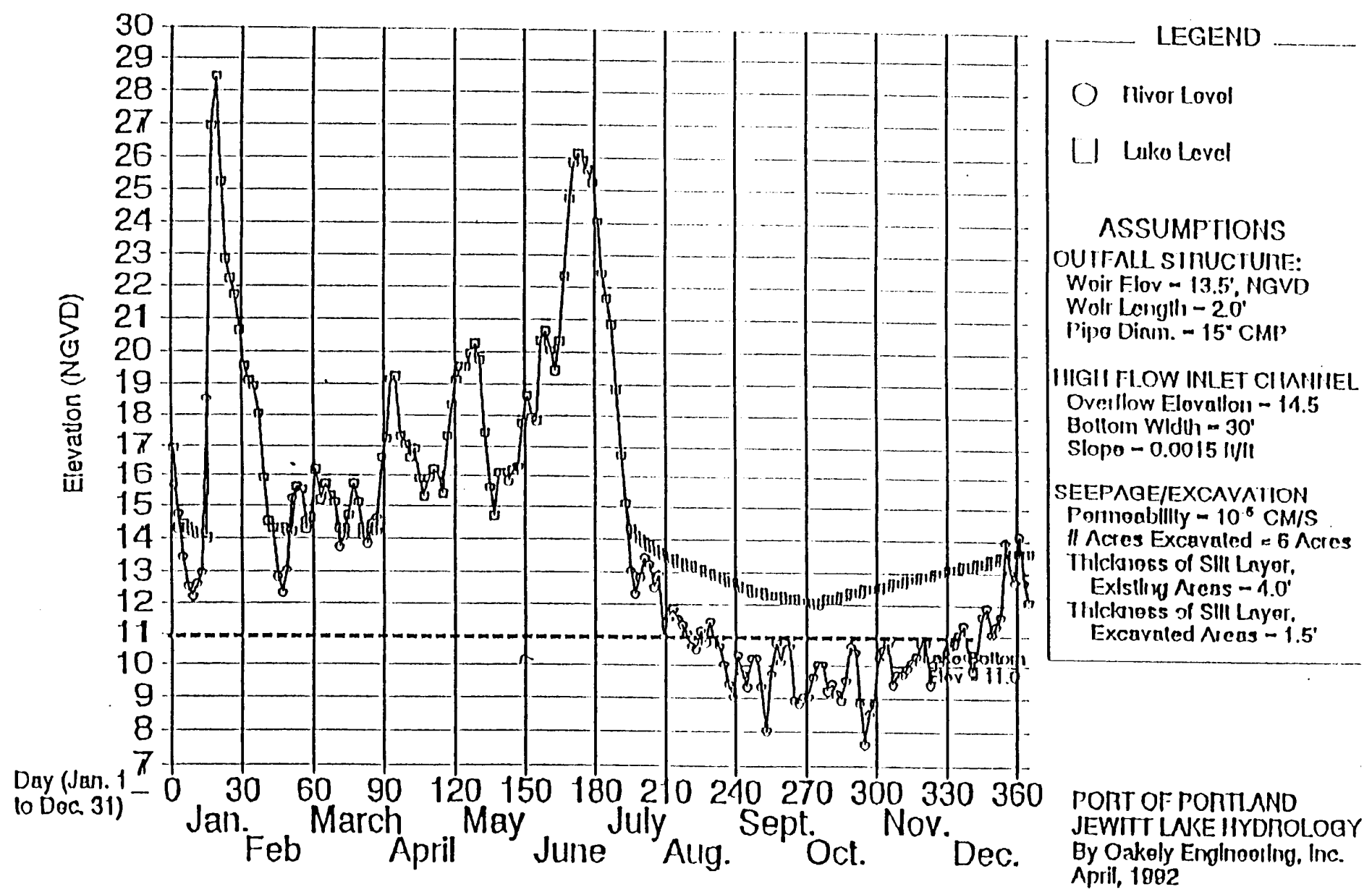


Jewil Lake Hydrologic An alysis

Estimated Lake Levels Based on 1975 River Data

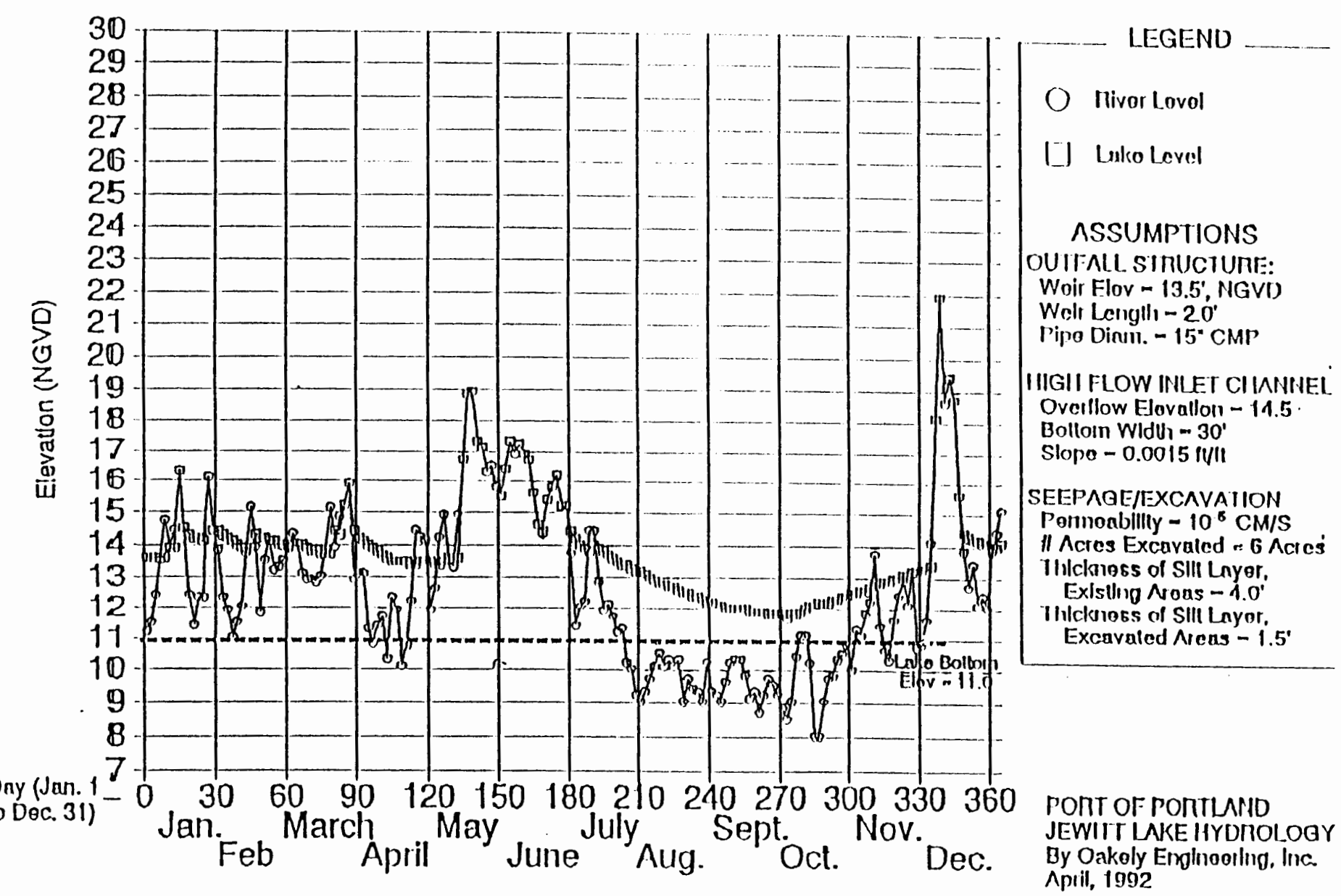


Jewit Lake Hydrologic Analysis

Estimated Lake Levels Based on 1976 River Data

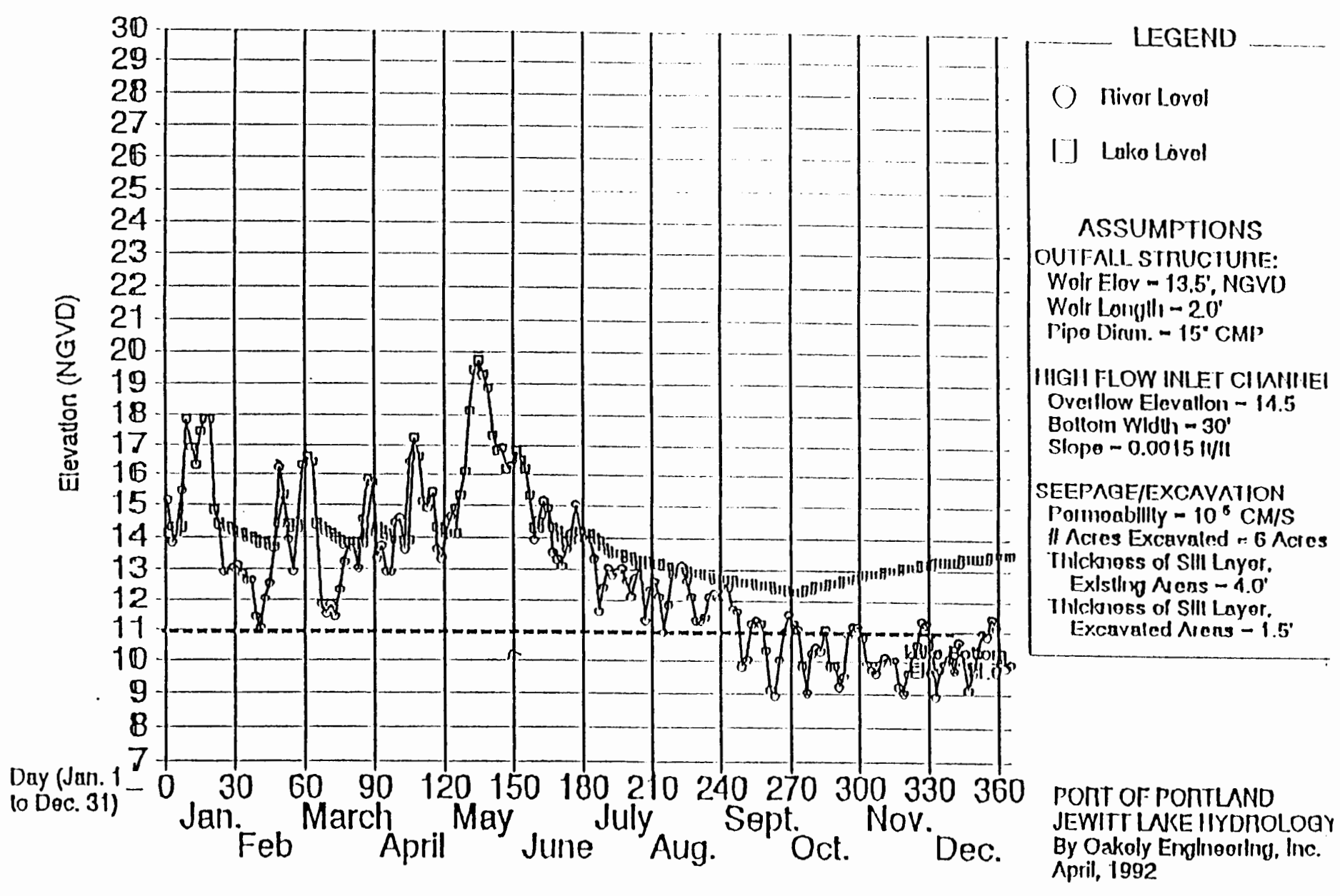


Jewil Lake Hydrologic Analysis

Estimated Lake Levels Based on 1977 River Dala

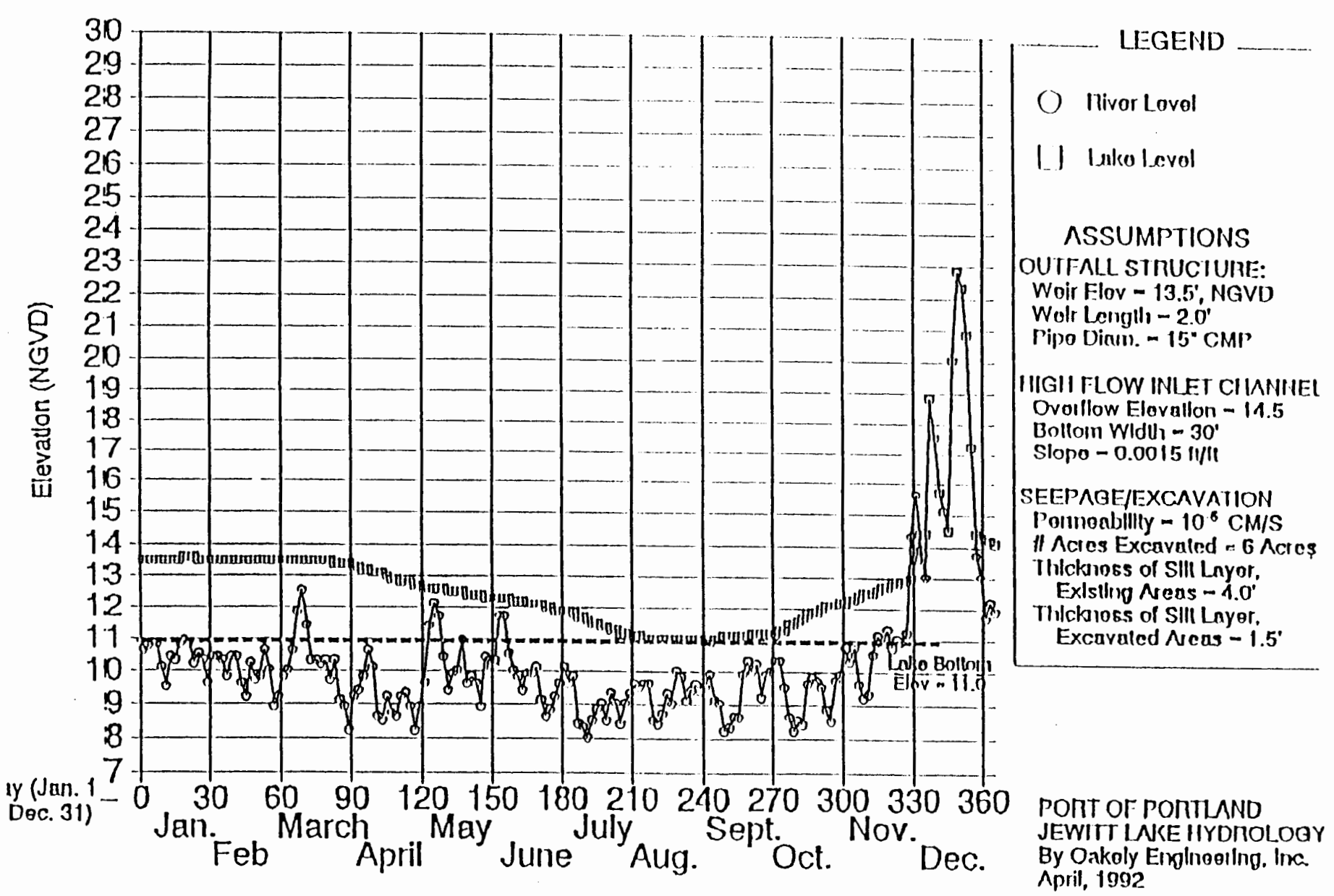


Jewil Lake Hydrologic Analysis

Estimated Lake Levels Based on 1978 River Dala

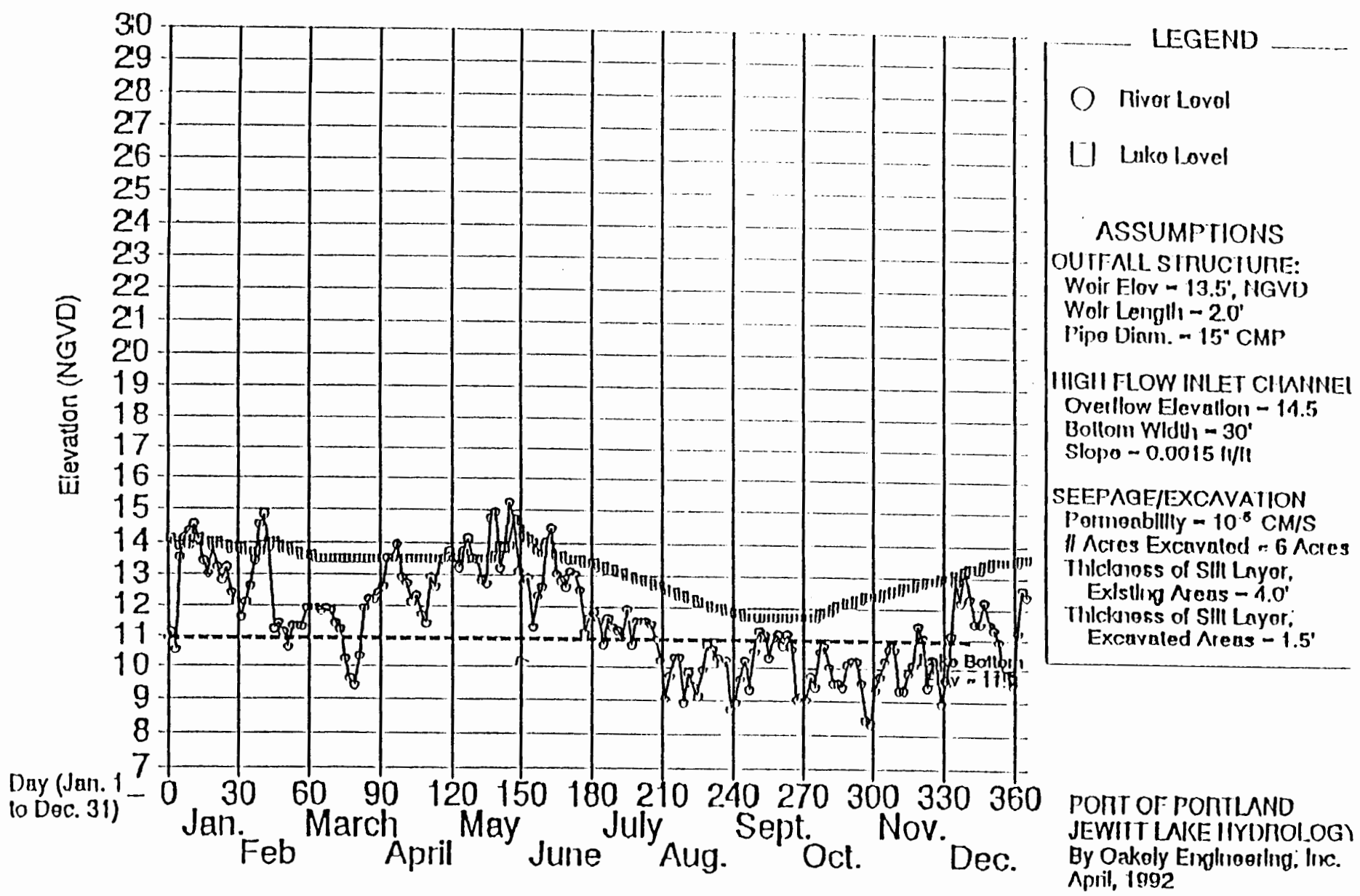


Jewit Lake Hydrologic Analysis

Estimated Lake Levels Based on 1979 River Dala

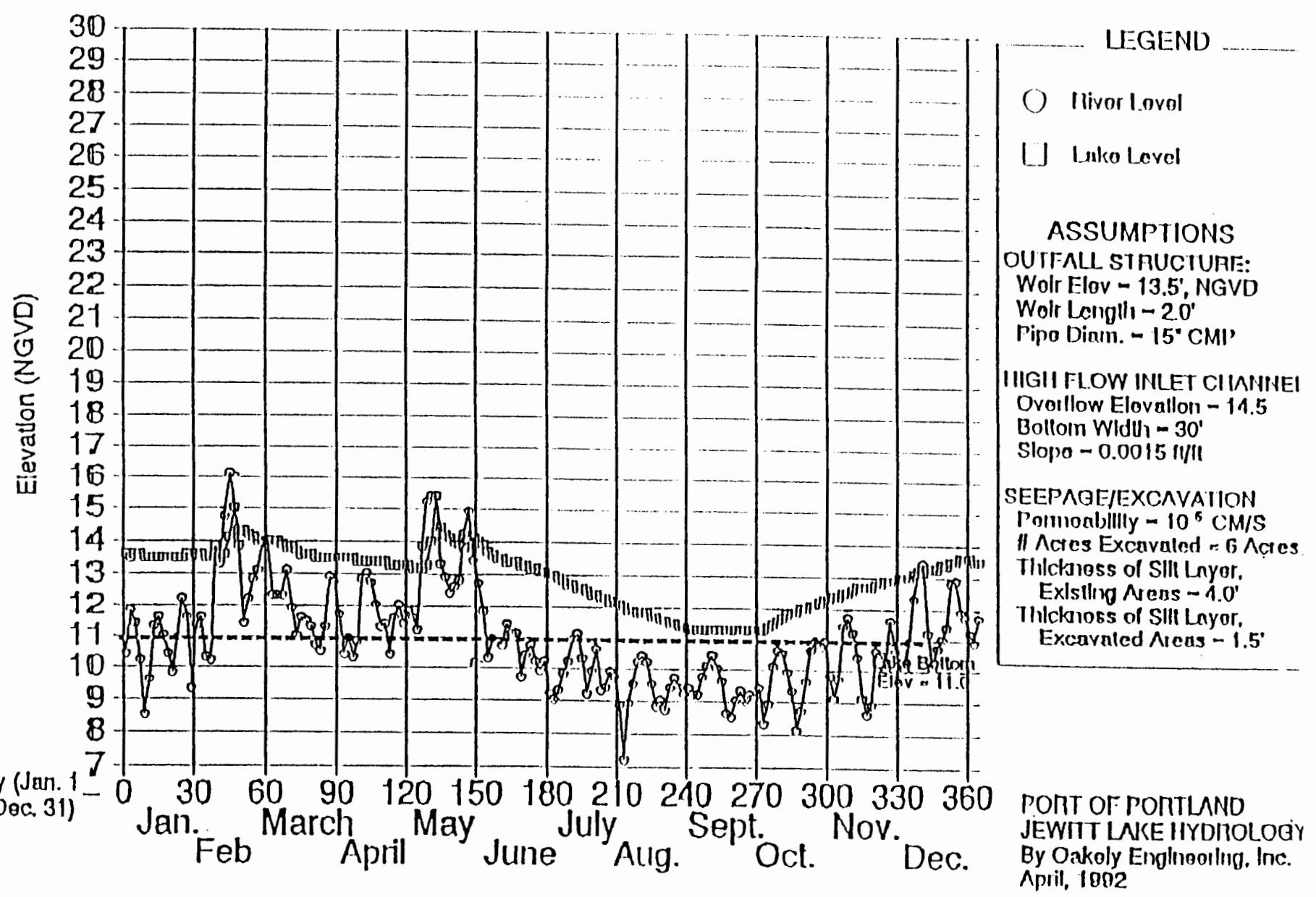


Jewil Lake Hydrologic Analysis

Estimated Lake Levels Based on 1980 River Dala

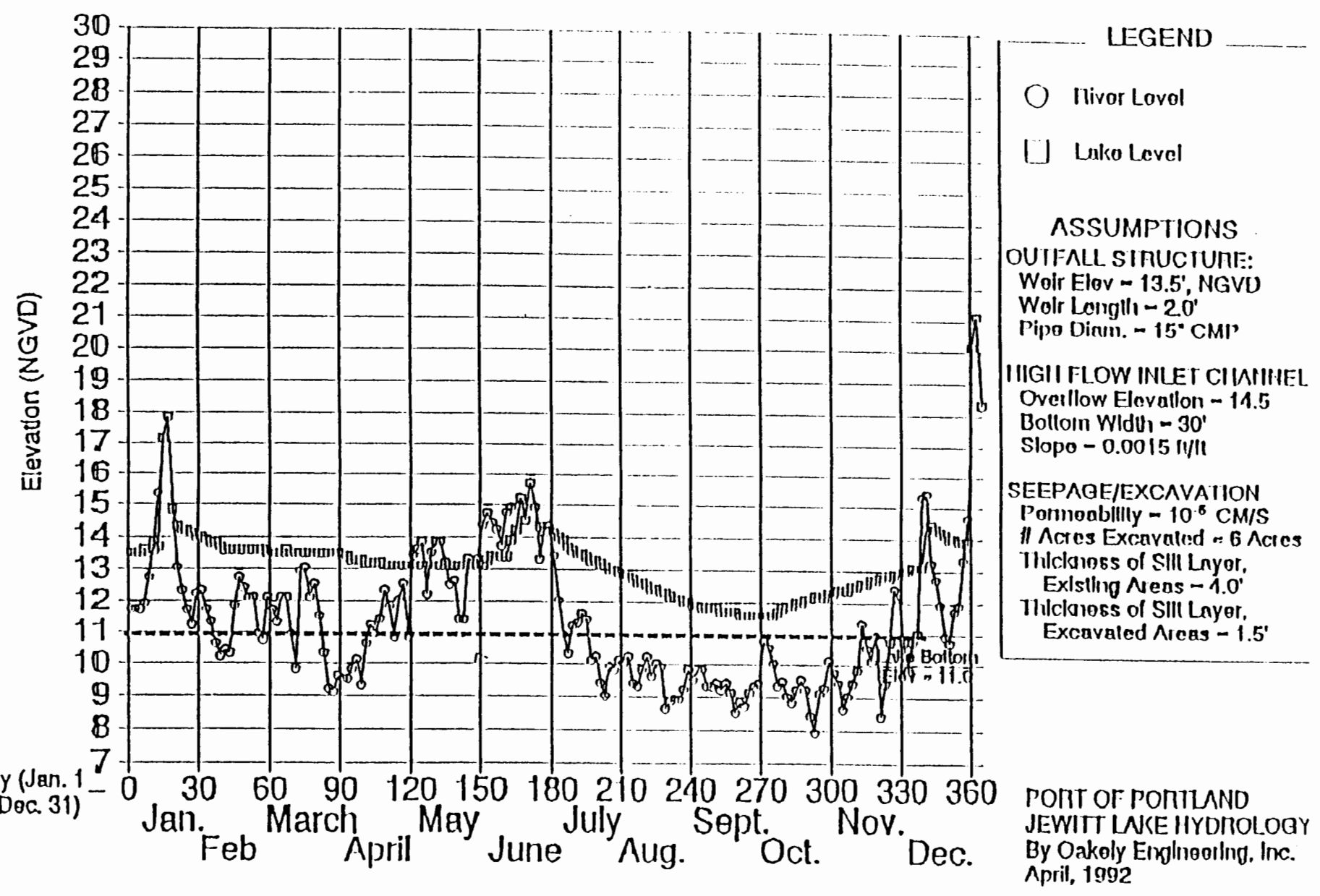


Jewil Lake Hydrnlogic Analysis

Estimated Lake Levels Based on 1981 River Data

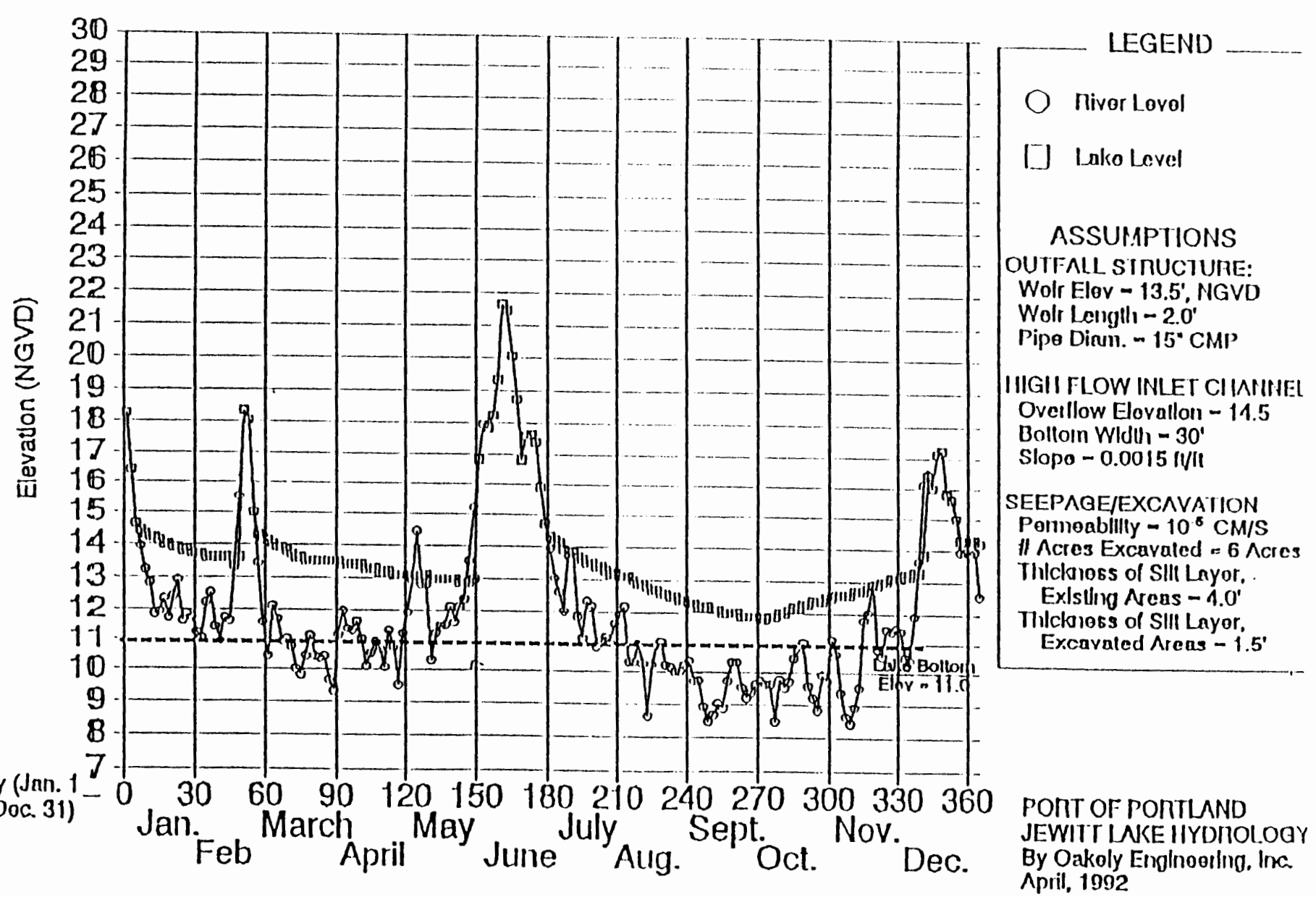


Jewil Lake Hydrologic Analysis

Estimated Lake Levels Based on 1982 River Data

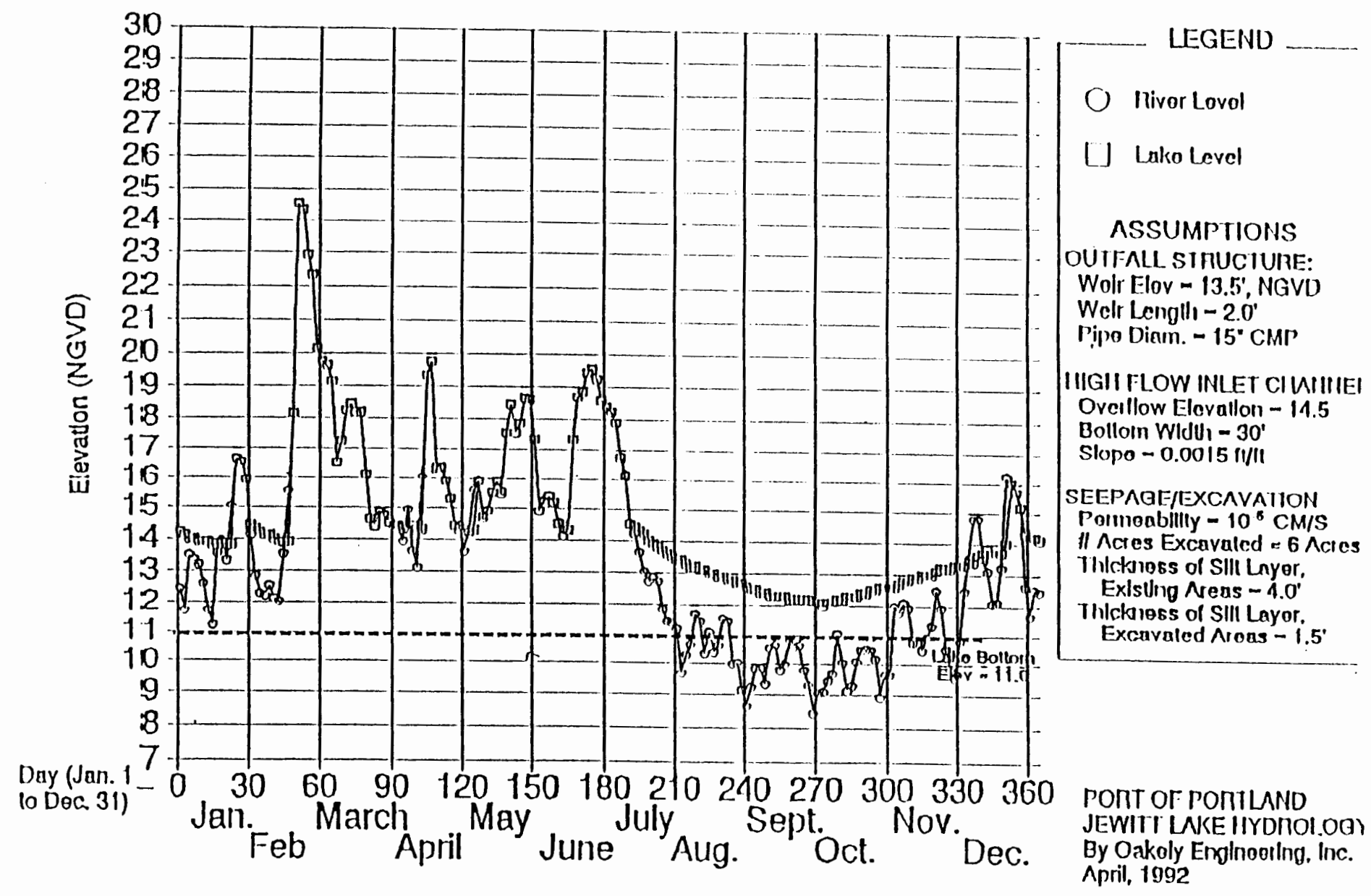


Jewit Lake Hydrologic Analysis

Estimated Lake Levels Based on 1983 River Data

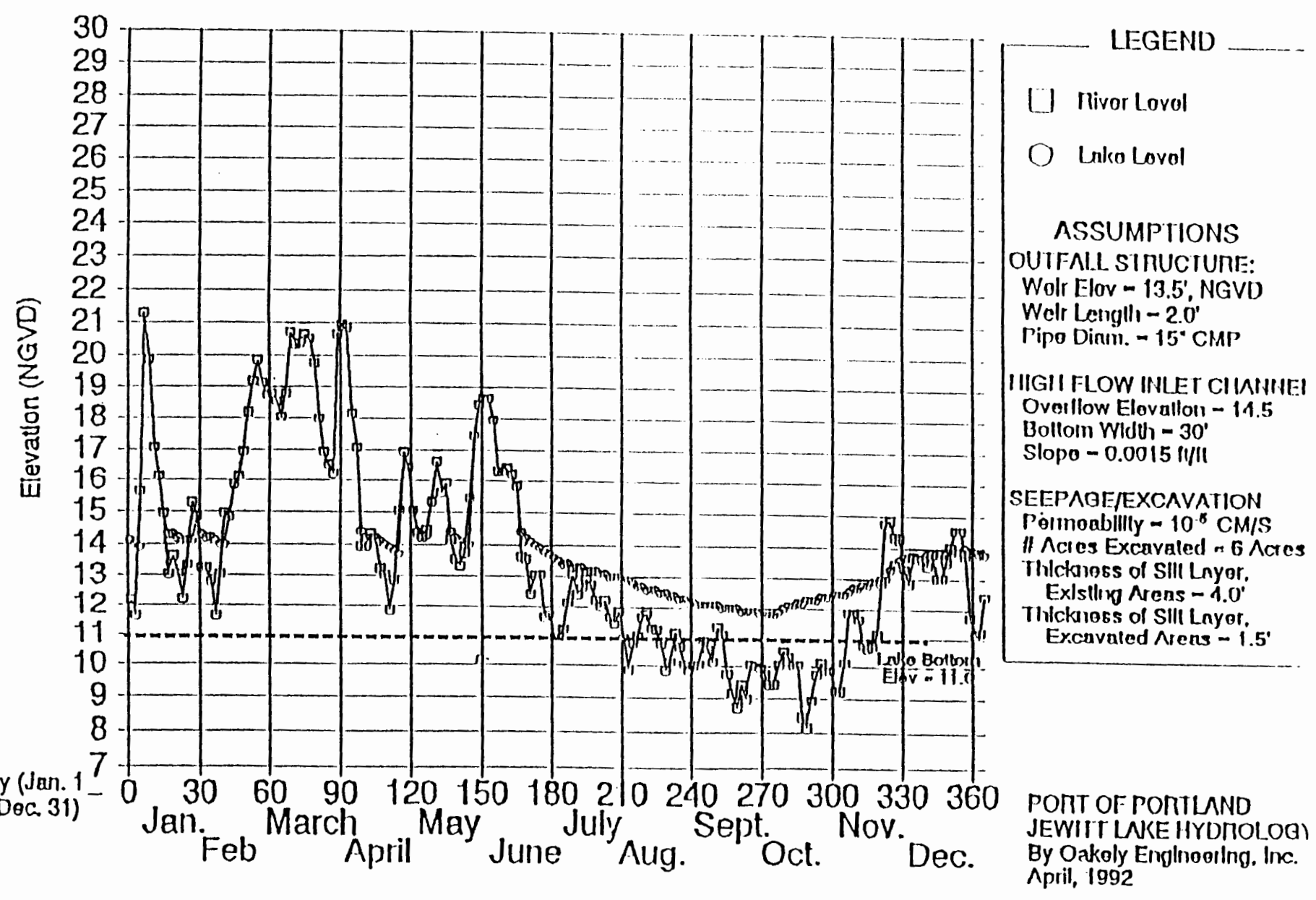


Jewit Lake Hydrologic Analysis

Estimated Lake Levels Based on 1984 River Data

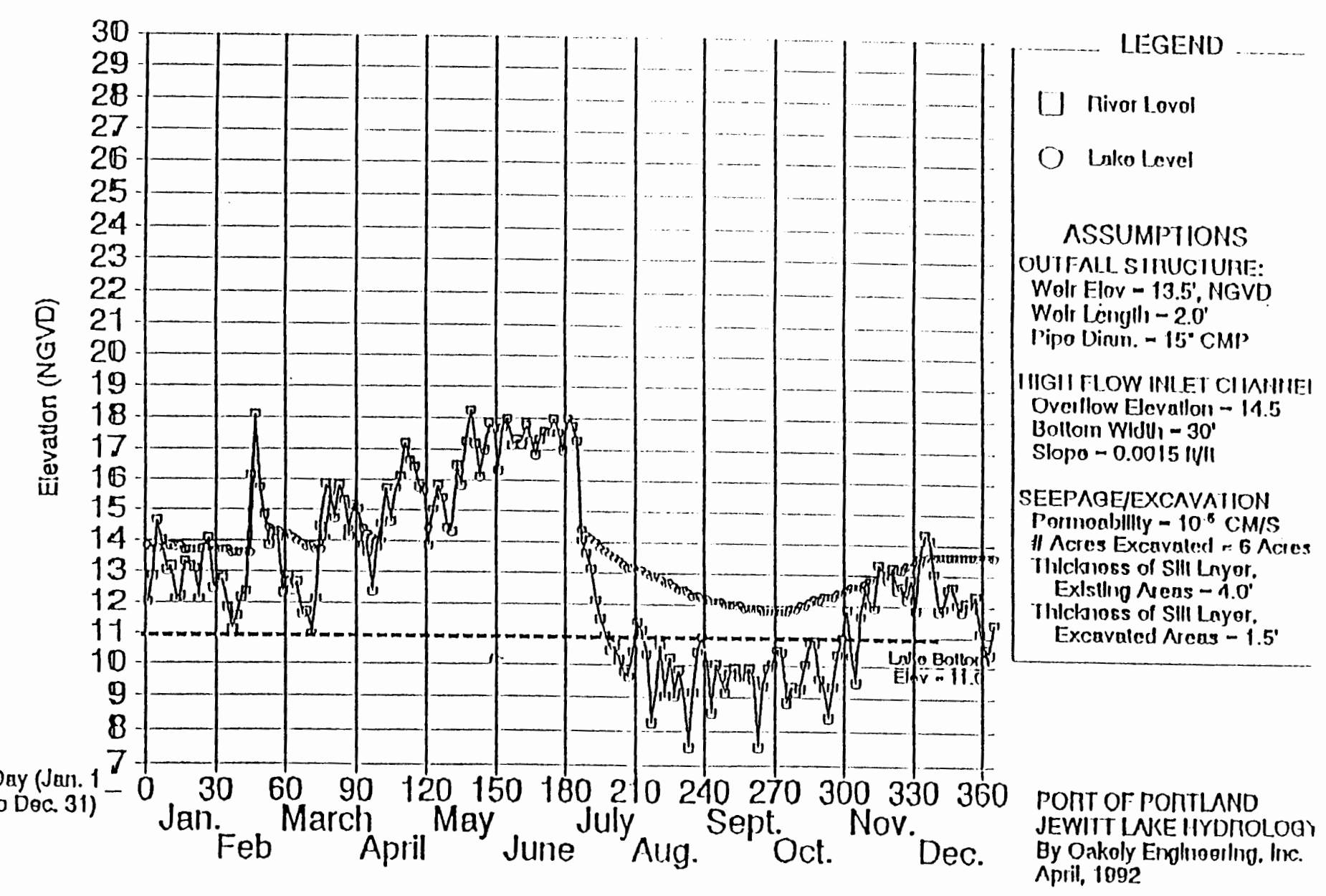


Jewit Lake Hydrologic Analysis

Estimated Lake Levels Based on 1985 River Data

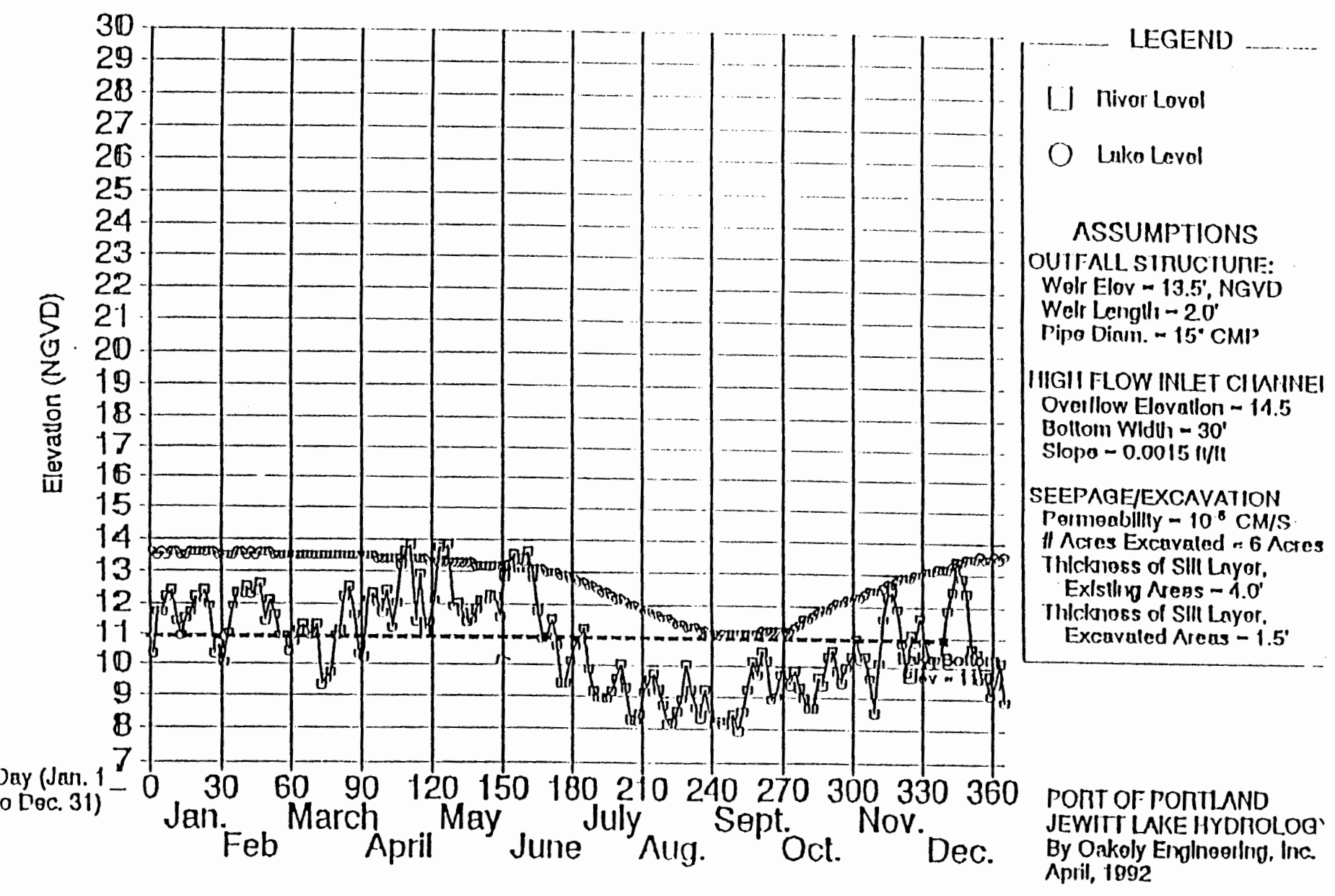


Jewil Lake Hydrologic Analysis

Estimated Lake Levels Based on 1986 River Data

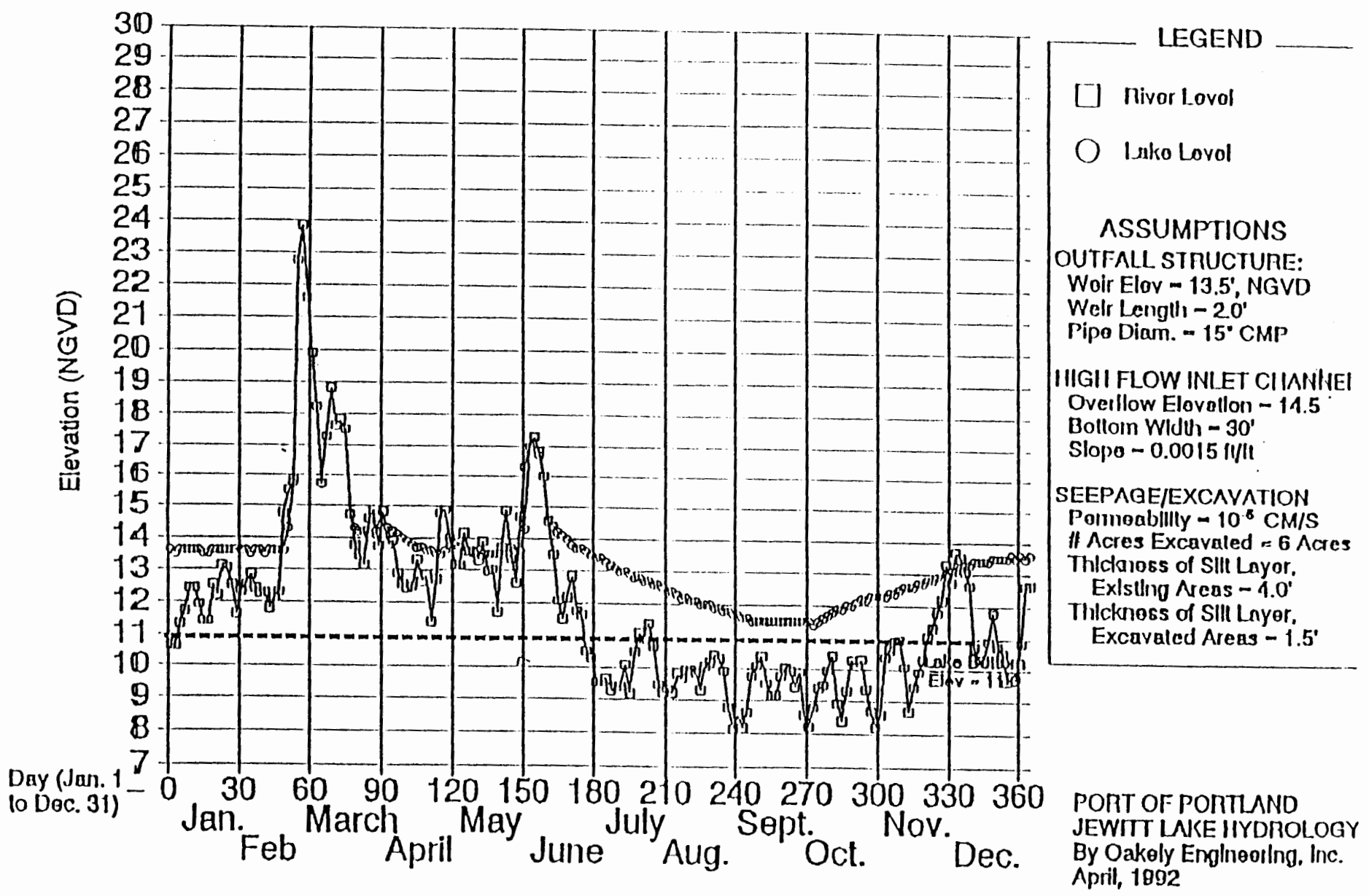


Jewit Lake Hydrologic: Analysis

Estimated Lake Levels Based on 1987 River Data

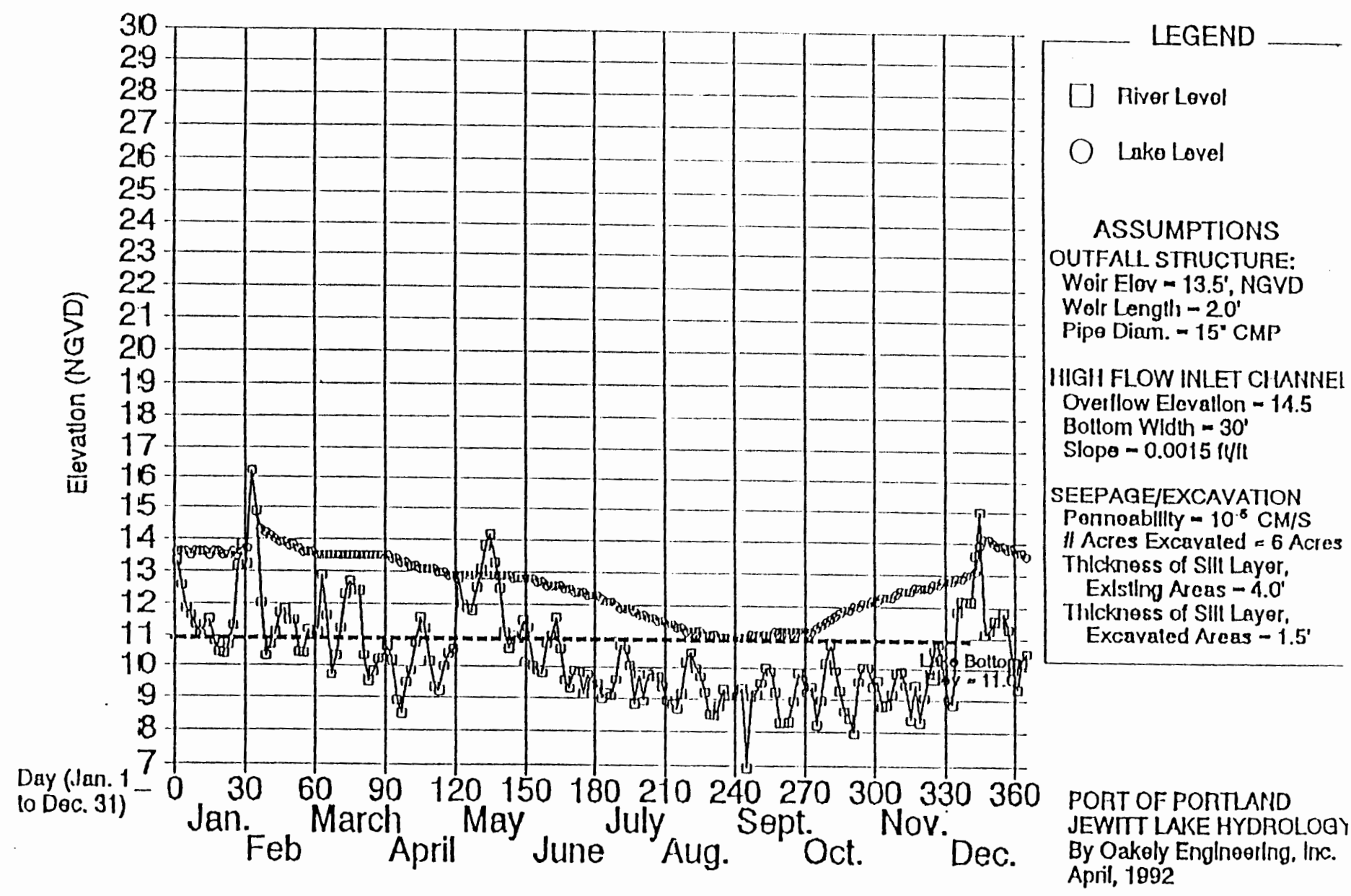


Jewil Lake Hydrologic Analysis

Estimated Lake Levels Based on 1988 River Dala

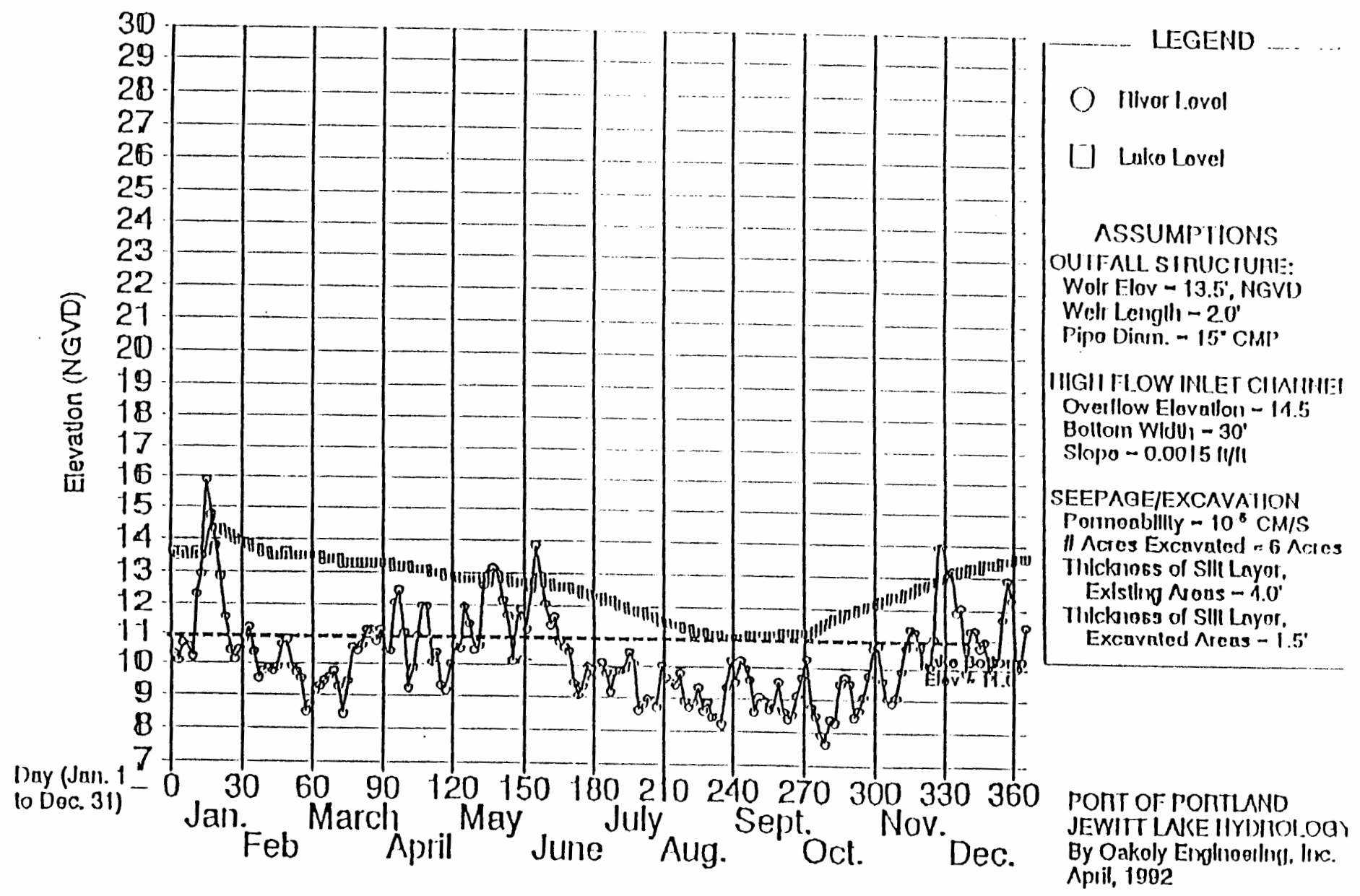


Jewil Lake Hydrologiç Analysis

Estimated Lake Levels Based on 1989 River Dala

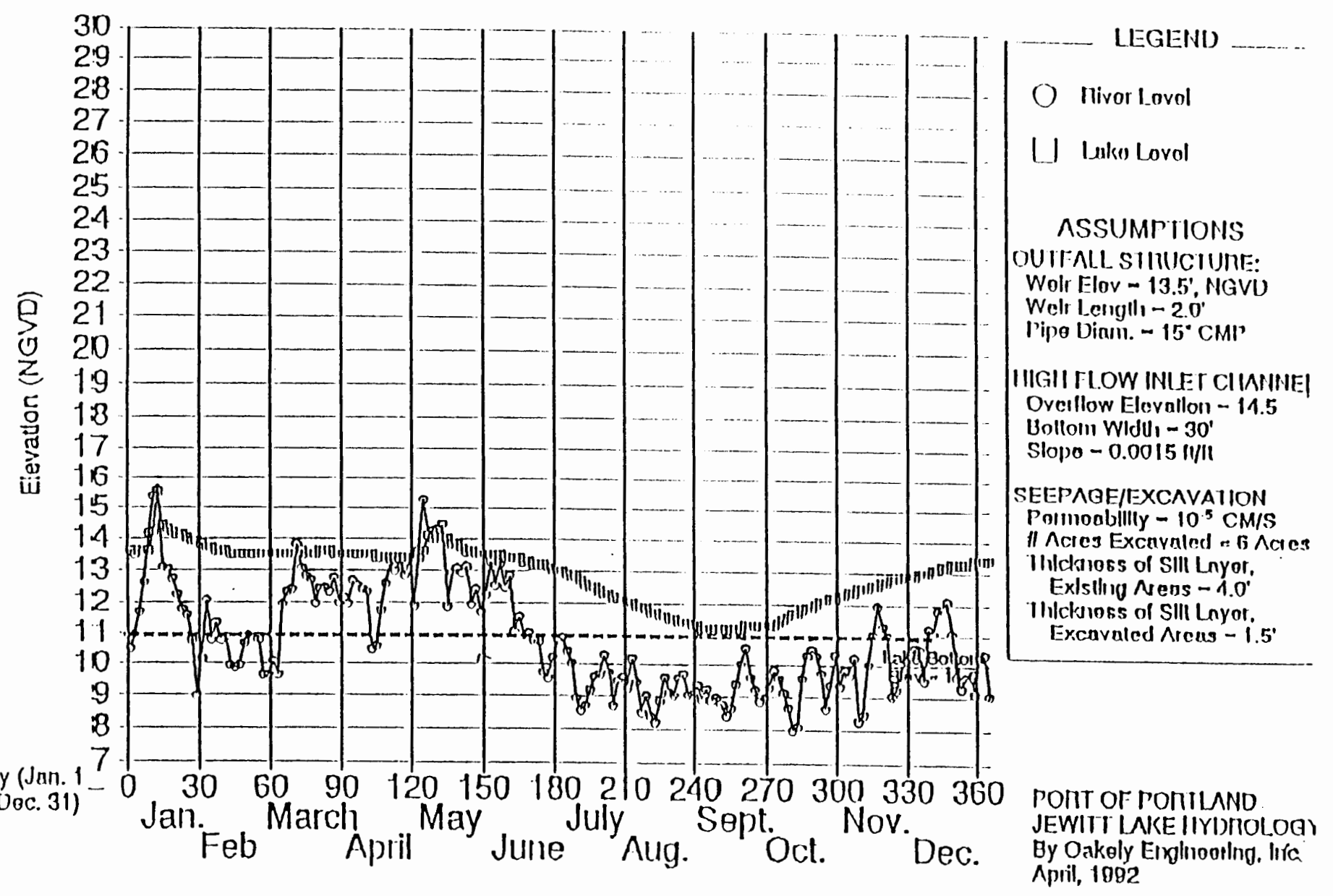




\section{Appendix 2}

Plots of the grain size distribution were made based on hydrometer readings taken at predetermined time intervals. The hydrometer method of Day (1965) assumes that a particle will fall to the bottom of a water column in a time that is determined solely by its grain size. The percentages of each size fraction are determined by subtracting the mass of sediment present in the water column at each reading from 100 percent of the total mass of the sample. Each reading is shown with an asterisk in the graphs of particle size distribution.

In the particle size distribution graphs, sand has grain sizes larger than $0.0625 \mathrm{~mm}$. Silts have grain sizes between $0.004 \mathrm{~mm}$ and $0.0625 \mathrm{~mm}$. Clay is represented by the particles finer than $0.004 \mathrm{~mm}$ that fell out of the water column. The remaining particles in the water column are colloidal and organic material.

One hour is required for silt to begin settling out of a water column. Twenty four hours are required for clay to begin settling out of a water column (Day, 1965).

Using the United Soil Classification System (Soil Survey Staff, 1992), samples 1 through 14 are silt loams. Sample 15 is a loam. 
Sample 1

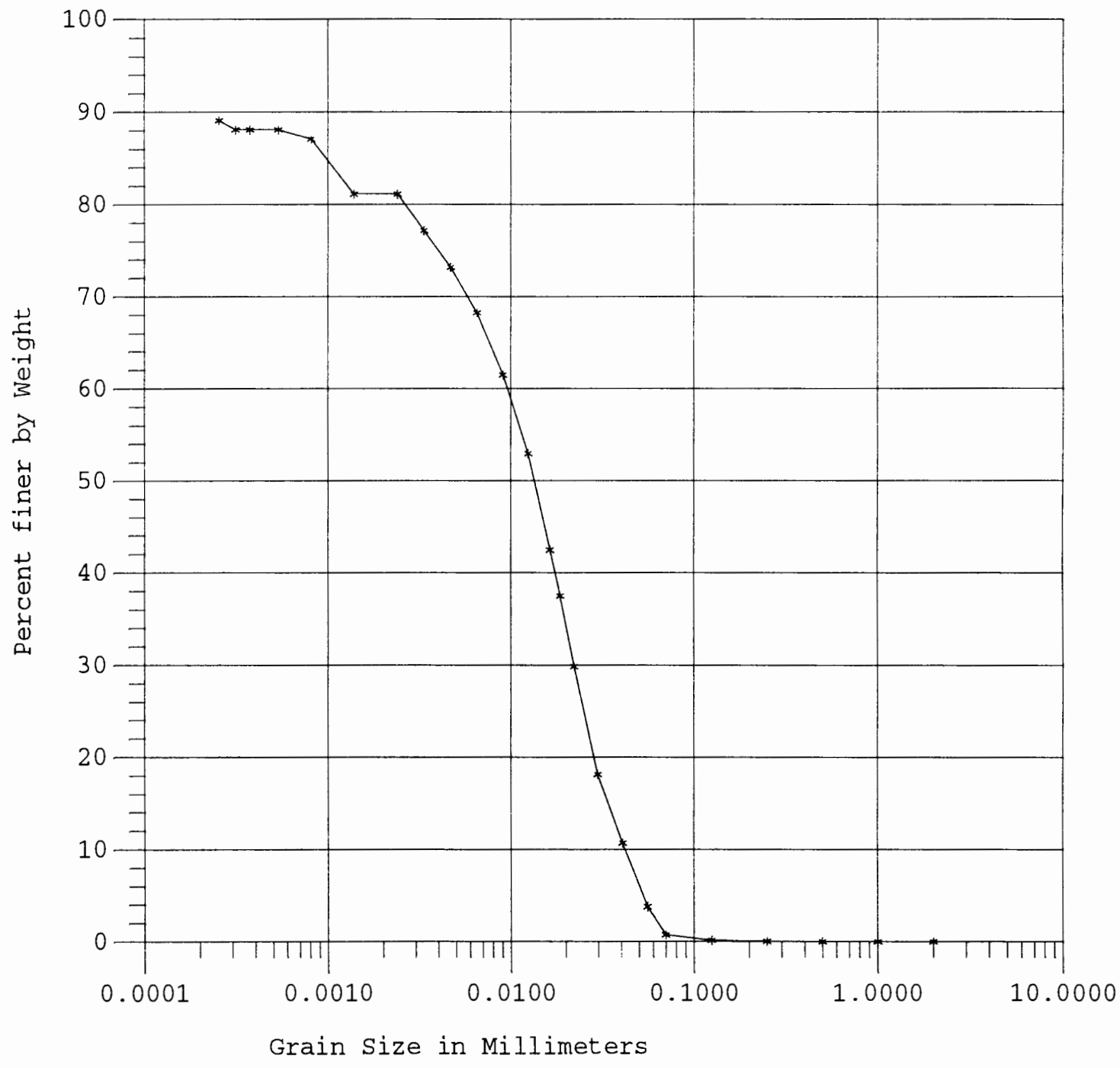


Sample 2

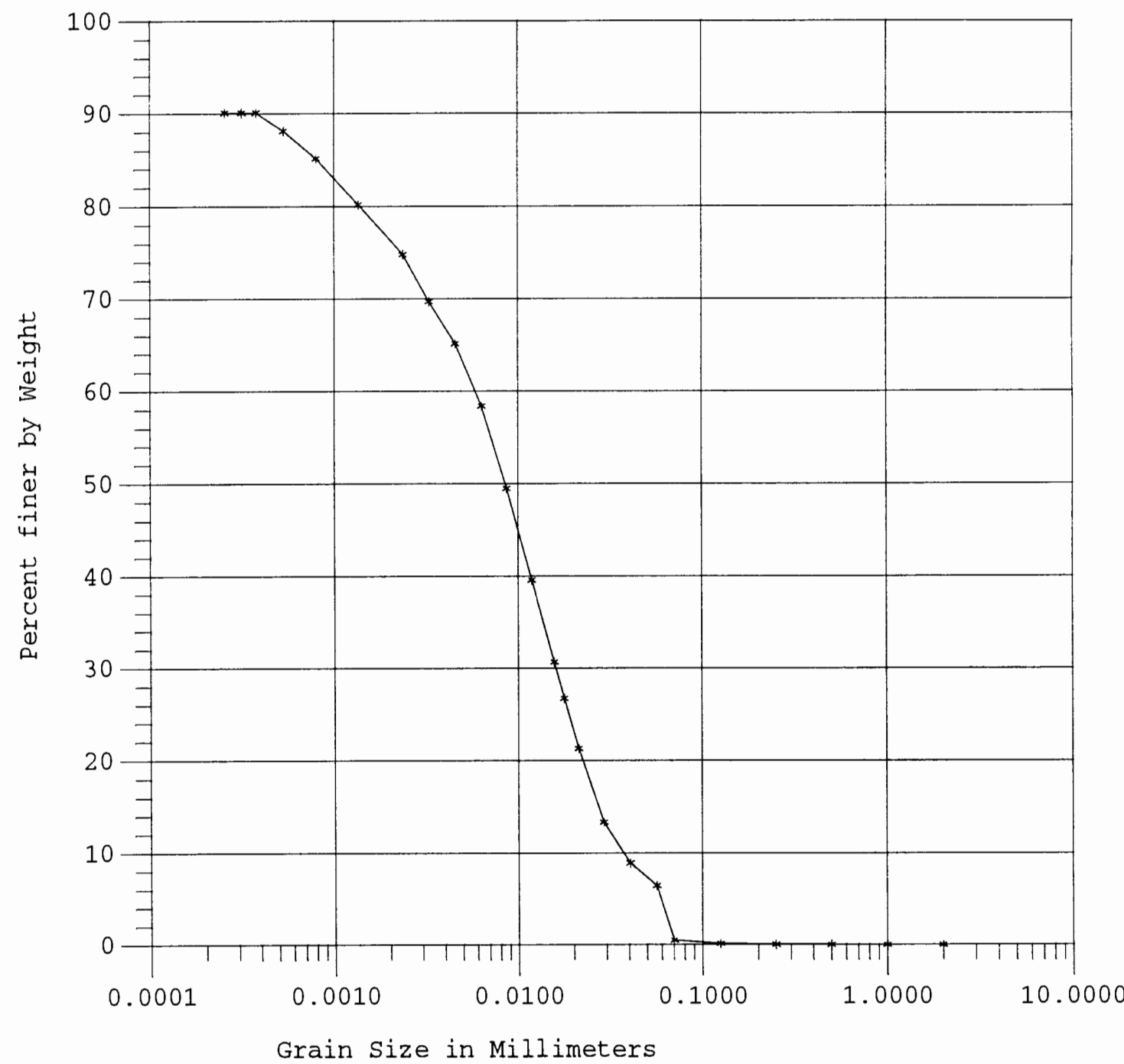


Sample 3

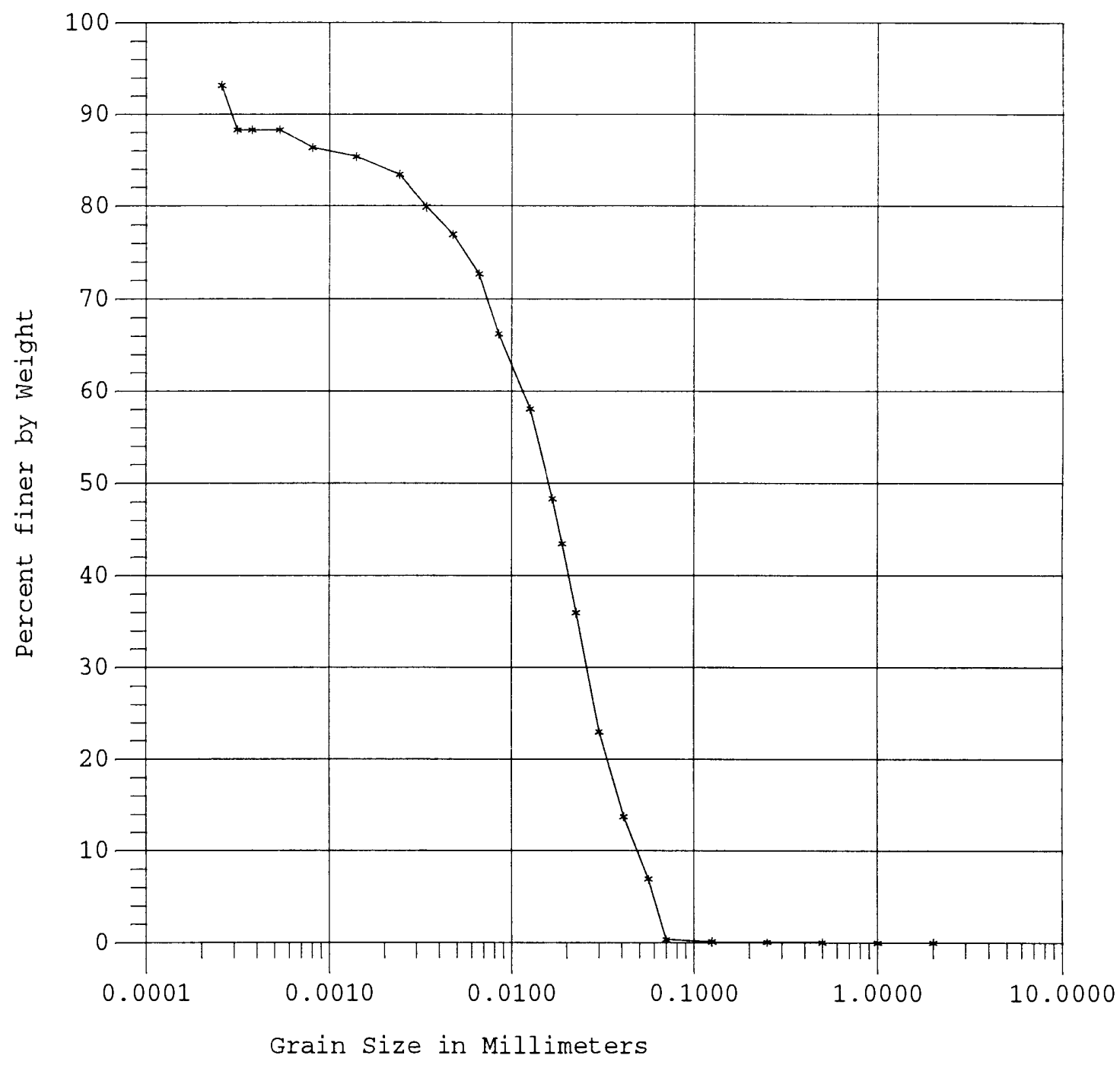


Sample 4

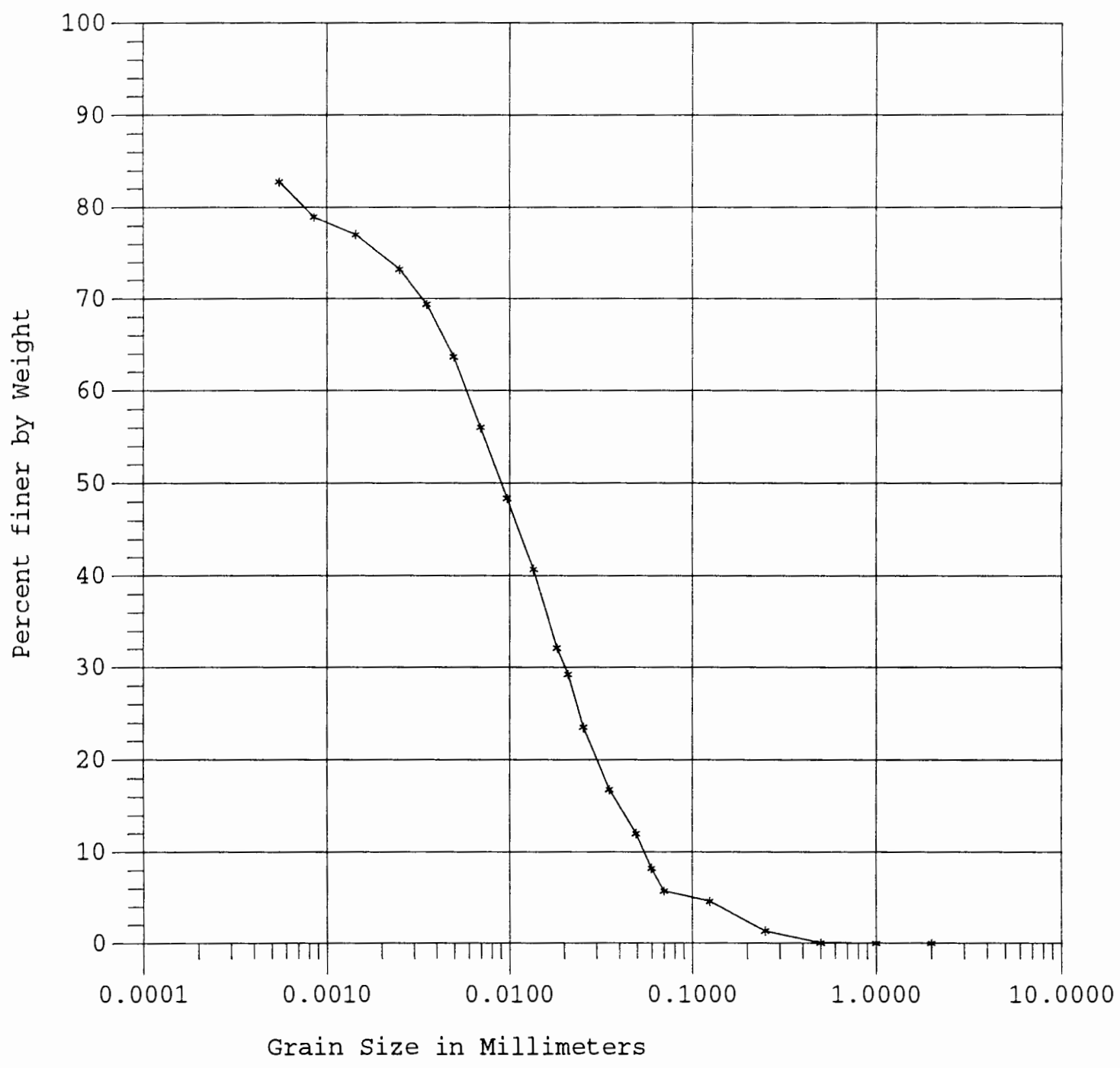


Sample 5

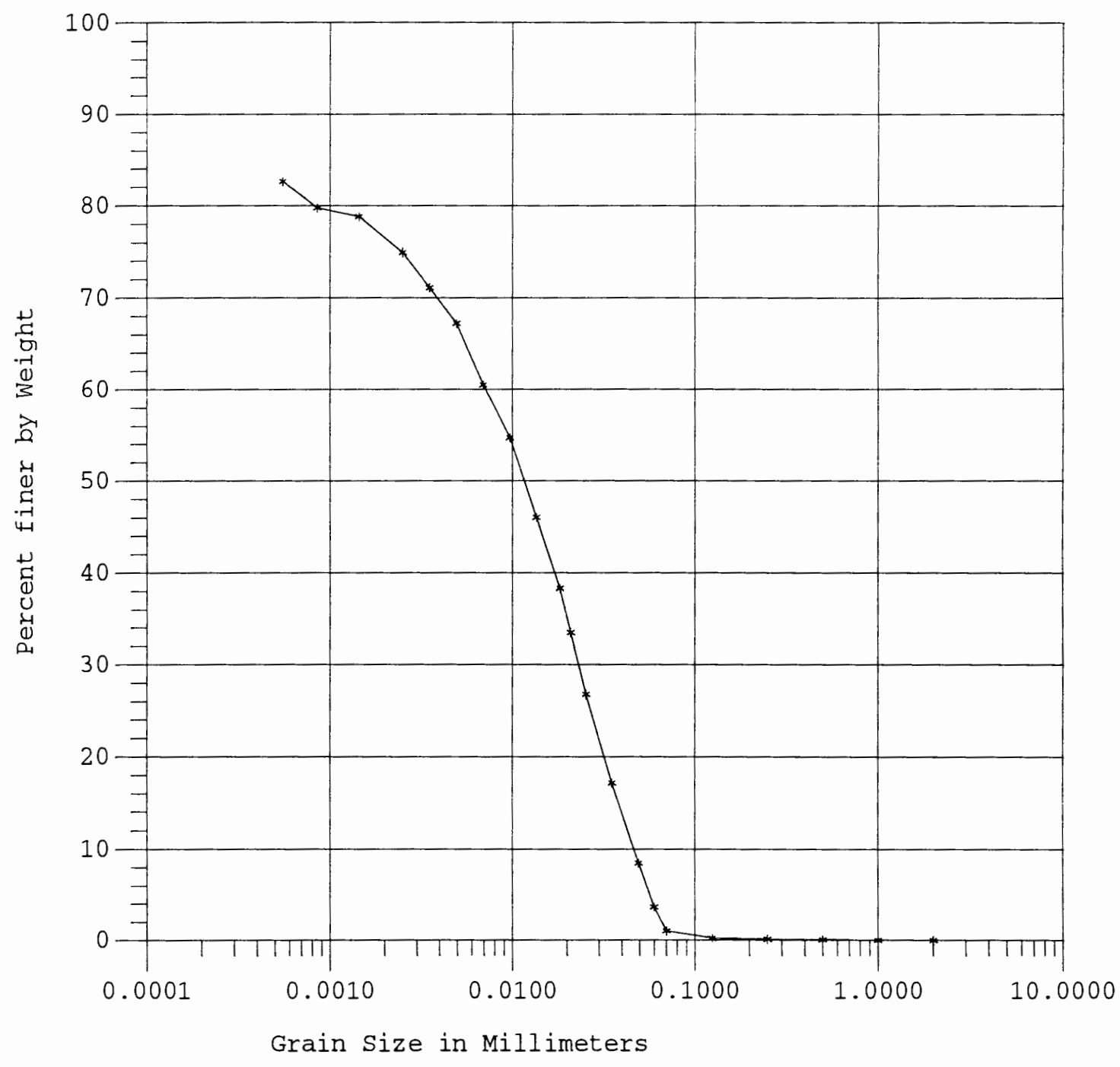


Sample 6

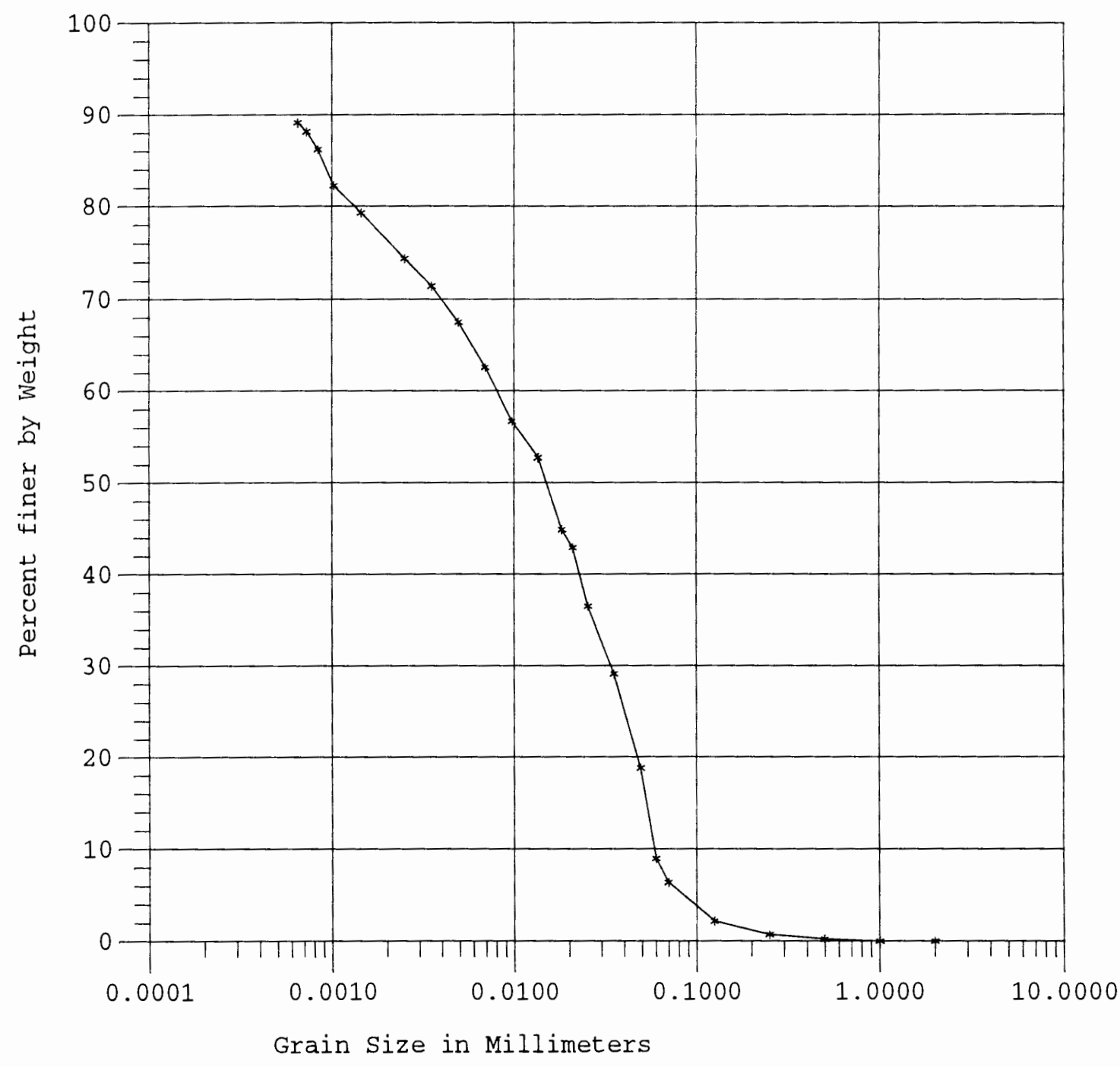


Sample 7

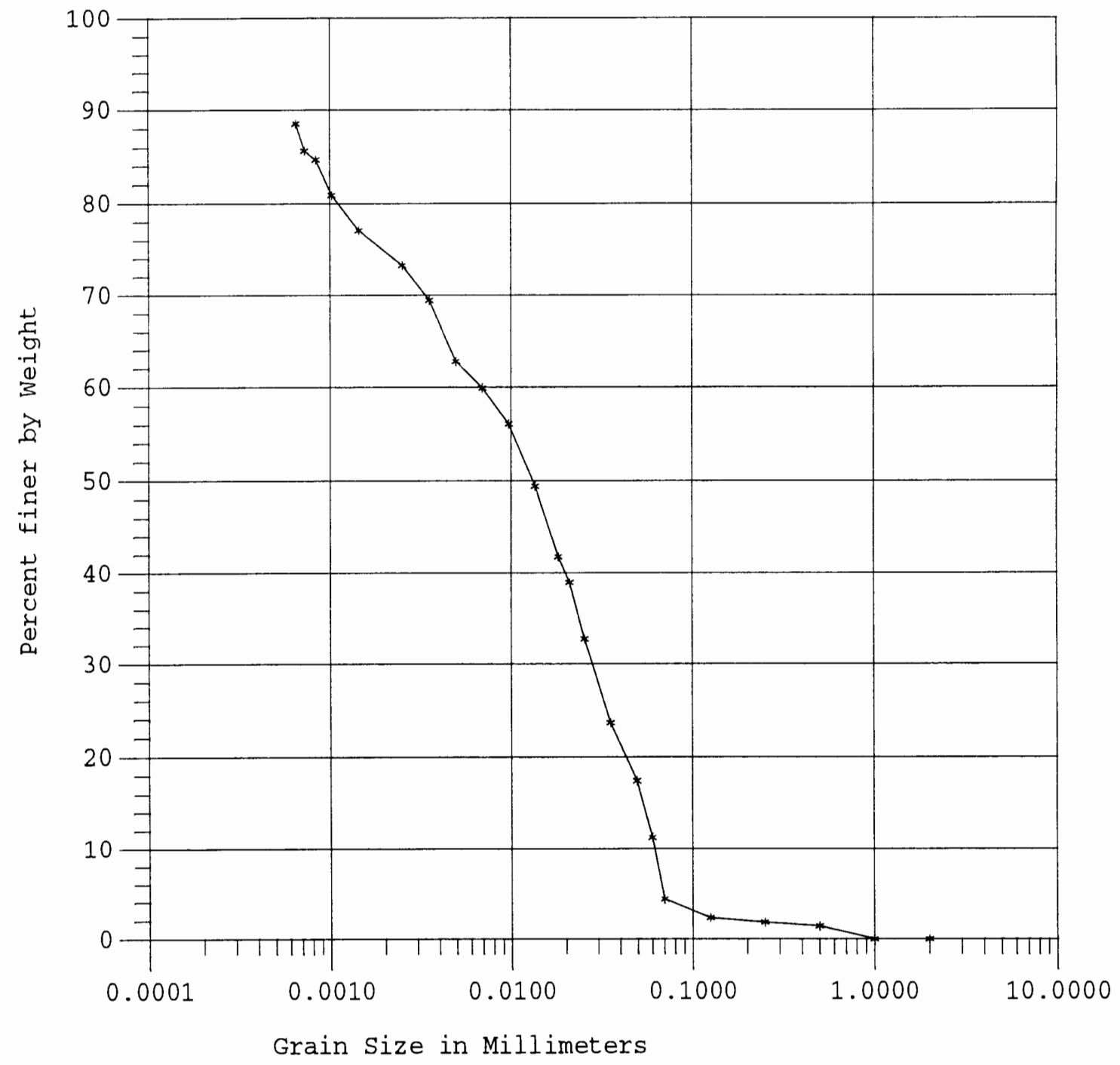


Sample 8

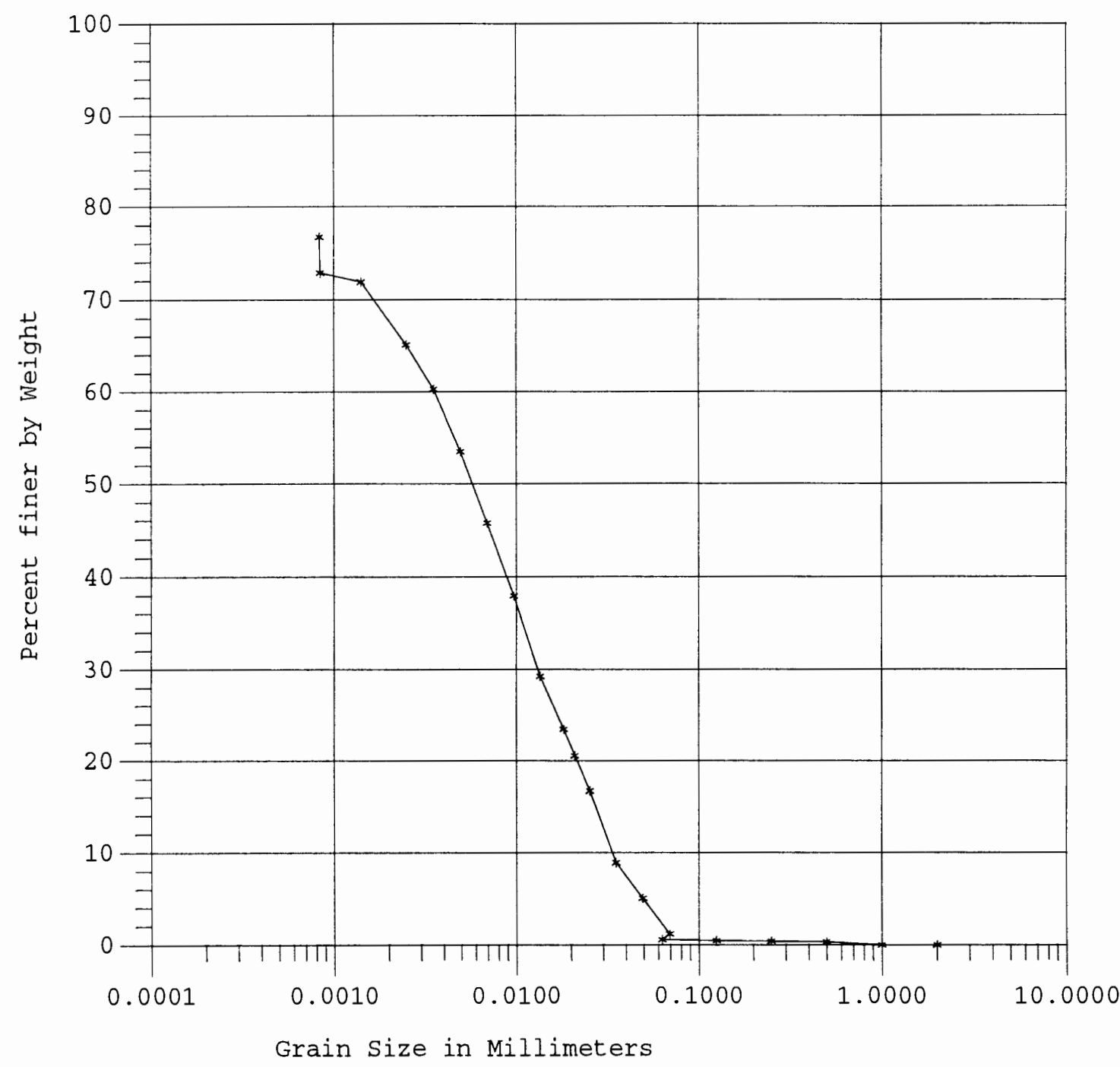


Sample 9

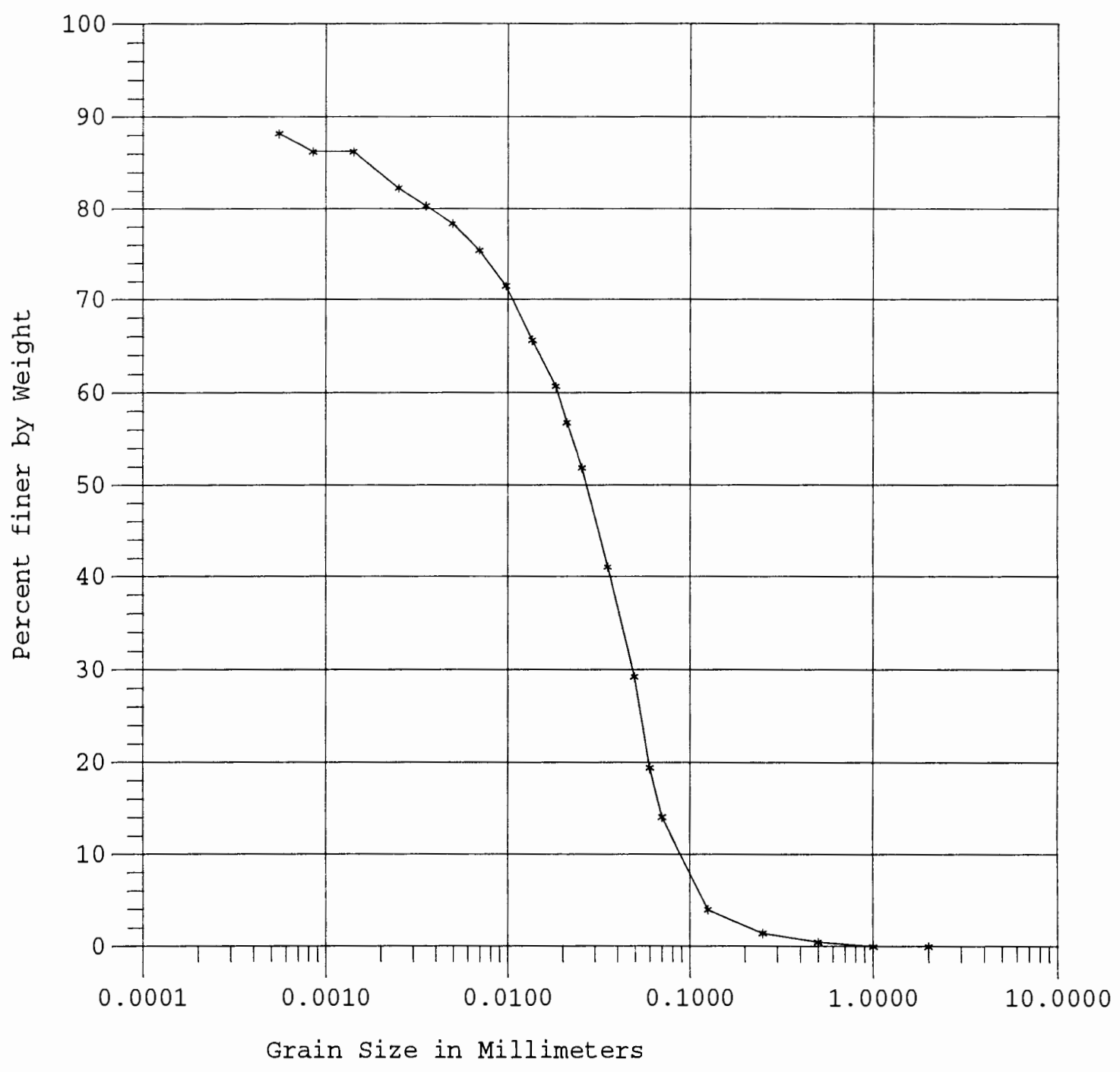


Sample 10

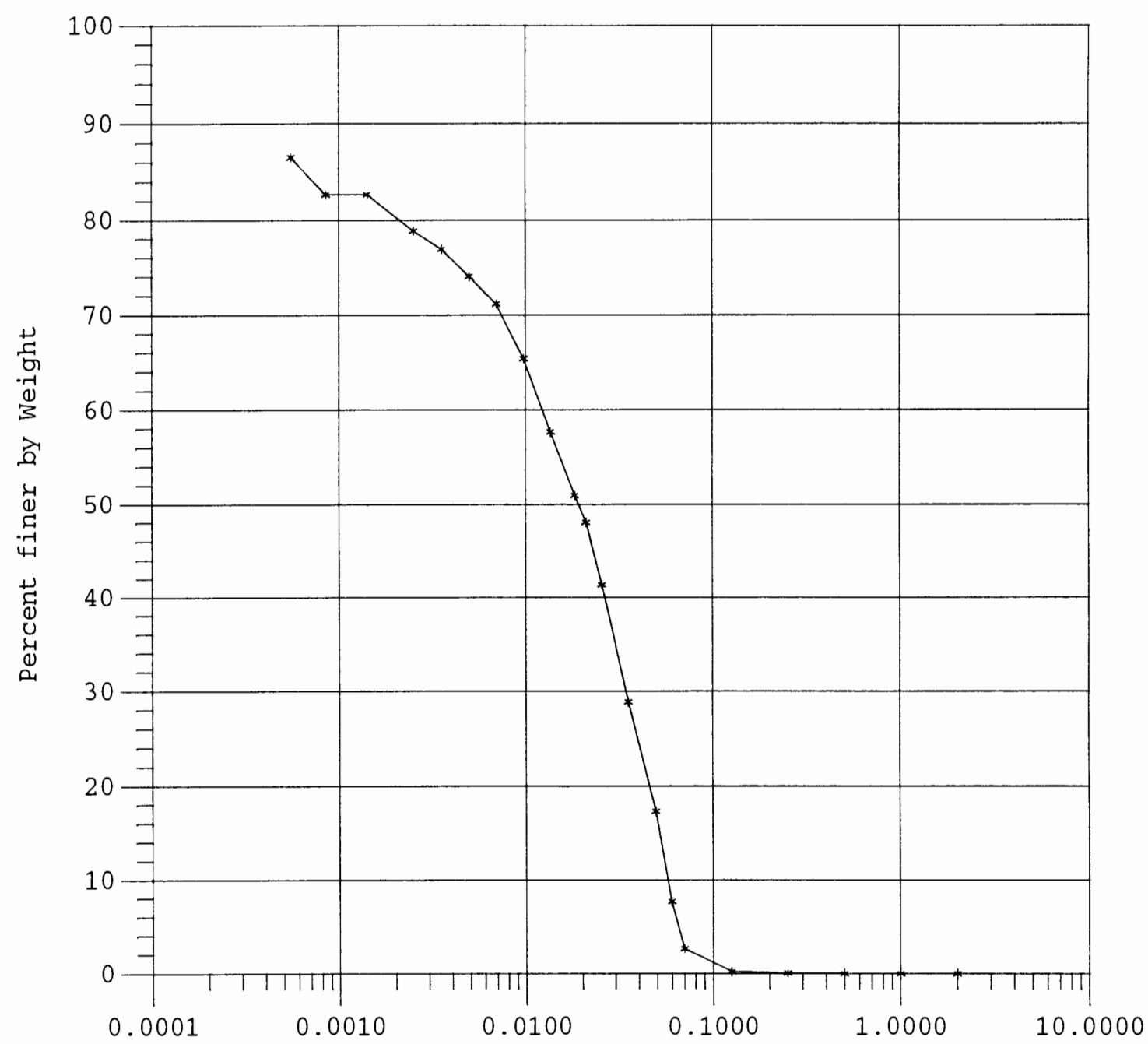

Grain Size in Millimeters 
Sample 11

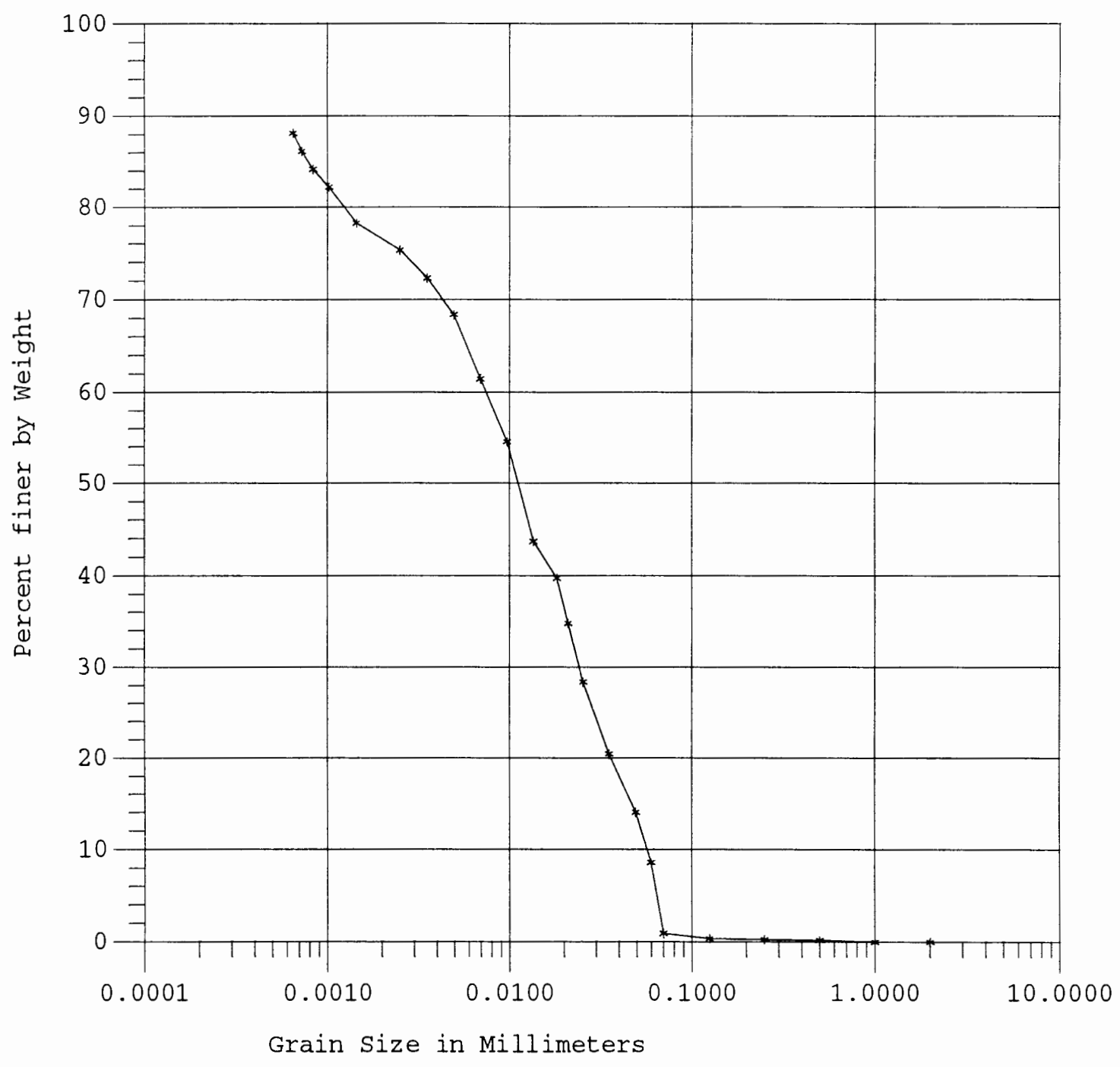


Sample 12

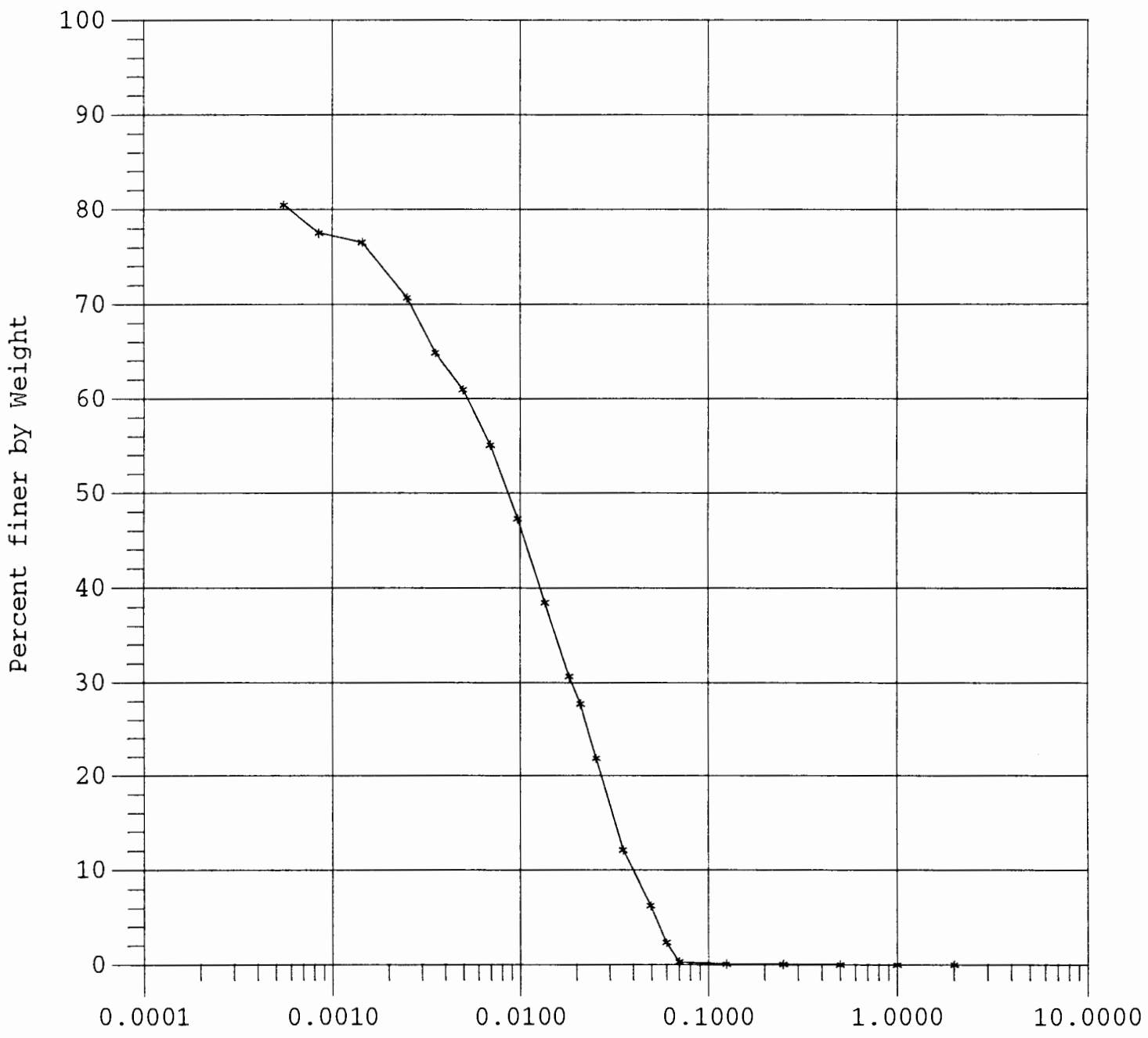

Grain Size in Millimeters 
Sample 13

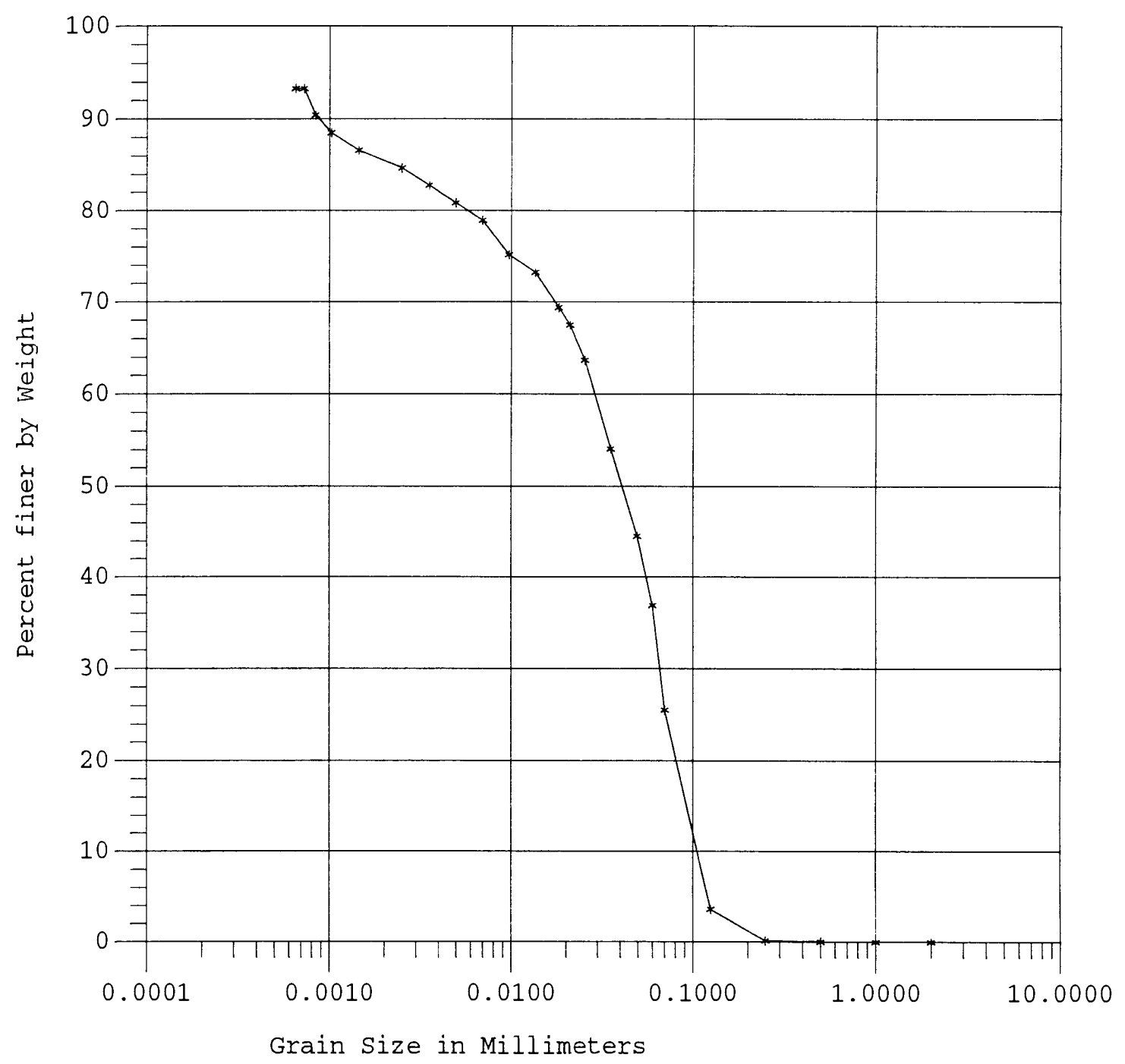


Sample 14

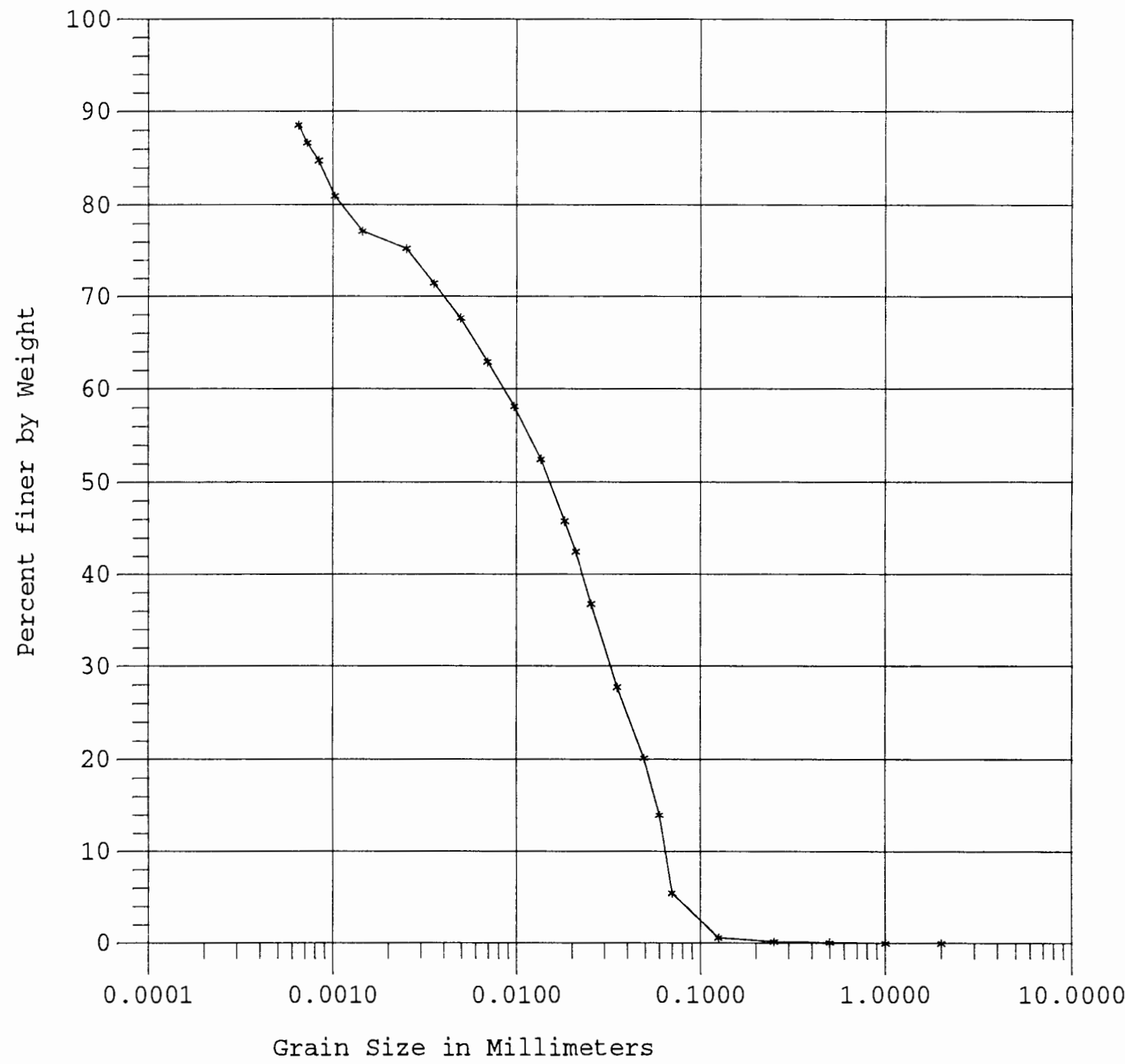


Sample 15

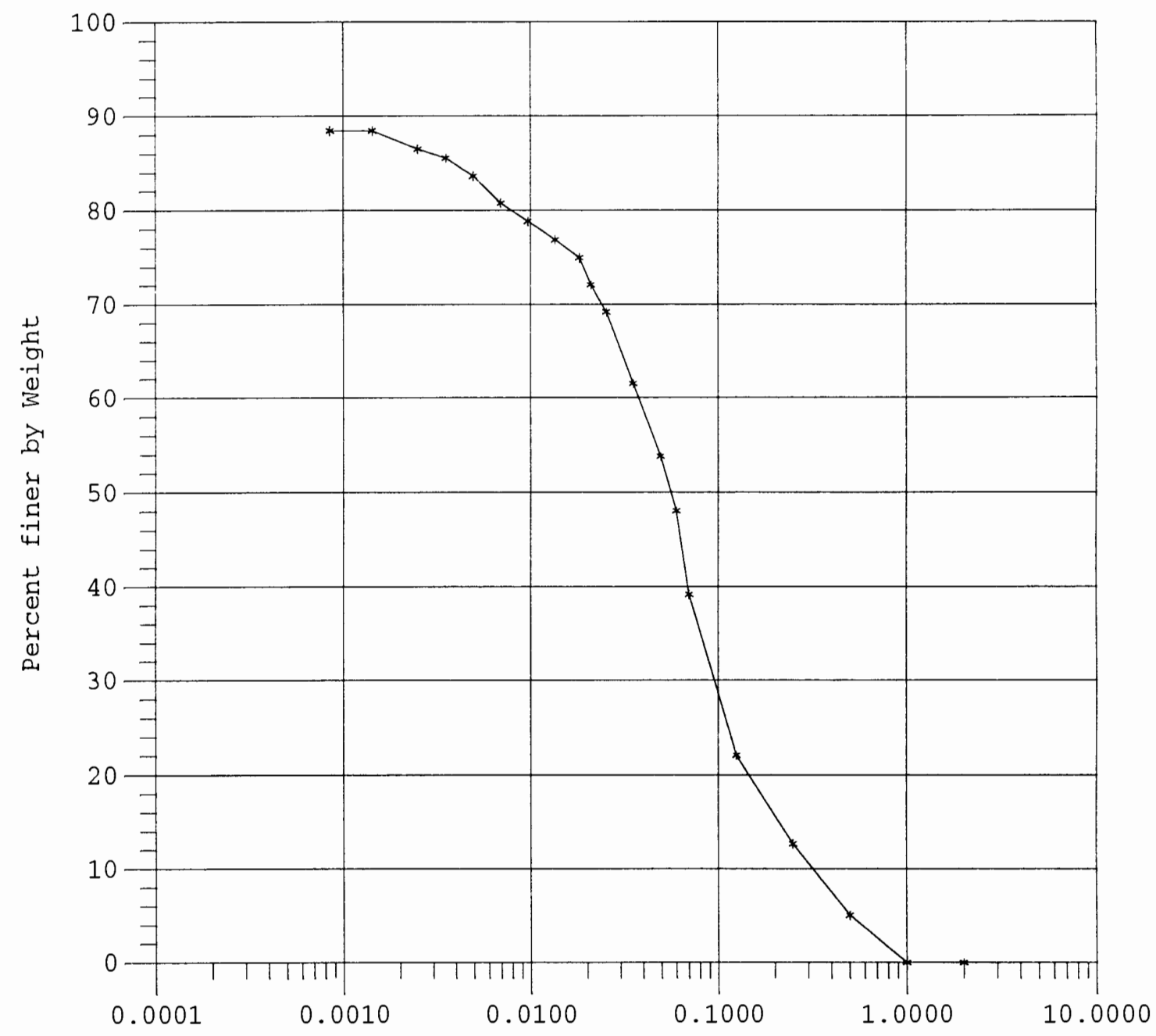

Grain Size in Millimeters 


\section{Appendix 3}

Appendix 3 contains the seismic refraction receiver time data at stations G-1, G-5, G-9, G-13, and G-14. A change in slope in the reciever distance versus receiver time graphs indicates that a change in seismic wave velocity has occurred. The change in slope in the graph likely differentiates saturated strata from unsaturated strata. Depths to the water table are given in Table 6 . The depth at which the seismic wave velocity contrast occurs was determined by the formula

$$
z=x^{\prime} / 2 \star\left[\left(V_{2}-V_{1}\right) /\left(V_{2}+V_{1}\right)\right]^{1 / 2}
$$

where $\mathrm{z}$ is the depth to the seismic wave velocity contrast, $x^{\prime}$ is the crossover distance, $V_{1}$ is the seismic wave velocity in the unsaturated sediment, and $V_{2}$ is the seismic wave velocity in the saturated sediment. The crossover distance value is taken from the time versus reciever distance plots. The crossover distance is extrapolated to the $\mathrm{x}$-axis (receiver distance) from the position on the graph where the best fit lines for $V_{1}$ and $\mathrm{V}_{2}$ intersect. 
STATION G-1 EAST

G-1 EAST

G-1 EAST

G-1 WEST
RECIEVER 1

\subsection{0}

0.007

0.011

0.016

0.020

0.022

0.025

0.029

0.030

0.031

0.032

0.033

2

0.000

0.012

0.022

0.026

0.031

0.032

0.034

0.035

0.036

0.037

0.039

0.040

5

0.000

0.035

0.044

0.048

0.051

0.054

0.056

0.059

0.063

0.000

0.005

0.010

0.018

0.020

0.024

0.027

0.026

0.031

0.032
REVERSE (SEC)

0.045

0.044

0.043

0.042

0.041

0.038

0.036

0.032

0.027

0.018

0.012

0.000

0.040

0.039

0.037

0.036

0.034

0.031

0.029

0.027

0.023

0.020

0.010

0.000

0.056

0.054

0.051

0.049

0.047

0.044

0.040

0.036

0.033

0.024

0.000

0.039

0.038

0.033

0.033

0.030

0.029

0.025

0.027

0.021

0.015 
STATION

G- 1 WEST

G- 1 WEST

G- 5 WEST

G- 5 WEST
RECIEVER SPACING (M) NORMAL (SEC)

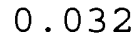

0.033

2

0.000

0.015

0.023

0.033

0.042

0.044

0.049

0.050

0.048

0.045

0.056

5

0.000

0.029

0.046

0.048

0.051

0.057

0.058

0.061

0.063

0.067

0.000

0.015

0.023

0.033

0.042

0.044

0.049

0.050

0.048

0.055

0.056

0.060

0.056

0.053

0.052

0.045

0.043

0.035

0.028

0.000

0.051

0.048

0.047

0.044

0.043

0.040

0.036

0.031

0.009

0.000
0.000

0.029

0.046

0.048

0.051

0.053

0.057
0.060

0.056

0.053

0.052 
G- 9

G- 9

G-9

G-13
1

2

5

1
0.058

0.061

0.063

0.067

0.000

0.007

0.010

0.017

0.017

0.018

0.018

0.021

0.021

0.021

0.022

0.023

0.000

0.011

0.016

0.020

0.022

0.023

0.023

0.025

0.025

0.025

0.025

0.026

0.000

0.020

0.021

0.025

0.027

0.031

0.034

0.036

0.039

0.043

0.044

0.050

0.000

0.008

0.020
0.045

0.043

0.035

0.028

0.000

0.023

0.023

0.021

0.020

0.020

0.019

0.018

0.017

0.014

0.010

0.002

0.000

0.030

0.028

0.027

0.028

0.027

0.026

0.024

0.022

0.020

0.017

0.008

0.000

0.042

0.041

0.036

0.031

0.029

0.027

0.021

0.019

0.015

0.000

0.047

0.043

0.041

0.037 
STATION RECIEVER SPACING (M) NORMAL (SEC) REVERSE(SEC)

G-13

G-13

G- 14
RECIEVER SPACING (M) NORMAL (SEC)

0.027

0.031

0.036

0.040

0.044

0.046

0.048

2

0.000

0.018

0.023

0.038

0.045

0.046

0.046

0.047

0.051

0.051

0.053

0.000

0.025

0.039

0.049

0.051

0.054

0.057

0.060

0.061

0.062

0.065

0.068

0.000

0.002

0.004

0.006

0.009

0.012

0.015

0.018

0.018

0.018

0.019

0.019
0.035

0.029

0.025

0.021

0.011

0.009

0.000

0.052

0.051

0.046

0.046

0.045

0.044

0.035

0.029

0.021

0.012

0.000

0.071

0.060

0.065

0.060

0.061

0.058

0.054

0.050

0.047

0.042

0.023

0.000

0.021

0.022

0.021

0.020

0.020

0.017

0.015

0.010

0.008

0.008

0.001

0.000 
STATION

G-14
RECIEVER SPACING (M) NORMAL (SEC)

$\mathrm{G}-14$
0.000

0.001

0.010

0.015

0.019

0.019

0.020

0.021

0.021

0.022

0.023

0.023

REVERSE (SEC)

0.027

0.027

0.026

0.024

0.022

0.019

0.019

0.018

0.016

0.013

0.002

0.000

0.000

0.058

0.059

0.054

0.049

0.052

0.050

0.049

0.048

0.038

0.035

0.020

0.000 
G-1 East (5 m spacing)

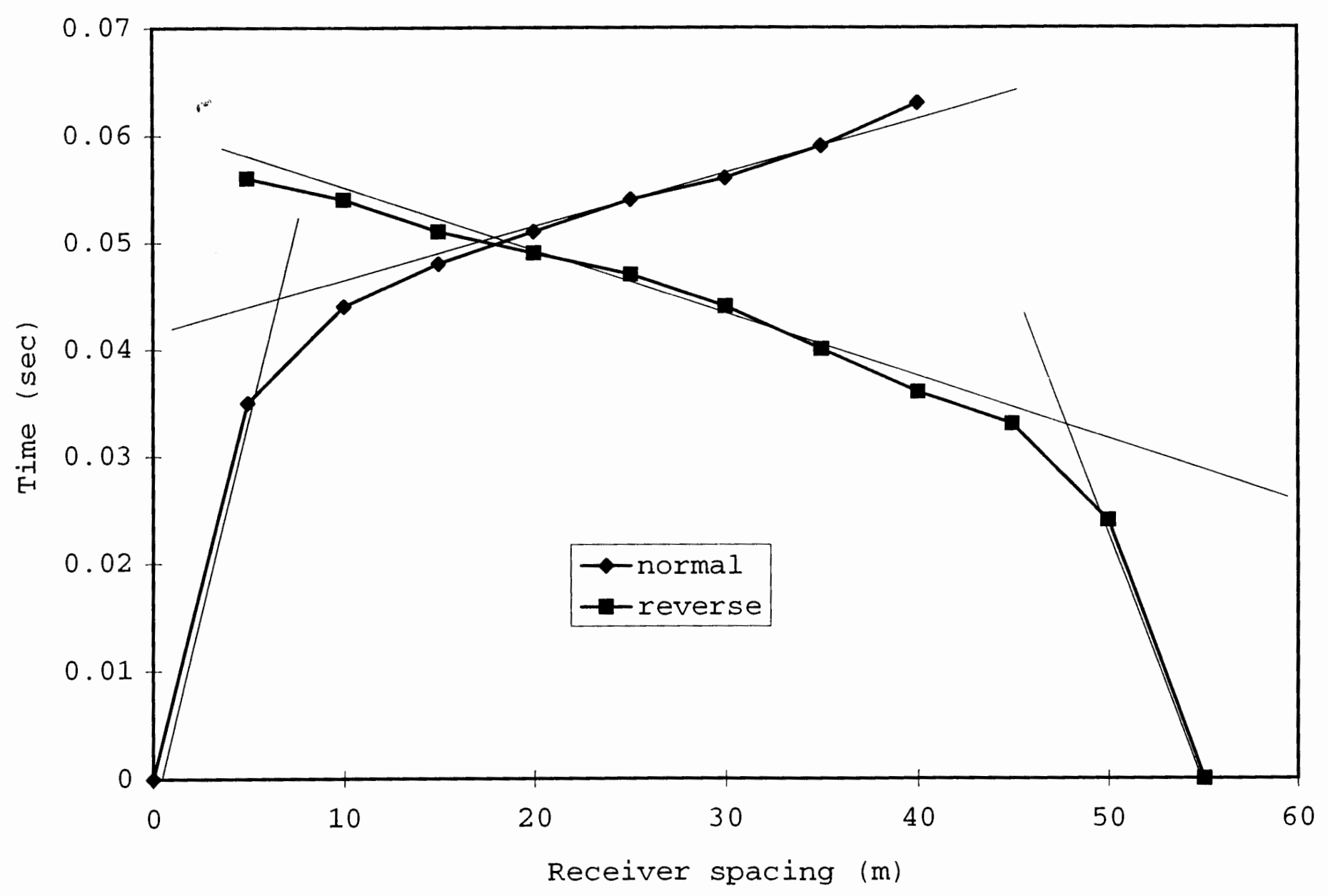


G-5 West ( $5 \mathrm{~m}$ spacing)

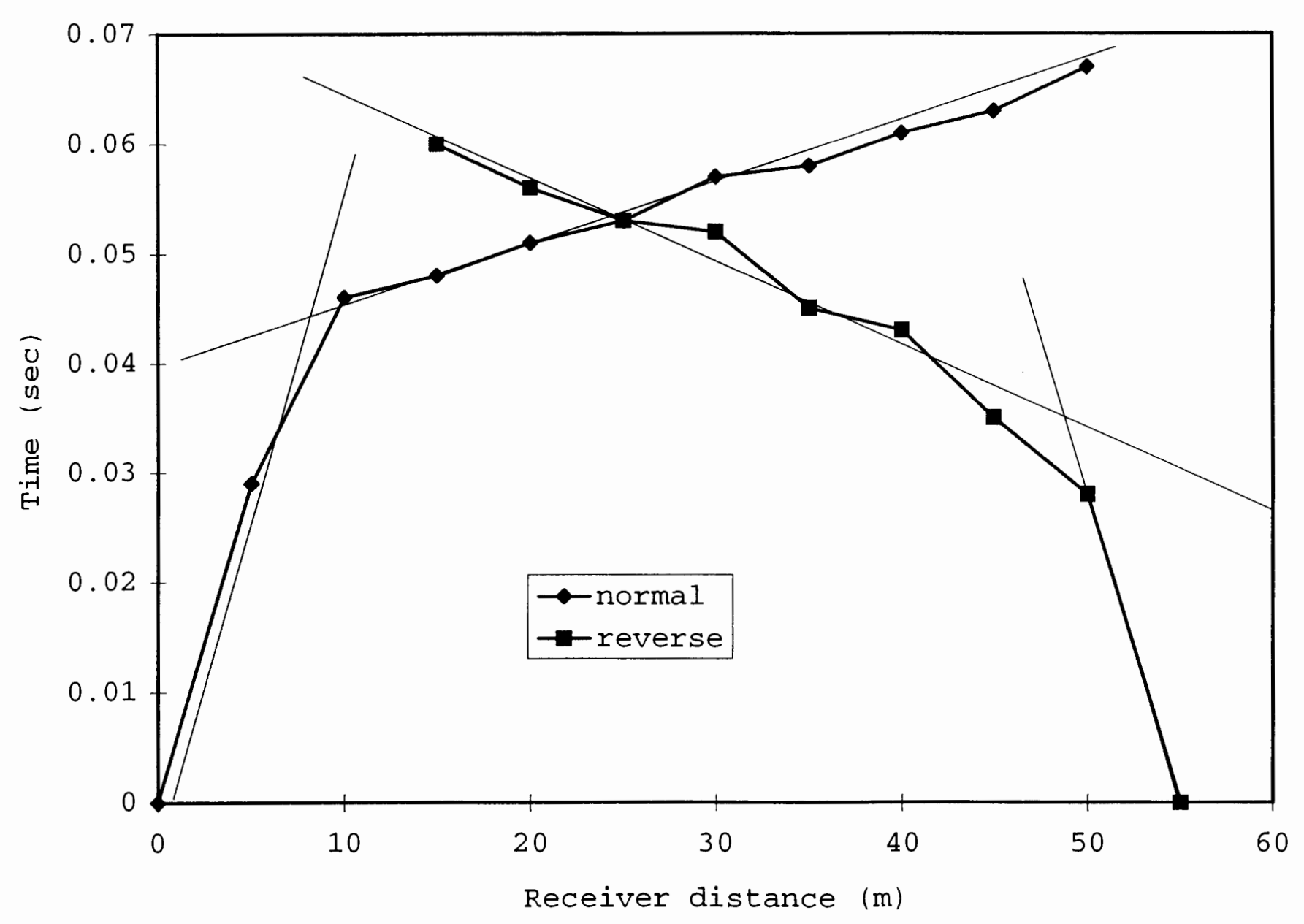


G-9 (5 m spacing)

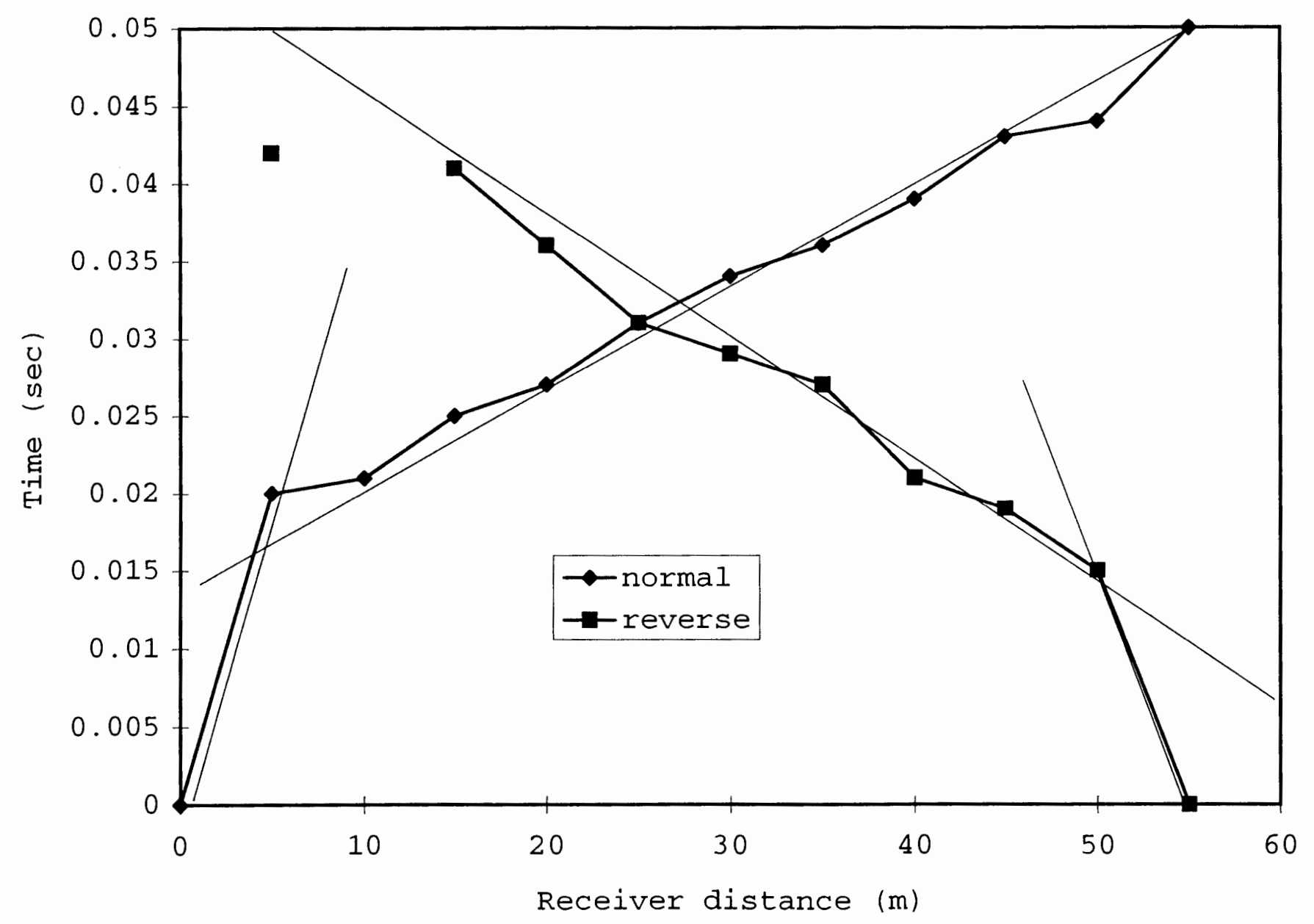




\section{G-13 (2 $\mathrm{m}$ spacing)}

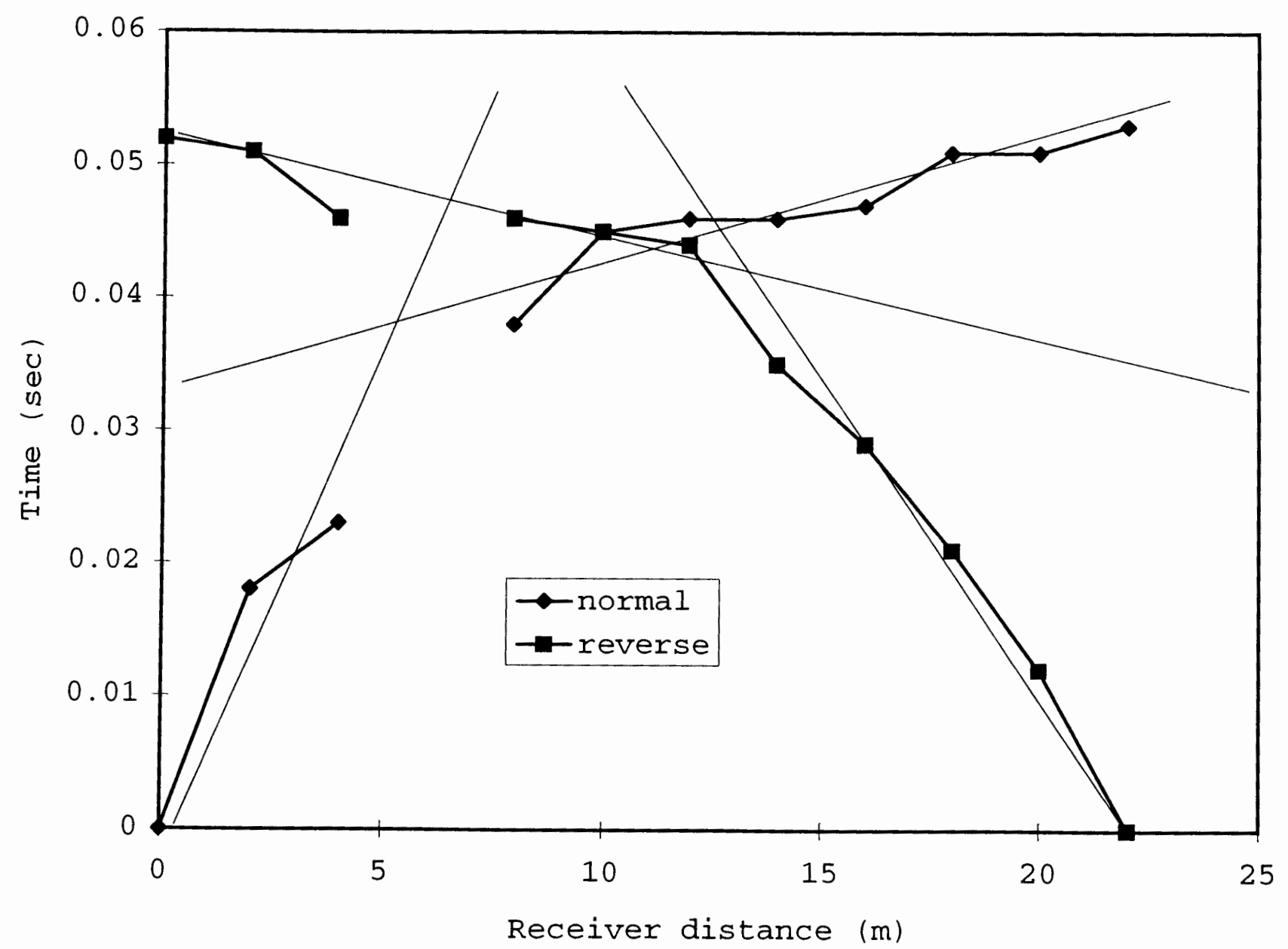


G-14 (2 m spacing)

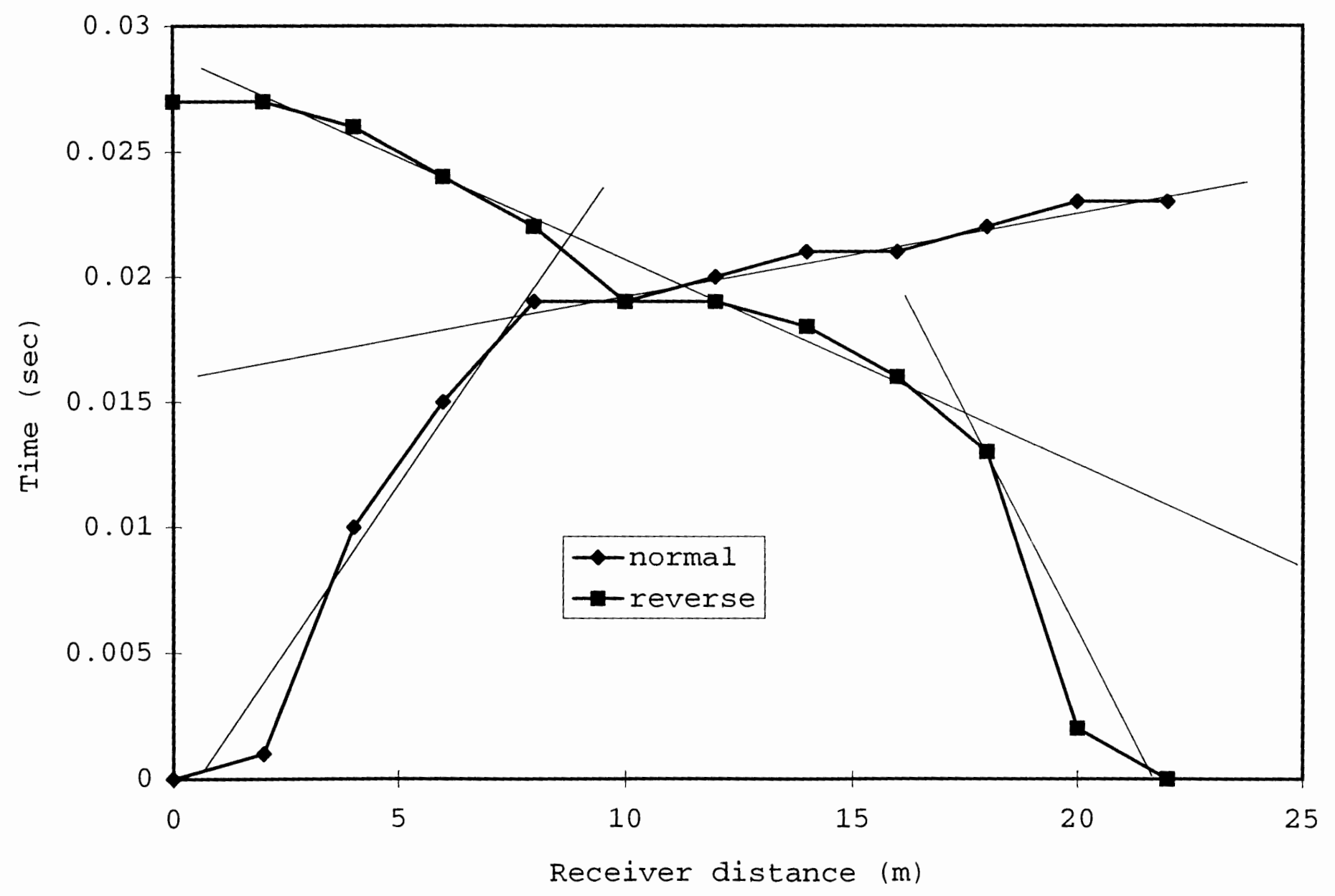




\section{Appendix 4}

Appendix 4 gives the stratigraphic columns for 25 sites located within the study area. Sites 1 through 9 were used for cross section construction (Figures 29 and 30). The locations of sites 1 through 9 are given in Figure 31. Sites 10 through 25 were not used in the cross sections of the study area. The locations of sites 10 through 25 are given in Appendix 4.

Elevations of the ground surface are given with the stratigraphic columns. Some sites have been surveyed and have established elevations. The elevations of the sites that have not been surveyed are approximated. The position in the stratigraphic columns where samples were taken for particle size analysis are shown adjacent to the stratigraphic columns. 


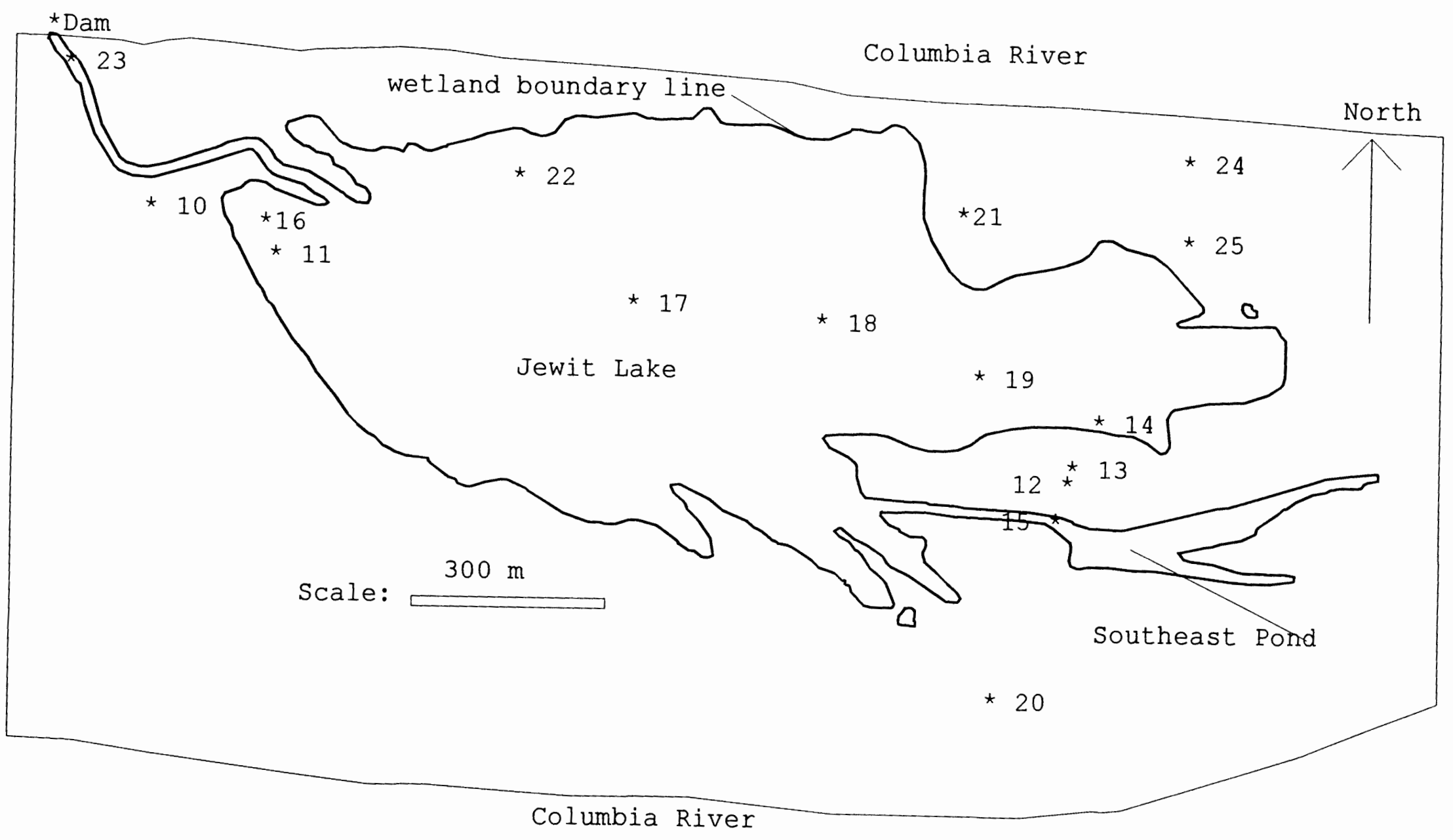

Figure 46 . Locations of stratigraphic columns that were not used for cross section 
$8.6 \mathrm{~m}$

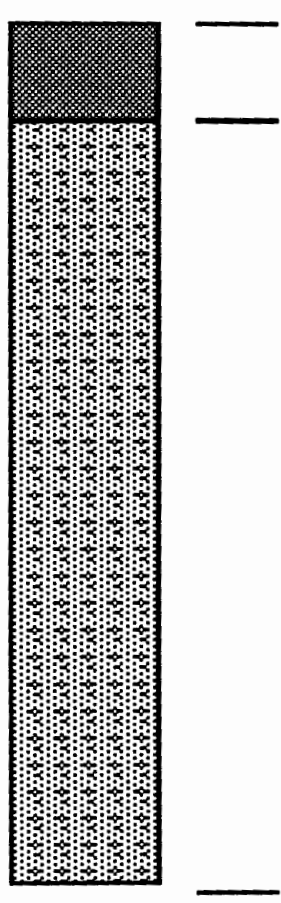

Stratigraphic Column \#1

0-20 cm: dark, organic rich silt

21-170 cm: silt with fine sand
$5.4 \mathrm{~m}$.

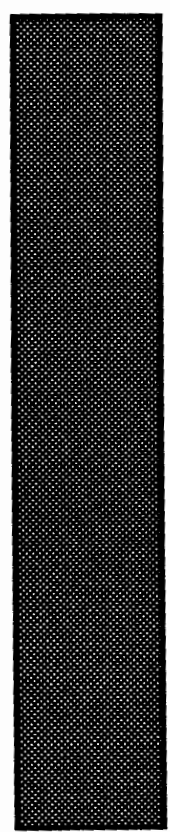

stratigraphic Column \# 2

0-160 cm: slightly mottled silt 
Stratigraphic column \#3

$3.6 \mathrm{~m}$
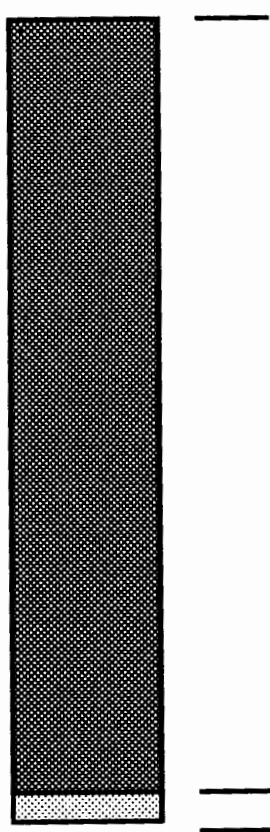

0-205 cm: muddy, organic rich, mottled silt collected hydrometer sample \# 12

— 205- cm.: medium sand, highly gleyed

Stratigraphic column \# 4

$4.0 \mathrm{~m}$

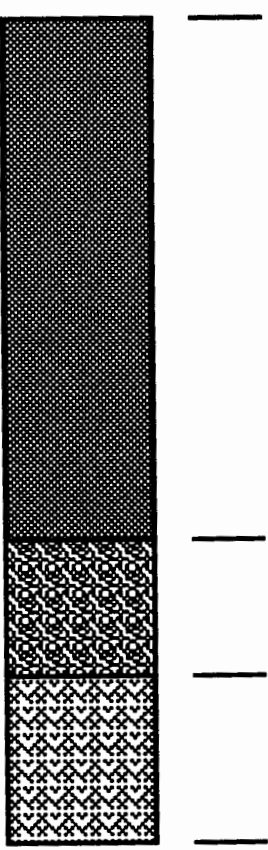

0-140 cm: dark, organic rich, mottled silt

141-170 cm: gray silt, highly gleyed collected hydrometer sample 11

170-195 cm: tan silt/clay 
Stratigraphic column \# 5

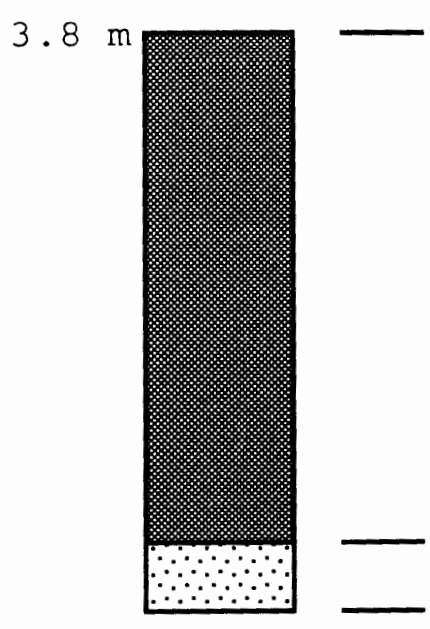

$$
\begin{aligned}
0-140 \mathrm{~cm}: & \text { dark, organic rich } \\
& \text { silt/clay collected } \\
& \text { hydrometer sample } 2
\end{aligned}
$$

$140 \mathrm{~cm}-:$ medium sand

Stratigraphic column \# 6

$7.4 \mathrm{~m}$

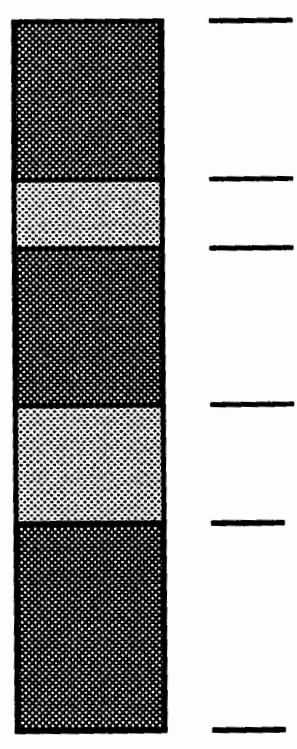

$0-36 \mathrm{~cm}$ : organic rich silt

37-52 cm: tan, mottled silt and fine sand

53-90 cm: organic rich silt, highly mottled $75-90 \mathrm{~cm}$.

90-115 cm: fine sand and silt

$115 \mathrm{~cm}-$ : organic rich silt 
Stratigraphic Column \# 7

4. $0 \mathrm{~m}$

0-110 cm: dark, organic rich silt

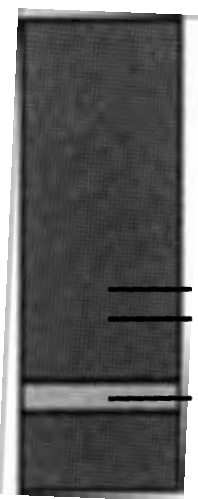

111-116 cm: Eine-medium sand

117- : organic rich silt

Stratigraphic Column \#8

$4.8 \mathrm{~m}$

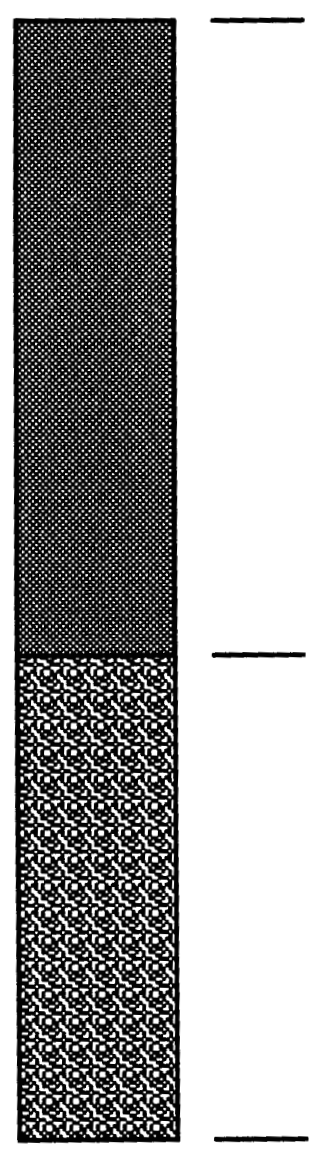

0-170 cm: organic rich silt

171-250 cm: Eine sand and silt, highly gleyed 
Stratigraphic Column \# 9

$6.1 \mathrm{~m}$

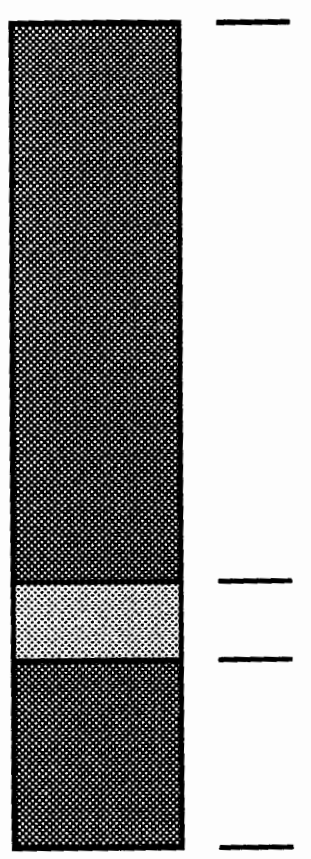

0-120 cm: dark, organic rich silt

121-145 cm: fine sand and silt

146-180 cm: mottled silt,

gleyed $170-180 \mathrm{~cm}$ 
Stratigraphic column \# 10

$4.1 \mathrm{~m}$

0-54 cm: dark, organic rich silt

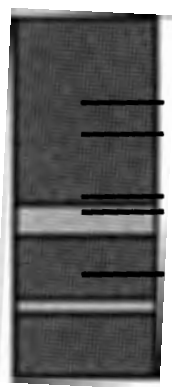

54-66 cm: mottled fine sand

66-83 cm: mottled, organic rich silt

83-88 cm: mottled fine sand

88-108 cm: mottled, organic rich silt

Stratigraphic Column \# 11

$4.0 \mathrm{~m}$

$0-33 \mathrm{~cm}$ : organic rich silt

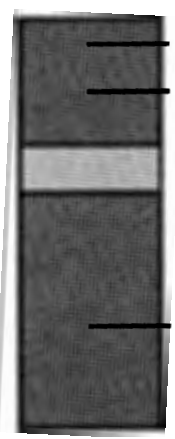

33-42 cm: mottled fine sand

42-?: mottled, organic rich silt collected hydrometer sample \# 5

Stratigraphic Column \# 12

$5.8 \mathrm{~m}$

$0-62 \mathrm{~cm}$ : unmottled silt

$62-77 \mathrm{~cm}$ : fine sand

77-101 cm: slightly mottled silt 
Stratigraphic column \# 13

$7.6 \mathrm{~m}$

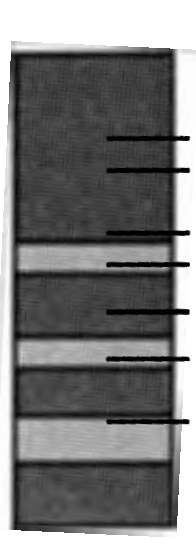

$0-56 \mathrm{~cm}$ : unmottled silt

56-65 cm: fine sand and silt

65-77 cm: unmottled silt

77-85 cm: fine sand and silt

85-94 cm: unmottled silt

94-104 cm: slightly mottled fine sand

104-? cm: slightly mottled silt

collected hydrometer sample \#6

Stratigraphic Column \# 14

$4.4 \mathrm{~m}$

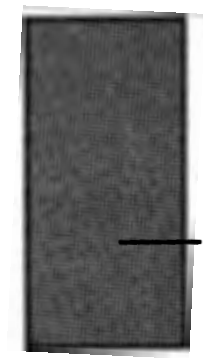

0-70 cm: dark, organic rich silt collected hydrometer sample \# 7

$4.1 \mathrm{~m}$

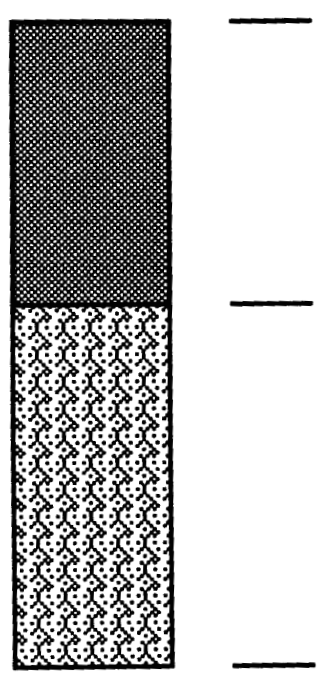

Stratigraphic column \# 15

$0-125 \mathrm{~cm}:$ silt

125-270 cm: poorly sorted coarse sand and gravel 
Stratigraphic Column \# 16

$4.2 \mathrm{~m}$

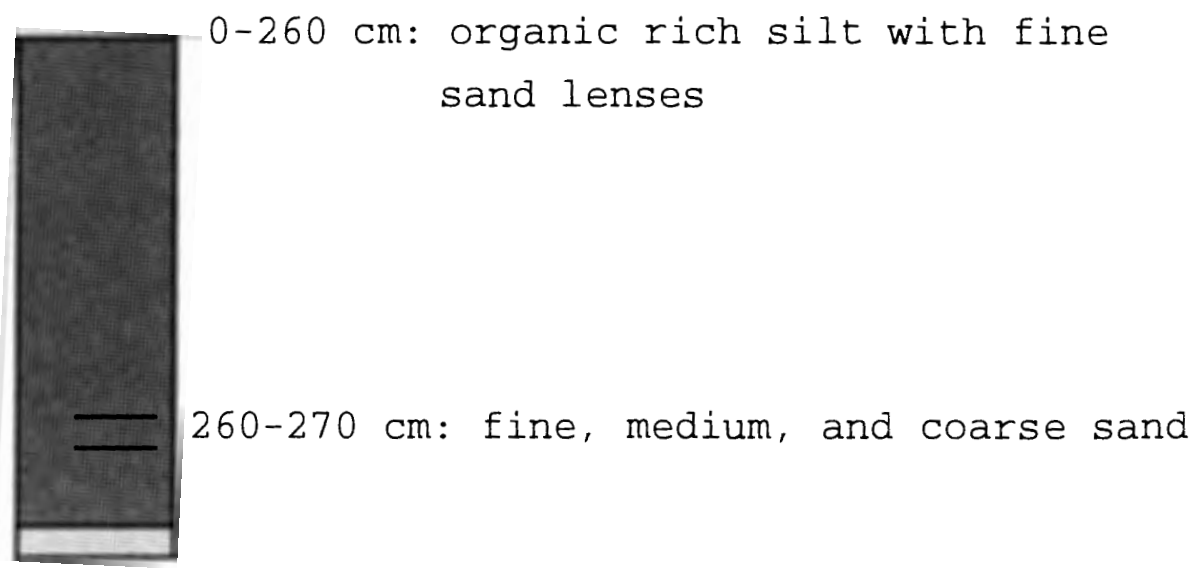

Stratigraphic column \# 17

$3.5 \mathrm{~m}$

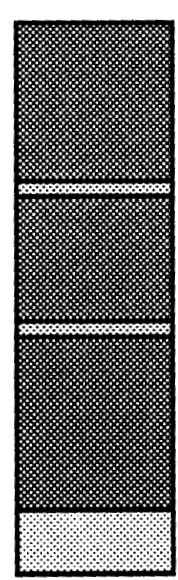

$-$

$0-30 \mathrm{~cm}$ : mottled organic rich silt

$=30-33 \mathrm{~cm}$ : fine sand

33-70 cm: mottled organic rich silt

$=70-77 \mathrm{~cm}$ : fine sand

77-118 cm: mottled organic rich silt with gleying increasing with depth 118-130 cm: medium sand 
Stratigraphic column \# 18

$3.5 \mathrm{~m}$

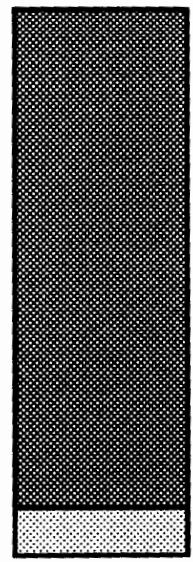

$-$

0-205 cm: organic rich silt,

highly gleyed at $180 \mathrm{~cm}$

depth. Collected

hydrometer sample 14

205-210 cm: well sorted medium sand

$3.6 \mathrm{~m}$

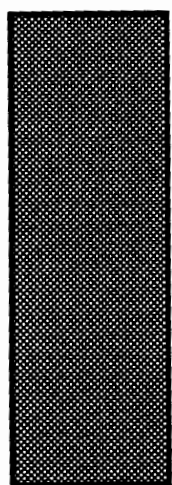

Stratigraphic column \#19

0-180 cm: organic rich silt

Stratigraphic column \#20

$4.6 \mathrm{~m}$
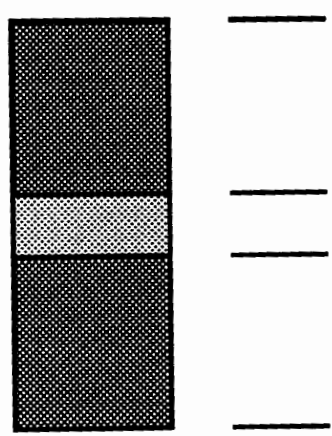

0-60 cm: slightly mottled organic rich silt

61-76 cm: slightly mottled fine and medium sand

76-103 cm: mottled organic rich silt collected hydrometer sample \# 3 
Stratigraphic column \# 21

$3.7 \mathrm{~m}$

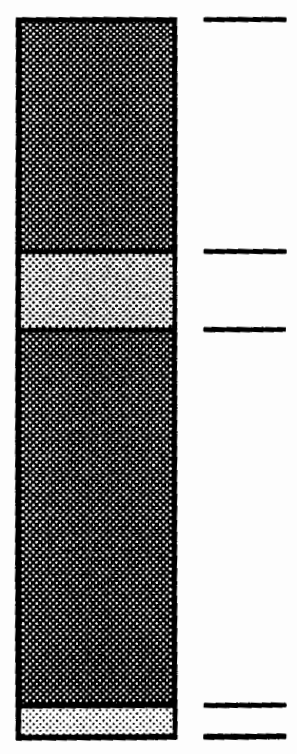

0-120 cm: organic rich silt

120-? cm: slightly gleyed fine sand

?-320 cm: mottled, organic rich silt below $240 \mathrm{~cm}$, strong

gleying is present

$320-325 \mathrm{~cm}:$ sand

Stratigraphic column \# 22

$4.0 \mathrm{~m}$

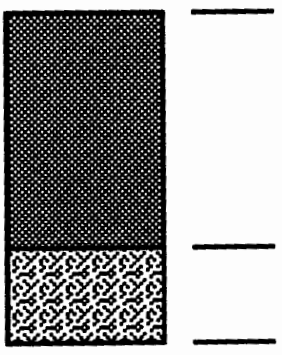

0 to 90-110 cm: mottled, organic rich silt

90-110 cm to ?: gleyed, organic rich silt and clay

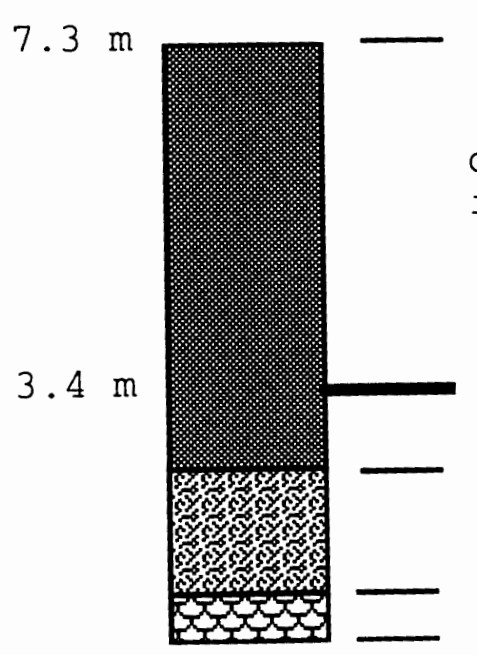

Stratigraphic column \#23

dark, organic rich silt. Mottling increases with depth

ground surface in the spillway channel

25-73 cm: gleyed, organic rich silt and clay

73-85 cm: tan silt and clay 
Stratigraphic column \# 24

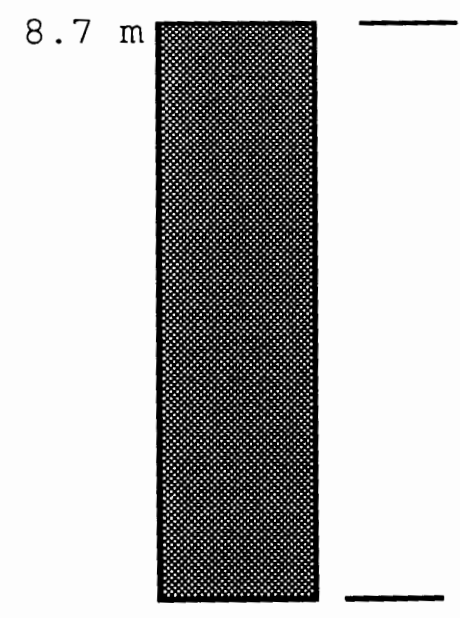
0-280 cm: organic rich silt with fine sand

Stratigraphic Column \# 25

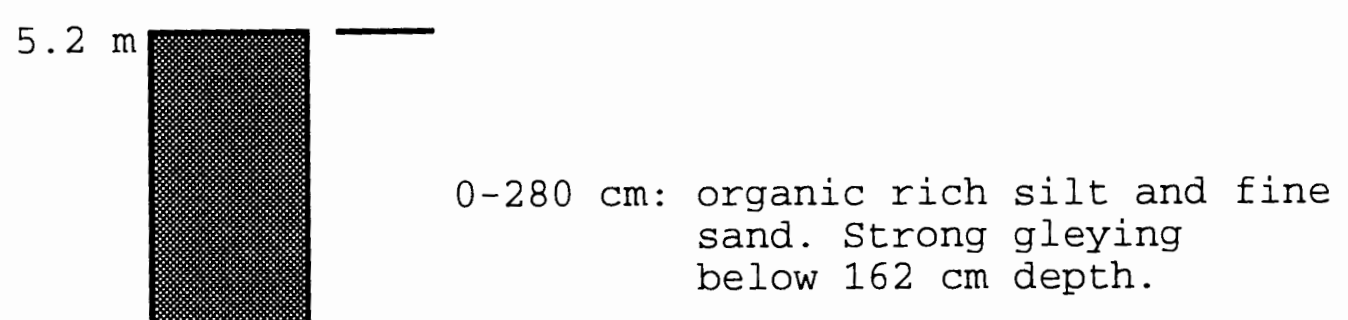

